EVALUATION OF INVERTEBRATE BIOACCUMULATION OF FLY ASH CONTAMINANTS IN THE EMORY, CLINCH, AND TENNEESSEE RIVERS, 2009 - 2010

\section{" OAK \\ RIDGE}
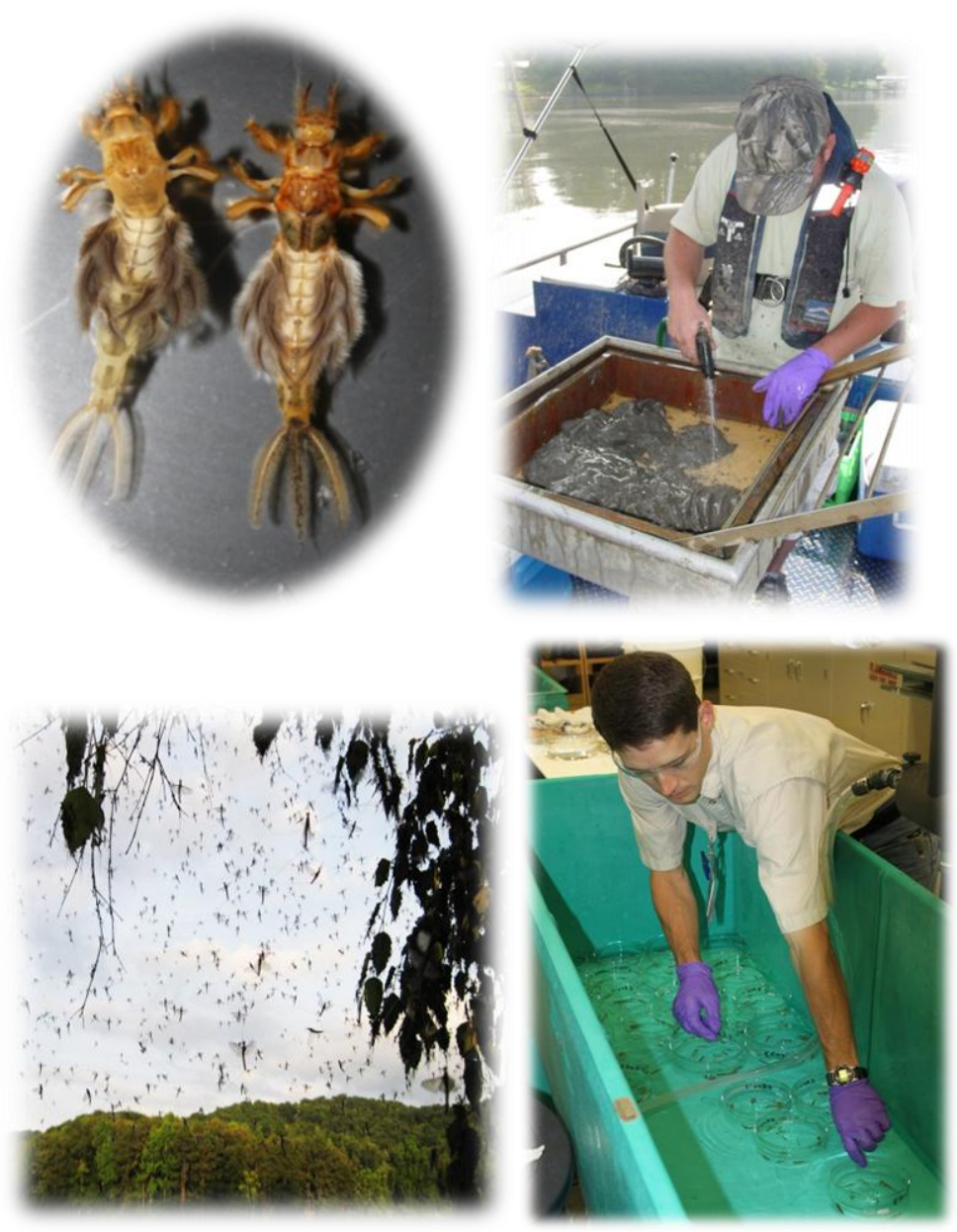

John G. Smith

May 2012 


\section{DOCUMENT AVAILABILITY}

Reports produced after January 1, 1996, are generally available free via the U.S. Department of Energy (DOE) Information Bridge.

Web site http://www.osti.gov/bridge

Reports produced before January 1, 1996, may be purchased by members of the public from the following source.

National Technical Information Service

5285 Port Royal Road

Springfield, VA 22161

Telephone 703-605-6000 (1-800-553-6847)

TDD 703-487-4639

Fax 703-605-6900

E-mail info@ntis.fedworld.gov

Web site http://www.ntis.gov/support/ordernowabout.htm

Reports are available to DOE employees, DOE contractors, Energy Technology Data Exchange (ETDE) representatives, and International Nuclear Information System (INIS) representatives from the following source.

Office of Scientific and Technical Information

P.O. Box 62

Oak Ridge, TN 37831

Telephone 865-576-8401

Fax 865-576-5728

E-mail reports@adonis.osti.gov

Web site http://www.osti.gov/contact.html

This report was prepared as an account of work sponsored by an agency of the United States Government. Neither the United States Government nor any agency thereof, nor any of their employees, makes any warranty, express or implied, or assumes any legal liability or responsibility for the accuracy, completeness, or usefulness of any information, apparatus, product, or process disclosed, or represents that its use would not infringe privately owned rights. Reference herein to any specific commercial product, process, or service by trade name, trademark, manufacturer, or otherwise, does not necessarily constitute or imply its endorsement, recommendation, or favoring by the United States Government or any agency thereof. The views and opinions of authors expressed herein do not necessarily state or reflect those of the United States Government or any agency thereof. 


\title{
EVALUATION OF INVERTEBRATE BIOACCUMULATION OF FLY ASH CONTAMINANTS IN THE EMORY, CLINCH, AND TENNEESSEE RIVERS, $2009-2010$
}

\author{
John G. Smith
}

May 2012

\author{
Prepared for: \\ Tennessee Valley Authority \\ Research and Technology Application \\ Knoxville, Tennessee \\ Prepared by: \\ Environmental Sciences Division \\ Oak Ridge National Laboratory \\ Oak Ridge, Tennessee 37831 \\ managed by \\ UT Battelle, LLC \\ for the \\ U.S. Department of Energy \\ under Contract DE-AC05-00OR22725
}


[THIS PAGE LEFT BLANK INTENTIONALLY] 


\section{CONTENTS}

Page

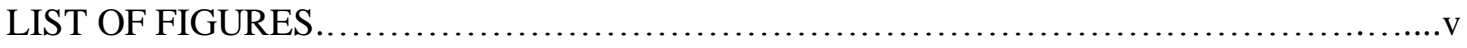

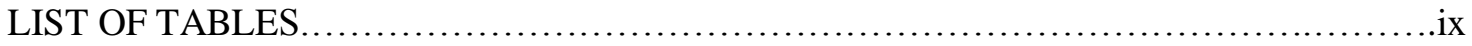

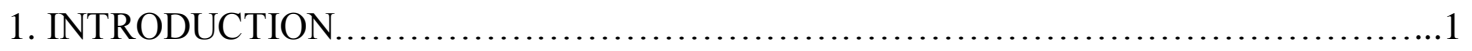

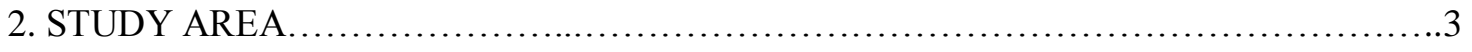

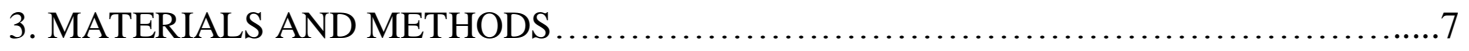

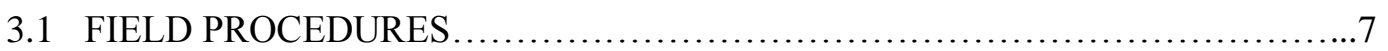

3.2 LABORATORY PROCEDURES ......................................... 8

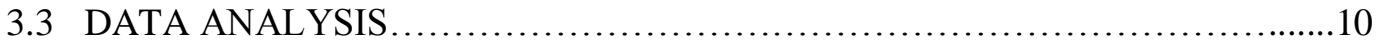

3.3.1 Principal Components Analysis..................................10

3.3.2 Analysis of Individual Elements................................12

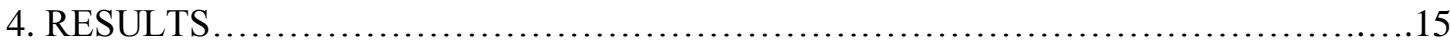

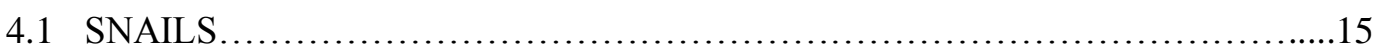

4.1.1 Principal Components Analysis................................15

4.1.2 Element-Specific Results..................................15

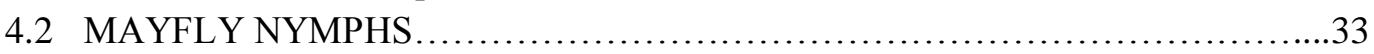

4.2.1 Principal Component Analysis..................................... 33

4.2.2 Element-Specific Results......................................34

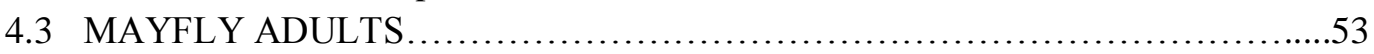

4.3.1 Principal Components Analysis................................53

4.3.2 Element-Specific Results.......................................59

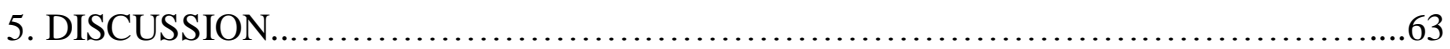

5.1 ASSESSMENT OF GROUP/SPECIES DIFFERENCES IN CONTAMINANT CONCENTRATIONS .......................................................

5.2 IDENTIFICATION OF ELEMENT SOURCE................................64

5.2.1 Element-Specific Discussion....................................65

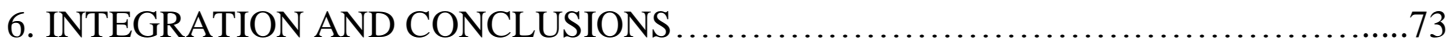

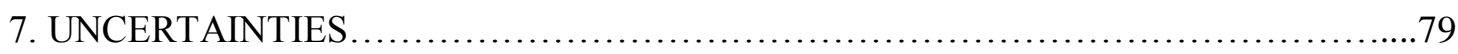

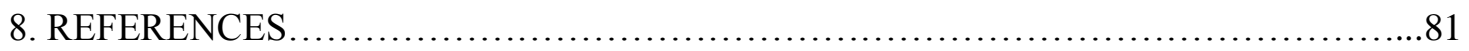

APPENDIX A. Mean Concentrations of Elements in Snails ...........................A-1

APPENDIX B. Mean Concentrations of Elements in Mayfly Nymphs.................. 1

APPENDIX C. Mean Concentrations of Elements in Adult Mayflies .................. -1 
[THIS PAGE LEFT BLANK INTENTIONALLY] 


\section{LIST OF FIGURES}

Page

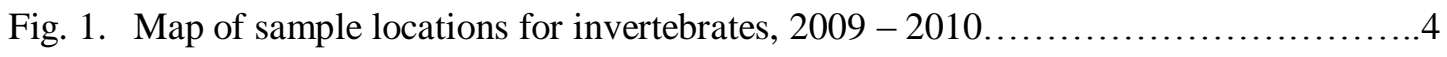

Fig. 2. Principal components analysis plots for snail bioaccumulation results in 2009 and 2010.

Fig. 3. Mean concentrations of arsenic (top) and selenium (bottom) in snails (Pleurocera canaliculatum) from sites in the Emory River, Clinch River, Tennessee River, and Little Emory River, 2009-2010..

Fig. 4. Mean concentrations of barium (top) and boron (bottom) in snails (Pleurocera canaliculatum) from sites in the Emory River, Clinch River, Tennessee River, and Little Emory River, 2009-2010.

Fig. 5. Mean concentrations of cadmium (top) and chromium (bottom) in snails (Pleurocera canaliculatum) from sites in the Emory River, Clinch River, Tennessee River, and Little Emory River, 2009-2010. .20

Fig. 6. Mean concentrations of cobalt (top) and copper (bottom) in snails (Pleurocera canaliculatum) from sites in the Emory River, Clinch River, Tennessee River, and Little Emory River, 2009-2010.

Fig. 7. Mean concentrations of lead (top) and mercury (bottom) in snails (Pleurocera canaliculatum) from sites in the Emory River, Clinch River, Tennessee River, and Little Emory River, 2009-2010. .22

Fig. 8. Mean concentrations of nickel (top) and zinc (bottom) in snails (Pleurocera canaliculatum) from sites in the Emory River, Clinch River, Tennessee River, and Little Emory River, 2009-2010. .23

Fig. 9. Mean concentrations of silver (top) and strontium (bottom) in snails (Pleurocera canaliculatum) from sites in the Emory River, Clinch River, Tennessee River, and Little Emory River, 2009-2010. .24

Fig. 10. Mean concentrations of vanadium (top) and thallium (bottom) in snails (Pleurocera canaliculatum) from sites in the Emory River, Clinch River, Tennessee River, and Little Emory River, 2009-2010.

Values are means $\pm 1 \mathrm{SE}$.

Fig. 11. Mean concentrations of aluminum (top) and molybdenum (bottom) in snails (Pleurocera canaliculatum) from sites in the Emory River, Clinch River, Tennessee River, and Little Emory River, 2009-2010.

Fig. 12. Mean concentrations of iron (top) and manganese (bottom) in snails (Pleurocera canaliculatum) from sites in the Emory River, Clinch River, Tennessee River, and Little Emory River, 2009-2010.

Values are means $\pm 1 \mathrm{SE}$. .27 


\section{LIST OF FIGURES (cont'd)}

Page

Fig. 13. Mean concentrations of calcium (top) and magnesium (bottom) in snails (Pleurocera canaliculatum) from sites in the Emory River, Clinch River, Tennessee River, and Little Emory River, 2009-2010.

Values are means $\pm 1 \mathrm{SE}$.

Fig. 14. Mean concentrations of potassium (top) and sodium (bottom) in snails (Pleurocera canaliculatum) from sites in the Emory River, Clinch River, Tennessee River, and Little Emory River, 2009-2010.

Values are means $\pm 1 \mathrm{SE}$.

Fig. 15. Principal components analysis plots for mayfly nymph bioaccumulation results in 2009 and 2010.

Fig. 16. Mean concentrations of aluminum (top) and antimony (bottom) in mayfly nymphs (Hexagenia bilineata) from sites in the Emory River, Clinch River, Tennessee River, and Little Emory River, 2009-2010.

Fig. 17. Mean concentration of arsenic in mayfly nymphs (top), mayfly adult female subimagos (middle) and mayfly adult male imagos (bottom) (Hexagenia bilineata) from sites in the Emory River, Clinch River, Tennessee River, and Little Emory River, 2009-2010.

Fig. 18. Mean concentration of barium in mayfly nymphs (top), mayfly adult female subimagos (middle) and mayfly adult male imagos (bottom) (Hexagenia bilineata) from sites in the Emory River, Clinch River, Tennessee River, and Little Emory River, 2009-2010

Fig. 19. Mean concentrations of boron (top), chromium (middle), and nickel (bottom) in mayfly nymphs (Hexagenia bilineata) from sites in the Emory River, Clinch River,

Tennessee River, and Little Emory River, 2009-2010.

Fig. 20. Mean concentration of cadmium in mayfly nymphs (top) and mayfly adult male imagos (bottom) (Hexagenia bilineata) from sites in the Emory River, Clinch River, Tennessee River, and Little Emory River, 2009-2010.

Fig. 21. Mean concentration of cobalt in mayfly nymphs (top), and mean concentrations of copper in mayfly nymphs (middle) and mayfly adult male imagos (bottom) (Hexagenia bilineata) from sites in the Emory River, Clinch River, Tennessee River, and Little Emory River, 2009-2010.

Fig. 22. Mean concentrations of iron (top), lead (middle), and manganese (bottom) in mayfly nymphs (Hexagenia bilineata) from sites in the Emory River, Clinch River, Tennessee River, and Little Emory River, 2009-2010

Fig. 23. Mean concentration of mercury in mayfly nymphs (top) and mayfly adult male imagos (bottom) (Hexagenia bilineata) from sites in the Emory River, Clinch River, Tennessee River, and Little Emory River, 2009-2010. 


\section{LIST OF FIGURES (cont'd)}

Page

Fig. 24. Mean concentration of molybdenum in mayfly nymphs (top), mayfly adult female subimagos (middle) and mayfly adult male imagos (bottom) (Hexagenia bilineata) from sites in the Emory River, Clinch River, Tennessee River, and Little Emory River, 2009-2010.

Fig. 25. Mean concentration of selenium in mayfly nymphs (top), mayfly adult female subimagos (middle) and mayfly adult male imagos (bottom) (Hexagenia bilineata) from sites in the Emory River, Clinch River, Tennessee River, and Little Emory

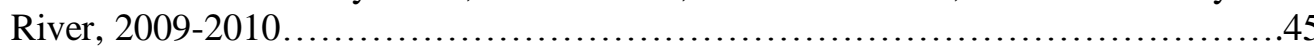

Fig. 26. Mean concentration of silver in mayfly nymphs (top) and mayfly adult male imagos (bottom) (Hexagenia bilineata) from sites in the Emory River,

Clinch River, Tennessee River, and Little Emory River, 2009-2010. .46

Fig. 27. Mean concentration of strontium in mayfly nymphs (top), mayfly adult female subimagos (middle) and mayfly adult male imagos (bottom) (Hexagenia bilineata) from sites in the Emory River, Clinch River, Tennessee River, and Little Emory

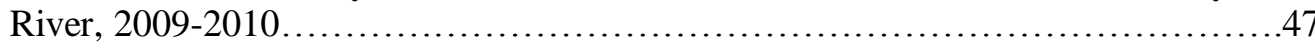

Fig. 28. Mean concentration of thallium in mayfly nymphs (top), and mean concentrations of vanadium in mayfly nymphs (middle) and mayfly adult male imagos (bottom) (Hexagenia bilineata) from sites in the Emory River, Clinch River, Tennessee River, and Little Emory River, 2009-2010.

Fig. 29. Mean concentration of zinc in mayfly nymphs (top), mayfly adult female subimagos (middle) and mayfly adult male imagos (bottom) (Hexagenia bilineata) from sites in the Emory River, Clinch River, Tennessee River, and Little Emory River, 2009-2010.

Fig. 30. Principal components analysis plots for adult mayfly bioaccumulation results in 2009 and 2010.

Fig. 31. Principal components analysis plots for comparisons of bioaccumulation results (2010 data only) for the subimago and imago stages of adult mayflies

Fig. 32. Principal components analysis plots for comparisons of bioaccumulation results (2010 data only) for female and male adult mayflies.... 
[THIS PAGE LEFT BLANK INTENTIONALLY] 


\section{LIST OF TABLES}

Page

Table 1. Groups of invertebrates analyzed for bioaccumulation of contaminants in 2009 and 2010.

Table 2. Summary of analysis of variance (ANOVA) models and site/group subsets used in the evaluation of elements assessed in the study of invertebrate bioaccumulation.

Table 3. Principal component analysis loadings (i.e., correlation coefficients which range from -1.0 to 1.0 ) for elements in snails.

Table 4. Summary results for ANOVAs performed on individual elements in snails.

Table 5. Principal component analysis loadings (i.e., correlation coefficients which range from -1.0 to 1.0 ) for elements in mayfly nymphs....

Table 6. Summary results for ANOVAs performed on individual elements in mayfly nymphs

Table 7. Principal component analysis loadings (i.e., correlation coefficients which range from -1.0 to 1.0) for elements in adult mayflies.

Table 8. Summary of two-way ANOVA results for analysis of effects of adult life stage (subimago versus imago) and sex (female versus male) on element concentrations

Table 9. Summary results for ANOVAs performed on individual elements in adult mayflies.

Table 10. Summary of invertebrate groups with the maximum concentration for each element.

Table 11. Sites and invertebrate groups where maximum mean concentrations of elements were found in 2009 and 2010

Table 12. Site frequencies for maximum concentrations for each invertebrate group in 2009 and 2010

Table 13. Summary matrix of potential sources of elements found to be elevated or potentially elevated in aquatic invertebrates. 
[THIS PAGE LEFT BLANK INTENTIONALLY] 


\section{INTRODUCTION}

This report provides a summary of results from studies on invertebrate bioaccumulation of potential contaminants associated with a major fly ash spill into the Emory River following the failure of a dike at the Tennessee Valley Authority's (TVA) Kingston Fossil Plant (KIF) in Kingston, Tennessee, in late December 2008. Data included in this report cover samples collected in calendar years 2009 and 2010.

Samples collected from most sites in 2009 were processed by two different laboratories using different approved U.S. Environmental Protection Agency (EPA) analytical methods: ALS Laboratory Group in Ft. Collins, CO, processed sampling using EPA method 6010 (but method 6020 for uranium and SW7470 for mercury), and PACE Analytical in Minneapolis, MN, used EPA method 6020. A preliminary evaluation of results from both laboratories indicated that some differences exited in measured concentrations of several elements, either because of specific differences of the two methods or inter-laboratory differences. While concentration differences between the laboratories were noted for many elements, spatial trends depicted from the results of both methods appeared to be similar. However, because samples collected in the future will be analyzed by Method 6020, only the results from PACE were included in this report to reduce data variation potentially associated with inter-laboratory and analytical method differences. 
[THIS PAGE LEFT BLANK INTENTIONALLY] 


\section{STUDY AREA}

Five core sampling sites were initially selected in 2009 for collections of snails (Pleurocera canaliculatum) and mayflies (nymphs and adults of Hexagenia bilineata), including three on the Emory River (river mile 1.0 or ERM 1.0, ERM 2.5 and ERM 6.0) and two on the Clinch River (CRM 6.0 and CRM 1.5) (Fig. 1). When sampling began in 2009, multiple attempts to collect mayfly nymphs from the main river channel at ERM 6.0 were unsuccessful, most likely due to a dominance of sand and detritus in the substrate, which are not preferred substrate types of this species. Therefore, samples for this site were collected from a small slough located on the left descending side of the river near the mile 6 marker in the main channel. Clinch River site CRM 6.0 and Emory River site ERM 6.0 served as upstream reference sites for all three groups of invertebrates; a site on Little Emory River (LERM 1.0) also served as a reference for mayflies in 2009 and mayflies and snails in 2010. In 2010, additional sites were included in the study: ERM 4.0 on the Emory River, CRM 3.5 on the Clinch River, and TRM 560.8, TRM 566.3, and TRM 572.5 on the Tennessee River; the latter site served as a reference for the other Tennessee River sites (Fig. 1). A summary of sites included in this study and the invertebrate groups collected from each is provided in Table 1. 


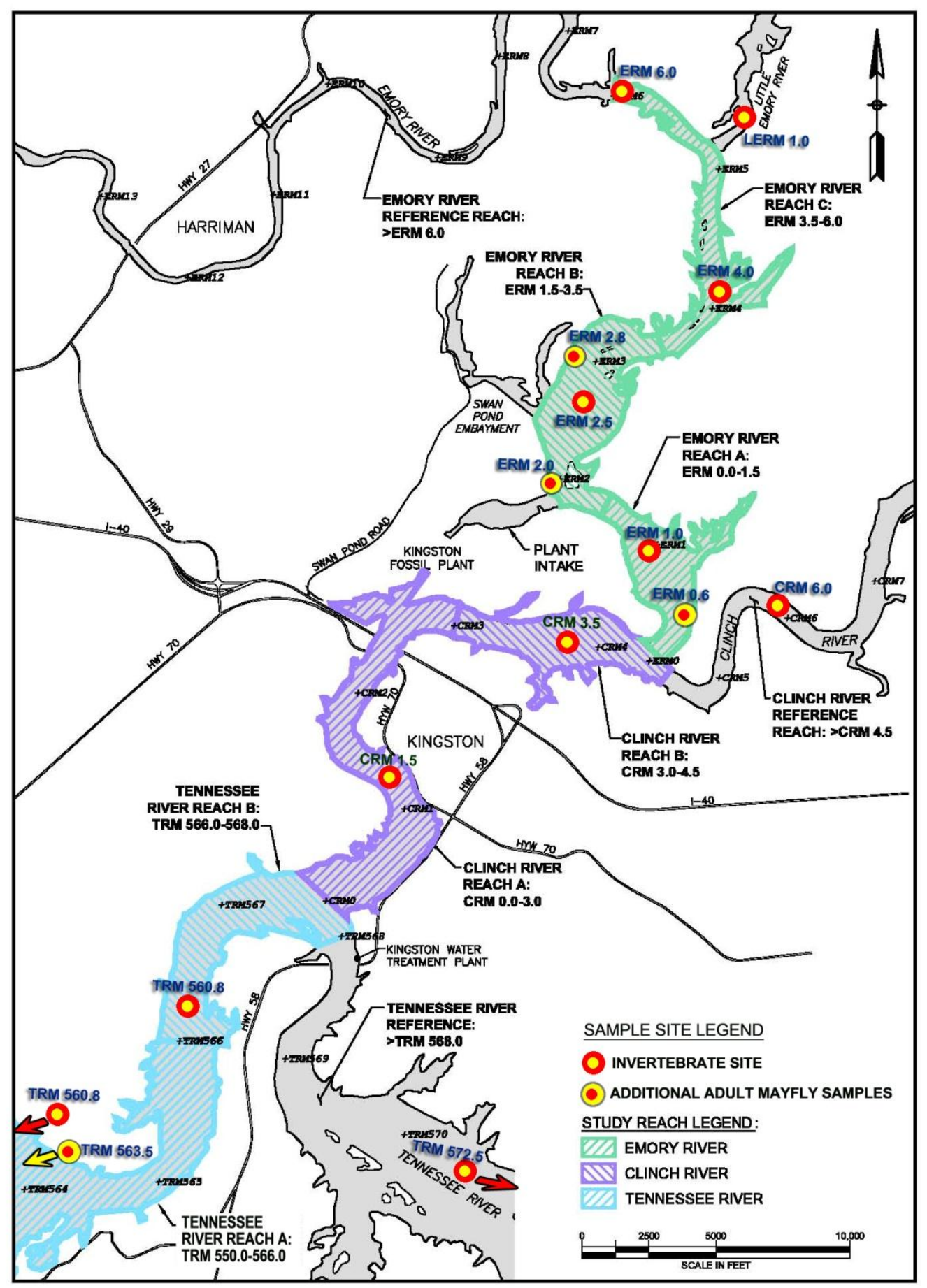

Fig. 1. Map of sample locations for invertebrates, $2009-2010$. 
Table 1. Groups of invertebrates analyzed for bioaccumulation of contaminants in 2009 and 2010. Due to close proximity, some locations where adult mayflies were collected were combined based on the results of a principal components analysis (see the Materials and Methods section). Additionally, some sites where adult mayflies were collected have been excluded if no more than one sample was available.

\begin{tabular}{|c|c|c|c|c|c|c|c|c|c|}
\hline \multirow[b]{3}{*}{ River/Site ${ }^{3}$} & \multirow[b]{3}{*}{ Year } & \multirow{2}{*}{\multicolumn{2}{|c|}{ Mayfly nymphs ${ }^{1,2}$}} & \multicolumn{4}{|c|}{ Mayfly adults ${ }^{2}$} & \multirow{2}{*}{\multicolumn{2}{|c|}{ Snails $^{1,2}$}} \\
\hline & & & & Subi & gos & $\operatorname{Im}$ & & & \\
\hline & & $\mathrm{D}$ & ND & Female & Male & Female & Male & $\mathrm{D}$ & ND \\
\hline \multicolumn{10}{|l|}{ Emory River } \\
\hline \multirow{2}{*}{ ERM 0.6} & 2009 & - & - & - & - & - & - & - & - \\
\hline & 2010 & - & - & $\mathrm{X}$ & $\mathrm{X}$ & - & $\mathrm{X}$ & - & - \\
\hline \multirow{2}{*}{ ERM $1.0^{4}$} & 2009 & $\mathrm{X}$ & $\mathrm{X}$ & - & - & - & $\mathrm{X}$ & $\mathrm{X}$ & - \\
\hline & 2010 & $\mathrm{X}$ & $\mathrm{X}$ & $\mathrm{X}$ & $\mathrm{X}$ & - & $\mathrm{X}$ & $\mathrm{X}$ & $\mathrm{X}$ \\
\hline \multirow{2}{*}{ ERM $2.5^{5}$} & 2009 & - & $\mathrm{X}$ & - & - & - & $\mathrm{X}$ & $\mathrm{X}$ & - \\
\hline & 2010 & $\mathrm{X}$ & $\mathrm{X}$ & $\mathrm{X}$ & $\mathrm{X}$ & $\mathrm{X}$ & $\mathrm{X}$ & $\mathrm{X}$ & $\mathrm{X}$ \\
\hline \multirow{2}{*}{ ERM 2.8} & 2009 & - & - & - & - & - & - & - & - \\
\hline & 2010 & - & - & - & - & $\mathrm{X}$ & $\mathrm{X}$ & - & - \\
\hline \multirow{2}{*}{ ERM $4.0^{6}$} & 2009 & - & - & - & - & - & $\mathrm{X}$ & - & - \\
\hline & 2010 & $\mathrm{X}$ & $\mathrm{X}$ & - & - & - & - & $\mathrm{X}$ & $\mathrm{X}$ \\
\hline \multirow{2}{*}{ ERM 6.0} & 2009 & - & $\mathrm{X}$ & - & - & - & - & $\mathrm{X}$ & - \\
\hline & 2010 & $\mathrm{X}$ & $\mathrm{X}$ & - & - & - & - & $\mathrm{X}$ & $\mathrm{X}$ \\
\hline \multicolumn{10}{|l|}{ Clinch River } \\
\hline \multirow{2}{*}{ CRM 1.5} & 2009 & $\mathrm{X}$ & $\mathrm{X}$ & - & - & $\mathrm{X}$ & $\mathrm{X}$ & $\mathrm{X}$ & - \\
\hline & 2010 & $\mathrm{X}$ & $\mathrm{X}$ & - & - & $\mathrm{X}$ & $\mathrm{X}$ & $\mathrm{X}$ & $\mathrm{X}$ \\
\hline \multirow{2}{*}{ CRM 3.5} & 2009 & - & - & - & - & - & - & - & - \\
\hline & 2010 & $\mathrm{X}$ & $\mathrm{X}$ & $\mathrm{X}$ & - & $\mathrm{X}$ & $\mathrm{X}$ & $\mathrm{X}$ & $\mathrm{X}$ \\
\hline \multirow{2}{*}{ CRM $6.0^{7}$} & 2009 & - & $\mathrm{X}$ & $\mathrm{X}$ & $\mathrm{X}$ & - & - & $\mathrm{X}$ & - \\
\hline & 2010 & $\mathrm{X}$ & $\mathrm{X}$ & - & - & - & $\mathrm{X}$ & $\mathrm{X}$ & $\mathrm{X}$ \\
\hline \multicolumn{10}{|c|}{ Tennessee River } \\
\hline \multirow{2}{*}{ TRM 560.8} & 2009 & - & - & - & - & - & - & - & - \\
\hline & 2010 & - & $\mathrm{X}$ & - & - & - & - & - & - \\
\hline \multirow{2}{*}{ TRM $563^{8}$} & 2009 & - & - & - & - & - & $\mathrm{X}$ & - & - \\
\hline & 2010 & - & - & $\mathrm{X}$ & $\mathrm{X}$ & - & $\mathrm{X}$ & - & - \\
\hline \multirow{2}{*}{ TRM 566.3} & 2009 & - & - & - & - & - & - & - & - \\
\hline & 2010 & $\mathrm{X}$ & $\mathrm{X}$ & - & - & - & - & $\mathrm{X}$ & - \\
\hline \multirow{2}{*}{ TRM $567^{9}$} & 2009 & - & - & $\mathrm{X}$ & $\mathrm{X}$ & $\mathrm{X}$ & $\mathrm{X}$ & - & - \\
\hline & 2010 & - & - & $\mathrm{X}$ & $\mathrm{X}$ & - & $\mathrm{X}$ & - & - \\
\hline \multirow{2}{*}{ TRM $572.5^{10}$} & 2009 & - & - & - & - & - & - & - & - \\
\hline & 2010 & $\mathrm{X}$ & $\mathrm{X}$ & $\mathrm{X}$ & $\mathrm{X}$ & - & $\mathrm{X}$ & $\mathrm{X}$ & - \\
\hline \multicolumn{10}{|c|}{ Little Emory River } \\
\hline \multirow{2}{*}{ LERM 1.0} & 2009 & - & $\mathrm{X}$ & - & - & $\mathrm{X}$ & $\mathrm{X}$ & - & - \\
\hline & 2010 & - & $\mathrm{X}$ & - & - & - & - & $\mathrm{X}$ & - \\
\hline
\end{tabular}

1,ND" = not depurated; "D" = depurated.

${ }^{2}$ Mayfly nymphs and adults = Hexagenia bilineata $;$ snails = Pleurocera canaliculatum .

${ }^{3}$ ERM = Emory River mile; CRM = Clinch River mile; TRM = Tennessee River mile; LERM = Little Emory River mile.

${ }^{4}$ For adult mayfly collections, this site is referred to as ERM 1 and consists of collections between $\sim$ ERM 0.8 and $\sim$ ERM 1.1 .

${ }^{5}$ For adult mayfly collections, this site is referred to as ERM 2 and consists of collections between ERM 1.8 and $\sim$ ERM 2.5 .

${ }^{6}$ For adult mayfly collections, ERM 4.0 consists of collections between ERM 3.9 and ERM 4.5.

${ }^{7}$ For adult mayfly collections, CRM 6.0 consists of collections between CRM 5.5 and CRM 6.2.

${ }^{8}$ For adult mayfly collections, TRM 563 consists of collections between TRM 562.0 and TRM 563.5.

${ }^{9}$ For adult mayfly collections, TRM 567 consists of collections between TRM 566.0 and TRM 567.6.

${ }^{10}$ For adult mayfly collections, TRM 572.5 is referred to as TRM 572 and consists of collections between TRM 571.0 and TRM 573.0. 
[THIS PAGE LEFT BLANK INTENTIONALLY] 


\section{MATERIALS AND METHODS}

\subsection{FIELD PROCEDURES}

Samples of snails and mayflies were collected from each location during one collection period each year. While collections of snails and mayfly nymphs were generally confined to a relatively narrow sampling period, due to the unpredictability in the timing and location of emerging adult mayflies, collections of this group generally extended over a longer period (i.e., mid-June through mid-August). With few exceptions, all collections of adults at a particular site were generally completed within a twoday period. Once adults had been collected from a site, further efforts in collections were generally focused on areas near sites where adults had not yet been collected, although in some cases, multiple collections were made at some sites; in these cases, samples from the different dates were composited.

Snails were collected by hand from submerged gravels, rocks, and various other solid, stable structures along the shoreline at each between mid-June and early-September in both years, although most collections were completed in July. Samples of snails were collected at each site from four and three distinct locations (referred to as transects) in 2009 and 2010, respectively; transects were $\sim 50 \mathrm{~m}$ to $250 \mathrm{~m}$ apart. Approximately 35 snails were collected from each transect for depuration prior to analysis (see Section 3.2 below), and in 2010, 25 additional snails were collected from each transect at a subset of sites (Table 1) for analysis without depuration. To account for occasional mortality, more snails were needed for depurated samples to ensure that enough tissue was available for analysis. After snails were collected from a transect, they were placed in pre-labeled 16-oz or 32-oz clean glass sample bottles filled with water from the site, and then stored on ice in a cooler for transport back to the laboratory.

Mayfly nymphs were collected from each site with a Peterson dredge across 3 (2010) or 4 (2009) transects perpendicular to the river channel. The contents of the dredge were emptied onto a large sieve with a $1 \mathrm{~mm}$ nylon-mesh, and then rinsed with water from the site to remove fine sediment particles and reveal the nymphs. Nymphs were removed from the sample with stainless steel forceps and held temporarily in a small clean plastic container filled with water from the site; 80-120 nymphs were collected from each transect. Nymphs collected for pre-analysis depuration were transferred to a clean sample bottle filled with water from the site, and then placed on ice in a cooler for transport back to the laboratory. Nymphs collected for analysis without depuration were placed in a 2-4 oz glass sample bottle and held on ice for transport back to the laboratory.

Adult mayflies were collected opportunistically with a sweep net from vegetation along the shoreline, transferred to $32 \mathrm{oz}$ glass sample bottles, and stored on ice for transport to the laboratory. The adults of Hexagenia species generally emerge in large masses at multiple locations within the same watershed. This was generally the case in both 2009 and 2010 in this study; therefore, samples from many sites were collected during the same 2 to 3 day period. Efforts were made in both years to collect adult mayflies from all core sampling locations (see Section 2 above), but because of the uncertainty and unpredictability in the timing and location of their emergence, samples had to be collected opportunistically wherever they were available (Fig. 1, Table 1). As a consequence, samples were not collected from all core sites in either year, nor were samples collected from all of the same locations in both years. 


\subsection{LABORATORY PROCEDURES}

With only one exception noted below in the Data Analysis section, all results included in this report are based samples that were analyzed by PACE Analytical Services by ICP/MS following EPA Method 6020a (http://www.epa.gov/epawaste/hazard/testmethods/sw846/pdfs/6020a.pdf). Twenty-six elements potentially associated with fly ash were included in the analysis.

Processing of snails began immediately upon return from the field. The sample bottles with snails to be depurated were removed from the cooler and set in a water bath for at least $1 \mathrm{hr}$ to begin acclimation to the laboratory temperatures; a temperature difference of $\sim 5^{\circ} \mathrm{C}$ between the water used to rinse the snails and the water bath appeared to have no noticeable effect on survival during depuration (see below). Snails that were not depurated required no thermal acclimation. Within $2 \mathrm{hr}$ after returning from the field, all snails were scrubbed with a small, stiff nylon brush to remove debris from the exterior of the shell (e.g., periphyton, clay and silt particles). This was to ensure that the periphyton and other particles attached to the shell would not inadvertently become part of the sample during tissue extraction. It also ensured that snails undergoing depuration would not have access to a source of food during depuration. Scrubbing was followed by a triple rinse with distilled water. All snails collected in 2009 were depurated ( $72 \mathrm{hr}$ depuration period) in the laboratory prior to analysis, while in 2010 both depurated (all sites) and non-depurated (subset of sites) snails were analyzed (Table 1). Snails that were not depurated were placed into pre-labeled, clean sample bottles after being cleaned and stored in a freezer until further processing. During depuration, snails were put in glass crystallizing dishes that were partially filled with distilled water, and then held in a shallow flow-through water bath maintained at a relatively constant temperature $\left(\sim 20-23^{\circ} \mathrm{C}\right)$. Every $12 \mathrm{hr}$ during depuration, the dishes were rinsed with distilled water, dead snails were removed and disposed of, and fresh distilled water was added. At the end of the depuration period ( $72 \mathrm{hr}$ ), the snails were placed in clean, pre-labeled sample bottles and stored in a freezer until further processed.

Prior to tissue extraction, snail samples were removed from the freezer and allowed to thaw. To remove the tissue, the shell was cut along the spire's edge with small stainless steel cutters starting at the juncture of the outer lip and the aperture until the muscle attaching the body to the shell was reached. The muscle was then detached from the shell, and all tissue was removed and placed in a tared $40 \mathrm{~mL}$ sample bottle that was placed on the pan of an analytical balance (Mettler AE240 balance). Tissue from more snails was added until the desired biomass was reached, and then the cap of the bottle was replaced before storing the sample in a freezer. After tissue extraction from all snail samples was complete, the samples were removed from the freezer and dried to a constant weight ( $\geq 72 \mathrm{hr})$ in a freeze drier. The average wet weight for snail samples in 2009 was slightly more than $5.0 \mathrm{gm}$, and in 2010 the average sample weight was $\sim 3.0 \mathrm{gm}$.

Processing of mayfly nymphs began immediately upon return from the field. The initial procedures for handling mayfly nymphs collected for depuration were slightly different than those for nymphs that would not be depurated. Initially, nymphs collected for depuration were kept in sample bottles and set in a shallow water bath to allow some acclimation to laboratory temperatures. As observed with snails, a temperature difference of $\sim 5^{\circ} \mathrm{C}$ between the rinse water and the water bath appeared to have no noticeable effect on survival during depuration. After $\sim 1$ to $2 \mathrm{hr}$ of acclimation, the nymphs were triple rinsed with distilled water to remove attached particles of silt and detritus before beginning 
depuration. Other than the amount of time allowed for depuration (48 $\mathrm{hr}$ for nymphs), the procedures followed for depurating nymphs were similar to those used for snails. At the end of the depuration period, the nymphs were rinsed a final time with distilled water before being placed in clean 4-oz, prelabeled glass sample bottle and stored in the freezer until further processing. Samples of nymphs collected that were not depurated were triple rinsed with distilled water, placed in 4-oz clean, pre-labeled glass sample bottles, and stored in a freezer until further processed. In 2009, samples of non-depurated nymphs were submitted for analysis from all sites, while samples of depurated nymphs from only two sites were analyzed (Table 1). In 2010, non-depurated nymphs from all sites and depurated nymphs from nine sites were analyzed (Table 1).

Before final processing, nymph samples were removed from the freezer and allowed to thaw. When thawing was complete, nymphs were placed briefly ( $\leq 2$ minutes) on a clean Kimwipe ${ }^{\circledR}$ to remove excess external moisture. Individuals were added to a tared $40 \mathrm{~mL}$ glass bottle on an analytical balance until the desired mass was obtained. After the desired mass was obtained, the nymph samples were refrozen and freeze dried following the same procedures for snails. In 2009, the average wet weight per sample of nymphs was $\sim 3.3$ gm, and in 2010 , the average sample weight was $\sim 2$ gm.

Samples of adult mayflies were initially placed in a freezer in the laboratory on the same day as they were collected. Before processing the samples, they were removed from the freezer and allowed to thaw. Small aliquots of mayflies were then placed in a large, acid-washed plastic dish and sorted by sex and adult stage (i.e., by subimago and imago) for analysis. This was repeated with additional aliquots until a sufficient number of mayflies had been sorted to provide the amount of biomass needed for analysis (i.e., $<1.7 \mathrm{gm}$ wet weight). This provided up to 4 possible subgroups of adult mayflies for analysis at a given site: male subimagos, female subimagos, male imagos, and female imagos. While every effort was made to collect representatives from all four subgroups at as many sites as possible, many collections included only one or two of the groups (most common was male imagos, most common site-pairs were male and female subimagos), and there were only two sites where enough sample material was collected for analysis of all four groups (ERM 2 in 2010 and TRM 567 in 2009).

Because adult mayflies generally congregate (or swarm) in relatively small areas, all the mayflies collected from a site had to be divided to create the desired number of replicates (2009, 4 replicates; 2010, 3 replicates). However, the mayflies comprising these swarms can come from a relatively large area in the vicinity of the swarm. Thus, for example, adult mayflies collected at ERM 1.0 most likely come water immediately adjacent to the mating swarm, but they also may have come from as far away as 500 m. After groups from a site were sorted, replicates were created for each available subgroup. For each replicate, individuals were added to a tared $40 \mathrm{~mL}$ glass bottle on an analytical balance until the desired mass was obtained. After the desired biomass was obtained, the same procedures followed for refreezing and freeze drying snails and nymphs were also followed for adult mayflies. In 2009, the average wet weight of each sample of adult mayflies was $\sim 4.5 \mathrm{gm}$, and in 2010, the average sample weight for nymphs was $\sim 2.5 \mathrm{gm}$. 


\subsection{DATA ANALYSIS}

A combination of multivariate and univariate statistical analysis methods was used to analyze invertebrate bioaccumulation data. Multivariate analysis helped in visualization of site, time, and subgroup (e.g., depurated versus non-depurated snails, males versus female mayflies) trends, and it helped identify the elements that contributed most strongly to the observed trends. Univariate analyses were then used for evaluating the magnitude of differences of the individual elements among factors (i.e., collection years, sites, and subgroupings). Both analysis methods provided complementary information for evaluating which elements exceeded background concentrations (i.e., reference sites) and their likely source(s).

\subsubsection{Principal Components Analysis}

Principal components analysis (PCA) is one of the most commonly used multivariate statistical techniques for visualizing data sets with many variables (Quinn and Keough 2002). PCA is particularly well suited for data with a linear structure, such as measurements of chemical constituents in the environment (contrast this linear structure with a unimodal structure common in biological data where some optimum or maximum value exists between extremes). A PCA summarizes a large number of variables into a much smaller set of synthetic variables (also called principal components or simply axes) comprised of a linear combination of the original variables (i.e., variables responding similarly to an identified gradient or trend). The first axis of a PCA summarizes the dominant linear trend of the data set based on a combination of those variables that contributes most strongly to the trend (i.e., the combination of variables accounting for most of the variation), while the results for the second and subsequent axes account for decreasing amounts of data variation. The resulting correlation coefficients (or loadings, ranging from -1.0 to 1.0) between the original variables and each axes or principal component of the PCA provide a measure of how much they contribute to the variation in the trend displayed on each axis. In the resulting ordination diagram, those coordinates (i.e., symbols) closest to one another on the diagram are the most similar based on their combination of results for the original variables.

To visualize potential trends and help in the selection of elements to include in more detailed statistical analyses, a separate PCA was run on the results for each group of invertebrates (snails, mayfly nymphs, and mayfly adults). Mean values for each element from each site and date were used in each analysis. Because there can be no missing values in a PCA, some elements were excluded. When the number of samples with concentrations below the method detection limit was small for a specific element, concentrations were derived using one of three ways for use in the PCA.

In the data set for snails, antimony and beryllium were not detected in several samples, so those two elements were excluded from the analysis. The remaining 24 elements were detected in all samples.

All 26 elements were included in the analysis of the mayfly nymphs, although the concentrations of six elements in some samples had to be estimated. For silver, half the method detection limit (MDL) was used for the 2009 results for non-depurated nymphs from ERM 6.0. For antimony (CRM 6.0), potassium (ERM 2.5, TRM 566.7), and thallium (CRM 6.0, ERM 6.0) concentrations for non-depurated nymphs in 2010 were estimated from a regression equation based on concentrations in non-depurated (dependent variable) and depurated (independent variable) nymphs at the other sites. Similarly, for depurated nymphs from CRM 6.0 and TRM 566.7, concentrations of beryllium were estimated from the 
results of a regression analysis on depurated (dependent variable) and non-depurated (independent variable) nymphs collected from other sites in 2010. Finally, for mercury concentrations in nymphs from CRM 1.5 (depurated), ERM 2.5 (non-depurated), and LERM 1.0 (non-depurated) in 2009, results of samples analyzed by ALS in 2009 were used (mercury analyzed by EPA Method SW 7470). After visually evaluating the mercury results for nymphs from ALS and PACE for the other sites sampled in 2009 , it was felt that the results from the two laboratories were sufficiently similar to justify use of the results from ALS for CRM 1.5, ERM 2.5, and LERM 1.0.

The PCA on the adult mayflies included only 18 of the 26 elements. Aluminum, antimony, beryllium, boron, chromium, lead, nickel, and thallium were not detected in a majority of samples; therefore, they were excluded from the analysis. The only site with mercury concentrations below the MDL was TRM 567. Because mercury was detected in mayflies from the remaining sites, and because this element tends to be ubiquitous in the environment, it was felt that it unlikely to be absent from this site, therefore, a concentration of half of the MDL was used in the PCA for all adult groups from this site. Because of the close proximity of some of the locations where samples of adults were collected, a PCA was used in a preliminary assessment to evaluate whether pooling of samples from some sites would be appropriate (results not shown). Based on this analysis, collection locations for which samples were pooled included CRM 5.5, CRM 6.0, and CRM 6.2, referred to as CRM 6; ERM 1.0 and ERM 1.2, referred to as ERM 1; ERM 1.8 and ERM 2.2, referred to as ERM 2; TRM 562.5 and TRM 563.0, referred to as TRM 563; TRM 566.3 and TRM 567.6, referred to as TRM 567; and TRM 571.9 and TRM 572.5, referred to as TRM 572. Differences between ERM 1.0, ERM 1.2 and ERM 0.6 were sufficiently distinct that the latter site was not pooled with any other location.

Various subsets of the data were analyzed with a PCA to better understand which elements were contributing to apparent trends. This information was then used to help identify those elements to include in more detailed analyses (see below). The initial of each group of invertebrates included the full suite of elements, sites, dates, and subgroups (i.e., depurated and non-depurated subgroups for snails and mayfly nymphs, and male subimagos, female subimagos, male imagos, and female imagos for the adult mayflies). This was followed with an analysis that included a subset of elements that were identified as constituents of interest (COI) for the KIF Baseline Ecological Risk Assessment (BERA), including aluminum, arsenic, barium, beryllium, boron, chromium, cobalt, copper, iron, lead, manganese, mercury, molybdenum, nickel, selenium, thallium, vanadium, and zinc. The third analysis was performed on a subset of only eight elements considered by EPA to be bioaccumulative constituents of potential ecological concern including arsenic, chromium, copper, lead, mercury, nickel, selenium, and zinc. These three analyses were then repeated for each subgroup of the three invertebrate groups. For comparisons between years, only sites that had results from both years for the same subgroups were included.

Similarly, for comparisons between subimagos and imagos within sex, and males and females within each adult life stage, only sites having data for both comparison groups were included. Finally, for analyses of spatial trends within a given year, all available data for each subgroup was included.

PC-ORD for Windows software (ver. 5.32) was used for PCA. All analyses were completed on a correlation matrix, which both centers the data by column means and standardizes values by the standard deviation (McCune and Grace 2002); therefore, no other adjustments were made to the data prior to analysis. 


\subsubsection{Analysis of Individual Elements}

Based on element-specific concentration plots for each group of invertebrates, PCA results, and consideration of the constituents of interest and constituents of bioaccumulative concern referred to in the previous section, a subset of elements was selected for each group of invertebrates for more detailed analysis. In these analyses, only data for detected elements were included; if an element was not detected at a site, that site was excluded from the analysis of that element. Differences between years in the sites sampled, the subgroups analyzed, and element detectability made it impossible to perform a single comprehensive statistical analysis for each group, thus, various data subsets had to be analyzed separately (see Table 1). Some elements were excluded from these analyses because their trends were evident enough that further statistical analysis was unnecessary. Analysis included one-way and two-way analyses of variance (ANOVAs); a summary of the ANOVA models and the data subgroups analyzed is provided in Table 2. In the analyses of adult mayflies, some elements exhibited significant differences between subimagos and imagos (within sex) and males and females (within adult life stage). Therefore, only the subgroup having the highest concentrations of a specific element was included in the final analysis of adult mayflies for that element (see the Results section for further details).

The Statistical Analysis System (SAS) PROC GLM procedure (SAS for PC ver. 9.2) was used for all ANOVAs. Data for each element were initially evaluated for conformance with assumptions of normality and homogeneity of the variance (Quinn and Keough 2002). The SAS procedure PROC UNIVARIATE was used to test the data for normality with a Shapiro-Wilk test, and a Levene's test option in the SAS PROC GLM procedure was used to test for homogeneity of the variance. When assumptions were not met, an attempt was made to find a suitable transformation. In general, ANOVA is relatively robust to non-normality and heterogeneity, with heterogeneity having the greatest potential for undesirable effects on the results (Quinn and Keough 2002). Even so, excessive heterogeneity can increase the risk of not detecting a difference when a difference does actually exist (Type II errors); thus, if an analysis of a data set not meeting the assumptions is performed, the results must be interpreted with caution (Quinn and Keough 2002). Finally, the use of ANOVA to run multiple tests on the same data set increases the chances of Type I errors (i.e., mistakenly declaring that a difference exists when it does not). If an analysis is used that does not account for the potential effects of multiple testing, the results from such tests must also be interpreted carefully (Quinn and Keough 2002). In the analysis of the invertebrate bioaccumulation data sets, the assumption of homogeneity of the variance could not always be met, and the potential effect of multiple testing was not accounted for. Therefore, no alpha level was selected for accepting or rejecting factor differences. Instead, the ANOVA results were used as another line of evidence with results from the PCAs and concentration plots to help identify the elements potentially exceeding background concentrations, and their potential or likely source(s). 
Table 2. Summary of analysis of variance (ANOVA) models and site/group subsets used in the evaluation of elements assessed in the study of invertebrate bioaccumulation. See the Results section for specific elements included in each analysis.

\begin{tabular}{|c|c|c|c|c|c|c|c|}
\hline & \multirow{2}{*}{ Snails } & \multirow{2}{*}{\multicolumn{2}{|c|}{ Mayfly nymphs }} & \multicolumn{4}{|c|}{ Adult mayflies } \\
\hline & & & & \multicolumn{2}{|c|}{ Development stage and sex } & \multicolumn{2}{|c|}{ Comprehensive } \\
\hline ANOVA model & Data subset & ANOVA model & Data subset & ANOVA model & Data subset & ANOVA model & Data subset $^{1}$ \\
\hline $\begin{array}{l}\text { Single factor: } \\
\text { Site }\end{array}$ & $\begin{array}{l}\bullet 2010 \\
\bullet \text { depurated } \\
\bullet \text { ERM1.0, ERM2.5, } \\
\text { ERM4.0, ERM 6.0, } \\
\text { CRM1.5, CRM3.5, } \\
\text { CRM6.0, LERM1.0, } \\
\text { TRM566.3, TRM572.5 }\end{array}$ & $\begin{array}{c}\text { Single factor: } \\
\text { Site }\end{array}$ & $\begin{array}{l}\bullet 2010 \\
\bullet \text { non-depurated } \\
\text { •ERM1.0, ERM2.5, ERM4.0, } \\
\text { ERM 6.0, CRM1.5, CRM3.5, } \\
\text { CRM6.0, LERM1.0, } \\
\text { TRM560.8, TRM566.3, } \\
\text { TRM572.5 }\end{array}$ & $\begin{array}{l}\text { Two factor: } \\
\text { Subimago } \mathrm{x} \\
\text { imago }\end{array}$ & $\begin{array}{l}\bullet 2010 \\
\bullet \text { Females } \\
\bullet \text { CRM3.5, ERM2 }\end{array}$ & $\begin{array}{c}\text { Single factor: } \\
\text { Site }\end{array}$ & $\begin{array}{l}\bullet 2009 \\
\bullet \text { Male imagos } \\
\text { •ERM1, ERM2, ERM4.5, } \\
\text { LERM1.0, TRM563, } \\
\text { TRM567 }\end{array}$ \\
\hline $\begin{array}{l}\text { Two factor: } \\
\text { Depurated x } \\
\text { non-depurated }\end{array}$ & $\begin{array}{l}\bullet 2010 \\
\bullet \text { ERM1.0, CRM3.5, } \\
\text { ERM2.5, ERM 6.0, } \\
\text { CRM1.5, CRM6.0 }\end{array}$ & $\begin{array}{l}\text { Two factor: } \\
\text { Depurated x } \\
\text { non-depurated }\end{array}$ & $\begin{array}{l}\bullet 2010 \\
\bullet \text { ERM1.0, ERM2.5, ERM4.0, } \\
\text { ERM 6.0, CRM1.5, CRM3.5, } \\
\text { CRM6.0, LERM1.0, } \\
\text { TRM566.3, TRM572.5 }\end{array}$ & $\begin{array}{l}\text { Two factor: } \\
\text { Subimago } \mathrm{x} \\
\text { imago }\end{array}$ & $\begin{array}{l}\bullet 2010 \\
\bullet \text { Males } \\
\bullet \text { ERM0.6, ERM1, } \\
\text { ERM2, TRM563, } \\
\text { TRM567, TRM572 }\end{array}$ & $\begin{array}{l}\text { Single factor: } \\
\text { Site }\end{array}$ & $\begin{array}{l}\cdot 2010 \\
\bullet \text { Male subimagos } \\
\text { •ERM0.6, ERM1, ERM2, } \\
\text { TRM563, TRM567, TRM572 }\end{array}$ \\
\hline \multirow[t]{4}{*}{$\begin{array}{l}\text { Two-factor: } \\
\text { Site x year }\end{array}$} & $\begin{array}{l}\bullet 2009 \& 2010 \\
\bullet \text { depurated } \\
\bullet \text { ERM1.0, ERM2.5, } \\
\text { ERM 6.0, CRM1.5, } \\
\text { CRM6.0 }\end{array}$ & $\begin{array}{l}\text { Two-factor: } \\
\text { Site x year }\end{array}$ & $\begin{array}{l}\bullet \text { non-depurated } \\
\bullet \text { ERM1.0, ERM2.5, ERM 6.0, } \\
\text { CRM1.5, CRM6.0, LERM1.0 }\end{array}$ & $\begin{array}{l}\text { Two factor: } \\
\text { females x males }\end{array}$ & $\begin{array}{l}\bullet 2010 \\
\bullet \text { Subimagos } \\
\bullet \text { ERM0.6, ERM1, } \\
\text { ERM2, TRM563, } \\
\text { TRM567, TRM572 }\end{array}$ & $\begin{array}{l}\text { Single factor: } \\
\text { Site }\end{array}$ & $\begin{array}{l}\bullet 2010 \\
\bullet \text { Male imagos } \\
\bullet \text { ERM0.6, ERM1, ERM2, } \\
\text { ERM2.8, CRM1.5, CRM3.5, } \\
\text { CRM6, TRM563, TRM567, } \\
\text { TRM572 }\end{array}$ \\
\hline & & & & $\begin{array}{l}\text { Two factor: } \\
\text { females x males }\end{array}$ & $\begin{array}{l}\bullet 2010 \\
\bullet \text { Subimagos } \\
\text { •ERM2, ERM2.8, } \\
\text { CRM1.5, CRM3.5 }\end{array}$ & $\begin{array}{c}\text { Single factor: } \\
\text { Site }\end{array}$ & $\begin{array}{l}\text { •2010 } \\
\text { •Female subimagos } \\
\text { •ERM0.6, ERM1, ERM2, } \\
\text { CRM3.5, TRM563, TRM567, } \\
\text { TRM572 }\end{array}$ \\
\hline & & & & & & $\begin{array}{l}\text { Single factor: } \\
\text { Site }\end{array}$ & $\begin{array}{l}\cdot 2010 \\
\bullet \text { Female pooled (subimagos } \\
\text { and imagos) } \\
\text { •ERM0.6, ERM1, ERM2, } \\
\text { TRM563, TRM567, TRM572 }\end{array}$ \\
\hline & & & & & & $\begin{array}{l}\text { Two-factor: } \\
\text { Site x year }\end{array}$ & $\begin{array}{l}\text {-2009 \& } 2010 \\
\text { •Male imagos } \\
\text { • ERM1, ERM2, TRM563, } \\
\text { TRM567 }\end{array}$ \\
\hline
\end{tabular}

${ }^{1}$ The group subsets used in each analysis were based on maximum concentrations for specific elements; no model or subset was used for every element analyzed for adult mayflies. See the Data Analysis and Results sections for further details. 
[THIS PAGE LEFT BLANK INTENTIONALLY] 


\section{RESULTS}

\subsection{SNAILS}

\subsubsection{Principal Components Analysis}

The results from the PCA on the maximum available data set for snails showed clear and distinct spatial trends and differences between subgroups (Fig. 2a). A gradient showing the sites with the predominantly highest to lowest overall concentrations of all the elements is evident from the upper right to lower left quadrants of the PCA plot (Fig. 2a). These results suggest that concentrations of many elements were generally highest at Clinch River sites, and that ERM 1.0 generally had the highest concentrations within the Emory River. Furthermore, results from 2010 showed that this spatial gradient also was similar for both depurated and non-depurated snails. The spatial trend in 2009 was slightly different from that of 2010, with the results suggesting that concentrations of some elements were higher in snails from ERM 1.0 in 2009. The results from the PCA that included only the constituents of interest showed similar trends for subgroups and sites (results not shown), while the PCA results from the analysis of bioaccumulative elements showed more distinct spatial trends (Fig. 2b). These results specifically distinguished the three Clinch River sites and ERM 1.0, but the results also suggest that bioaccumulation of some of the contaminants were similar at ERM 6.0 and ERM 2.0. The primary bioaccumulative element distinguishing these latter two sites from the rest was $\mathrm{Pb}$ (results not shown). The results from this analysis also suggested that concentrations of contaminants were generally higher in 2010 than in 2009 at some sites. Analysis of results for depurated snails from 2009 and 2010 indicated that the greatest change in element concentrations between years occurred at CRM 6.0, CRM 1.5, and ERM 6.0 (Fig. 2c); concentrations of several elements were generally higher at these sites in 2010.

To assist in determining which elements to include in more detailed statistical analyses, the loadings (i.e., correlation coefficients) for all elements in the PCAs were evaluated. High loadings (whether positive or negative) indicate that an element was important in characterizing the trends depicted in PCA ordination plot. A summary of the elements with the highest loadings (i.e., 0.7 to 1.0 and -0.7 to 1.0) on the first PCA axis (Axis 1) is given in Table 3. These results show that all but two of the bioaccumulative elements $(\mathrm{Ni}, \mathrm{Zn})$ were important in describing trends in bioaccumulation, and that several of the constituents of interest also were important (Cd, B, Ba, Fe, $\mathrm{Mo}, \mathrm{Sr}, \mathrm{Tl}$, and V). These results also showed that $\mathrm{As}, \mathrm{Cu}, \mathrm{Pb}, \mathrm{Se}, \mathrm{Sr}$, and $\mathrm{V}$ were important in the spatial trends exhibited by both depurated and non-depurated snails.

\subsubsection{Element-Specific Results}

Mean concentrations for all elements in depurated and non-depurated snail samples are presented in Figs. 3 - 14, and in Appendix A, Tables A.1 - A.3. Based on PCA results and trends shown in the series of graphs of mean element concentrations, the elements $\mathrm{Al}, \mathrm{As}, \mathrm{Ba}, \mathrm{Cd}, \mathrm{Cr}, \mathrm{Co}, \mathrm{Cu}, \mathrm{Fe}, \mathrm{Pb}, \mathrm{Mn}$, $\mathrm{Hg}, \mathrm{Mo}, \mathrm{Ni}, \mathrm{Se}, \mathrm{Ag}, \mathrm{Sr}, \mathrm{Tl}, \mathrm{V}$, and $\mathrm{Zn}$ appeared to occur in concentrations and exhibit spatial trends that either appeared to be associated with fly ash, provide information about possible or probable alternative sources, or were of interest because they are considered bioaccumulative constituents of concern. 
Table 3. Principal component analysis loadings (i.e., correlation coefficients which range from -1.0 to 1.0) for elements in snails. Loadings from the PCAs that included the full suite of elements are shown, and only the loadings from the first axis (Axis 1) that were $\geq 0.7$ (both negative and positive) are included. A "_" in front of an element indicates a negative loading, otherwise, loadings are positive. Elements highlighted in bold text were considered good candidates for additional statistical analyses.

Those also underlined were important in both depurated and non-depurated snails.

\begin{tabular}{|c|c|c|c|c|}
\hline Analysis & $\begin{array}{l}\text { Percent of variance } \\
\text { explained by Axis } 1\end{array}$ & Loadings $>0.9$ & Loadings $0.8-0.9$ & Loadings $0.7-0.8$ \\
\hline Entire data set & $42.2 \%$ & $\mathrm{Cr}$ & None & $\begin{array}{l}\text { As, Ba, Ca, Mg, } \\
\text { Mn, K, Sr, Tl, V }\end{array}$ \\
\hline $\begin{array}{l}\text { Depurated, } 2009 \\
\text { and } 2010\end{array}$ & $48.8 \%$ & $\begin{array}{c}-\mathrm{As},-\mathbf{- C d},-\mathbf{C u}, \\
-\mathrm{Mg}\end{array}$ & $\begin{array}{c}-\mathrm{Ca},-\mathbf{C r},-\mathbf{H g} \\
-\mathbf{M o},-\mathbf{S r}\end{array}$ & $-\mathbf{F e}$ \\
\hline $\begin{array}{l}\text { Depurated, } 2010 \\
\text { only }\end{array}$ & $42.9 \%$ & $\begin{array}{c}\underline{-\mathrm{As}},-\mathbf{- C d},-\mathrm{Cr}, \\
\underline{-\mathrm{Cu}}\end{array}$ & None & 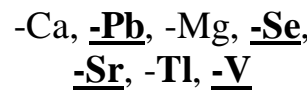 \\
\hline $\begin{array}{l}\text { Non-depurated, } \\
2010\end{array}$ & $49.9 \%$ & $-\overline{\mathrm{Ba},-\mathrm{Fe}}$ & $\begin{array}{c}-\mathbf{A l},-\mathbf{- B}, \mathrm{Ca}, \underline{\mathbf{C u}}, \\
\mathrm{Mg}, \underline{\mathbf{S r}}\end{array}$ & $\underline{\mathrm{As}}, \underline{-\overline{\mathrm{P}} \mathbf{b}}, \mathbf{H g}, \overline{\mathrm{M}} \mathbf{\mathrm { Se }}$, \\
\hline
\end{tabular}



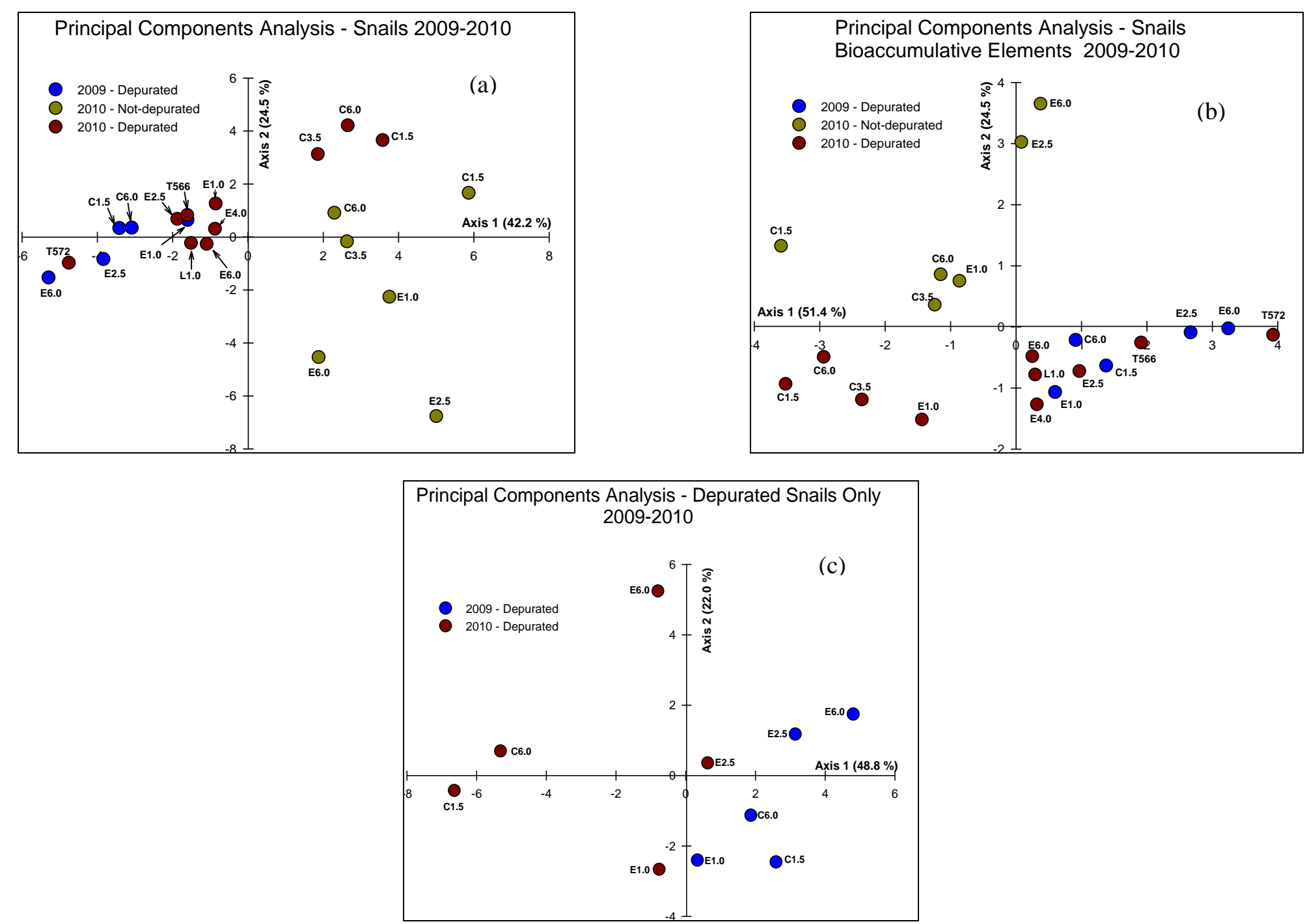

Fig. 2. Principal components analysis plots (Axis 1 and Axis 2 only) for snail bioaccumulation results in 2009 and 2010 based on an analysis (a) with 24 elements (see Table 3), (b) bioaccumulative elements of concern ( $\mathrm{As}, \mathrm{Cr}, \mathrm{Cu}, \mathrm{Pb}, \mathrm{Hg}, \mathrm{Ni}, \mathrm{Se}$, and $\mathrm{Zn}$ ), and (c) 24 elements for depurated snails only.

Mean element values from each site and sample year were used in each analysis, and each symbol represents the integrated response for all elements for a given site and date. The closer two symbols are to one another, the more similar they were in the concentrations of elements. Site names are adjacent to symbols: the numeral = river mile, and "C", "E", "L", and " $T$ " stand for Clinch, Emory, Little Emory, and Tennessee rivers respectively. 

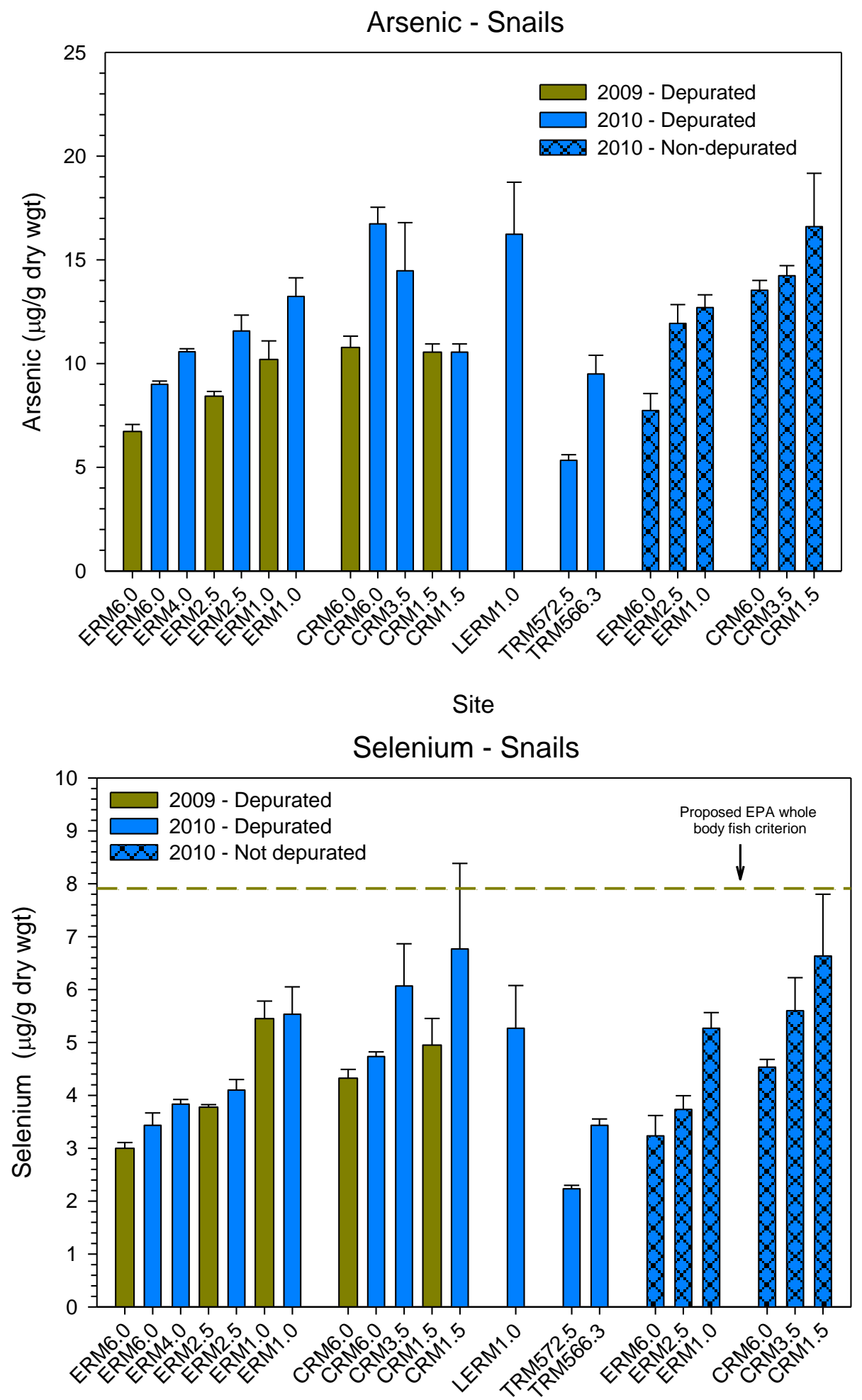

Site

Fig. 3. Mean concentrations of arsenic (top) and selenium (bottom) in snails (Pleurocera canaliculatum) from sites in the Emory River, Clinch River, Tennessee River, and Little Emory River, 2009-2010. Values are means \pm 1 SE. Horizontal line for selenium shows the proposed EPA whole body fish criterion for reference. 

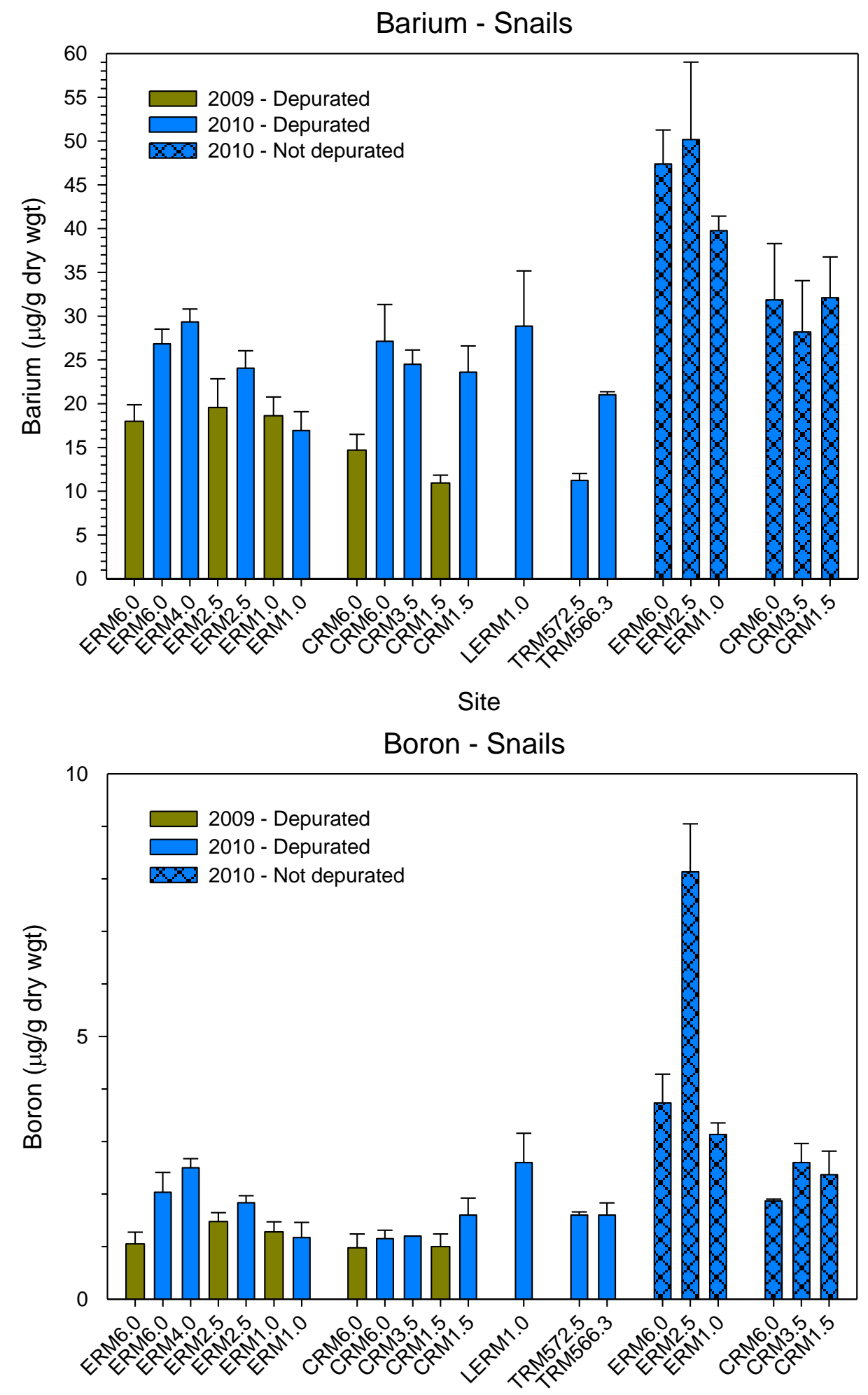

Site

Fig. 4. Mean concentrations of barium (top) and boron (bottom) in snails (Pleurocera canaliculatum) from sites in the Emory River, Clinch River, Tennessee River, and Little Emory River, 2009-2010. Values are means \pm 1 SE. 


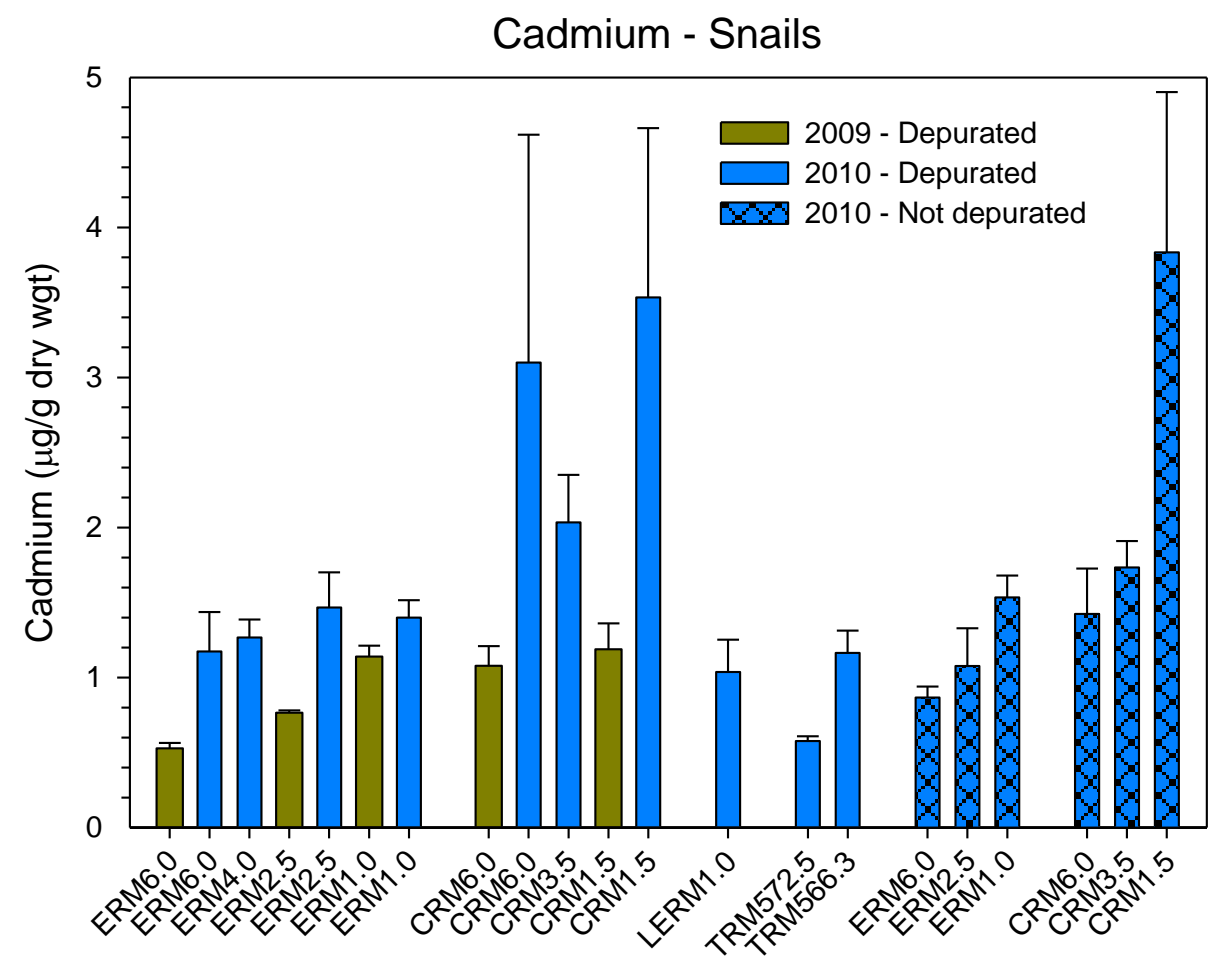

Site

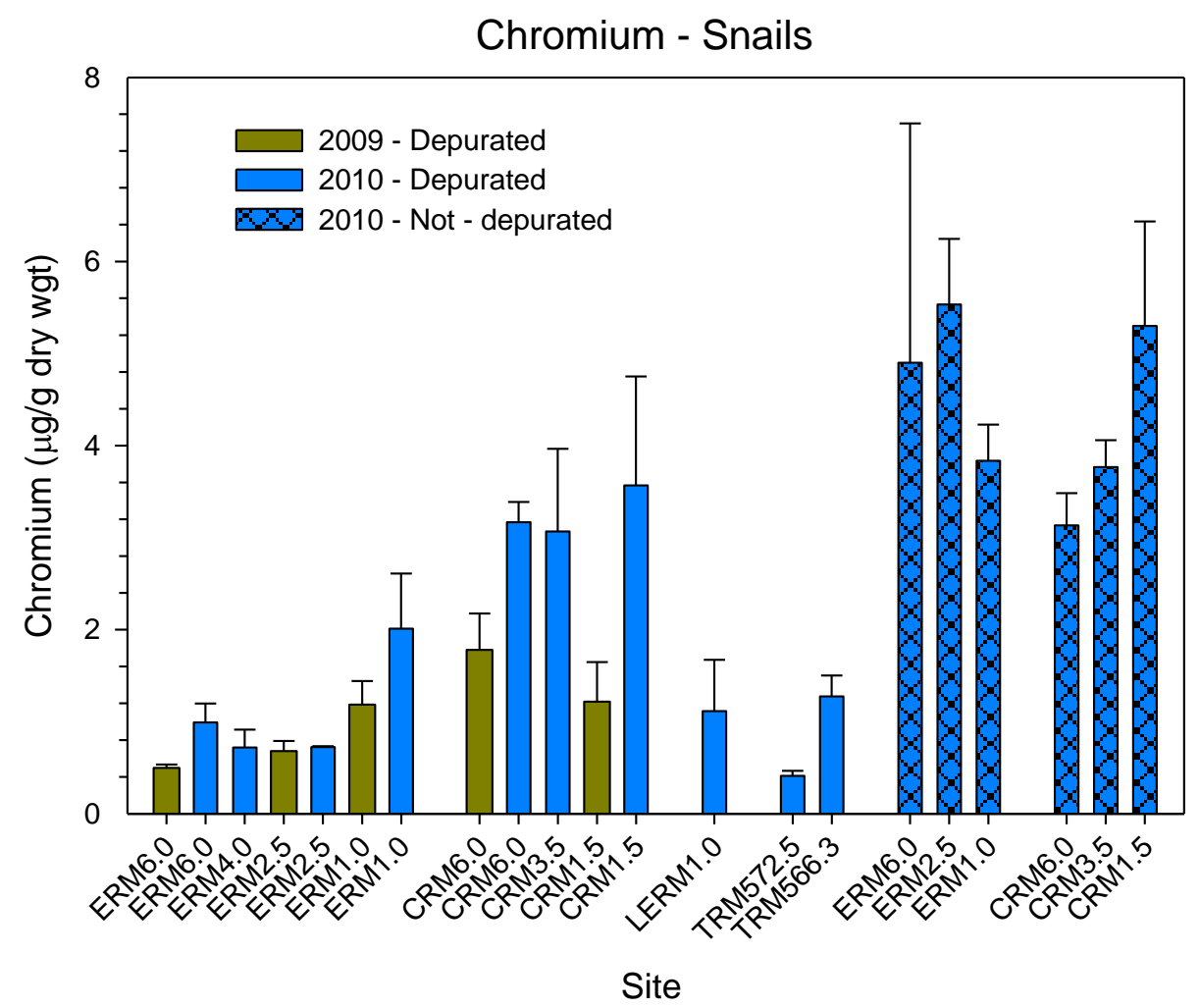

Fig.5. Mean concentrations of cadmium (top) and chromium (bottom) in snails (Pleurocera canaliculatum) from sites in the Emory River, Clinch River, Tennessee River, and Little Emory River, 2009-2010. Values are means \pm 1 SE. 


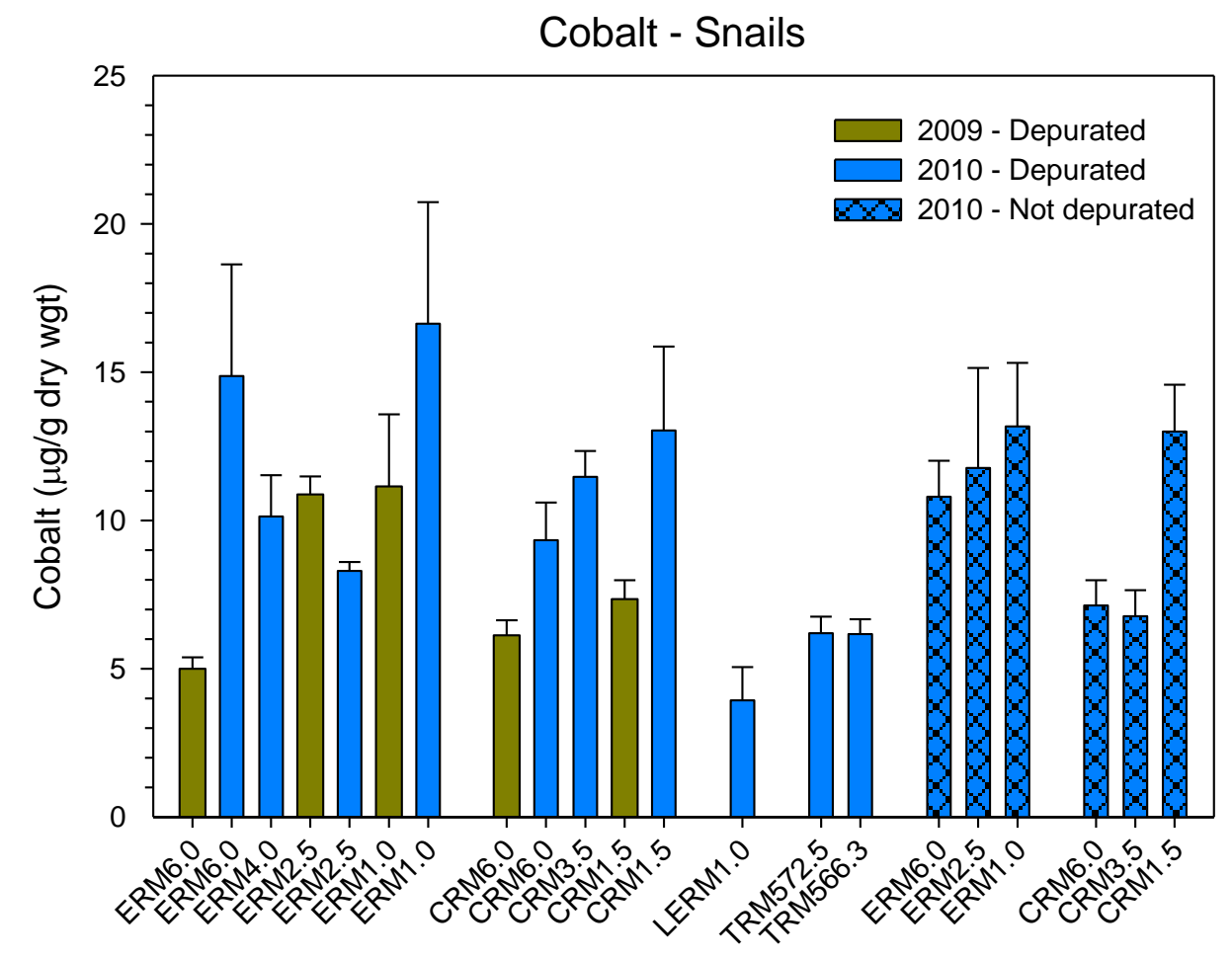

Site

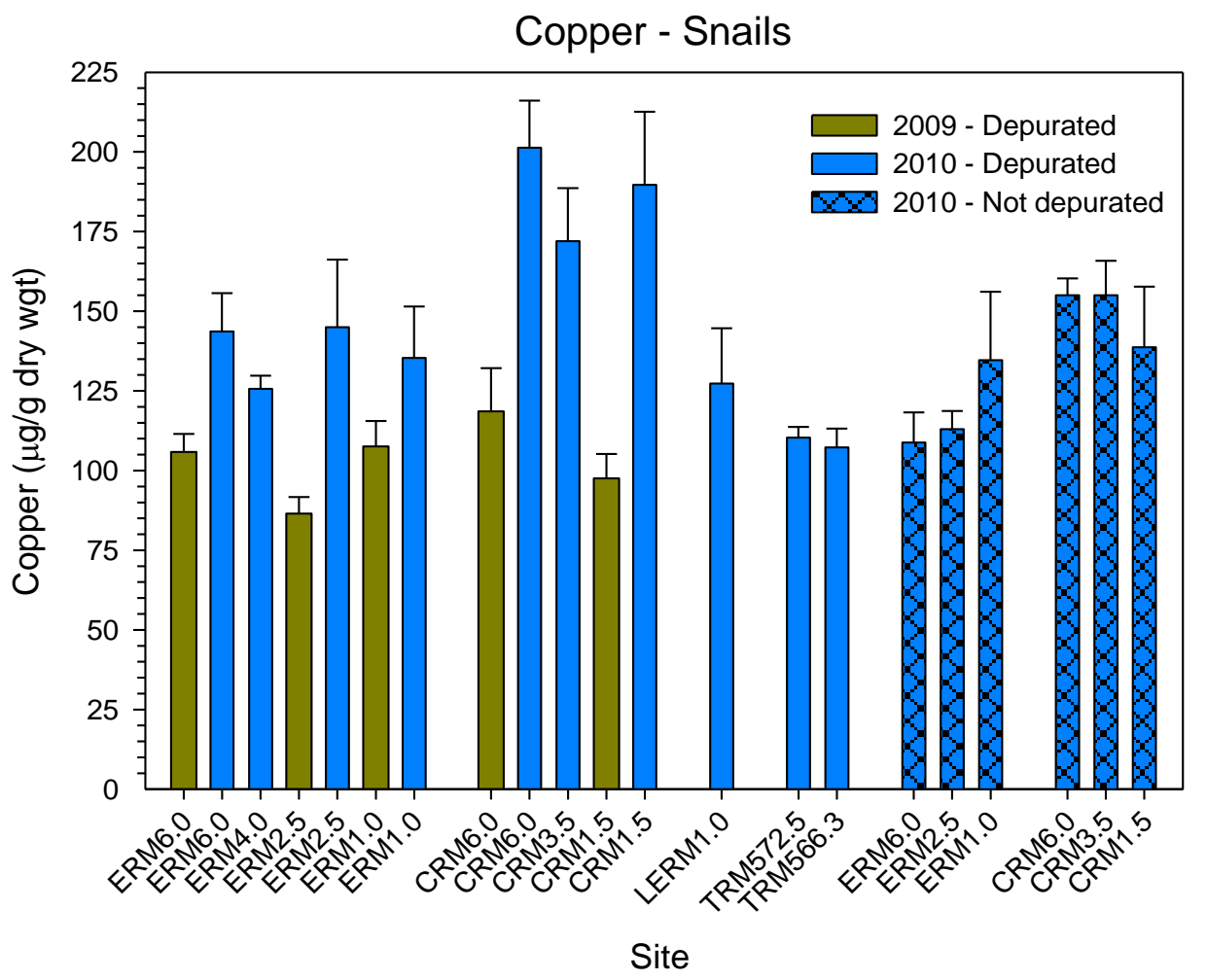

Fig.6. Mean concentrations of cobalt (top) and copper (bottom) in snails (Pleurocera canaliculatum) from sites in the Emory River, Clinch River, Tennessee River, and Little Emory River, 2009-2010. Values are means $\pm 1 \mathrm{SE}$. 
Lead - Snails

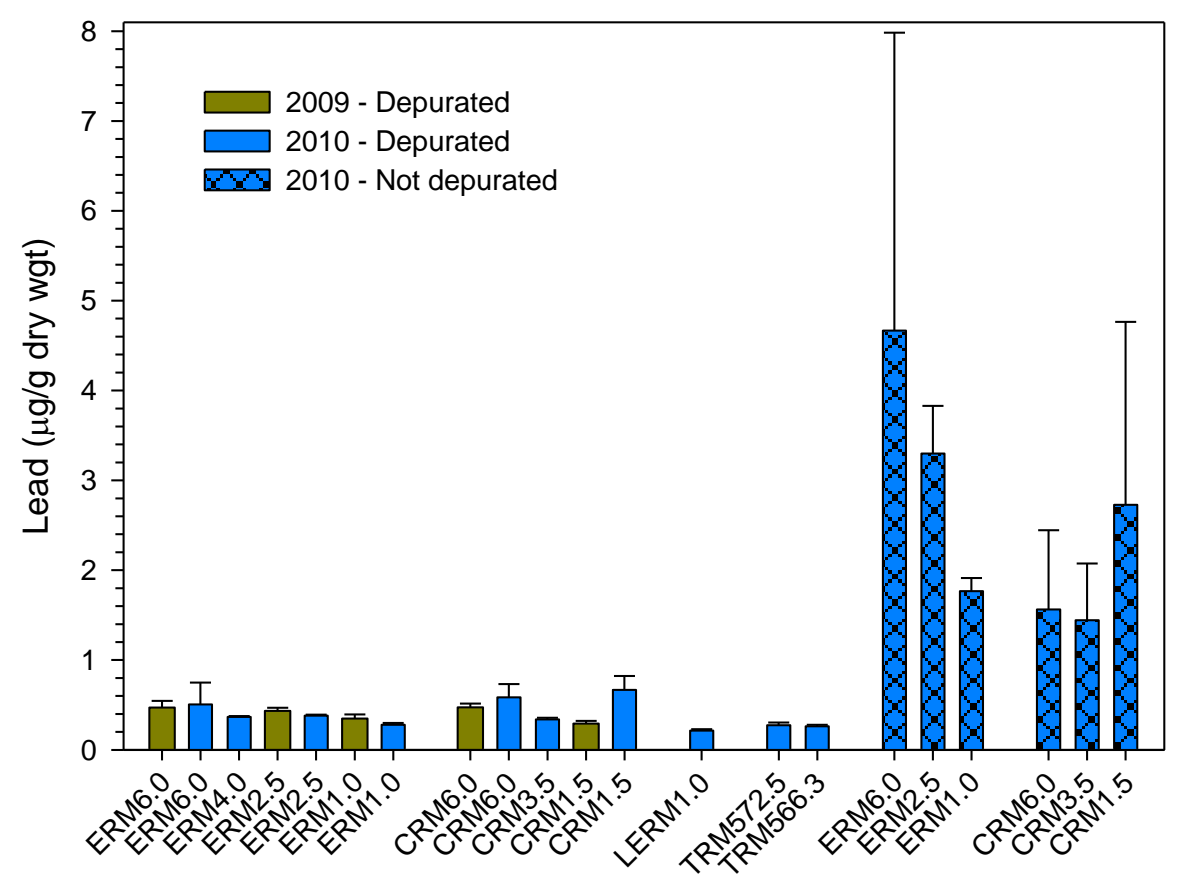

Site

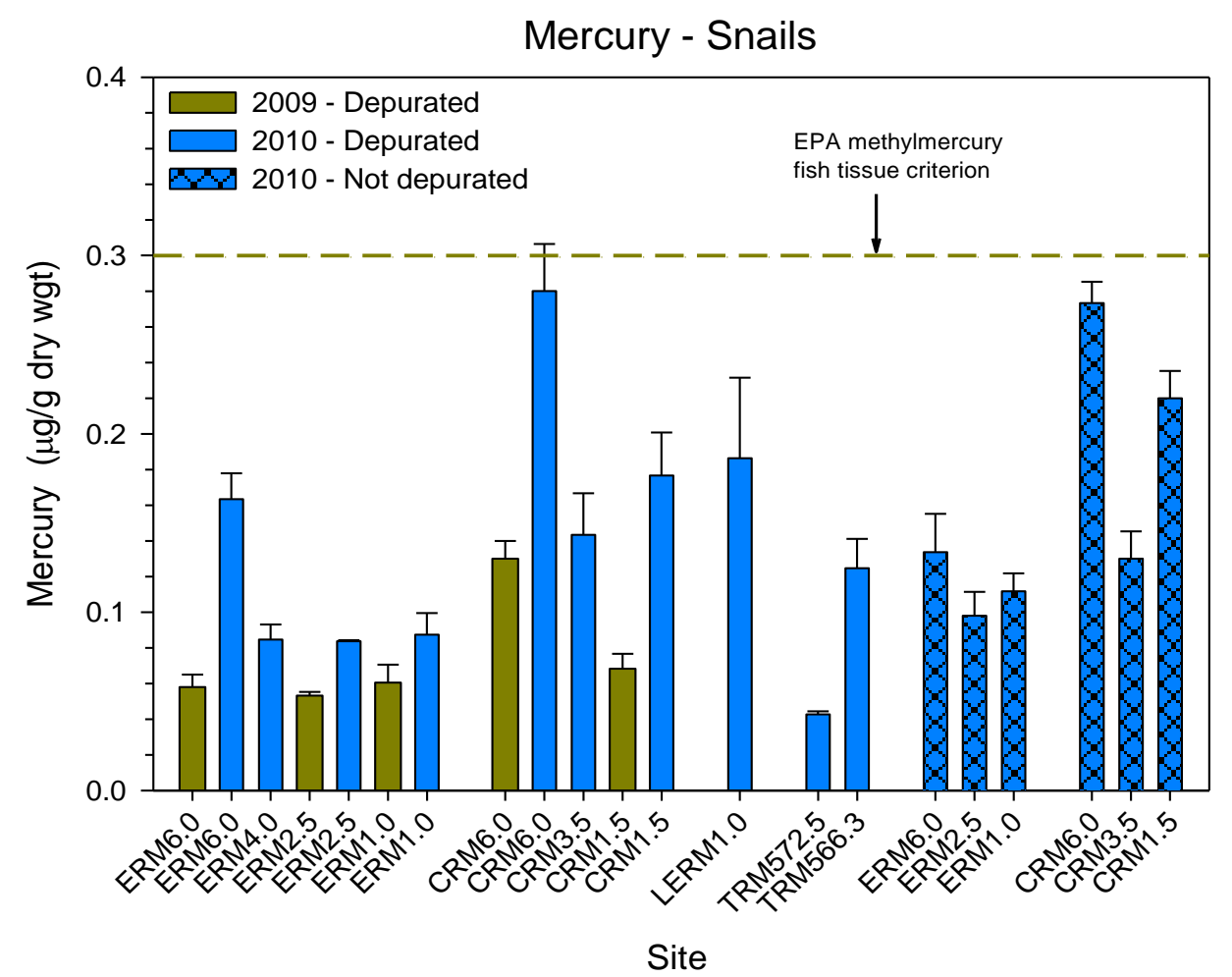

Fig.7. Mean concentrations of lead (top) and mercury (bottom) in snails (Pleurocera canaliculatum) from sites in the Emory River, Clinch River, Tennessee River, and Little Emory River, 2009-2010. Values are means \pm 1 SE. Horizontal line for mercury shows EPA's methylmercury fish tissue criterion for reference. 

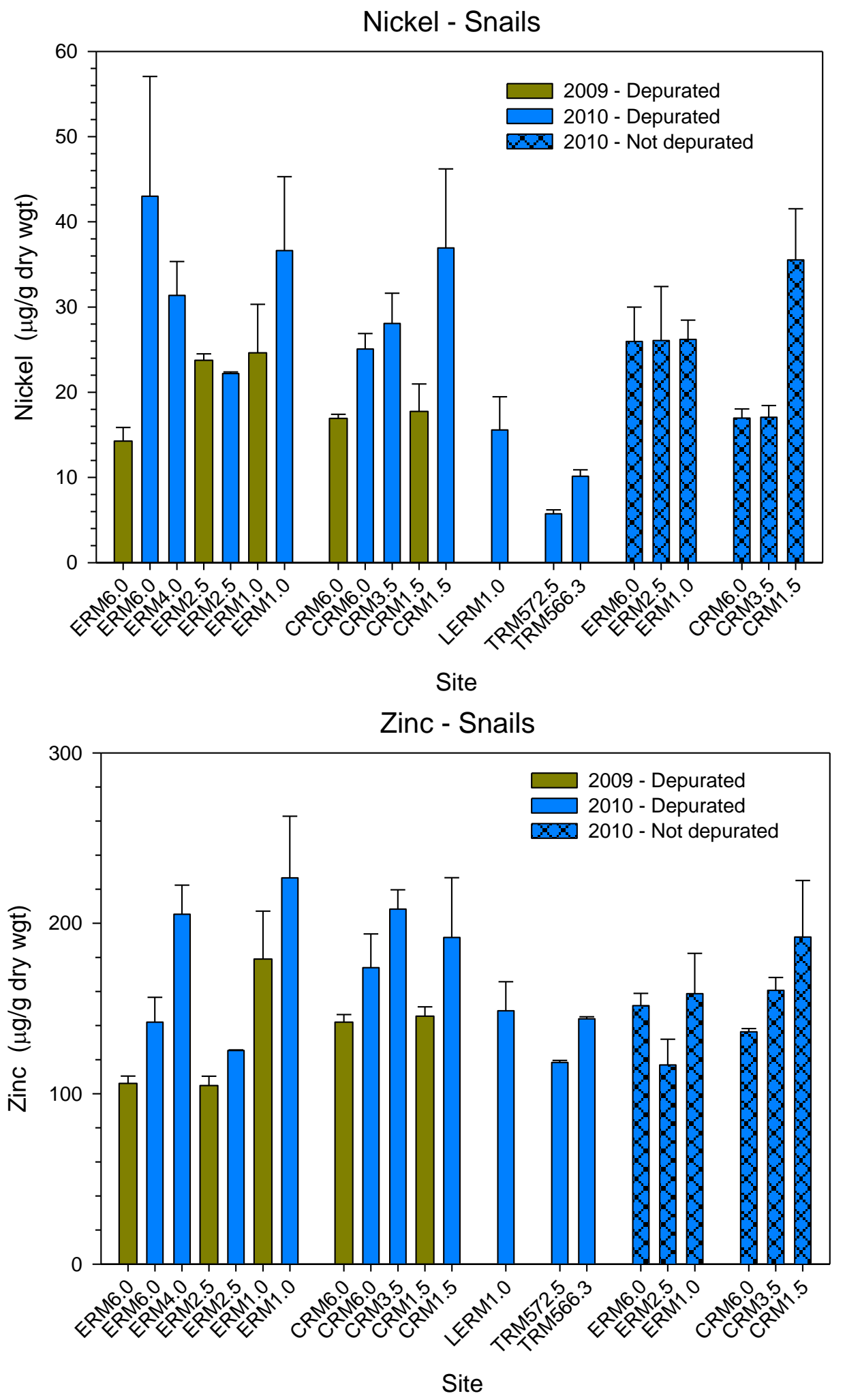

Fig.8. Mean concentrations of nickel (top) and zinc (bottom) in snails (Pleurocera canaliculatum) from sites in the Emory River, Clinch River, Tennessee River, and Little Emory River, 2009-2010. Values are means $\pm 1 \mathrm{SE}$. 
Silver - Snails

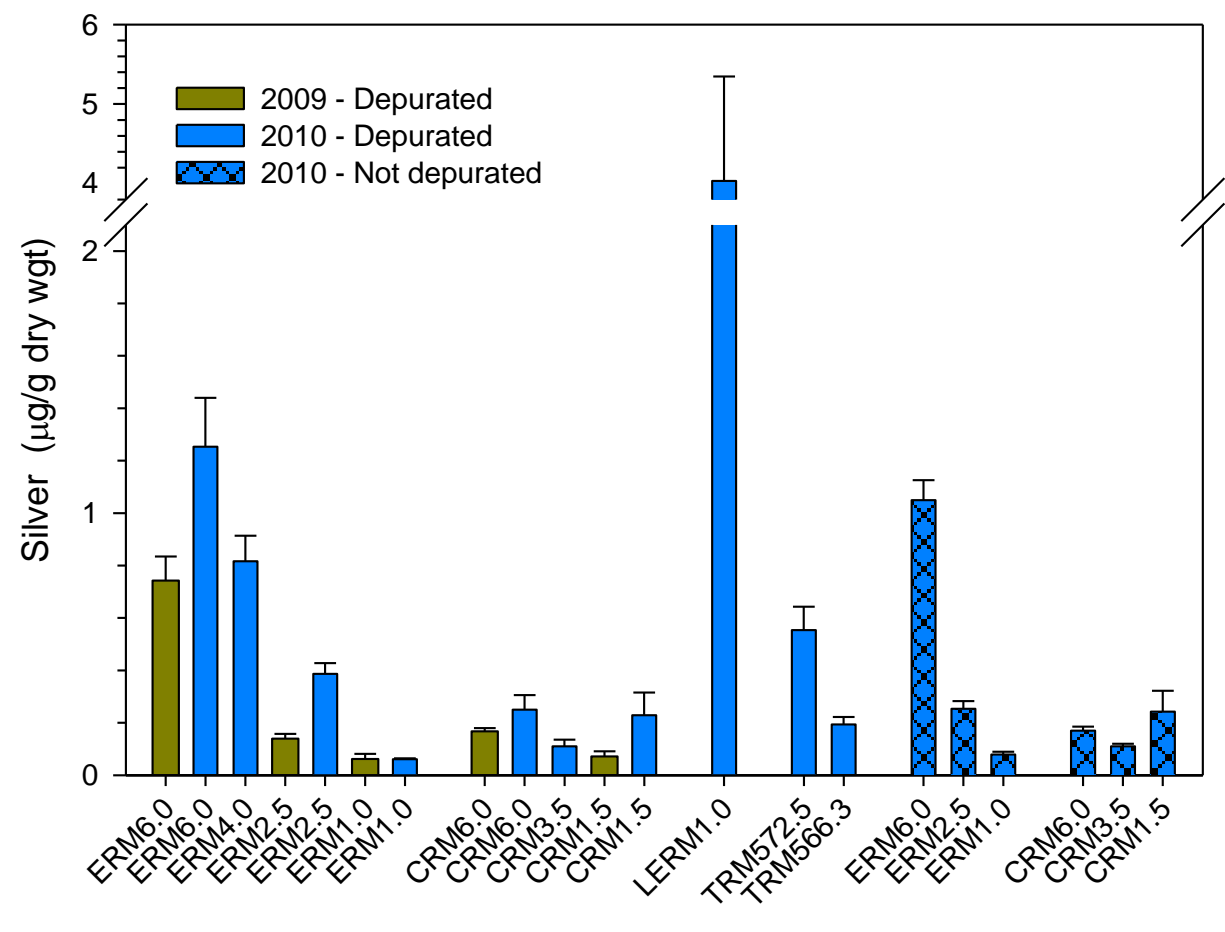

Site

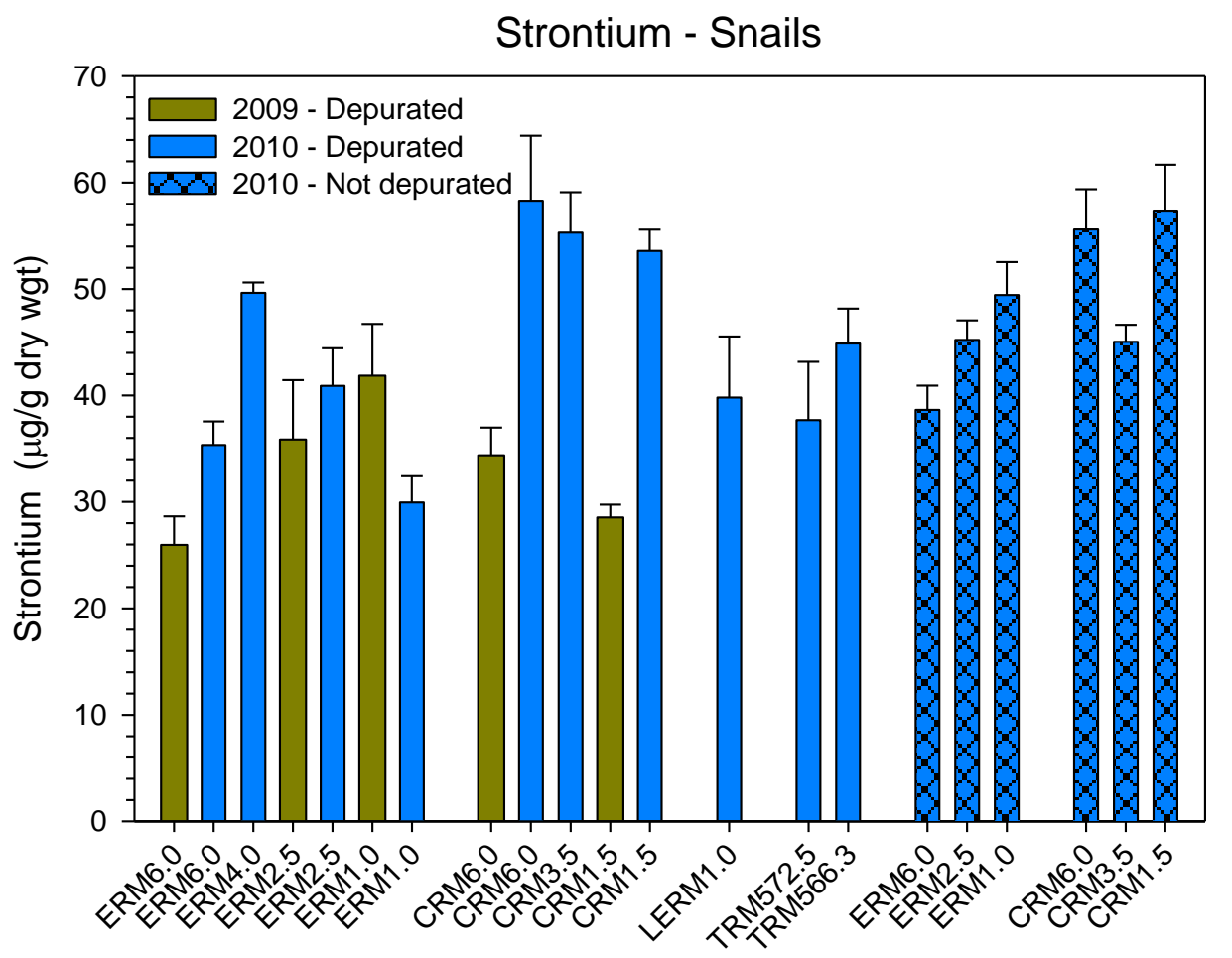

Site

Fig.9. Mean concentrations of silver (top) and strontium (bottom) in snails (Pleurocera canaliculatum) from sites in the Emory River, Clinch River, Tennessee River, and Little Emory River, 2009-2010. Values are means \pm 1 SE. 

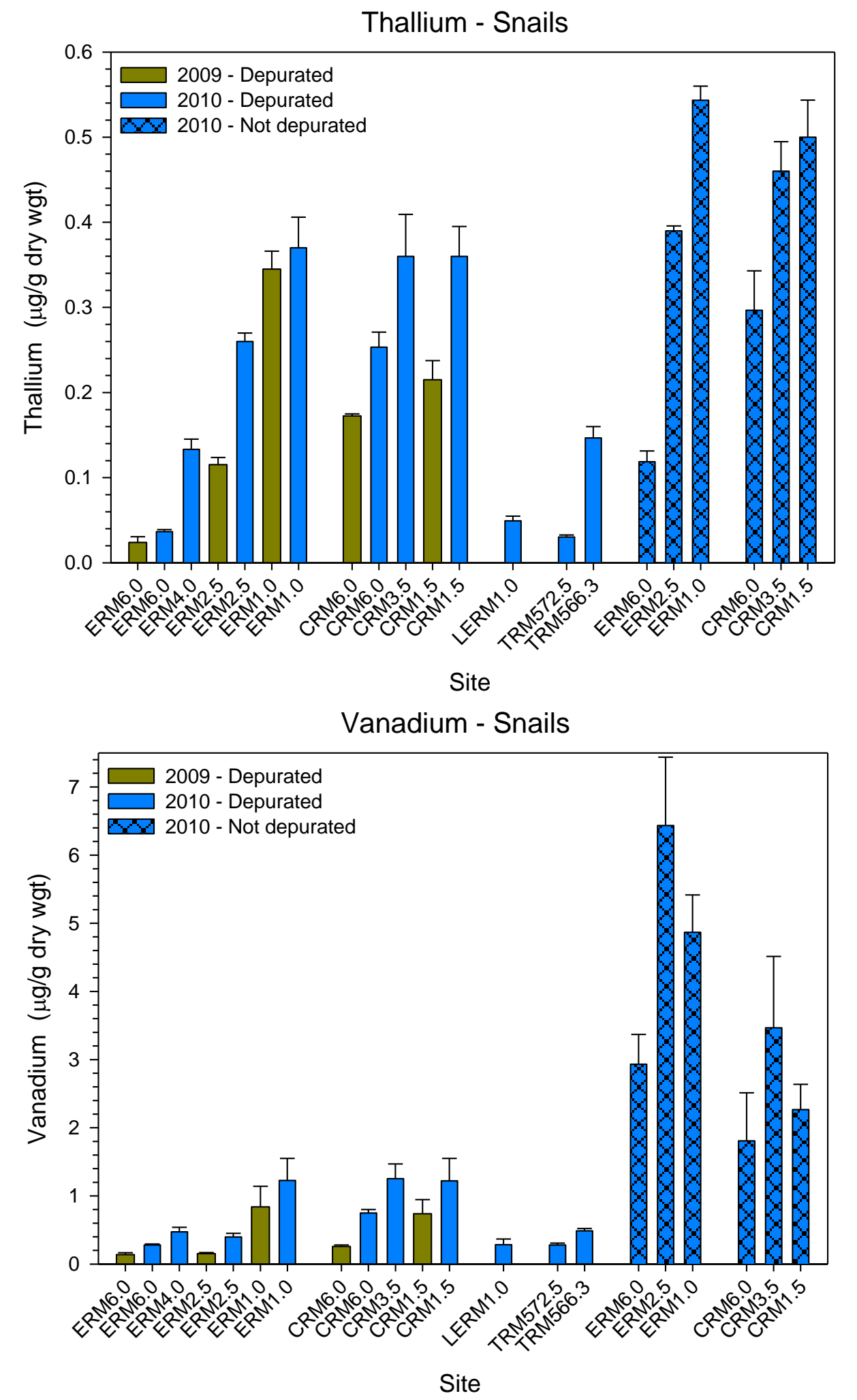

Fig.10. Mean concentrations of vanadium (top) and thallium (bottom) in snails (Pleurocera canaliculatum) from sites in the Emory River, Clinch River, Tennessee River, and Little Emory River, 2009-2010. Values are means \pm 1 SE. 

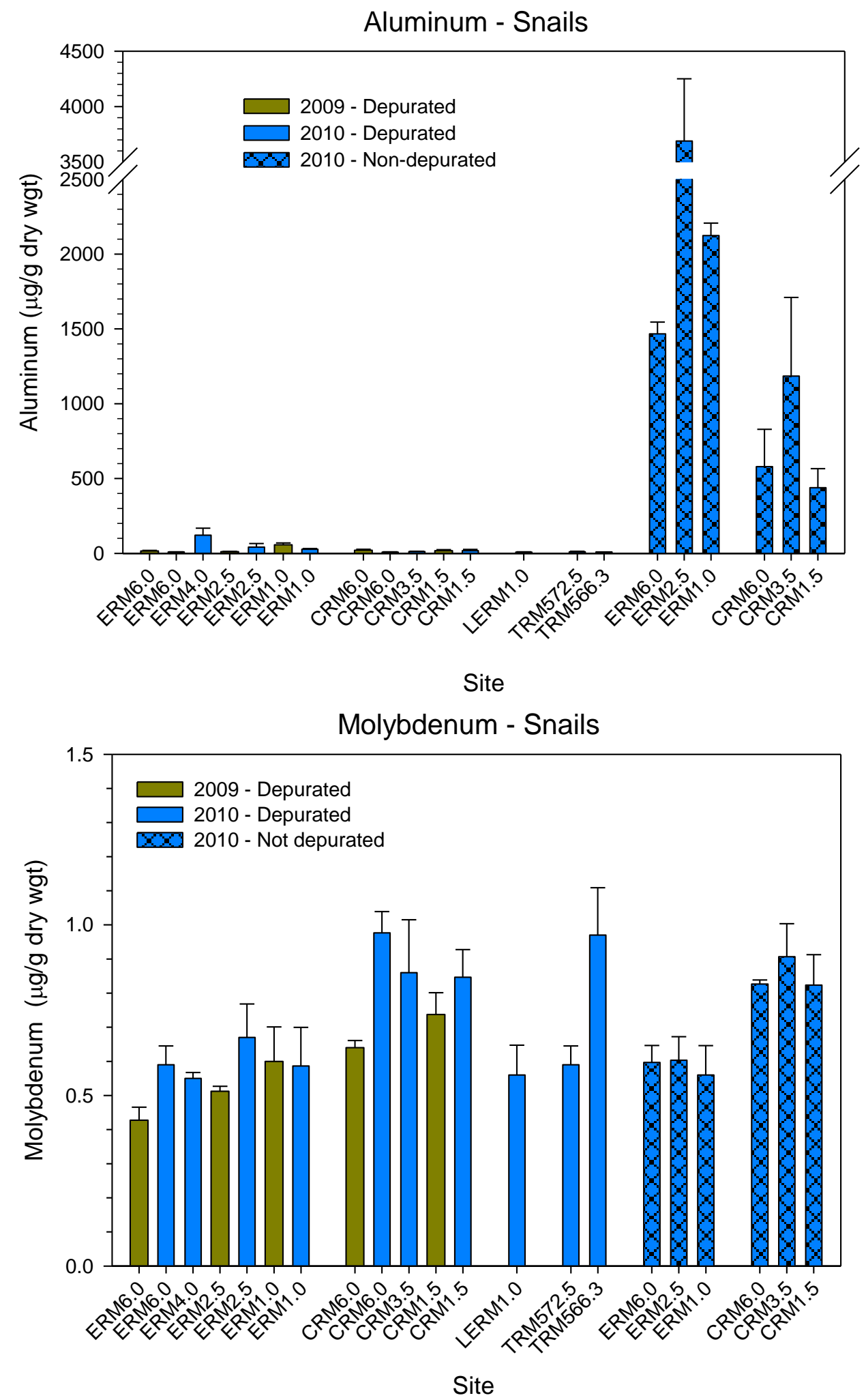

Fig.11. Mean concentrations of aluminum (top) and molybdenum (bottom) in snails (Pleurocera canaliculatum) from sites in the Emory River, Clinch River, Tennessee River, and Little Emory River, 2009-2010. Values are means \pm 1 SE. 


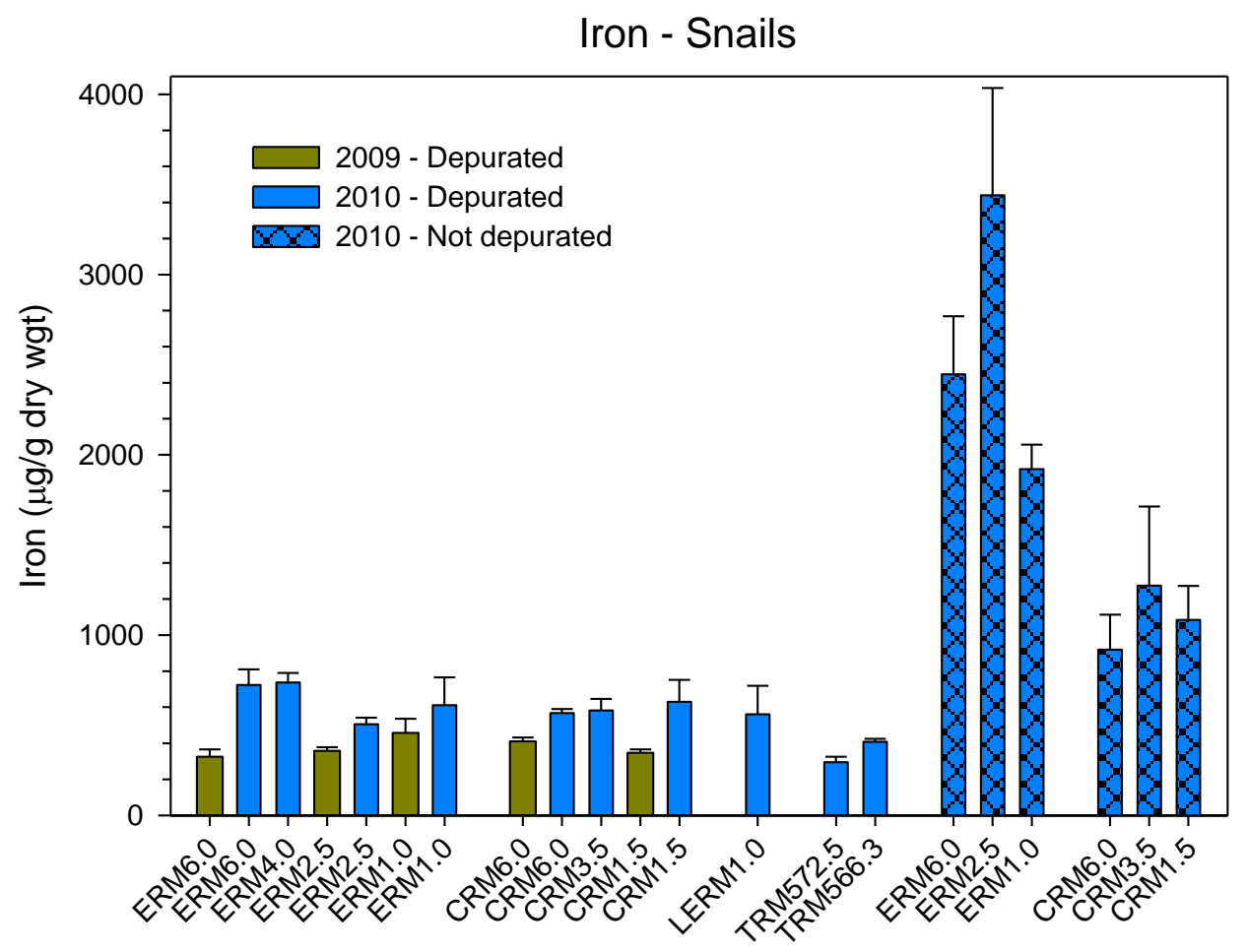

Site

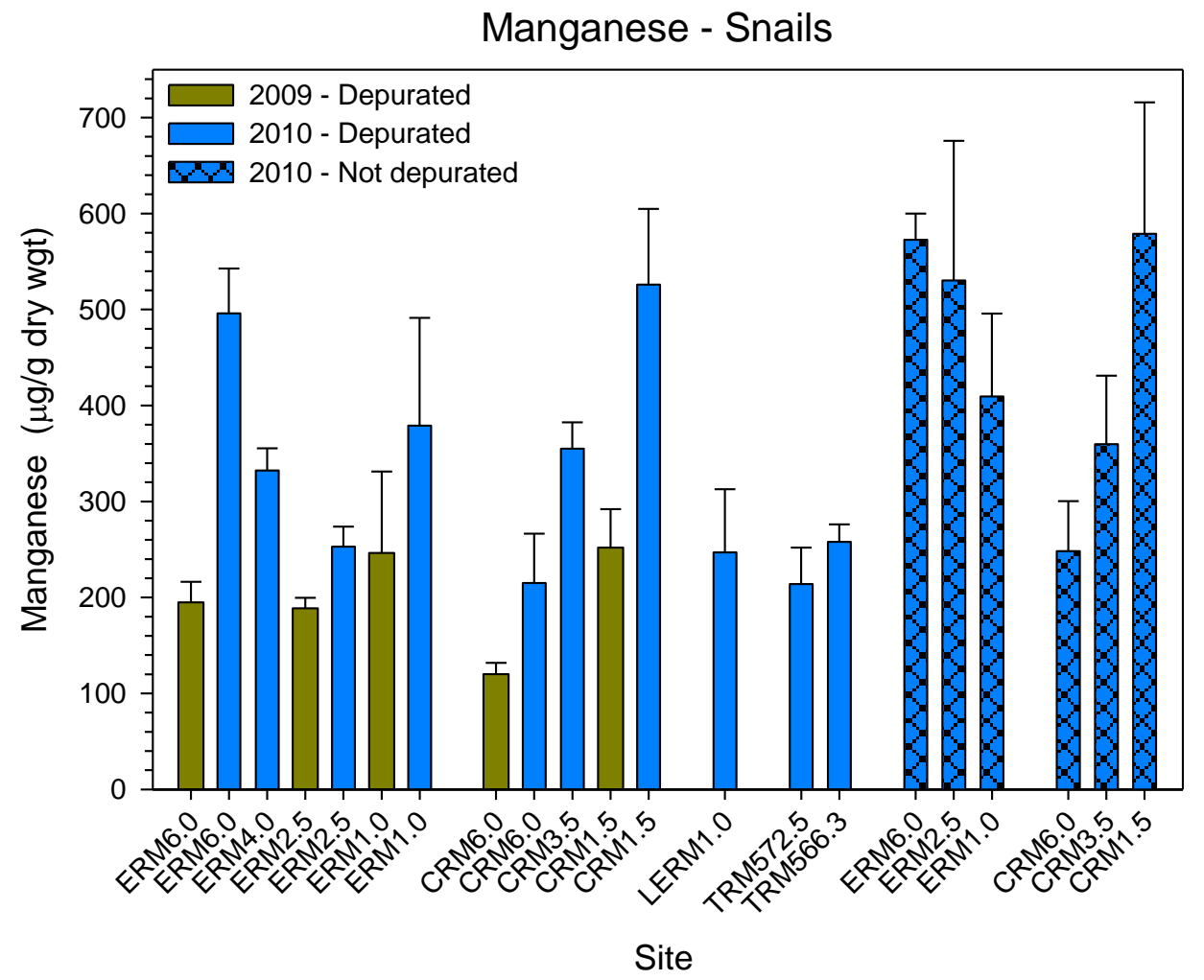

Fig.12. Mean concentrations of iron (top) and manganese (bottom) in snails (Pleurocera canaliculatum) from sites in the Emory River, Clinch River, Tennessee River, and Little Emory River, 2009-2010. Values are means \pm 1 SE. 

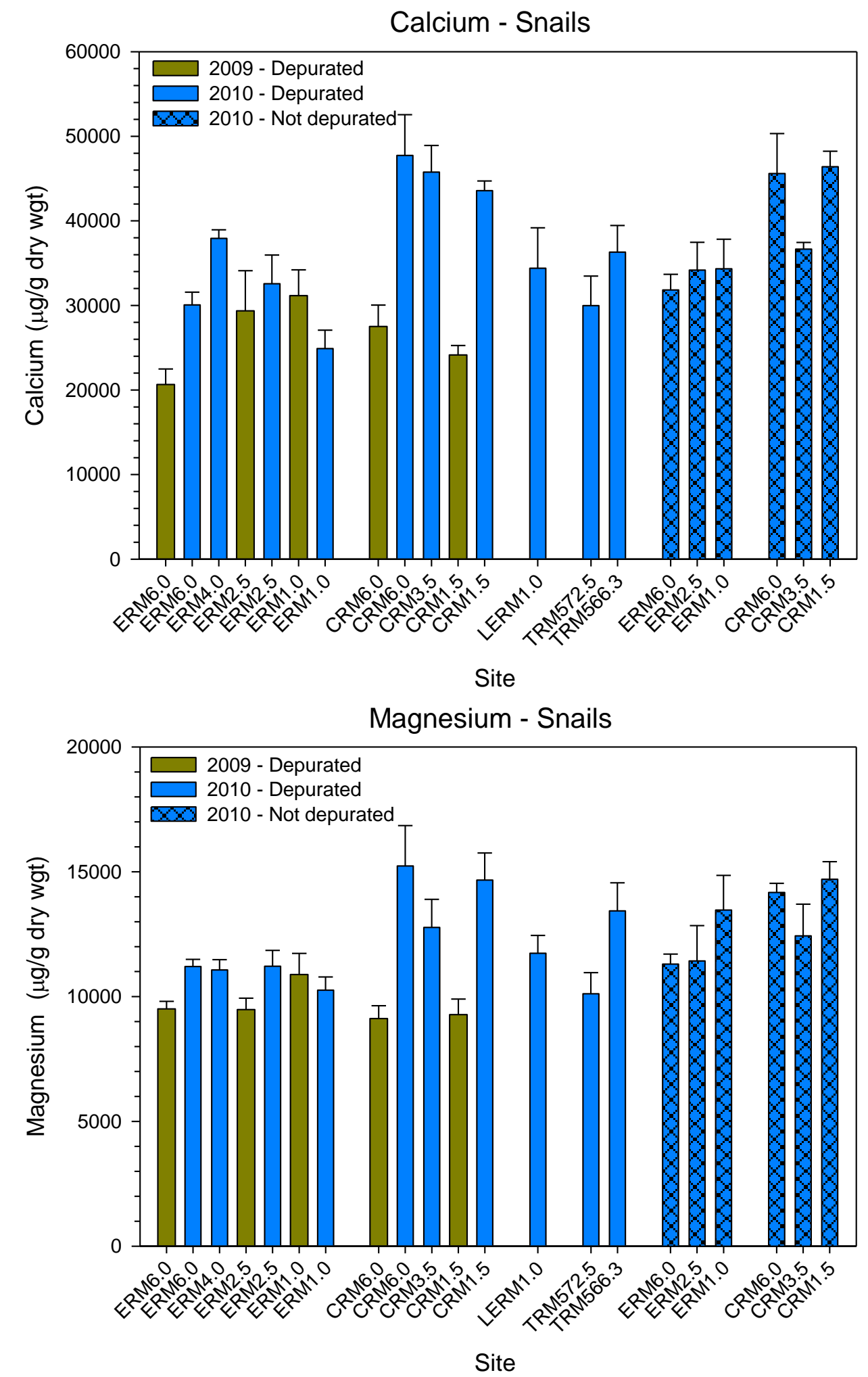

Fig. 13. Mean concentrations of calcium (top) and magnesium (bottom) in snails (Pleurocera canaliculatum) from sites in the Emory River, Clinch River, Tennessee River, and Little Emory River, 2009-2010. Values are means $\pm 1 \mathrm{SE}$. 


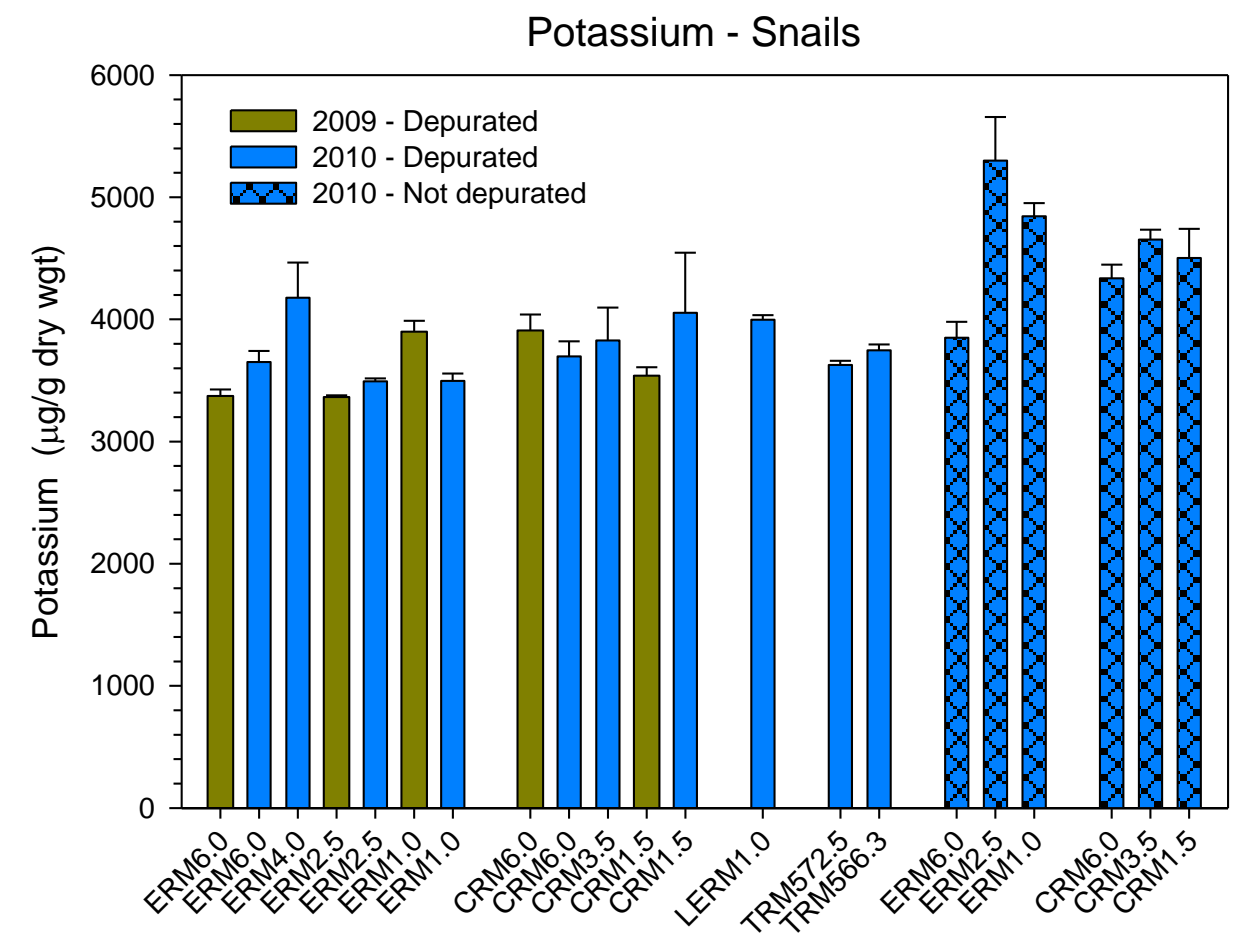

Site

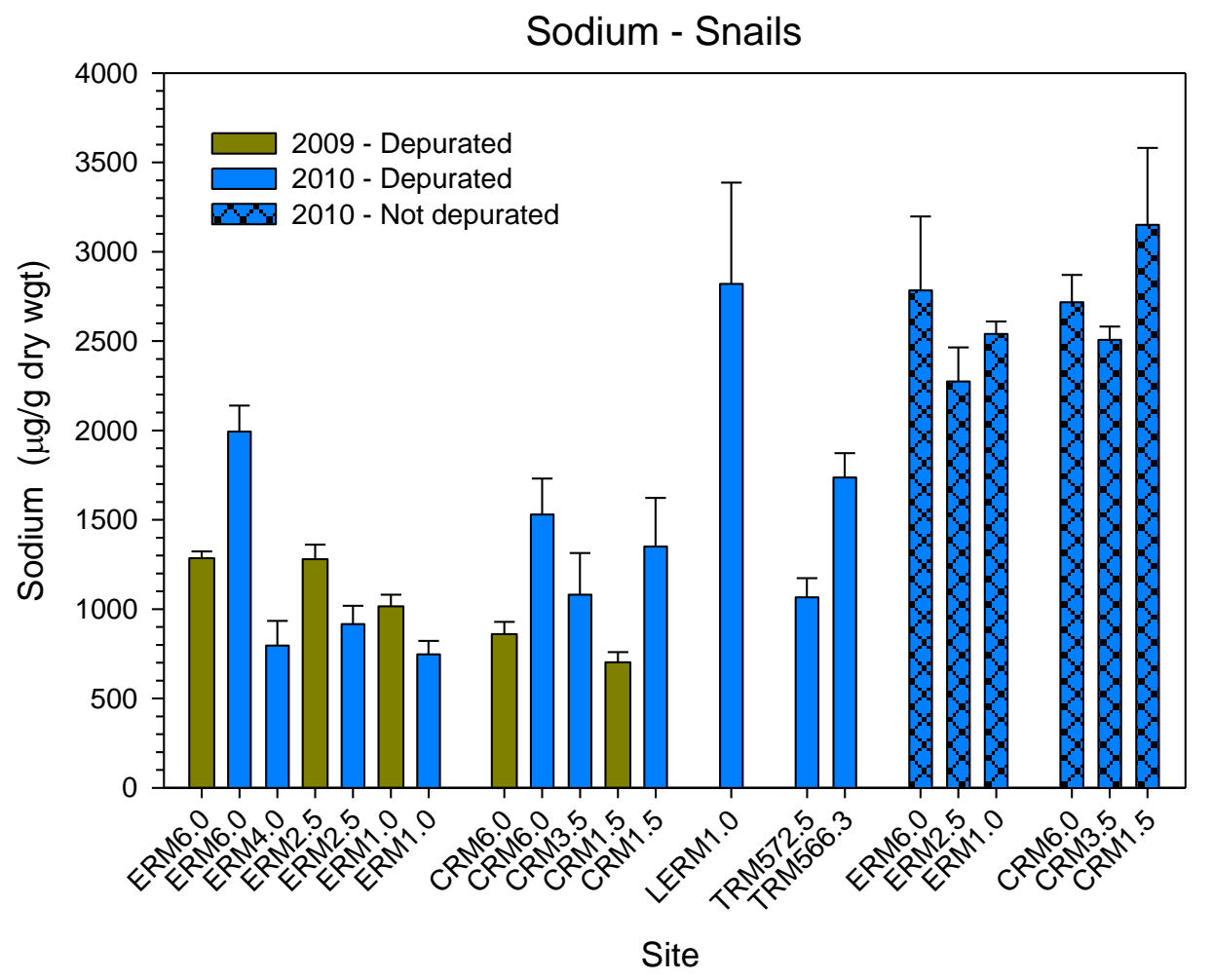

Fig.14. Mean concentrations of potassium (top) and sodium (bottom) in snails (Pleurocera canaliculatum) from sites in the Emory River, Clinch River, Tennessee River, and Little Emory River, 2009-2010. Values are means \pm 1 SE. 
Effect of depuration - Depuration had a substantial effect on the concentrations of several elements. Copper was the only element that clearly had higher concentration in depurated than nondepurated snails, although there appeared to be some indication that concentrations of Ni and Zn may have been somewhat higher in depurated snails from some sites (Figs. 6 and 8, Table 4). The elements $\mathrm{Pb}, \mathrm{Al}$, and $\mathrm{Fe}$ showed the largest decreases in concentrations in depurated snails (Figs. 7, 11, and 12). Clear decreases following depuration also were apparent for Ba (Fig. 4), while $\mathrm{Cr}$ was clearly lower in depurated snails from Emory River sites, but the effects of depuration on $\mathrm{Cr}$ concentrations in snails from Clinch River sites were ambiguous (Fig. 5). Chromium results for snails were the most heterogeneous and least responsive to various transformations than all other elements statistically evaluated. Concentrations of B, Tl, and V were lower in depurated snails, with the most notable difference occurring for V (Figs. 4 and 10). Elements appearing to have similar concentrations in depurated and non-depurated snails included As, Co, Ni, Se, and Zn (Figs. 3, 6, and 8). Cadmium, Mo, and Ag appeared to also show little difference between depurated and non-depurated snails (Figs. 5, 9, and 11). The effects of depuration on $\mathrm{Hg}$ and $\mathrm{Mn}$ varied somewhat among sites, but overall, there generally appeared to be little difference between the groups for either element (Figs. 7, 12).

Spatial and temporal trends - Not surprisingly, site differences were apparent in the concentrations of virtually every element in snails (Table 4, Figs. 3 - 14). However, only a limited number of elements showed spatial trends suggestive of a possible association with fly ash, or possibly even in response to ash removal efforts in 2010. Those elements having higher concentrations (relative to reference sites) in 2010 that were possibly associated with fly ash included As, Se, Co, Ni, Zn, Tl, and V (Table 4, Figs. 3, 6, 8, and 10), with Se, Tl, and V showing the strongest potential association. Spatial trends in $\mathrm{Tl}$ and $\mathrm{V}$ appeared to suggest that fly ash was the primary source, with the influence possibly extending as far downstream as TRM 566.3. Trends in Se appeared to be primarily associated with fly ash from KIF, but because concentrations of Se in depurated snails from LERM 1.0 and non-depurated snails from CRM 6.0 were similar to or higher than concentrations at ERM 2.5, there are most likely additional sources of Se.

Higher concentrations (relative to reference sites) of the elements $\mathrm{As}, \mathrm{Co}, \mathrm{Ni}$, and $\mathrm{Zn}$ downstream of the spill site appeared to have some association with fly ash at some locations, but there also appears to be other potential sources predominating exposures. The highest concentrations of As were found at CRM 6.0 and LERM 1.0 in depurated snails, while in non-depurated snails in 2010 there was little difference among ERM 2.5, ERM 1.0 and the three Clinch River sites. This suggests possible sources from upstream of CRM 6.0 and in the Little Emory River watershed. Highest concentrations of Co and Ni in 2009 were found at ERM 2.5 and ERM 1.0, but in 2010, the highest concentrations were found at ERM 6.0, ERM 1.0, and CRM 1.5. This suggests a possible association with ash in 2009 and 2010 (i.e., ERM 1.0 and CRM 1.5), although results from 2010 also suggest that there may be a source of Co upstream of ERM 6.0. However, because of the magnitude of difference in concentrations between 2009 and 2010 in both elements, the results also may point to possible errors associated with the collection, processing and/or analysis (analytical) of the samples, or possibly even random chance. Consistently higher concentrations of $\mathrm{Zn}$ in depurated nymphs from ERM 1.0 in 2009 and 2010 suggest a possible 
Table 4. Summary results for ANOVAs performed on individual elements in snails.

\begin{tabular}{|c|c|c|c|c|c|}
\hline Element & Model tested $^{1}$ & Model terms & $\mathrm{DF}^{2}$ & F-value & P-value \\
\hline \multirow{7}{*}{ Arsenic } & One-way (site) & Site & 9,29 & 6.75 & $<0.001$ \\
\hline & \multirow{3}{*}{ Two-way (site x year) } & Site & 4,34 & 19.64 & $<0.001$ \\
\hline & & Year & 1,34 & 59.33 & $<0.001$ \\
\hline & & Site $\mathrm{x}$ year & 4,34 & 0.65 & 0.633 \\
\hline & \multirow{3}{*}{$\begin{array}{l}\text { Two-way } \\
\text { (site } \mathrm{x} \text { depuration) }\end{array}$} & Site & 5,35 & 10.94 & $<0.001$ \\
\hline & & Depuration & 1,35 & 0.99 & 0.329 \\
\hline & & Site $\mathrm{x}$ depuration & 5,35 & 0.52 & 0.756 \\
\hline \multirow{7}{*}{ Boron } & One-way (site) & Site & 9,29 & 3.51 & 0.009 \\
\hline & \multirow{3}{*}{ Two-way (site x year) } & Site & 4,34 & 1.93 & 0.137 \\
\hline & & Year & 1,34 & 6.76 & 0.015 \\
\hline & & Site $\mathrm{x}$ year & 4,34 & 1.44 & 0.249 \\
\hline & \multirow{3}{*}{$\begin{array}{l}\text { Two-way } \\
\text { (site } \mathrm{x} \text { depuration) }\end{array}$} & Site & 5,35 & 14.02 & $<0.001$ \\
\hline & & Depuration & 1,35 & 95.96 & $<0.001$ \\
\hline & & Site $\mathrm{x}$ depuration & 5,35 & 5.88 & 0.001 \\
\hline \multirow{7}{*}{ Cobalt } & One-way (site) & Site & 9,29 & 5.69 & $<0.001$ \\
\hline & \multirow{3}{*}{ Two-way (site x year) } & Site & 4,34 & 3.18 & 0.03 \\
\hline & & Year & 1,34 & 17.81 & $<0.001$ \\
\hline & & Site $\mathrm{x}$ year & 4,34 & 4.23 & 0.009 \\
\hline & \multirow{3}{*}{$\begin{array}{l}\text { Two-way } \\
\text { (site } \mathrm{x} \text { depuration) }\end{array}$} & Site & 5,35 & 3.32 & 0.02 \\
\hline & & Depuration & 1,35 & 2.45 & 0.13 \\
\hline & & Site $\mathrm{x}$ depuration & 5,35 & 1.23 & 0.327 \\
\hline \multirow{7}{*}{ Copper } & One-way (site) & Site & 9,29 & 4.44 & 0.003 \\
\hline & \multirow{3}{*}{ Two-way (site x year) } & Site & 4,34 & 3.28 & 0.027 \\
\hline & & Year & 1,34 & 52.97 & $<0.001$ \\
\hline & & Site $\mathrm{x}$ year & 4,34 & 1.71 & 0.179 \\
\hline & \multirow{3}{*}{$\begin{array}{l}\text { Two-way } \\
\text { (site } \mathrm{x} \text { depuration) }\end{array}$} & Site & 5,35 & 3.89 & 0.01 \\
\hline & & Depuration & 1,35 & 11.15 & 0.003 \\
\hline & & Site $\mathrm{x}$ depuration & 5,35 & 0.71 & 0.619 \\
\hline \multirow{7}{*}{ Nickel } & One-way (site) & Site & 9,29 & 9.67 & $<0.001$ \\
\hline & \multirow{3}{*}{ Two-way (site x year) } & Site & 4,34 & 0.8 & 0.536 \\
\hline & & Year & 1,34 & 19.43 & $<0.001$ \\
\hline & & Site $\mathrm{x}$ year & 4,34 & 2.61 & 0.06 \\
\hline & \multirow{3}{*}{$\begin{array}{l}\text { Two-way } \\
\text { (site } \mathrm{x} \text { depuration) }\end{array}$} & Site & 5,35 & 2.67 & 0.047 \\
\hline & & Depuration & 1,35 & 5.29 & 0.03 \\
\hline & & Site $\mathrm{x}$ depuration & 5,35 & 0.84 & 0.535 \\
\hline \multirow{7}{*}{ Selenium } & One-way (site) & Site & 9,29 & 6.36 & $<0.001$ \\
\hline & \multirow{3}{*}{ Two-way (site x year) } & Site & 4,34 & 11.57 & $<0.001$ \\
\hline & & Year & 1,34 & 3.70 & 0.066 \\
\hline & & Site $\mathrm{x}$ year & 4,34 & 0.52 & 0.719 \\
\hline & \multirow{3}{*}{$\begin{array}{l}\text { Two-way } \\
\text { (site } \mathrm{x} \text { depuration) }\end{array}$} & Site & 5,35 & 7.63 & $<0.001$ \\
\hline & & Depuration & 1,35 & 0.51 & 0.483 \\
\hline & & Site $\mathrm{x}$ depuration & 5,35 & 0.4 & 0.999 \\
\hline \multirow{7}{*}{ Zinc } & One-way (site) & Site & 9,29 & 4.35 & 0.003 \\
\hline & \multirow{3}{*}{ Two-way (site x year) } & Site & 4,34 & 9.17 & $<0.001$ \\
\hline & & Year & 1,34 & 12.48 & 0.002 \\
\hline & & Site $\mathrm{x}$ year & 4,34 & 0.08 & 0.987 \\
\hline & \multirow{3}{*}{$\begin{array}{l}\text { Two-way } \\
\text { (site } \mathrm{x} \text { depuration) }\end{array}$} & Site & 5,35 & 4.30 & 0.006 \\
\hline & & Depuration & 1,35 & 4.25 & 0.05 \\
\hline & & Site $\mathrm{x}$ depuration & 5,35 & 0.96 & 0.461 \\
\hline
\end{tabular}




\begin{tabular}{|c|c|c|c|c|c|}
\hline Element & Model tested $^{1}$ & Model terms & $\mathrm{DF}^{2}$ & F-value & P-value \\
\hline \multirow{5}{*}{ Thallium $^{3}$} & One-way (site) & Site $^{4}$ & 4,14 & 81.01 & $<0.001$ \\
\hline & One-way (site) & Site $^{5}$ & 3,11 & 26.45 & $<0.001$ \\
\hline & \multirow{3}{*}{$\begin{array}{l}\text { Two-way } \\
\text { (site x depuration) }\end{array}$} & Site & 5,35 & 42.88 & $<0.001$ \\
\hline & & Depuration & 1,35 & 40.28 & $<0.001$ \\
\hline & & Site $\mathrm{x}$ depuration & 5,35 & 1.15 & 0.362 \\
\hline \multirow{5}{*}{ Vanadium $^{3}$} & One-way (site) & Site $^{4}$ & 4,14 & 7.23 & 0.005 \\
\hline & One-way (site) & Site $^{5}$ & 3,11 & 6.35 & 0.016 \\
\hline & \multirow{3}{*}{$\begin{array}{l}\text { Two-way } \\
\text { (site x depuration) }\end{array}$} & Site & 5,35 & 4.36 & 0.006 \\
\hline & & Depuration & 1,35 & 119.35 & $<0.001$ \\
\hline & & Site $\mathrm{x}$ depuration & 5,35 & 6.20 & $<0.001$ \\
\hline
\end{tabular}

${ }^{\mathrm{I}}$ One-way and two-way models (site $\mathrm{x}$ year) only included snails that had been depurated.

${ }^{2} \mathrm{DF}=$ degrees of freedom.

${ }^{3}$ Two-way ANOVA on factors of site $\mathrm{x}$ time was not completed due to the inability to correct the data for excessive non-normality and heterogeneity.

${ }^{4}$ Analysis included only the four Emory River sites and LERM 1.0.

${ }^{5}$ Analysis included only the three Clinch River sites and LERM 1.0.

ash association, but comparable concentrations in snails from ERM 4.0 in 2010 suggests a potential additional source upstream of the ash spill. Furthermore, there was little difference between nondepurated snails from ERM 6.0 and ERM 1.0 in concentrations of $\mathrm{Zn}$ in 2010.

The primary source of $\mathrm{Hg}$ was clearly the Clinch River watershed, with highest concentrations in snails found at CRM 6.0 in both years (Fig. 7). Furthermore, concentrations of $\mathrm{Hg}$ in depurated snails were higher at ERM 6.0 and LERM 1.0 that at sites in the lower Emory River in 2010. Concentrations of $\mathrm{Cu}$ and Mo where generally highest in snails from Clinch River sites (depurated and non-depurated), and concentrations of Mo in depurated snails from TRM 566.3 in 2010 were similar to those from the Clinch River sites (Figs. 6 and 11). There was little difference among Emory River sites in 2010, but in 2009, there appeared to be some enrichment in Mo concentrations at ERM 1.0 relative to ERM 6.0.

In 2009, Cd concentrations in depurated snails from ERM 1.0 were approximately two times higher than at ERM 6.0, but were similar to the concentrations in snails from Clinch River sites (Fig. 5). Cadmium concentrations in depurated snails were higher at all Emory River sites in 2010, with the largest difference between years at ERM 6.0 where the concentration was nearly two times higher. Concentrations in depurated snails from Clinch River sites, on the other hand were at least three times higher in 2010 than in 2009. Additionally, differences between depurated and non-depurated snails in 2010 suggest that snails were bioaccumulating Cd more efficiently at CRM 6.0 (concentrations much higher in depurated snails) than at CRM 1.5 (little difference between depurated and non-depurated snails). While fly ash cannot be eliminated as a possible source of $\mathrm{Cd}$ in 2009, results from 2010 suggest that there is probably a source of Cd upstream of CRM 6.0.

Like Cd, the spatial trend exhibited by depurated snails in $\mathrm{Sr}$ in 2009 appeared to suggest a possible increase at ERM 1.0 and ERM 2.5 (Fig. 9). In 2010, the highest concentration found in depurated snails from the Emory River was at ERM 4.0, while and the lowest concentration was found at ERM 1.0. Concentrations of Sr at Clinch River sites in 2009 were comparable to or slightly lower than those at the lower Emory River sites, but in 2010 concentrations were nearly two times higher at the Clinch River sites. Concentrations of Cd in non-depurated snails in 2010 were highest at CRM 6.0 and CRM 1.5. Thus, like $\mathrm{Cd}$ fly ash cannot be eliminated as a possible source of $\mathrm{Sr}$ to snails, but results from 2010 suggest that the Clinch River also may serve as a source of $\mathrm{Sr}$. 
Concentrations of $\mathrm{Al}$ were as much as 150 orders of magnitude higher in non-depurated than depurated snails in 2010, thus, clearly showing that $\mathrm{Al}$ is not bioaccumulating in snails (Fig. 11). The highest concentrations of $\mathrm{Al}$ in non-depurated snails were found at Emory River sites where they were at least three times higher than at the Clinch River sites. Among the Emory River sites, concentrations of $\mathrm{Al}$ at ERM 2.5 were $\sim 1.7$ to 2.5 times higher than at the other sites.

Spatial trends in the concentrations of $\mathrm{Ba}, \mathrm{B}$, and $\mathrm{Fe}$ in depurated snails showed little difference among sites, and concentrations of all three elements were higher in 2010 at all sites except for Ba and B at ERM 1.0 (Figs. 4 and 12). Barium in non-depurated snails in 2010 showed no spatial trend that would suggest an association with fly ash, but concentrations of B and Fe were clearly much higher at ERM 2.5 than at the other sites. Furthermore, Fe and $\mathrm{Ba}$ in non-depurated snails appeared to have a strong association with river, with higher concentrations occurring at Emory River sites.

Temporally, results suggest that concentrations of most elements in depurated snails were higher in 2010 than in 2009 at most sites (Table 4). Elements generally showing little or no change between years were $\mathrm{Pb}$ and $\mathrm{Al}$ (Figs. 7 and 11), while $\mathrm{K}$ and $\mathrm{Na}$ displayed a range of increases and decreases across sites (Fig. 14). While concentrations of most other elements were generally higher at most sites in 2010, trends for several elements were somewhat different at ERM 1.0 and ERM 2.5 than at other sites. At ERM 1.0, concentrations of Ba, B, Sr, Ca, and Mg were lower in 2010, and Mo and Ag concentrations did not change (Figs. 4, 9, 11, and 13). At ERM 2.5, concentrations of Co and Ni were lower in 2010, while $\mathrm{Cr}$ showed no between-year change.

\subsection{MAYFLY NYMPHS}

\subsubsection{Principal Components Analysis}

The spatial trends and differences between depurated and non-depurated mayfly nymphs shown by the results of the PCA were even more distinct than those for snails (Fig. 15). As for the snails, spatial trends for depurated and non-depurated nymphs were similar and the plot for the results from the PCA suggested that concentration differences among sites for some elements were less in depurated nymphs (i.e., less apparent distance between coordinates of depurated nymphs compared with non-depurated nymphs). Limiting the data set to only constituents of interest or bioaccumulative elements in the PCA revealed similar spatial trends (results not shown). Furthermore, even when the PCA was performed separately on the nymph subgroups (e.g., by depuration treatment or year), the spatial trends depicted remained relatively consistent across all data sets (results not shown).

The results of the PCA generally showed a strong gradient related to element concentrations. The gradient from highest to lowest concentrations was evident in the PCA plot (Fig. 15), beginning in the upper left quadrant and ending near Axis 2 in the lower left and right quadrants. ERM 1.0, where concentrations of many of the elements were highest, was clearly separated from other sites in the plot of the PCA results, while the sites with somewhat lower concentrations, ERM 2.0, CRM 3.5, and CRM 1.5, were generally more closely grouped in the PCA plot.

Evaluation of the PCA loadings (i.e., correlation coefficients) for the elements indicated that the only constituent of concern and bioaccumulative element not exceeding a loading of 0.7 (either positive or negative) on Axis 1 was $\mathrm{Hg}$ (Table 5). Therefore, all elements were considered good candidates for further analysis. 


\subsubsection{Element-Specific Results}

Mean concentrations for all elements in depurated and non-depurated mayfly nymphs samples are presented in Figs. 16 - 29, and Appendix B, Tables B.1-B.3. Based on PCA results and trends evident in plots of the individual element, concentrations of the elements $\mathrm{Al}, \mathrm{As}, \mathrm{Ba}, \mathrm{B}, \mathrm{Cr}, \mathrm{Co}, \mathrm{Cu}, \mathrm{Pb}, \mathrm{Hg}, \mathrm{Mo}, \mathrm{Ni}$, $\mathrm{Se}, \mathrm{Sr}, \mathrm{Tl}, \mathrm{V}$, and $\mathrm{Zn}$ appeared to have a possible association with either the ash spill, an alternative source, or were considered bioaccumulative constituents of concern.

\section{Principal Components Analysis - Mayfly Nymphs 2009-2010}

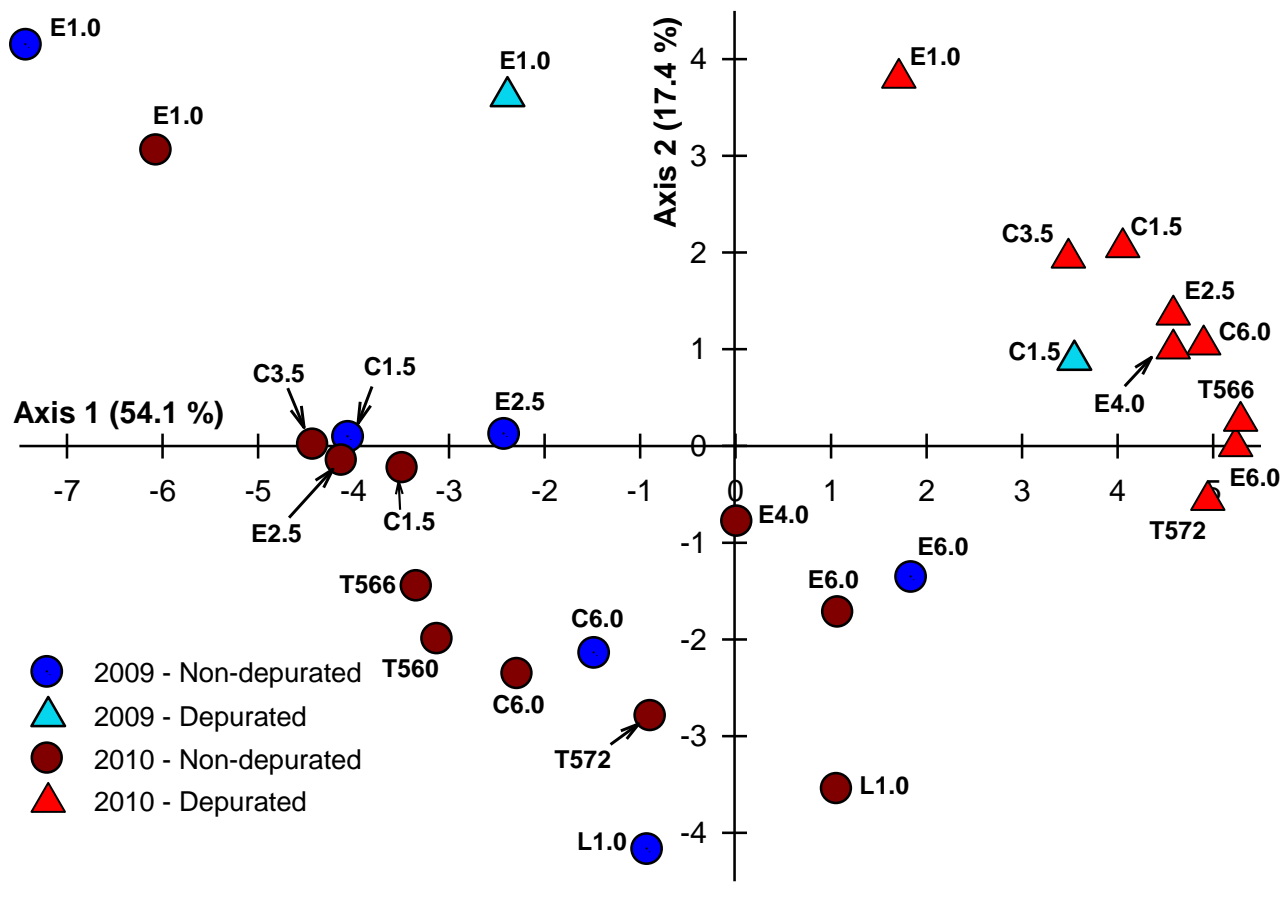

Fig. 15. Principal components analysis plots for mayfly nymph bioaccumulation results in 2009 and 2010. Mean values of all elements for each site and sample year were used in the analysis, and each symbol represents an integrated response for the elements. See Fig. 2 for description of symbol labels and PCA plot. 
Table 5. Principal component analysis loadings (i.e., correlation coefficients which range from -1.0 to 1.0) for elements in mayfly nymphs. Loadings from the PCAs that included the full suite of elements are shown, and only the loadings from the first axis (Axis 1) that were $\geq 0.7$ (both negative and positive) are included. A "_“ in front of an element indicates a negative loading, otherwise, loadings are positive.

All elements not considered essential macro-elements (i.e., $\mathrm{Ca}, \mathrm{Mg}, \mathrm{K}, \mathrm{Na}$ ) were considered good candidates for additional statistical analyses. Elements underlined were important in both depurated and non-depurated mayfly nymphs.

\begin{tabular}{|c|c|c|c|c|}
\hline Analysis & $\begin{array}{l}\text { Percent of variance } \\
\text { explained by Axis } 1\end{array}$ & Loadings $>0.9$ & Loadings $0.8-0.9$ & Loadings $0.7-0.8$ \\
\hline Entire data set & $54.1 \%$ & $\begin{array}{l}-\mathrm{Al},-\mathrm{Ba},-\mathrm{Be}, \\
-\mathrm{Cr},-\mathrm{Co},-\mathrm{Pb}, \\
\text {-Ni, -V }\end{array}$ & $\begin{array}{c}-\mathrm{Sb},-\mathrm{B},-\mathrm{Fe},-\mathrm{Sr}, \\
-\mathrm{Tl}\end{array}$ & None \\
\hline $\begin{array}{l}\text { Depurated and } \\
\text { non-depurated, } \\
2010\end{array}$ & $60.1 \%$ & $\begin{array}{c}\text {-Al, -Ba, -Be, } \\
\text {-Cr, -Co, -Fe, } \\
-\mathrm{Pb},-\mathrm{Ni},-\mathrm{Tl},-\mathrm{V}\end{array}$ & $-\mathrm{Sb},-\mathrm{B}, \mathrm{K},-\mathrm{Sr}$ & $-\mathrm{Mg},-\mathrm{Mn}, \mathrm{Zn}$ \\
\hline $\begin{array}{l}\text { Non-depurated, } \\
2009 \text { and } 2010\end{array}$ & $55.1 \%$ & $\begin{array}{c}-\mathrm{Sb},-\mathrm{Ba},-\mathrm{Be} \\
-\mathrm{Cr},-\mathrm{Sr},-\mathrm{Tl},-\mathrm{Tl}, \\
-\mathrm{V}\end{array}$ & $\begin{array}{l}-\mathrm{Al},-\mathrm{As},-\mathrm{B},-\mathrm{Cu} \\
-\mathrm{Pb},-\mathrm{Mo},-\mathrm{Ni},-\mathrm{Se}\end{array}$ & None \\
\hline $\begin{array}{l}\text { Non-depurated, } \\
2010 \text { only }\end{array}$ & $54.0 \%$ & $\begin{array}{c}\underline{-\mathrm{Sb}},-\underline{\mathrm{Ba}},-\underline{-\mathrm{Be}}, \\
-\underline{\mathrm{Cr}},-\mathrm{Se},-\underline{-\mathrm{Sr}},-\underline{\mathrm{Tl}}, \\
-\underline{\mathrm{V}}\end{array}$ & $-\mathrm{B},-\mathrm{Cu},-\underline{\mathrm{Mo}},-\underline{-\mathrm{Ni}}$ & 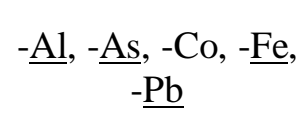 \\
\hline $\begin{array}{l}\text { Depurated, } 2010 \\
\text { only }\end{array}$ & $50.7 \%$ & $\begin{array}{l}\underline{-\mathrm{Sb}},-\underline{-\overline{\mathrm{As}}},-\mathrm{Ba}, \\
-\underline{\mathrm{Be}},-\underline{\mathrm{Cr}},-\underline{-\mathrm{Ni}},= \\
\underline{\mathrm{Sr}},-\underline{-\mathrm{Tl}},-\underline{-\mathrm{V}}\end{array}$ & $-\underline{\mathrm{Al}},-\underline{\mathrm{Fe}},-\underline{\mathrm{Mo}}$ & $-\underline{P b}$ \\
\hline
\end{tabular}



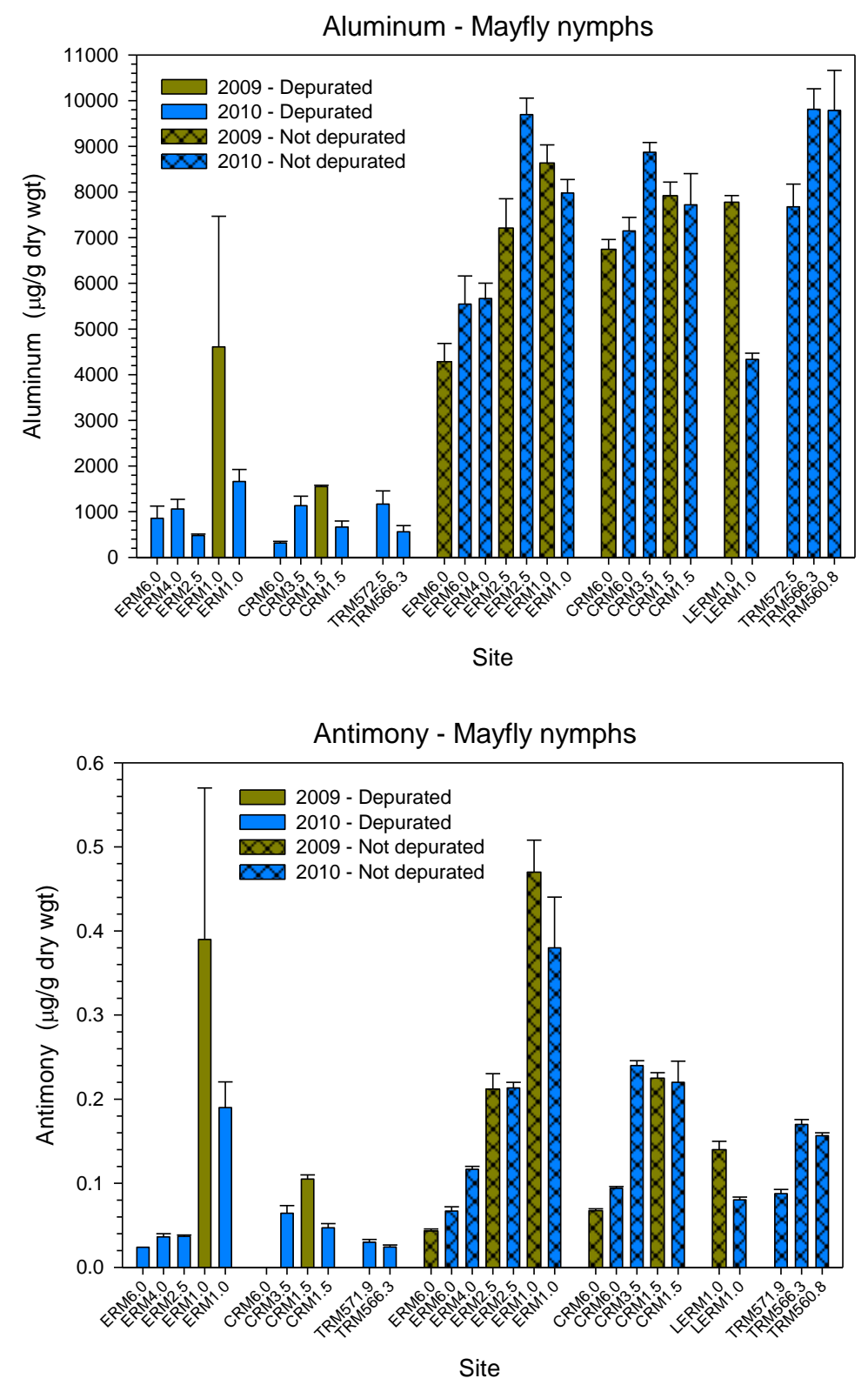

Fig. 16. Mean concentrations of aluminum (top) and antimony (bottom) in mayfly nymphs (Hexagenia bilineata) from sites in the Emory River, Clinch River, Tennessee River, and Little Emory River, 2009-2010. Values are means \pm 1 SE. 

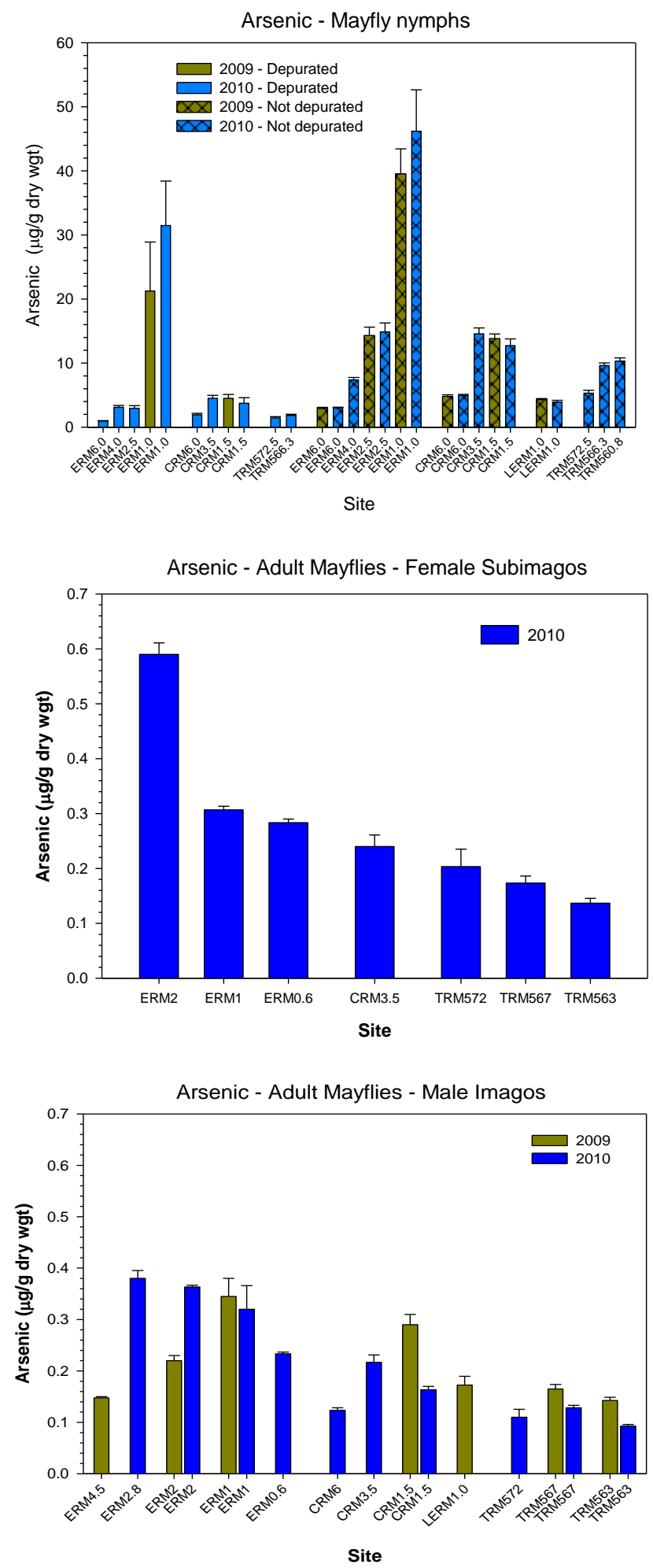

Fig. 17. Mean concentration of arsenic in mayfly nymphs (top), mayfly adult female subimagos (middle) and mayfly adult male imagos (bottom) (Hexagenia bilineata) from sites in the Emory River, Clinch River, Tennessee River, and Little Emory River, 2009-2010. Values are means $\pm 1 \mathrm{SE}$. 

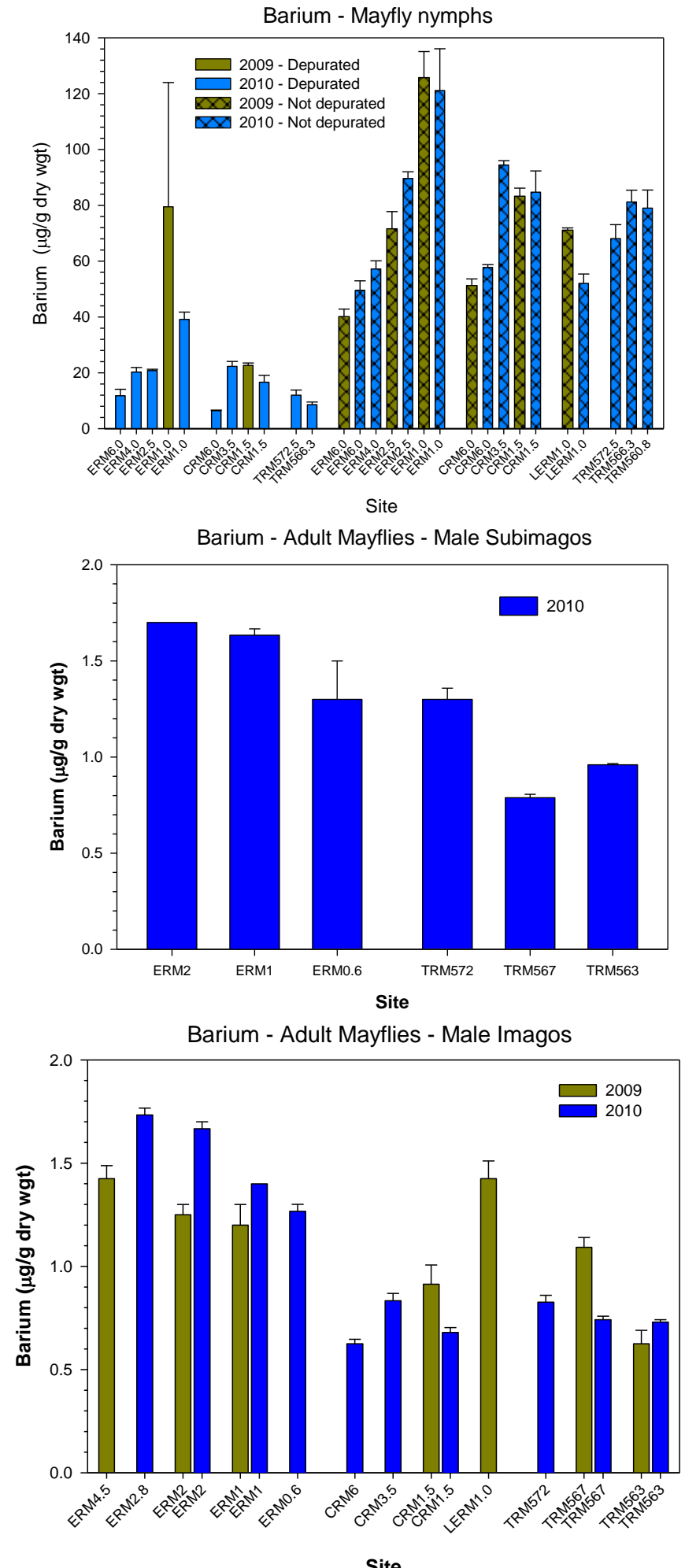

Fig. 18. Mean concentration of barium in mayfly nymphs (top), mayfly adult female subimagos (middle) and mayfly adult male imagos (bottom) (Hexagenia bilineata) from sites in the Emory River, Clinch River, Tennessee River, and Little Emory River, 2009-2010. Values are means \pm 1 SE. 

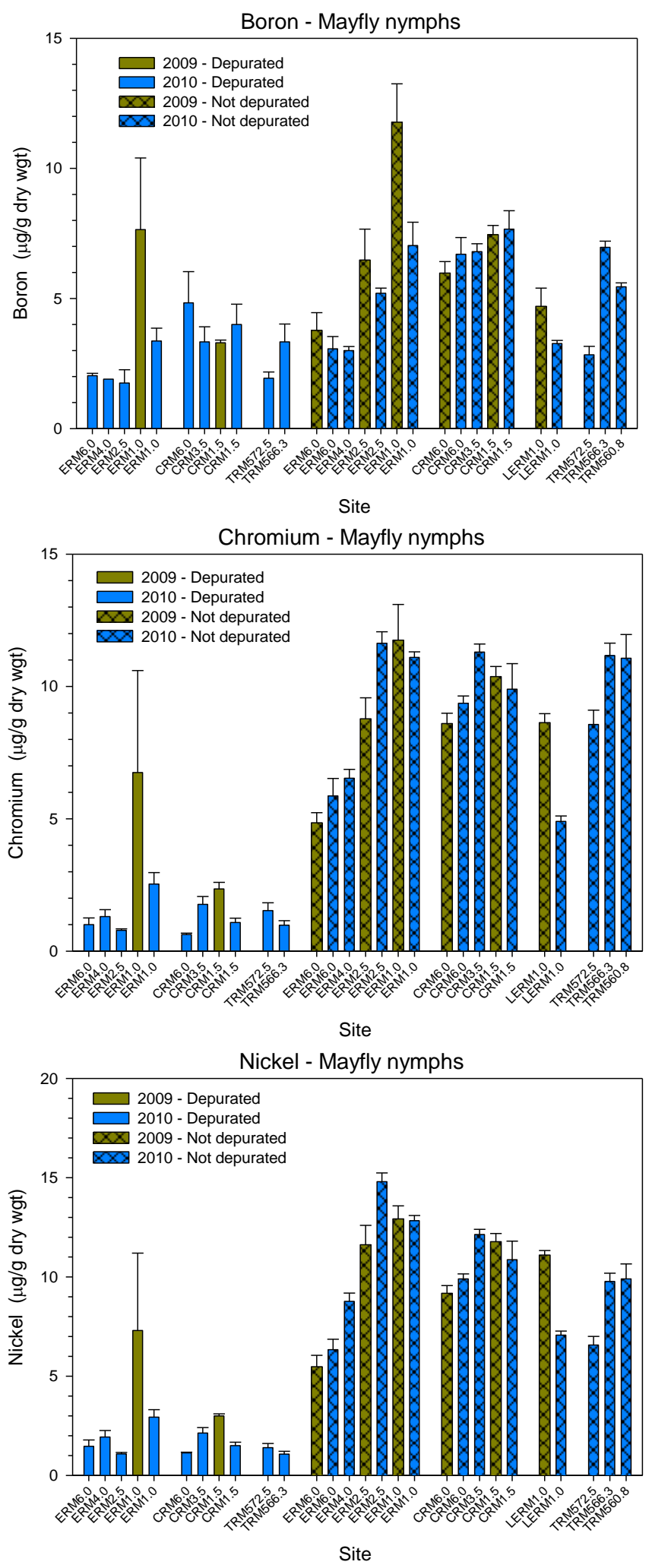

Fig. 19. Mean concentrations of boron (top), chromium (middle), and nickel (bottom) in mayfly nymphs (Hexagenia bilineata) from sites in the Emory River, Clinch River, Tennessee River, and Little Emory River, 2009-2010. Values are means $\pm 1 \mathrm{SE}$. 

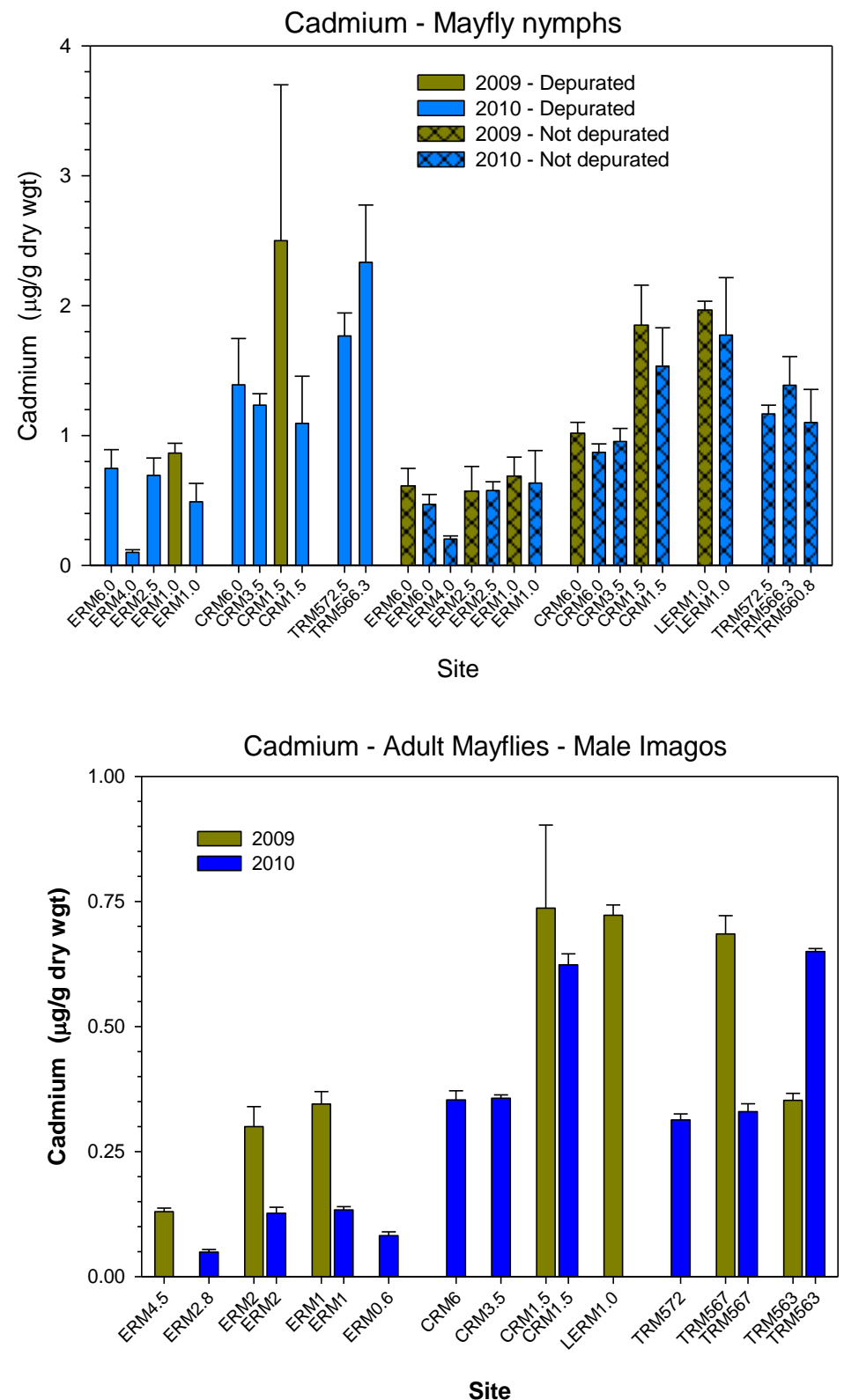

Fig. 20. Mean concentration of cadmium in mayfly nymphs (top) and mayfly adult male imagos (bottom) (Hexagenia bilineata) from sites in the Emory River, Clinch River, Tennessee River, and Little Emory River, 2009-2010. Values are means \pm 1 SE. 


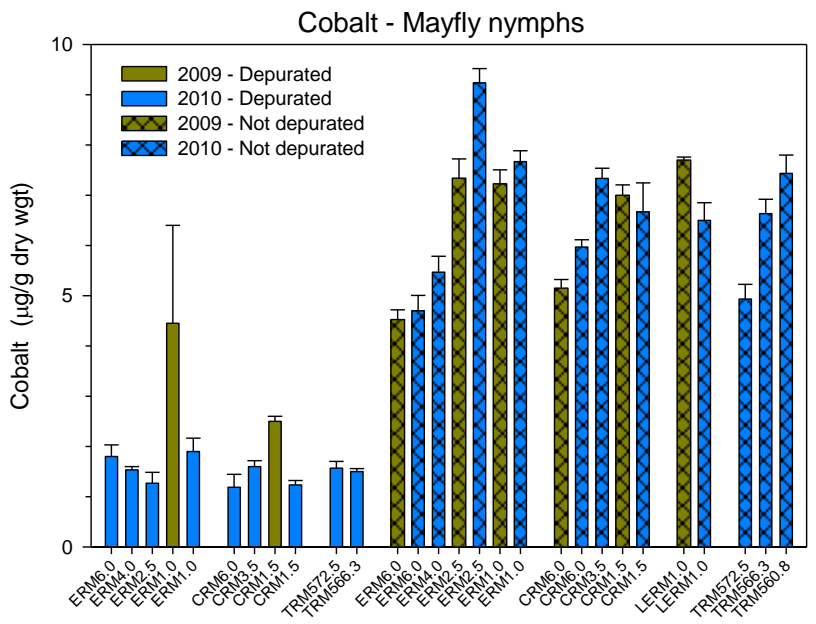

Site
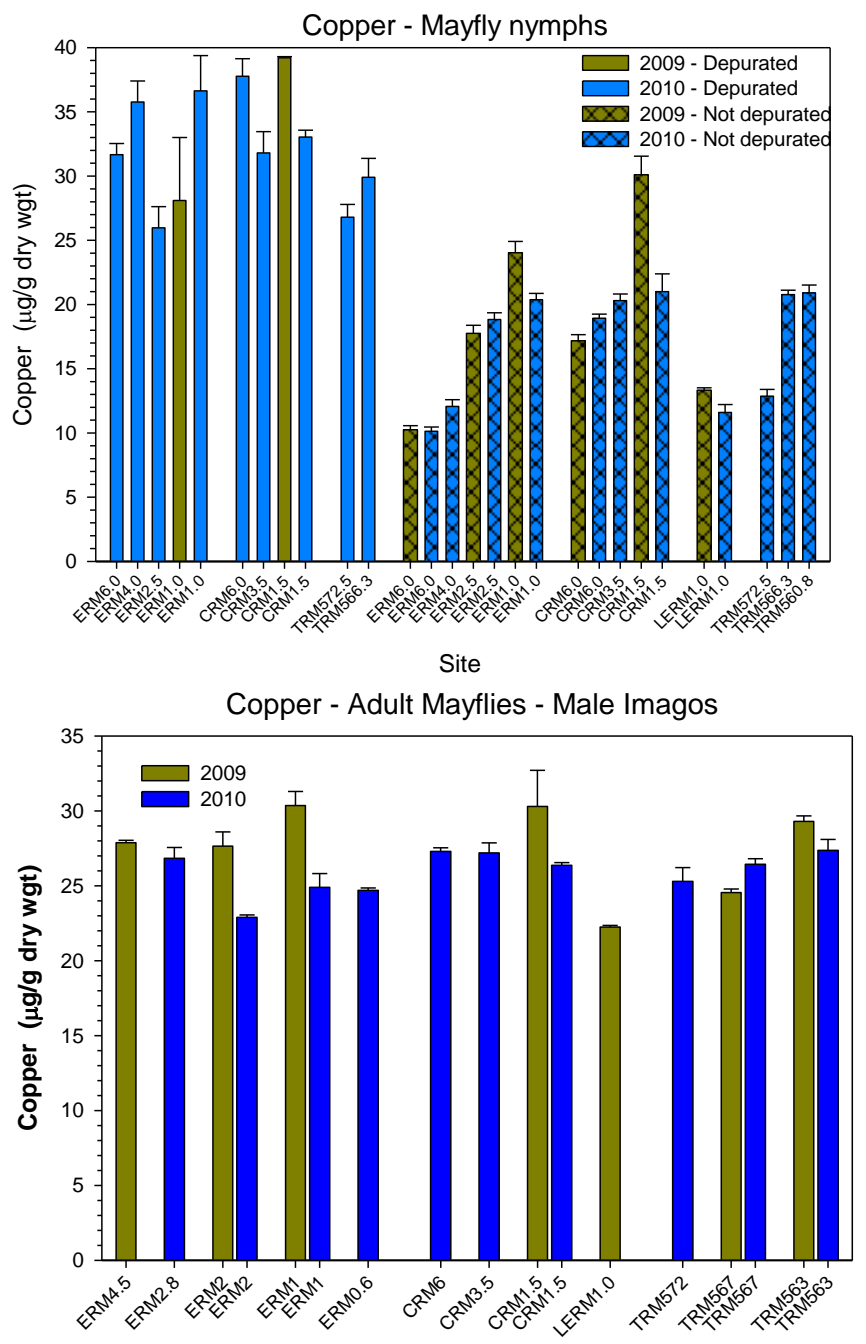

Site

Fig. 21. Mean concentration of cobalt in mayfly nymphs (top), and mean concentrations of copper in mayfly nymphs (middle) and mayfly adult male imagos (bottom) (Hexagenia bilineata) from sites in the Emory River, Clinch River, Tennessee River, and Little Emory River, 2009-2010. Values are means $\pm 1 \mathrm{SE}$. 

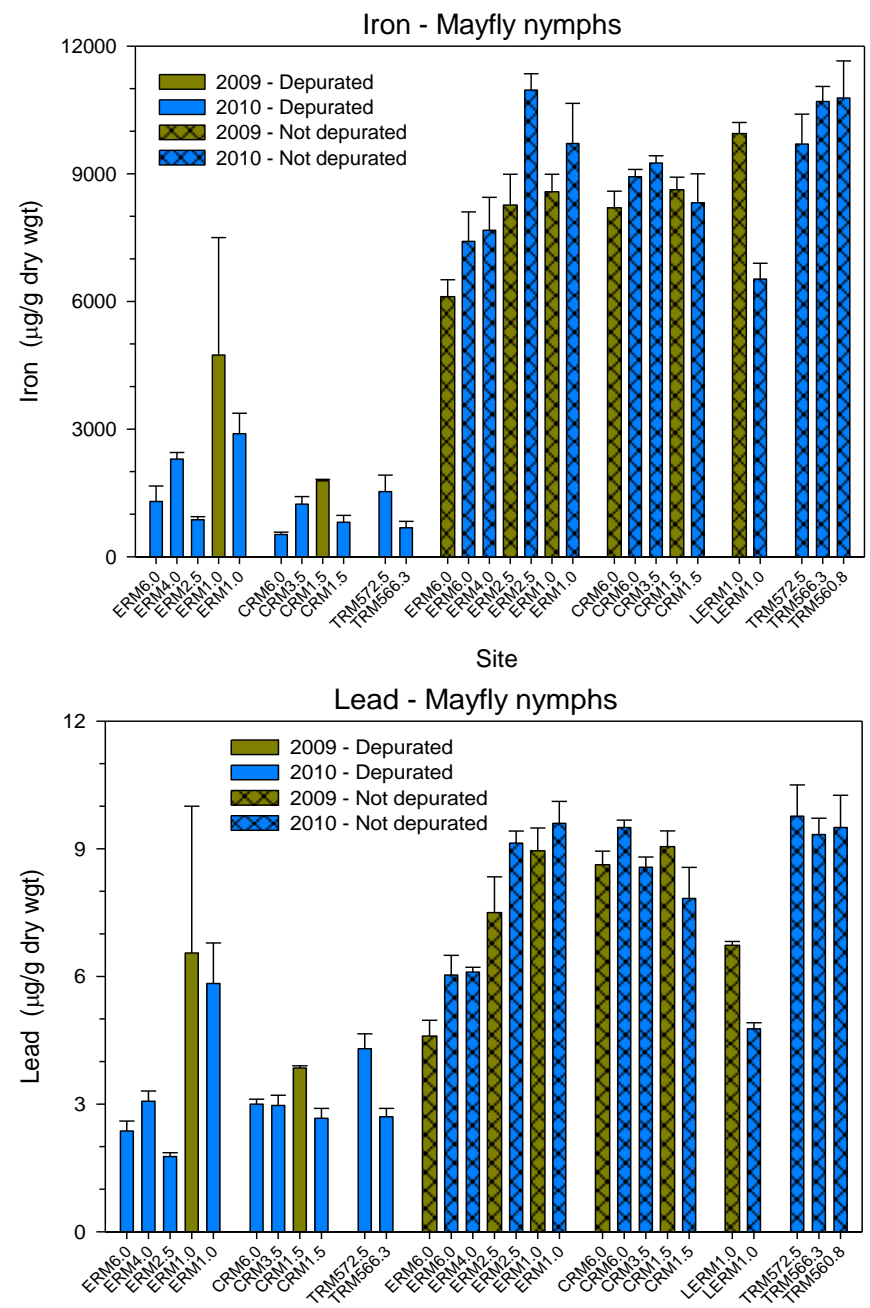

Site

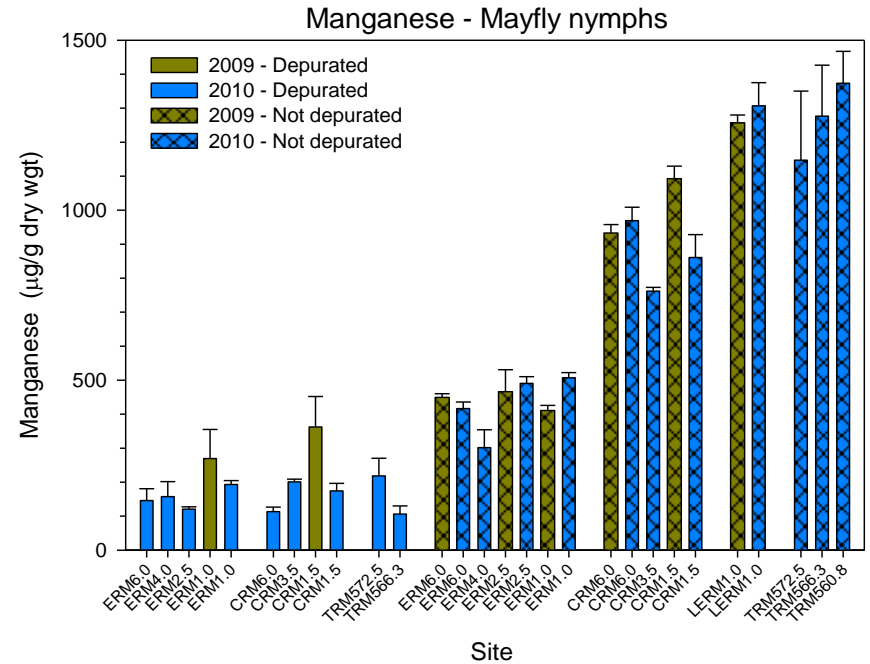

Fig. 22. Mean concentrations of iron (top), lead (middle), and manganese (bottom) in mayfly nymphs (Hexagenia bilineata) from sites in the Emory River, Clinch River, Tennessee River, and Little Emory River, 2009-2010. Values are means \pm 1 SE. 

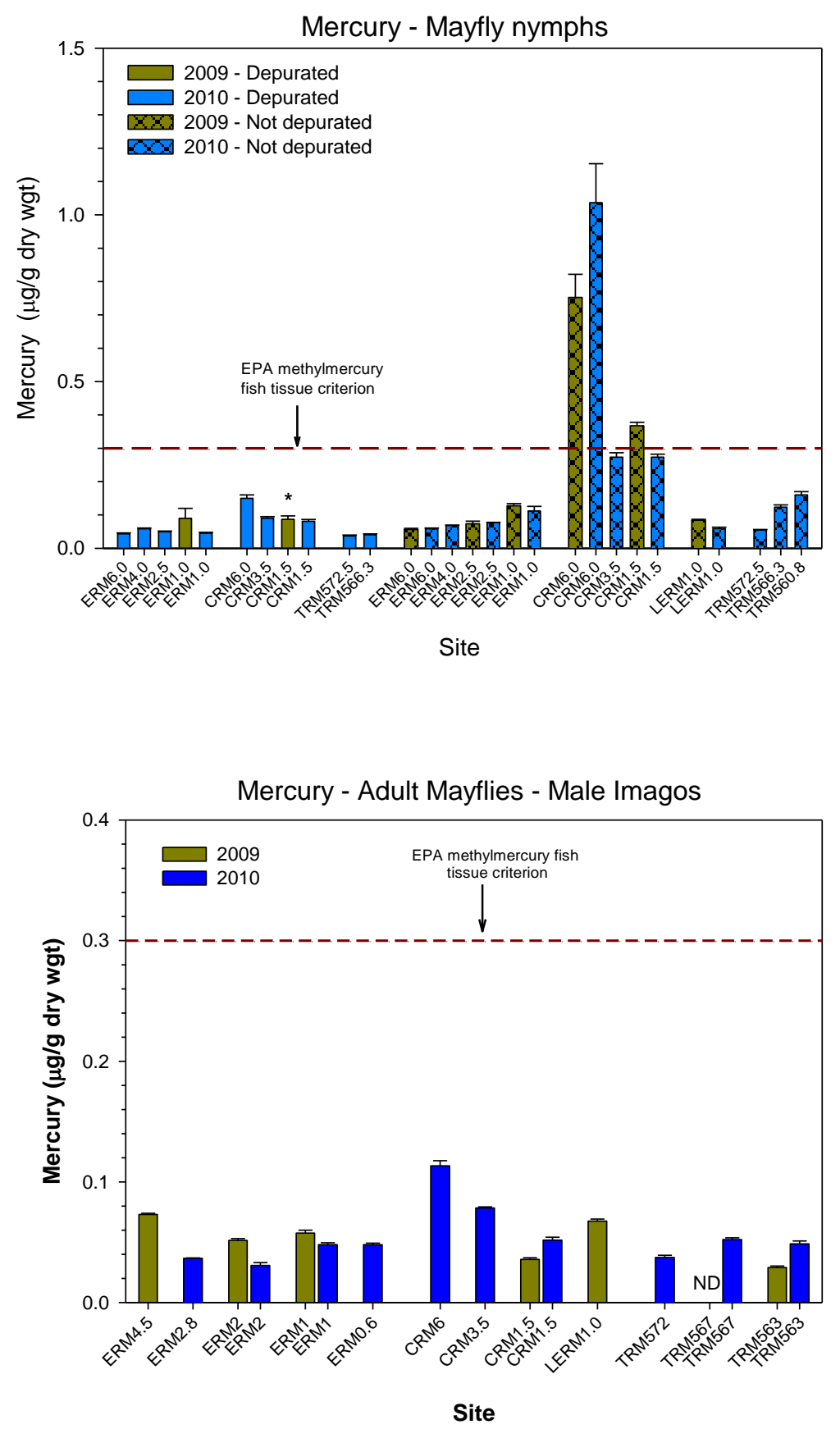

Fig. 23. Mean concentration of mercury in mayfly nymphs (top) and mayfly adult male imagos (bottom) (Hexagenia bilineata) from sites in the Emory River, Clinch River, Tennessee River, and Little Emory River, 2009-2010. Values are means \pm 1 SE. Horizontal line for mercury shows EPA's methylmercury fish tissue criterion for reference. 

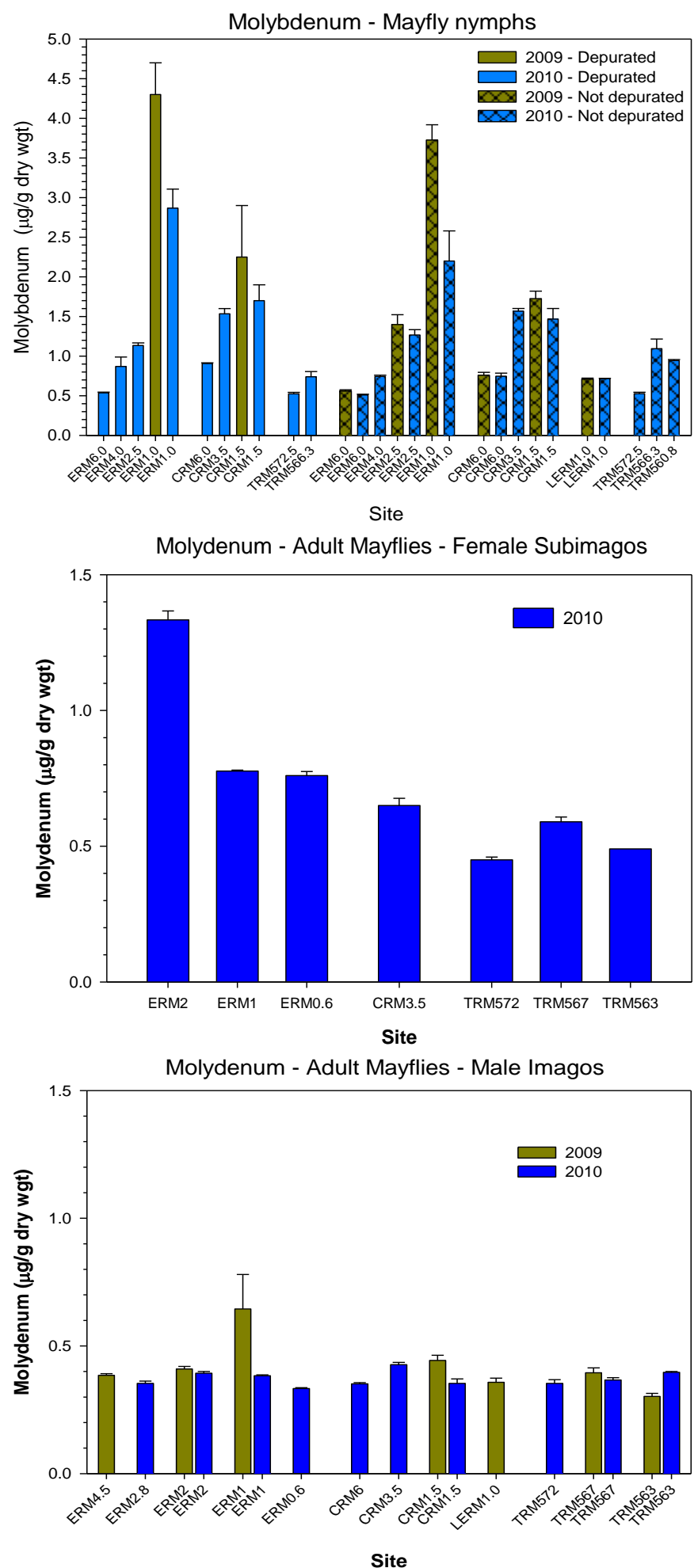

Fig. 24. Mean concentration of molybdenum in mayfly nymphs (top), mayfly adult female subimagos (middle) and mayfly adult male imagos (bottom) (Hexagenia bilineata) from sites in the Emory River, Clinch River, Tennessee River, and Little Emory River, 2009-2010. Values are means $\pm 1 \mathrm{SE}$. 


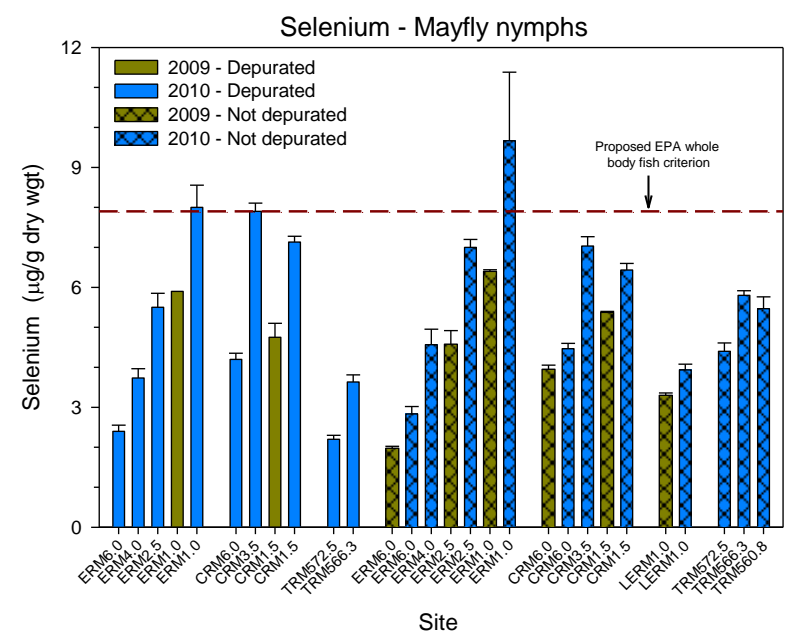

Selenium - Adult Mayflies - Female Subimagos and Imagos Pooled
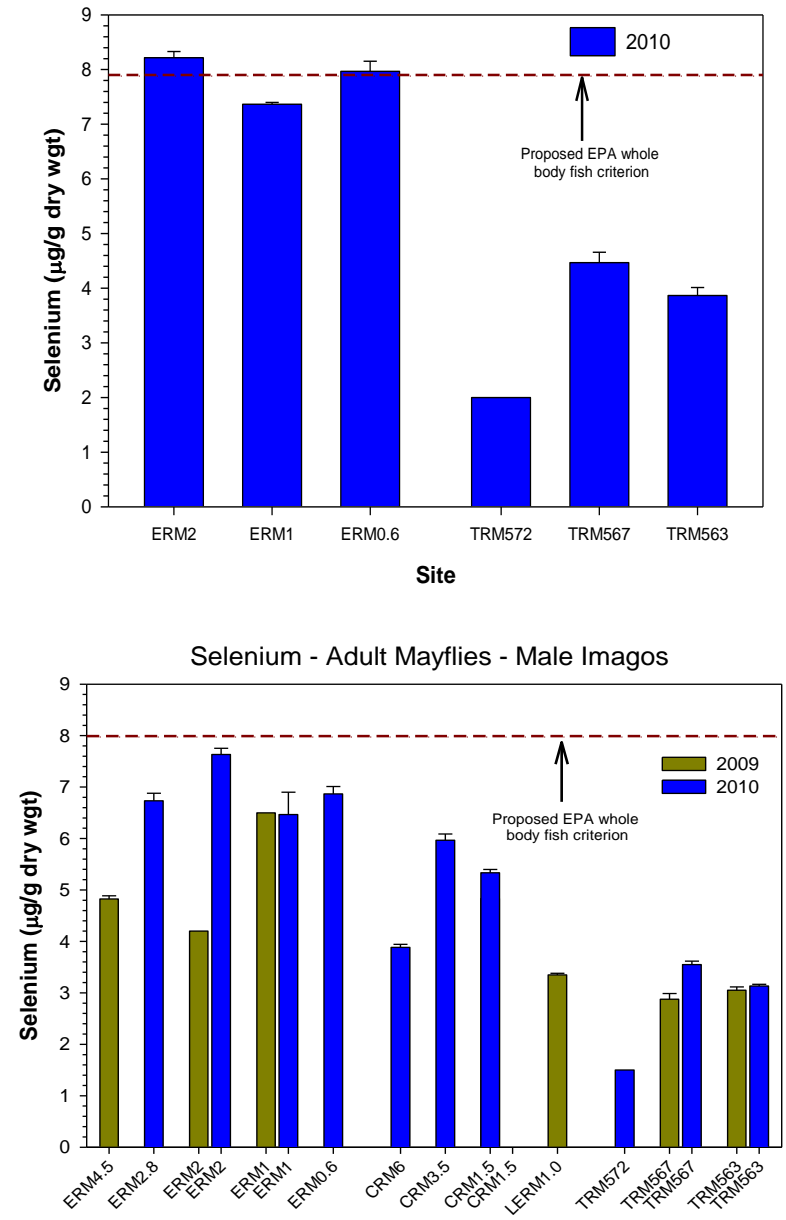

Site

Fig. 25. Mean concentration of selenium in mayfly nymphs (top), mayfly adult female subimagos (middle) and mayfly adult male imagos (bottom) (Hexagenia bilineata) from sites in the Emory River, Clinch River, Tennessee River, and Little Emory River, 2009-2010. Values are means \pm 1 SE. Horizontal line for selenium shows the proposed EPA whole body fish criterion for reference. 

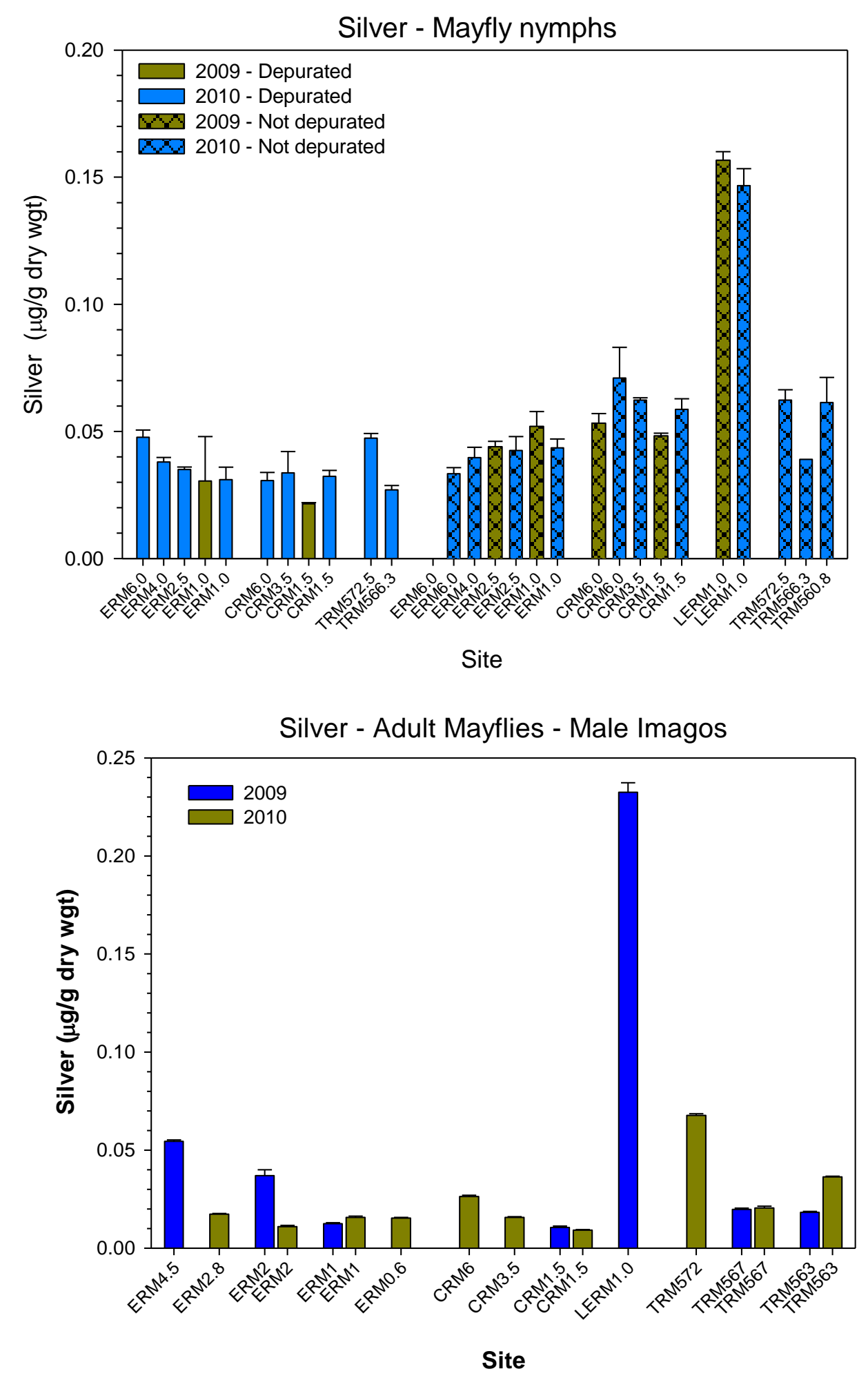

Fig. 26. Mean concentration of silver in mayfly nymphs (top) and mayfly adult male imagos (bottom) (Hexagenia bilineata) from sites in the Emory River, Clinch River, Tennessee River, and Little Emory River, 2009-2010. Values are means \pm 1 SE. 

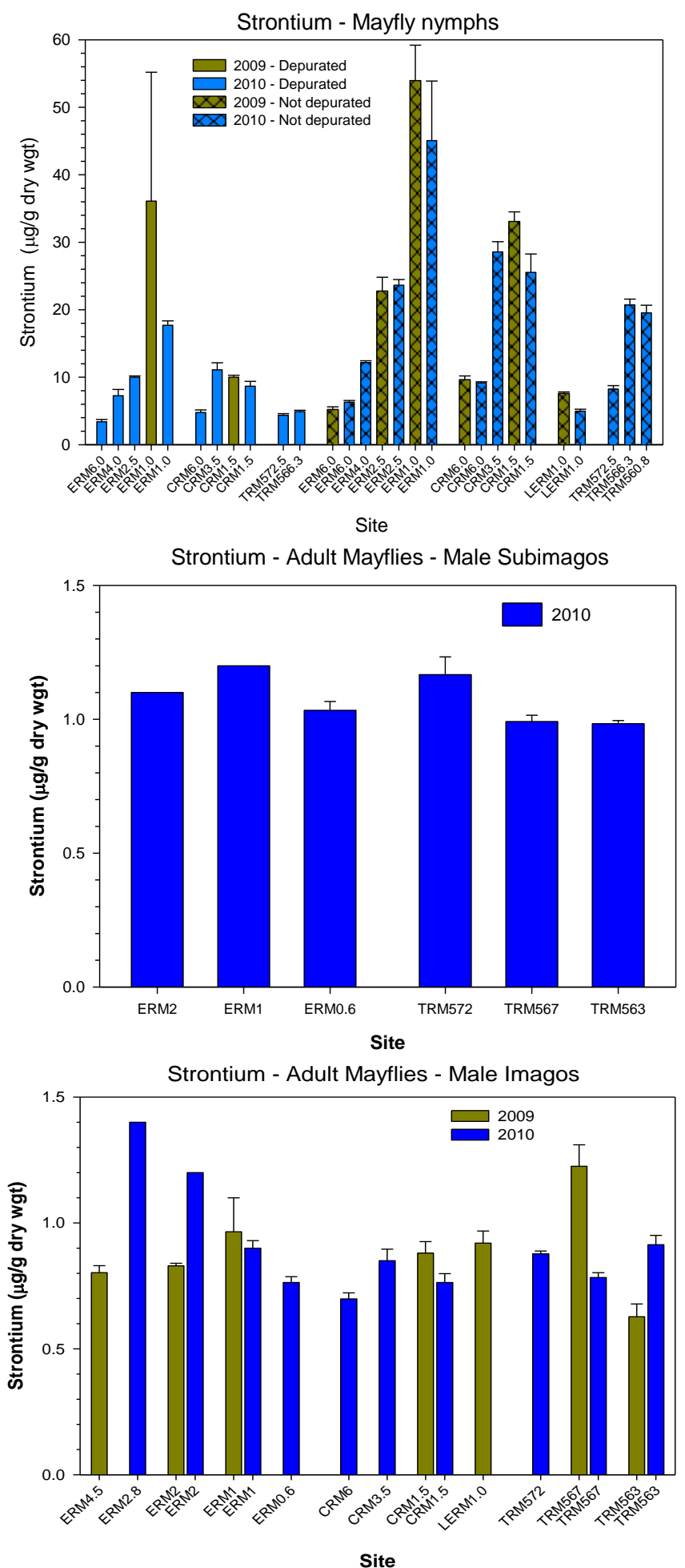

Fig. 27. Mean concentration of strontium in mayfly nymphs (top), mayfly adult female subimagos (middle) and mayfly adult male imagos (bottom) (Hexagenia bilineata) from sites in the Emory River, Clinch River, Tennessee River, and Little Emory River, 2009-2010.

Values are means \pm 1 SE. 

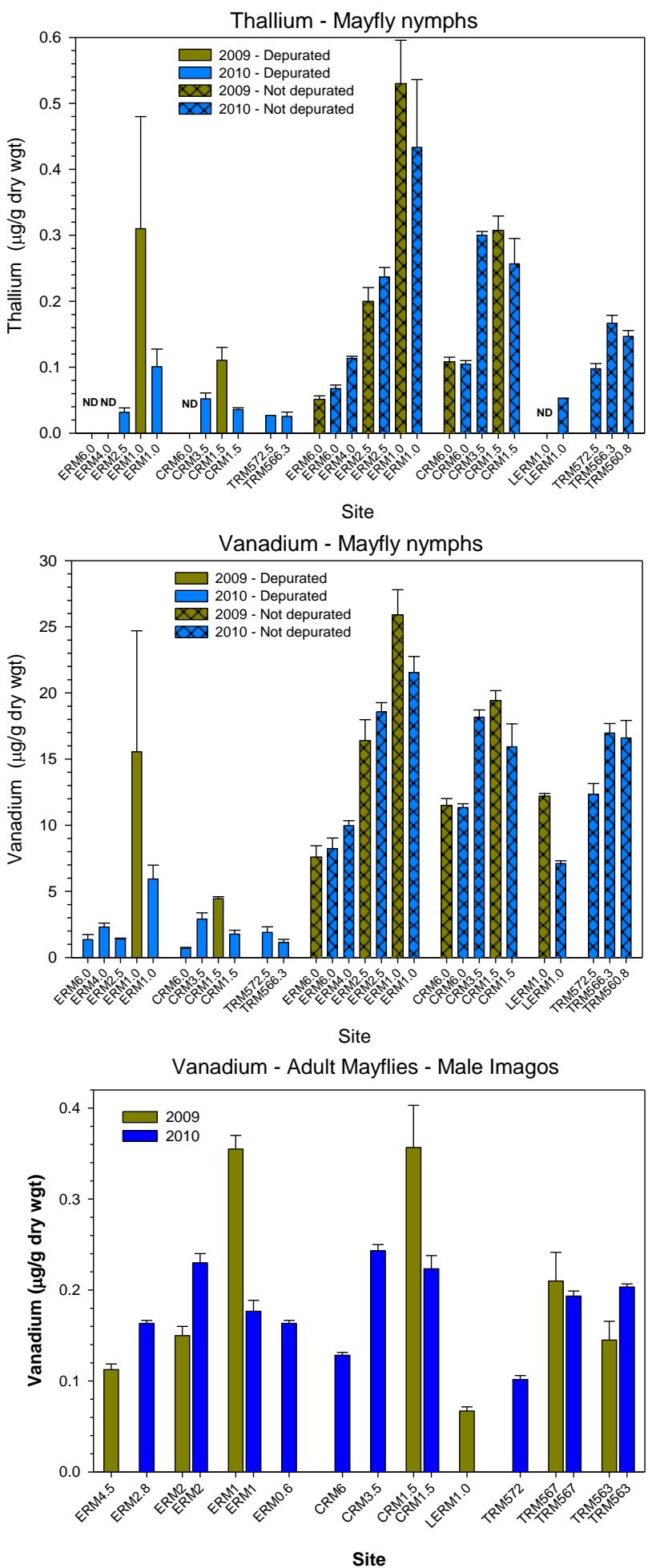

Fig. 28. Mean concentration of thallium in mayfly nymphs (top), and mean concentrations of vanadium in mayfly nymphs (middle) and mayfly adult male imagos (bottom) (Hexagenia bilineata) from sites in the Emory River, Clinch River, Tennessee River, and Little Emory River, 2009-2010. Values are means $\pm 1 \mathrm{SE}$. 

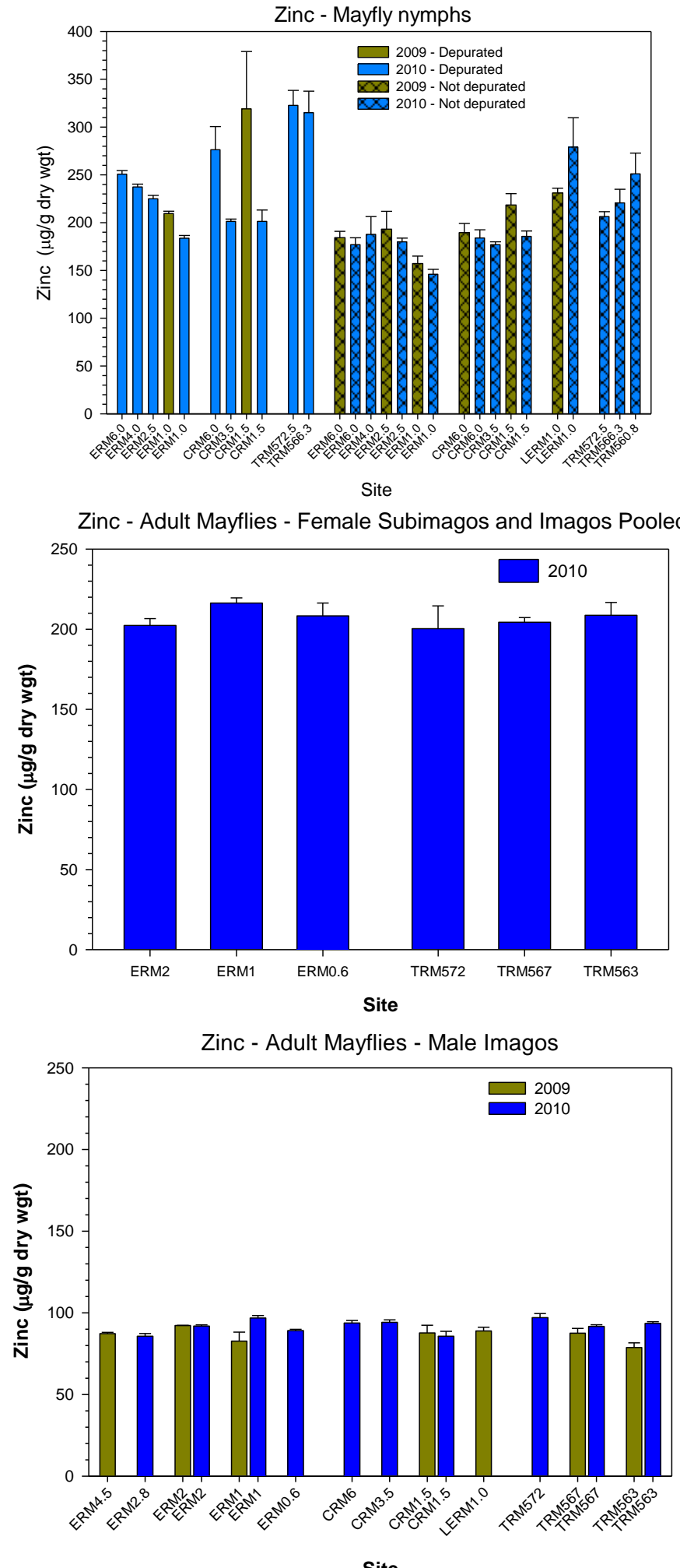

Fig. 29. Mean concentration of zinc in mayfly nymphs (top), mayfly adult female subimagos (middle) and mayfly adult male imagos (bottom) (Hexagenia bilineata) from sites in the Emory River, Clinch River, Tennessee River, and Little Emory River, 2009-2010. Values are means \pm 1 SE. 
Effect of depuration - Depuration had a strong and clear effect on the concentrations of most elements. Of the 16 elements evaluated, only Mo showed no apparent difference between depurated and non-depurated nymphs (Table 6, Fig. 24). As for the snails, $\mathrm{Cu}$ was clearly higher in depurated than nondepurated nymphs (Fig. 21). While the differences in concentrations of Zn between depurated and nondepurated nymphs was more subtle, they were still higher than in nymphs that had not been depurated (Fig. 29). The concentrations of the remaining 13 elements evaluated were all lower in depurated than non-depurated nymphs (Figs. 16-20, 22, 23, 25-28). As suggested by the interaction term for site and depuration effect in the 2-way ANOVA (Table 6) and the concentration plots for these elements, the magnitude of difference between depurated and non-depurated nymphs was not consistent across sites for all elements. Of particular note, Se concentrations were generally lower in depurated than non-depurated nymphs at all sites in the Emory River, CRM 6.0 and TRM 572.5 in 2010, but at CRM 1.5, CRM 3.5 and TRM 566.3 concentrations were actually higher in depurated nymphs (Fig. 25). This suggests that a greater proportion of the Se was associated with tissues of nymphs from CRM 1.5, CRM 3.5, and TRM 566.3 , while the at the other sites a greater proportion of the Se was associated with undigested food particles.

Spatial and temporal trends - Like the snails, site differences were found in concentrations of virtually every element analyzed, but the spatial trends exhibited by the nymphs were much less ambiguous (Table 6, Figs. 16 -29). The only elements showing no apparent association with fly ash were $\mathrm{Cd}, \mathrm{Mn}, \mathrm{Hg}$, Ag, and Zn (Figs. 20, 22, 26, and 29). The source of $\mathrm{Hg}$ was clearly the Clinch River, where concentrations in depurated nymphs from CRM 6.0 were at least 2.5 times higher than in depurated nymphs from all Emory River and Tennessee River sites in 2010, and in non-depurated nymphs at least 6 times and 8.5 times higher in 2009 and 2010 respectively (Fig. 23). Relative to other sites, concentrations of Cd were elevated at CRM 1.5 in non-depurated nymphs in 2009 and 2010, but concentrations of Cd were also higher at LERM 1.0 than at all Emory River sites in both years (Fig. 20). In depurated nymphs, highest concentrations of Cd were found at TRM 566.3 and TRM 572.5 in 2010, followed by the Clinch River sites where a trend of decreasing concentrations with distance downstream from CRM 6.0 was present. Some of the lowest concentrations of Ag were found at ERM 2.5 and ERM 1.0 in non-depurated nymphs in both 2009 and 2010, while concentrations of Ag at LERM 1.0 were $~ 2$ to 4 times higher than at all other sites in both years. Manganese concentrations in non-depurated nymphs suggested a likely association with river and not anthropogenic inputs, with lowest concentrations in nymphs from the Emory River, and highest concentrations in nymphs from LERM 1.0 and Tennessee River sites (Fig. 22). Finally, Zn concentrations where generally highest in nymphs at reference sites in both years (Fig. 29).

Concentrations of the elements $\mathrm{Sb}, \mathrm{As}, \mathrm{Ba}, \mathrm{Mo}, \mathrm{Se}, \mathrm{Sr}, \mathrm{Tl}$, and $\mathrm{V}$ exhibited some of the strongest spatial trends in mayfly nymphs suggesting a possible association with fly ash (Table 6, Figs. 16-18, 24, 25, 28 and 29). Maximum concentrations of these elements in both groups of nymphs were generally present at ERM 1.0, while lower concentrations of these elements were found at CRM 3.5, CRM 1.5, and ERM 2.5, where there often appeared to be little difference among the sites. Compared with TRM 572.5, concentrations of these elements also appeared to be elevated at TRM 566.3 and TRM 560.8 in nondepurated nymphs, but not in depurated nymphs from ERM 566.3 (only non-depurated nymphs from TRM 560.3 were analyzed). Concentrations of Mo, Se, and Sr, and to a lesser extent As and Ba, appeared to be slightly elevated at ERM 4.0 in both the depurated and non-depurated nymphs. The results 
Table 6. Summary results for ANOVAs performed on individual elements in mayfly nymphs.

\begin{tabular}{|c|c|c|c|c|c|}
\hline Element & Model tested $^{1}$ & Model terms & $\mathrm{DF}^{2}$ & F-value & P-value \\
\hline \multirow{7}{*}{ Arsenic } & One-way (site) & Site & 10,32 & 96.15 & $<0.001$ \\
\hline & \multirow{3}{*}{$\begin{array}{l}\text { Two-way } \\
\text { (site x year) }\end{array}$} & Site & 5,41 & 260.03 .62 & $<0.001$ \\
\hline & & Year & 1,41 & 0.10 & 0.758 \\
\hline & & Site $\mathrm{x}$ year & 5,41 & 0.58 & 0.716 \\
\hline & \multirow{3}{*}{$\begin{array}{l}\text { Two-way } \\
\text { (site x depuration) }\end{array}$} & Site & 8,53 & 104.24 & $<0.001$ \\
\hline & & Depuration & 1,53 & 362.84 & $<0.001$ \\
\hline & & Site $\mathrm{x}$ depuration & 8,53 & 4.82 & $<0.001$ \\
\hline \multirow{4}{*}{ Barium } & One-way (site) & Site & 10,32 & 15.18 & $<0.001$ \\
\hline & \multirow{3}{*}{$\begin{array}{l}\text { Two-way } \\
\text { (site x year) }\end{array}$} & Site & 5,41 & 50.08 & $<0.001$ \\
\hline & & Year & 1,41 & 0.77 & 0.389 \\
\hline & & Site $\mathrm{x}$ year & 5,41 & 3.81 & 0.009 \\
\hline \multirow{7}{*}{ Boron } & One-way (site) & Site & 10,30 & 20.61 & $<0.001$ \\
\hline & \multirow{3}{*}{$\begin{array}{l}\text { Two-way } \\
\text { (site x year) }\end{array}$} & Site & 5,39 & 11.76 & $<0.001$ \\
\hline & & Year & 1,39 & 4.94 & 0.034 \\
\hline & & Site $\mathrm{x}$ year & 5,39 & 2.33 & 0.069 \\
\hline & \multirow{3}{*}{$\begin{array}{l}\text { Two-way } \\
\text { (site } \mathrm{x} \text { depuration) }\end{array}$} & Site & 8,50 & 11.05 & $<0.001$ \\
\hline & & Depuration & 1,50 & 70.59 & $<0.001$ \\
\hline & & Site $\mathrm{x}$ depuration & 8,50 & 1.34 & 0.260 \\
\hline \multirow{4}{*}{ Chromium } & One-way (site) & Site & 10,32 & 22.14 & $<0.001$ \\
\hline & \multirow{3}{*}{$\begin{array}{l}\text { Two-way } \\
\text { (site x year) }\end{array}$} & Site & 5,39 & 28.78 & $<0.001$ \\
\hline & & Year & 1,39 & 0.01 & 0.916 \\
\hline & & Site $\mathrm{x}$ year & 5,39 & 6.87 & $<0.001$ \\
\hline \multirow{4}{*}{ Cobalt } & One-way (site) & Site & 10,32 & 16.73 & $<0.001$ \\
\hline & \multirow{3}{*}{$\begin{array}{l}\text { Two-way } \\
\text { (site x year) }\end{array}$} & Site & 5,41 & 40.14 & $<0.001$ \\
\hline & & Year & 1,41 & 2.92 & 0.098 \\
\hline & & Site $\mathrm{x}$ year & 5,41 & 5.98 & $<0.001$ \\
\hline \multirow{4}{*}{ Copper } & One-way (site) & Site & 10,32 & 57.67 & $<0.001$ \\
\hline & \multirow{3}{*}{$\begin{array}{l}\text { Two-way } \\
\text { (site x year) }\end{array}$} & Site & 5,41 & 157.76 & $<0.001$ \\
\hline & & Year & 1,41 & 15.63 & $<0.001$ \\
\hline & & Site $\mathrm{x}$ year & 5,41 & 10.44 & $<0.001$ \\
\hline \multirow{4}{*}{ Lead } & One-way (site) & Site & 10,32 & 17.89 & $<0.001$ \\
\hline & \multirow{3}{*}{$\begin{array}{l}\text { Two-way } \\
\text { (site x year) }\end{array}$} & Site & 5,41 & 20.30 & $<0.001$ \\
\hline & & Year & 1,41 & 0.58 & 0.452 \\
\hline & & Site x year & 5,41 & 3.72 & 0.01 \\
\hline \multirow{7}{*}{ Molybdenum } & One-way (site) & Site & 10,32 & 27.05 & $<0.001$ \\
\hline & \multirow{3}{*}{$\begin{array}{l}\text { Two-way } \\
\text { (site x year) }\end{array}$} & Site & 5,41 & 114.71 & $<0.001$ \\
\hline & & Year & 1,41 & 13.99 & $<0.001$ \\
\hline & & Site $\mathrm{x}$ year & 5,41 & 5.73 & $<0.001$ \\
\hline & \multirow{3}{*}{$\begin{array}{l}\text { Two-way } \\
\text { (site } \mathrm{x} \text { depuration) }\end{array}$} & Site & 8,53 & 69.47 & $<0.001$ \\
\hline & & Depuration & 1,53 & 1.04 & 0.315 \\
\hline & & Site $\mathrm{x}$ depuration & 8,53 & 2.70 & 0.019 \\
\hline \multirow{4}{*}{ Nickel } & One-way (site) & Site & 10,32 & 26.42 & $<0.001$ \\
\hline & \multirow{3}{*}{$\begin{array}{l}\text { Two-way } \\
\text { (site x year) }\end{array}$} & Site & 5,41 & 38.01 & $<0.001$ \\
\hline & & Year & 1,41 & 0.02 & 0.903 \\
\hline & & Site $\mathrm{x}$ year & 5,41 & 6.82 & $<0.001$ \\
\hline
\end{tabular}




\begin{tabular}{|c|c|c|c|c|c|}
\hline Element & Model tested $^{1}$ & Model terms & $\mathrm{DF}^{2}$ & F-value & $\mathrm{P}$-value \\
\hline \multirow{7}{*}{ Selenium } & One-way (site) & Site & 10,32 & 18.27 & $<0.001$ \\
\hline & \multirow{3}{*}{$\begin{array}{l}\text { Two-way } \\
\text { (site x year) }\end{array}$} & Site & 5,41 & 78.62 & $<0.001$ \\
\hline & & Year & 1,41 & 51.43 & $<0.001$ \\
\hline & & Site $\mathrm{x}$ year & 5,41 & 2.17 & 0.084 \\
\hline & \multirow{3}{*}{$\begin{array}{l}\text { Two-way } \\
\text { (site } \mathrm{x} \text { depuration) }\end{array}$} & Site & 8,53 & 67.35 & $<0.001$ \\
\hline & & Depuration & 1,53 & 33.21 & $<0.001$ \\
\hline & & Site $\mathrm{x}$ depuration & 8,53 & 6.30 & $<0.001$ \\
\hline \multirow{7}{*}{ Strontium } & One-way (site) & Site & 10,32 & 61.55 & $<0.001$ \\
\hline & \multirow{3}{*}{$\begin{array}{l}\text { Two-way } \\
\text { (site x year) }\end{array}$} & Site & 5,41 & 176.87 & $<0.001$ \\
\hline & & Year & 1,41 & 4.78 & 0.037 \\
\hline & & Site $\mathrm{x}$ year & 5,41 & 2.61 & 0.045 \\
\hline & \multirow{3}{*}{$\begin{array}{l}\text { Two-way } \\
\text { (site } \mathrm{x} \text { depuration) }\end{array}$} & Site & 8,53 & 88.71 & $<0.001$ \\
\hline & & Depuration & 1,53 & 430.69 & $<0.001$ \\
\hline & & Site $\mathrm{x}$ depuration & 8,53 & 6.05 & $<0.001$ \\
\hline \multirow{4}{*}{ Thallium } & One-way (site) & Site & 10,32 & 14.03 & $<0.001$ \\
\hline & \multirow{3}{*}{$\begin{array}{l}\text { Two-way } \\
\text { (site x year) }\end{array}$} & Site & 5,38 & 39.62 & $<0.001$ \\
\hline & & Year & 1,38 & 0.57 & 0.456 \\
\hline & & Site $\mathrm{x}$ year & 4,38 & 1.11 & 0.371 \\
\hline \multirow{4}{*}{ Vanadium } & One-way (site) & Site & 10,32 & 26.73 & $<0.001$ \\
\hline & \multirow{3}{*}{$\begin{array}{l}\text { Two-way } \\
\text { (site x year) }\end{array}$} & Site & 5,41 & 50.05 & $<0.001$ \\
\hline & & Year & 1,41 & 6.20 & 0.019 \\
\hline & & Site x year & 5,41 & 3.13 & 0.021 \\
\hline \multirow{6}{*}{ Zinc $^{3}$} & \multirow{3}{*}{$\begin{array}{l}\text { Two-way } \\
\text { (site x year) }\end{array}$} & Site & 5,41 & 12.42 & $<0.001$ \\
\hline & & Year & 1,41 & 0.60 & 0.443 \\
\hline & & Site $\mathrm{x}$ year & 5,41 & 1.35 & 0.270 \\
\hline & \multirow{3}{*}{$\begin{array}{l}\text { Two-way } \\
\text { (site } \mathrm{x} \text { depuration) }\end{array}$} & Site & 8,53 & 19.41 & $<0.001$ \\
\hline & & Depuration & 1,53 & 145.92 & $<0.001$ \\
\hline & & Site $\mathrm{x}$ depuration & 8,53 & 3.33 & 0.006 \\
\hline
\end{tabular}

${ }^{\mathrm{T}}$ One-way (Site) and two-way models (Site x Year) only included mayflies that had not been depurated. The analysis of site $\mathrm{x}$ depuration was not performed on elements for which graphs showed a clear effect of depuration.

${ }^{2} \mathrm{DF}=$ degrees of freedom.

${ }^{3}$ One-way ANOVA on the factor of Site for 2010 was not performed because it could be seen from plots of mean values that there was no effect from the ash spill.

for $\mathrm{Tl}$ in non-depurated nymphs and $\mathrm{V}$ in both groups of nymphs suggested that their concentrations were slightly elevated at ERM 4.0 as well.

Concentrations of the elements $\mathrm{B}, \mathrm{Cr}, \mathrm{Co}, \mathrm{Cu}$, and $\mathrm{Ni}$ in mayfly nymphs appeared to have a possible association with fly ash from KIF, but their concentrations also appeared to be influenced by other possible sources upstream of CRM 6.0 or even differences in natural background/geochemical conditions of the Clinch and Emory Rivers (Table 6, Figs. 19 and 21). The spatial trends exhibited by Cr, $\mathrm{Co}, \mathrm{Cu}$, and $\mathrm{Ni}$ in non-depurated nymphs from the Emory River were generally similar to those of other elements, but their concentrations at Clinch River sites, including CRM 6.0, were comparable to or higher than those at the Emory River sites. However, in nymphs that were depurated (2010), only $\mathrm{Cr}$ and $\mathrm{Ni}$ concentrations appeared to show a possible association with fly ash at ERM 1.0 and CRM 3.5. There was 
little difference among sites in the concentration of Co in depurated nymphs (2010), while depurated nymphs exhibited a wide range in $\mathrm{Cu}$ concentrations among reference sites and sites downstream of the ash spill. Highest concentrations of $\mathrm{Cu}$ in depurated nymphs were found at CRM 6.0 and ERM 1.0, which may indicate a source of anthropogenic inputs upstream of CRM 6.0 that could be influencing ERM 1.0, or possibly even naturally higher concentrations of $\mathrm{Cu}$ in the Clinch River watershed. Finally, spatial trends in the concentrations of B in non-depurated nymphs appeared to suggest a possible influence of fly ash at ERM 2.5 and particularly ERM 1.0, but concentrations of B in nymphs from all Clinch River sites were similar to those at ERM 2.5. Furthermore, concentrations of B in depurated nymphs at ERM 1.0 were lower than those at CRM 6.0, but similar to those at CRM 3.5 and CRM 1.5. This suggests that some of the B in nymphs from ERM 1.0 could come from a source in the Clinch River upstream of CRM 6.0 or natural geochemical sources.

Aluminum, $\mathrm{Pb}$ and $\mathrm{Fe}$ concentrations in non-depurated nymphs showed spatial trends in the Emory River that were comparable to most other elements (Table 6, Figs. 16 and 22). However, "spikes" in concentrations of $\mathrm{Al}$ and $\mathrm{Pb}$ at ERM 2.5 in 2010 may be indicative of greater consumption of clay particles by the nymphs. The highest concentrations of $\mathrm{Al}, \mathrm{Pb}$, and $\mathrm{Fe}$ in depurated nymphs were found at ERM 1.0. This could have been associated with fly ash, or because colder, and thus, more dense water from the Clinch River often flows upstream in the Emory River, the higher concentrations at ERM 1.0 could possibly be associated with anthropogenic sources upstream of CRM 6.0 (where relatively high concentrations of all three elements were found in non-depurated nymphs) or natural differences in geochemistry in both watersheds that could affect ERM 1.0.

While changes in concentrations of elements in non-depurated nymphs occurred in many elements at most sites between 2009 and 2010, there did not appear to be any regular patterns in many changes. As previously suggested, there appeared to be "spikes" in the concentrations of a few elements (e.g., Al, Fe, possibly Co and Ni) at ERM 2.5 (Figs. 16, 19, 21, and 22) in 2010 that could potentially be related to increased consumption of clay particles that may have been suspended and then deposited during the 2010 dredging operations. There did, however, appear to be a notable reduction in the concentration of $\mathrm{Cu}$, particularly at ERM 1.0 and CRM 1.5 in 2010 (Fig. 21). Similarly, the greatest reduction in the concentration of Mo appeared to occur at ERM 1.0 in 2010 (Fig. 24). Selenium concentrations, in contrast, increased considerably at many sites in 2010, particularly at ERM 1.0, ERM 2.5, and to a lesser extent at CRM 1.5 (Fig. 25).

\subsection{MAYFLY ADULTS}

\subsubsection{Principal Components Analysis}

In addition to the identification of spatial trends and helping in the selection of elements for more detailed analysis, another goal of PCA in the analyses of adult mayflies was to help determine if adult life stage (subimagos versus imagos) and sex (females versus males) had an effect in contaminant concentrations. Results from the PCA with the complete data set for adults provided clear evidence that there was a difference between males and females in the concentrations of some elements (Fig. 30). However, differences between life stages in the analysis were less distinct. The analysis did, however suggest that neither sex nor life stage differences affected spatial trends among sites. As for the nymphs, a spatial gradient of generally highest to lowest concentrations revealed: concentrations of elements were generally highest near the spill site of the ash, and then declined with distance downstream. Interestingly, 
the results for adults from LERM 1.0 in 2009 were clearly indicated that site was unique relative to all other sites. Examination of spatial trends for the individual elements showed that the concentration of Ag in both males and females was approximately four times higher than at any other site (Appendix C, Table C.2; see also the section on "Spatial and temporal trends" below).

PCA results with the entire data set showed that site and sex differences in element concentrations accounted for much of the variation in the results. Since samples with both life stages were available from only a small number of sites, the variation associated with site, sex, and possibly time may have sufficiently dominated the overall variation in the analysis, making it more difficult to detect potentially subtle differences between imagos and subimagos. Therefore, the influence of life stage on element concentrations was reevaluated with PCAs on data subsets. Additionally, even though the initial PCA showed that distinct sex differences were present, large concentration differences among sites and possibly years could likewise obscure more subtle sex-related trends. Thus, potential differences between sexes were also reexamined with PCAs using data subsets. The most extensive data set for adults was from samples collected in 2010, so only samples from that year were included, thus eliminating time as a possible factor affecting the results. Additionally, only those sites having matching pairs (i.e., subgroups of female imagos and subimagos, male imagos and subimagos, male and female subimagos, and male and female imagos) were used in the analyses. Only two sites were available for comparisons of female subimagos and imagos (ERM 2 and CRM 3.5) while seven sites had male subimagos and imagos present (ERM 0.6, ERM 1, ERM 2, TRM 563, TRM 566, TRM 568, and TRM 572). For comparisons between male and female subimagos from six sites were available (ERM 0.6, ERM 1, ERM 2, TRM 563, TRM 568, and TRM 572), but only four sites were available for comparing male and female imagos (ERM 2, ERM 3, CRM 1.5, and CRM 3.5).

Results of the PCAs on the subgroups of adult mayflies showed more clearly that there were distinct differences in the overall patterns in element concentrations between subimagos and imagos for both sexes at the sites examined (Table 7, Fig. 31), and further confirmed the presence of a distinct difference between males and females (Fig. 32). The spatial trends exhibited by each subgroup were similar to the trends apparent from the analysis of the entire data set.

Only the PCA loadings from the analyses of the four subgroups were assessed to help select the elements for more detailed analysis; the results of these analyses are summarized in Table 5. Five of the eight bioaccumulative elements of concern were important in trends found in PCA including $\mathrm{As}, \mathrm{Cu}, \mathrm{Hg}$, $\mathrm{Se}$, and $\mathrm{Zn}$; because $\mathrm{Cr}, \mathrm{Pb}$, and $\mathrm{Ni}$ were not detected in samples from several sites, those elements were excluded from further analysis. Eleven of the constituents of concern contributed strongly to trends observed in adult mayflies as well, and thus, were considered good candidates for further evaluation. 


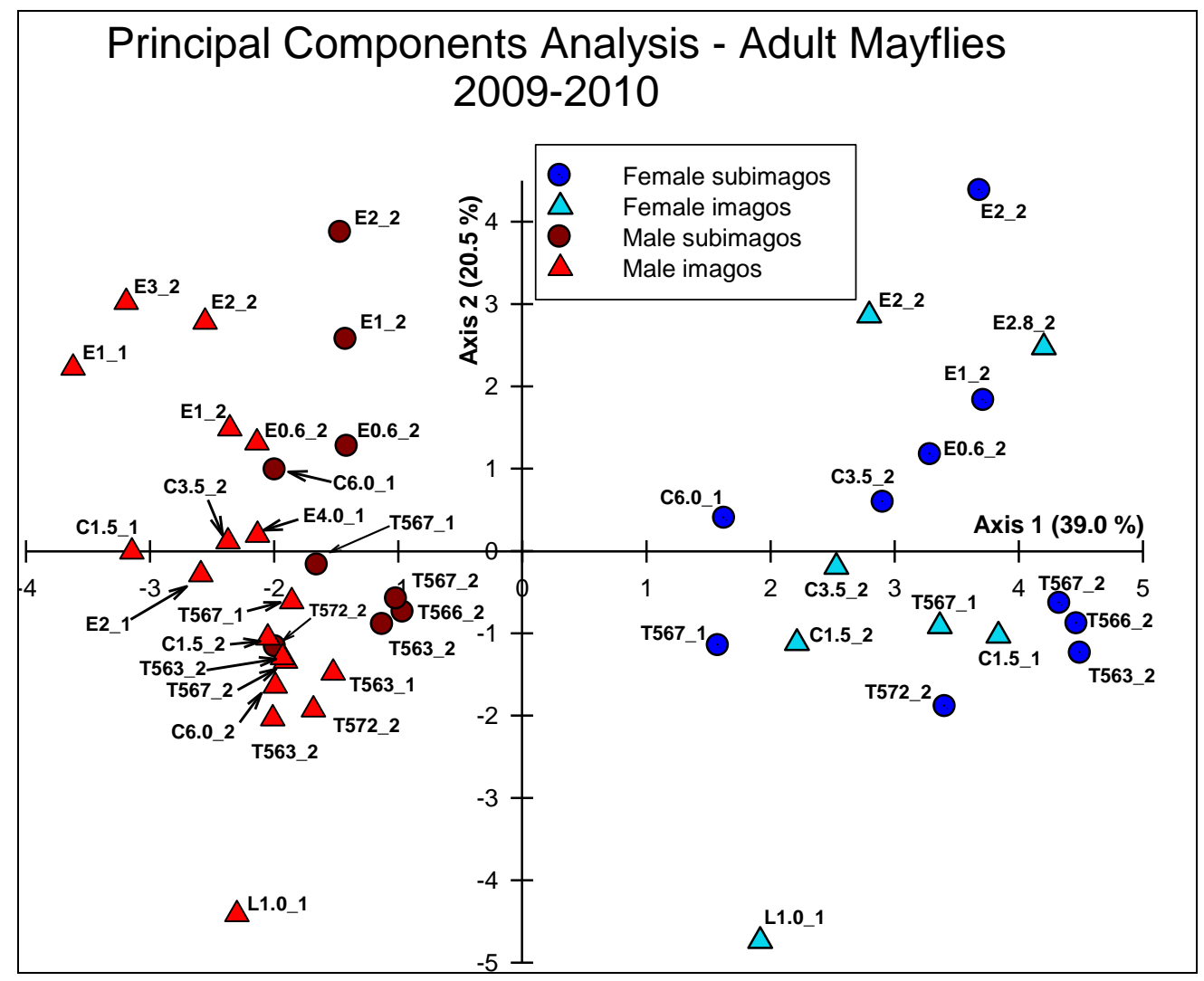

Fig. 30. Principal components analysis plots for adult mayfly bioaccumulation results in 2009 and 2010. Mean values of 18 elements (see Table 5) were used for each site and sample year in the analysis, and each symbol represents an integrated response for the elements. In addition to use of the same label naming convention used in Fig. 2, the "_1" and "_2" after the river mile in each label stands for sample years 2009 and 2010 respectively. 
Table 7. Principal component analysis loadings (i.e., correlation coefficients which range from -1.0

to 1.0) for elements in adult mayflies. Loadings from the first one (Axis 1) or two (Axis 2) axes from

PCAs that included the full suite of detectable elements are shown, and only the loadings that were $\geq 0.7$

(both negative and positive) are included. A “_“ in front of an element indicates a negative loading, otherwise, loadings are positive. All elements identified from the analysis not considered essential macro-elements (i.e., $\mathrm{Ca}, \mathrm{Mg}, \mathrm{K}, \mathrm{Na}$ ) were considered good candidates for additional statistical analyses.

\begin{tabular}{|c|c|c|c|c|c|}
\hline Analysis & Axis & $\begin{array}{c}\text { Percent of } \\
\text { variance explained }\end{array}$ & Loadings $>0.9$ & $\begin{array}{c}\text { Loadings } 0.8- \\
0.9\end{array}$ & $\begin{array}{c}\text { Loadings } 0.7- \\
0.8\end{array}$ \\
\hline $\begin{array}{l}\text { Imagos versus } \\
\text { subimagos - } \\
\text { females }\end{array}$ & $1^{\mathrm{st}}$ & $64.4 \%$ & $\begin{array}{c}\mathrm{As}, \mathrm{Ba},-\mathrm{Cd},- \\
\mathrm{Ca}, \mathrm{Mn},-\mathrm{Hg}, \\
\mathrm{Se},-\mathrm{Ag}, \mathrm{Sr}\end{array}$ & Mo, -V & None \\
\hline $\begin{array}{l}\text { Imagos versus } \\
\text { subimagos - } \\
\text { males }\end{array}$ & $1^{\text {st }}$ & $34.9 \%$ & -As, -Ba, -Se & $\mathrm{Cd}$ & $\mathrm{Co}$ \\
\hline $\begin{array}{l}\text { Imagos versus } \\
\text { subimagos - } \\
\text { males }\end{array}$ & $2^{\text {nd }}$ & $28.4 \%$ & $-\mathrm{Na}$ & $\mathrm{Fe},-\mathrm{Zn}$ & $-\mathrm{Ca}$ \\
\hline $\begin{array}{l}\text { Males versus } \\
\text { females - } \\
\text { subimagos }\end{array}$ & $1^{\text {st }}$ & $49.0 \%$ & $\begin{array}{c}-\mathrm{Cu},-\mathrm{Fe},-\mathrm{Mg},- \\
\mathrm{Sr}, \mathrm{Zn}\end{array}$ & $\mathrm{Mn},-\mathrm{K},-\mathrm{Na}$ & $-\mathrm{Ba}$ \\
\hline $\begin{array}{l}\text { Males versus } \\
\text { females - } \\
\text { subimagos }\end{array}$ & $2^{\text {nd }}$ & $31.9 \%$ & $-\mathrm{Se}$ & $\mathrm{Cd}, \mathrm{Co},-\mathrm{Mo}, \mathrm{Ag}$ & -As \\
\hline $\begin{array}{l}\text { Males versus } \\
\text { females - } \\
\text { imagos }\end{array}$ & $1^{\text {st }}$ & $52.1 \%$ & $\begin{array}{c}-\mathrm{Cu},-\mathrm{Fe}, \mathrm{Mg} \\
\mathrm{Mn},-\mathrm{K}, \mathrm{Zn}\end{array}$ & $\mathrm{Ca}, \mathrm{Mo}$ & $-\mathrm{V}$ \\
\hline $\begin{array}{l}\text { Males versus } \\
\text { females - } \\
\text { imagos }\end{array}$ & $2^{\text {nd }}$ & $30.0 \%$ & $\mathrm{Cd}, \mathrm{Co}$ & -As, -Ba & None \\
\hline
\end{tabular}



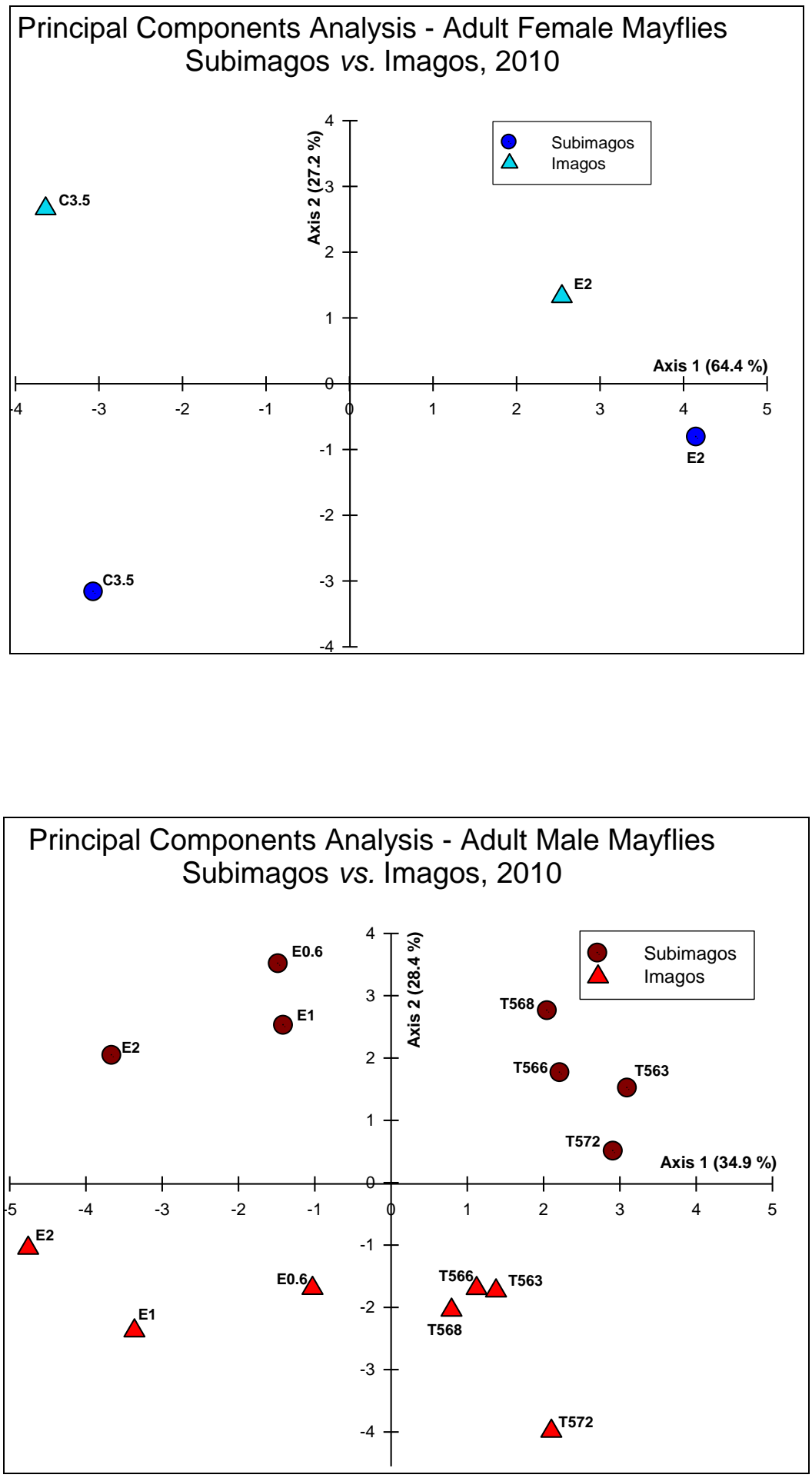

Fig. 31. Principal components analysis plots for comparisons of bioaccumulation results (2010 data only) for the subimago and imago stages of adult mayflies. The analysis was performed separately on females (top graph) and males (bottom graph). Mean values of 18 elements (see Table 5) were used for each site and sample-year in the analysis, and each symbol represents an integrated response for the elements. See Fig. 2 for description of symbol labels and PCA plot. 

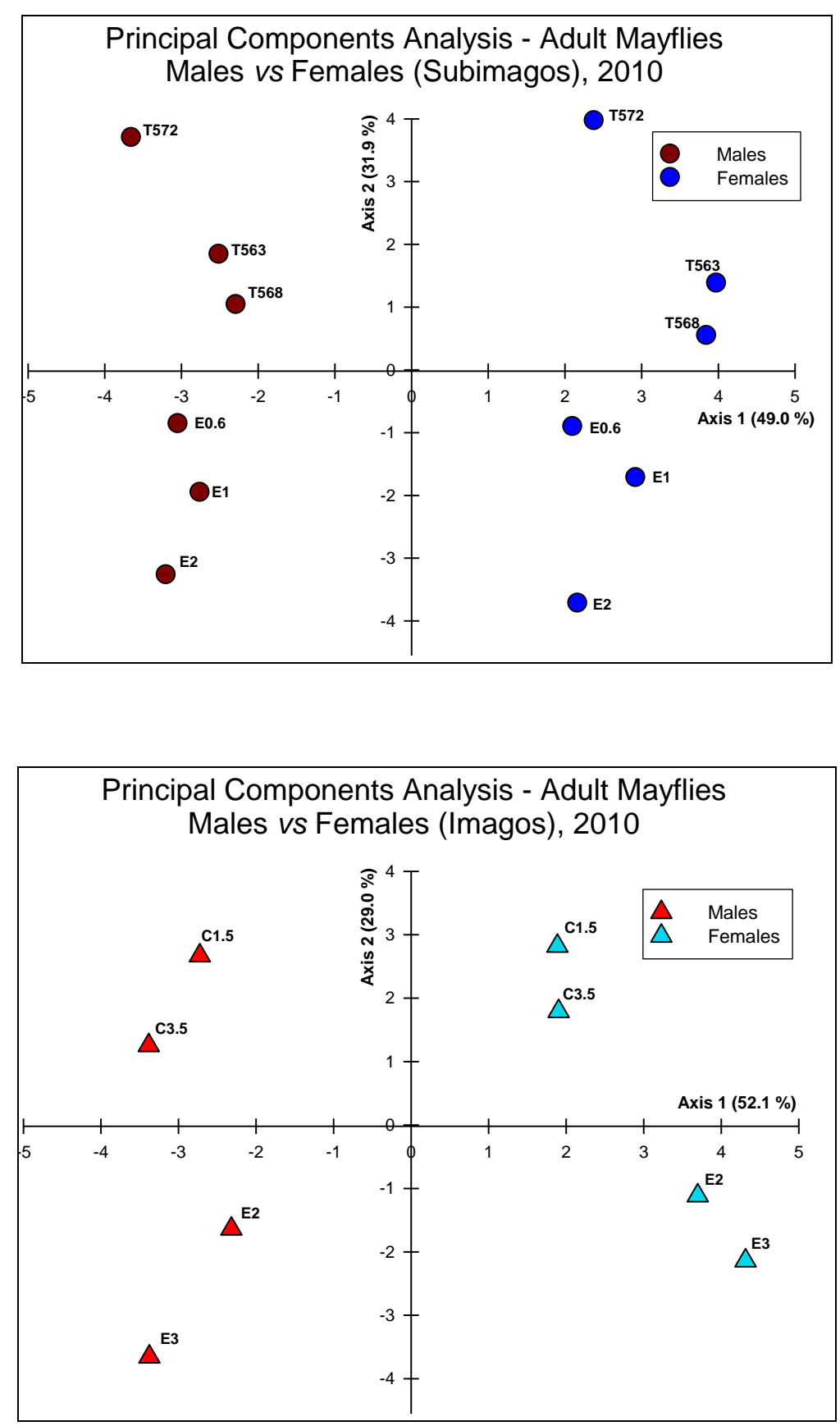

Fig. 32. Principal components analysis plots for comparisons of bioaccumulation results (2010 data only) for female and male adult mayflies. The analysis was performed separately on subimagos (top graph) and imagos (bottom graph). Mean values of 18 elements (see Table 5) were used for each site and sample year in the analysis, and each symbol represents an integrated response for the elements. See Fig. 2 for description of symbol labels and PCA plot. 


\subsubsection{Element-Specific Results}

Based on PCA results and trends evident from plots of mean concentrations, the elements As, Ba, $\mathrm{Cd}, \mathrm{Co}, \mathrm{Cu}, \mathrm{Hg}, \mathrm{Mo}, \mathrm{Se}, \mathrm{Ag}, \mathrm{Sr}, \mathrm{V}$, and $\mathrm{Zn}$ appeared to occur at concentrations in adult mayflies that were either affected by the ash spill, could provide information on source identification, or was of interest because they are considered bioaccumulative constituents of concern. Manganese was also evaluated in the analysis of sex differences, but it was not included in the overall analysis of spatial and temporal trends. Mean concentrations for all elements adult mayfly samples are provided in Appendix C, Tables C.1-C.3; means are presented by adult subgroups. Plots of mean element concentrations evaluated in more detail are presented in Figs. 17, 18, 20, 21, 23-29.

Effect of adult developmental stage and sex -Differences between life stages generally were not as strong as those between sexes, particularly those of the females (Table 8). In females As, Ba, and Mo were higher in subimagos and $\mathrm{Cd}, \mathrm{Co}, \mathrm{Cu}$ and $\mathrm{Ag}$ were higher in imagos, while there appeared to be no differences between stages in the concentrations of $\mathrm{Hg}, \mathrm{Se}, \mathrm{Sr}, \mathrm{V}$, and $\mathrm{Zn}$. For the males, there appeared to be differences between the two adult stages for all elements except $\mathrm{Hg}$ and $\mathrm{V}$. Of the elements compared between male adult stages, $\mathrm{Cd}, \mathrm{Cu}$, and $\mathrm{Ag}$ were higher in the imagos, while $\mathrm{As}, \mathrm{Ba}$, $\mathrm{Co}, \mathrm{Mo}, \mathrm{Sr}$, and $\mathrm{Zn}$ were higher in the subimagos.

As suggested from the results of the PCAs on adult mayflies, several elements showed strong sex differences in concentrations. Of the 13 elements included in the analyses of sex effects, only Co appeared to exhibit no difference between sexes in the subimagos (Fig. 21, Table 8). However, differences did appear to exist in concentrations of the other 12 elements. Higher concentrations of As, $\mathrm{Mn}, \mathrm{Mo}, \mathrm{Se}$, and $\mathrm{Zn}$ were found in the females of both adult life stages, while concentrations of $\mathrm{Ba}, \mathrm{Cd}$, $\mathrm{Cu}, \mathrm{Hg}, \mathrm{Ag}, \mathrm{Sr}$, and $\mathrm{V}$ were found in males of both groups.

Spatial and temporal trends - Having determined that concentrations of elements varied with adult life stage and sex, the overall analysis of spatial and temporal trends was completed on those groups having maximum concentrations. The specific groups used in the analysis of each element are shown in Table 9. As found for the snails and nymphs, site differences were found in concentrations of most elements in adult mayflies (Table 9, Figs. 17, 18, 20, 21, 23-29).

Zinc concentrations differed little among sites, thus fly ash had no discernible effect on $\mathrm{Zn}$ concentrations in adult mayflies (Fig. 29). As found for snails and mayfly nymphs, concentrations of Ag in adult mayflies were highest at LERM 1.0 (Fig. 26). With such a high background concentration at a location upstream of the ash spill, it was not possible to determine if any of the Ag found in mayflies downstream of the spill site had a possible association with fly ash. While some site differences existed in concentrations of $\mathrm{Cu}$, the range in concentrations among sites and years was relatively narrow ( $23-$ $31 \mu \mathrm{g} / \mathrm{g}$ dry weight) (Fig. 21). Like the snails and mayfly nymphs, the Clinch River was clearly the most significant source of $\mathrm{Hg}$ downstream of the Emory River (Fig. 23). The highest concentration of $\mathrm{Hg}$ found in adults was at CRM 6.0, although these concentrations were considerably lower than those found in the nymphs (Fig. 23). Concentrations of $\mathrm{Cd}$ in adult mayflies also were lower than in nymphs, although and the spatial trends exhibited by the adults were similar to those of non-depurated nymphs (Fig. 20); highest concentrations in both of these groups were found at CRM 1.5 and LERM 1.0. 
Table 8. Summary of two-way ANOVA results for analysis of effects on adult life stage (subimago versus imago) and sex (female versus male) on element concentrations. See Table 2 for a summary of statistical design used for each analysis. Only the results for main comparison of interest are included (i.e., effects of adult life and sex). Results for associated P-values are given only for general guidance for evaluating trends (see Materials and Methods).

\begin{tabular}{|c|c|c|c|c|}
\hline $\begin{array}{l}\text { Comparison } \\
\text { group }\end{array}$ & $\begin{array}{c}\text { Comparison } \\
\text { subgroup }\end{array}$ & $\mathrm{P}>0.05$ & $\mathrm{P}<0.05$ to $\mathrm{P}>0.01$ & $\mathrm{P} \leq 0.01$ \\
\hline \multirow{2}{*}{$\begin{array}{l}\text { Subimago } \\
\text { versus imago } 1\end{array}$} & Females & $\mathrm{Hg}, \mathrm{Se}, \mathrm{Sr}, \mathrm{V}, \mathrm{Zn}$ & $\underline{\mathbf{A s}}, \underline{\mathbf{B a}}, \mathrm{Co}, \mathrm{Cu}, \mathrm{Ag}$ & $\mathrm{Cd}, \underline{\text { Mo }}$ \\
\hline & Males & $\mathrm{Hg}, \mathrm{V}$ & $\mathrm{Se}$ & $\underline{\mathbf{A s}}, \underline{\mathbf{B a}}, \mathrm{Cd}, \underline{\mathbf{C o}}, \mathrm{Cu}, \underline{\mathbf{M o}}, \mathrm{Ag}$, \\
\hline \multirow{2}{*}{$\begin{array}{l}\text { Female } \\
\text { versus male }\end{array}$} & Subimago & $\mathrm{Co}$ & & $\begin{array}{c}\underline{\mathbf{A s}}, \mathrm{Ba}, \mathrm{Cd}, \overline{\mathrm{Cu}}, \underline{\overline{\mathbf{M n}}}, \mathrm{Hg}, \underline{\mathbf{M o}}, \\
\underline{\mathbf{S e}}, \mathrm{Ag}, \mathrm{Sr}, \mathrm{V}, \underline{\mathbf{Z n}}\end{array}$ \\
\hline & Imago & & Co & $\begin{array}{c}\underline{\mathbf{A s}}, \mathrm{Ba}, \mathrm{Cd}, \mathrm{Cu}, \underline{\mathbf{M n}}, \overline{\mathrm{Hg}}, \underline{\mathbf{M o}}, \\
\text { Se }, \mathrm{Ag}, \mathrm{Sr}, \mathrm{V}, \underline{\mathbf{Z n}}\end{array}$ \\
\hline
\end{tabular}

${ }^{1}$ Those elements underlined and highlighted in bold were higher in subimagos.

${ }^{2}$ Those elements underlined and highlighted in bold were higher in females. 
Table 9. Summary results for ANOVAs performed on individual elements in adult mayflies.

\begin{tabular}{|c|c|c|c|c|c|}
\hline Element $^{1}$ & Model tested & Model terms & $\mathrm{DF}^{2}$ & F-value & P-value \\
\hline Arsenic $^{3}$ & One-way (site) - 2010 & Site & 6,23 & 71.84 & $<0.001$ \\
\hline Barium $^{4}$ & One-way (site) - 2010 & Site & 5,20 & 31.88 & $<0.001$ \\
\hline \multirow{5}{*}{ Cadmium $^{5}$} & One-way (site) - 2009 & Site & 5,19 & 121.62 & $<0.001$ \\
\hline & One-way (site) - 2010 & Site & 9,35 & 154.98 & $<0.001$ \\
\hline & \multirow{3}{*}{ Two-way (site x year) } & Site & 3,23 & 107.26 & $<0.001$ \\
\hline & & Year & 1,23 & 60.09 & $<0.001$ \\
\hline & & Site $\mathrm{x}$ year & 3,23 & 89.11 & $<0.001$ \\
\hline \multirow{5}{*}{ Copper $^{5}$} & One-way (site) - 2009 & Site & 5,19 & 70.69 & $<0.001$ \\
\hline & One-way (site) - 2010 & Site & 9,35 & 7.12 & $<0.001$ \\
\hline & \multirow{3}{*}{ Two-way (site x year) } & Site & 3,26 & 15.82 & $<0.001$ \\
\hline & & Year & 1,26 & 40.77 & $<0.001$ \\
\hline & & Site $\mathrm{x}$ year & 3,26 & 20.33 & $<0.001$ \\
\hline \multirow{5}{*}{ Mercury $^{5}$} & One-way (site) - 2009 & Site & 4,15 & 159.71 & $<0.001$ \\
\hline & One-way (site) - 2010 & Site & 9,35 & 98.71 & $<0.001$ \\
\hline & \multirow{3}{*}{ Two-way (site x year) } & Site & 2,16 & 27.80 & $<0.001$ \\
\hline & & Year & 1,16 & 4.78 & 0.051 \\
\hline & & Site $\mathrm{x}$ year & 2,16 & 61.01 & $<0.001$ \\
\hline Molybdenum $^{3}$ & One-way (site) - 2010 & Site & 6,23 & 183.91 & $<0.001$ \\
\hline Selenium $^{6}$ & One-way (site) - 2010 & Site & 5,23 & 240.46 & $<0.001$ \\
\hline \multirow{5}{*}{ Silver $^{5}$} & One-way (site) - 2009 & Site & 4,15 & 361.62 & $<0.001$ \\
\hline & One-way (site) - 2010 & Site & 9,35 & 480.06 & $<0.001$ \\
\hline & \multirow{3}{*}{ Two-way (site x year) } & Site & 3,26 & 60.30 & $<0.001$ \\
\hline & & Year & 1,26 & 2.03 & 0.170 \\
\hline & & Site $\mathrm{x}$ year & 3,26 & 153.71 & $<0.001$ \\
\hline Strontium $^{4}$ & One-way (site) - 2010 & Site & 5,20 & 8.72 & $<0.001$ \\
\hline \multirow{5}{*}{ Vanadium $^{5}$} & One-way (site) - 2009 & Site & 5,19 & 19.36 & $<0.001$ \\
\hline & One-way (site) - 2010 & Site & 9,35 & 42.48 & $<0.001$ \\
\hline & \multirow{3}{*}{ Two-way (site x year) } & Site & 3,26 & 8.05 & 0.001 \\
\hline & & Year & 1,26 & 1.14 & 0.298 \\
\hline & & Site $\mathrm{x}$ year & 3,26 & 16.40 & $<0.001$ \\
\hline Zinc $^{6}$ & One-way (site) - 2010 & Site & 5,23 & 0.70 & 0.633 \\
\hline
\end{tabular}

${ }^{\mathrm{I}}$ Mayfly subgroups with the highest concentration for specific element were used in the analysis of that element.

${ }^{2} \mathrm{DF}=$ degrees of freedom.

${ }^{3}$ Analysis based on female subimagos.

${ }^{4}$ Analysis based on male subimagos.

${ }^{5}$ Analysis based on male imagos.

${ }^{6}$ Analysis based on pooled samples of female subimagos and imagos. 
In 2009 there appeared to be no clear spatial trend indicative of an association of $\mathrm{Sr}$ with the ash spill (Fig. 27). However, male imagos exhibited a distinct concentration gradient in 2010, with the highest concentration at ERM 2.8 followed by successively declining concentrations at ERM 2, ERM 1, and ERM 0.6. Concentrations of $\mathrm{Sr}$ at all Clinch River and Tennessee River sites were comparable to those at ERM 1 and ERM 0.6 in 2010.

Not only were spatial trends for As, Se, V, and Ba similar in adult mayflies, they also were similar to those exhibited by non-depurated nymphs (Figs. 17, 18, 25, and 28). Their highest concentrations in 2010 were found at ERM 2.8 or ERM 2, but in 2009, the highest concentrations of all but $\mathrm{Ba}$ were found at ERM1. Concentrations of all but vanadium declined with distance downstream of the Emory River, while concentrations of vanadium at CRM 3.5 and CRM 1.5 were comparable to those at the lower Emory River sites.

There appeared to be no difference between years in the concentrations of $\mathrm{Hg}, \mathrm{Ag}$, or V (Table 9, Figs. 23, 26, 28). With few exceptions concentrations of As, Ba, and Sr generally increased at Emory River sites in 2010, but decreased at sites downstream of the Emory River (Figs. 17, 18, and 27).

Concentrations of $\mathrm{Cd}, \mathrm{Cu}$, and Mo were generally lower at most sites in 2010 (Figs. 20, 21, and 24). Vanadium increased at ERM 2 in 2010, but was considerably lower at ERM 1 and CRM 1.5 in 2010 relative to 2009 (Fig 28). Selenium concentrations generally increased or remained unchanged in 2010 (Fig. 25). 


\section{DISCUSSION}

This section is organized to facilitate identification of those elements that could potentially pose or contribute to undue risk to wildlife receptors that are potential consumers of aquatic invertebrates. Understanding differences among the groups will provide essential information for understanding the transport and fate of contaminants. Identifying the source(s) of those elements that may pose a potential risk to consumers is needed to help provide guidance for future remedial actions at the spill site. Misidentification of source(s) could lead to unnecessary expenditures on remedial actions (incorrectly identifying fly ash as the source) or negative consequences to the environment (incorrectly concluding the source was not related to the fly ash).

\subsection{ASSESSMENT OF GROUP/SPECIES DIFFERENCES IN CONTAMINANT CONCENTRATIONS}

A summary of the invertebrate group that had the highest concentrations of each element is given in Table 10. With few exceptions, the concentrations of most elements were much lower in adult mayflies than in snails and nymphs, and no element was found with higher concentrations in adult mayflies than both the snails and nymphs. Concentrations of $\mathrm{Zn}$ were relatively similar among snails, nymphs and female subimagos, but concentrations of $\mathrm{Zn}$ in male mayflies as much as 2 times lower than those in the nymphs and snails. Differences among groups in Se concentrations varied somewhat by river. Concentrations of Se at Clinch River sites were similar among the three groups of invertebrates, but at the Emory River sites downstream of the ash spill, Se concentrations were higher in mayfly nymphs and adults.

The highest concentrations of the remaining elements were found in either the snails or mayfly nymphs, or in the case of As, Mn, Hg, and Mo, there was little difference between these two groups (Table 10). Most elements differed by a factor of about 1.5 to $5 \mathrm{x}$, but concentrations of $\mathrm{Ag}$ and $\mathrm{Cu}$ in snails were approximately $25 \mathrm{x}$ and up to $10 \mathrm{x}$ higher, respectively, than in mayflies. Other elements having higher concentrations in snails were $\mathrm{Cd}, \mathrm{Co}, \mathrm{Ni}, \mathrm{Sr}$, and $\mathrm{Tl}$, while concentrations of $\mathrm{Al}, \mathrm{Sb}, \mathrm{Ba}, \mathrm{B}$, $\mathrm{Cr}, \mathrm{Fe}, \mathrm{Pb}$, and $\mathrm{V}$ were higher in nymphs.

Distinct sex and adult life stage differences were found in the concentrations of many elements in adult mayflies. In addition to differences in element concentrations, the mean individual weights (dry weights or DW) of the four groups differed as well. For example, in 2010 mean individual weights for adults mayfly subgroups were as follows: female subimagos $=41.19 \mathrm{mg}$ DW/individual; female imagos = $34.18 \mathrm{mg}$ DW/individual; male subimagos $15.63 \mathrm{mg}$ DW/individual; and male imagos $=12.26 \mathrm{mg}$ DW/individual. This would mean that the total contaminant burden received by consumers could vary if feeding strategies/behaviors result in the selective consumption of a particular sex and/or adult life stage. Male mayflies generally merge near sunset and several hours before females, and after emergence, each sex may select a different subhabitat where they will perch until their final molt ( $8-24 \mathrm{hr}$ later) into the final imago stage. Their mating swarms do not begin until after their final molt (i.e., swarms usually occur $24-36 \mathrm{hr}$ after first emerging). When the mating ritual begins (usually around sundown or sunrise), the males fly in large stationary swarms and then females fly through the middle of the swarming males. Females may mate multiple times before usually landing on the surface of the water to deposit their eggs. Most females remain on the water's surface where they die naturally or are consumed. 
As long as they are alive, males will continue to exhibit swarming behavior in late evening and early morning until they die naturally or are consumed. Generally adults live no more than $\sim 48 \mathrm{hr}$. These life history characteristics could have subtle consequences on contaminant exposures to consumers that might live or feed preferentially in specific habitats during a limited period of the day. For example, bats would feed on emerging mayflies only in near and after sunset or sunrise, while most birds would likely feed on mayflies between dawn and sunset. If males began emerging near dusk and females began near sunrise the next day, then bats would initially consume predominantly male subimagos. With molting to the final imago stage taking about 8 to $12 \mathrm{hr}$, birds, in contrast, may initially be exposed to a mixture of the subimagos and imagos of the males and subimagos of females, but then later be exposed to the imagos of both sexes. Likewise, bats would consume predominantly imagos after the first day of emergence. These consumers would most likely feed until satiated, which is likely to be after a certain mass is consumed. Birds feeding throughout the day are likely to feed on all stages, while bats are most likely to feed to male subimagos the first day and male and female imagos the second day. Smaller consumers on the other

hand, such as spiders, will become satiated after consuming much less mass. Thus, the total exposure to a contaminant could depend on the predominant stage or sex present when satiation is achieved.

\subsection{IDENTIFICATION OF ELEMENT SOURCE}

The elements assessed in this study and the sites where the highest mean concentrations were found in each invertebrate subgroup are listed in Table 11. Information on depurated and non-depurated snails and mayfly nymphs was kept separate, while adult mayflies were considered as a single group. The number of elements with maximum concentrations for each site was then counted, and the results are summarized in Table 12; the macro-elements $\mathrm{Ca}, \mathrm{Mg}, \mathrm{P}$, and $\mathrm{Na}$ were excluded from the totals. Some sites were not equally represented in the counts because fewer collections were made (e.g., snails were not collected at CRM 3.5 until 2010, and depurated nymphs and non-depurated snails were not analyzed from all sites). However, the results serve as a useful tool for identifying possible contaminant "hot spots", and thus, information on the potential source(s).

Highest concentrations for most elements were found between ERM 2.5 and CRM 1.5 in all three groups of invertebrates, although the specific sites for many of these elements differed among groups. Overall, maximum concentrations of elements were found most frequently at ERM 1.0 (34.5\%), followed by CRM 1.5 (17.0\%), and ERM 2.5 (15.1\%). The number of elements with maximum concentrations in snails was generally distributed among two (non-depurated) to four (depurated) sites that could have either been affected by fly ash (ERM 2.5, ERM 1.0, CRM 1.5 and ERM 4.0) or an anthropogenic source from the Clinch River (CRM 6.0, CRM 1.5, and ERM 1.0). However, maximum concentrations of Ag were found at ERM 6.0 and LERM 1.0, and the maximum concentration of B in depurated snails was found at LERM 1.0, indicating a potential anthropogenic or geochemical source in the Little Emory River.

Sixty-one percent of the highest element concentrations in mayfly nymphs were found at ERM 1.0, with a much lower frequency of maximum concentrations detected at CRM 1.5 ( 18 \%), ERM 2.5 $(\sim 7 \%)$, and LERM $1.0(\sim 7 \%)$. This suggests a strong link between many of these elements and the fly ash spill in the Emory River, but it also suggests that additional sources of some contaminants are likely present upstream of the spill site. This is clearly the case for $\mathrm{Hg}$, with the source coming from the Clinch River upstream of CRM 6.0, and probably is the primary source of $\mathrm{Hg}$ at ERM 1.0. 
The highest concentrations of most elements in adult mayflies were found adjacent to and just downstream of the ash spill site (ERM 2.5, ERM 1, CRM 1.5). As found for the snails and nymphs, the highest concentrations of Co and Ag were found at LERM 1.0.

\subsubsection{Element-specific discussion}

Aluminum - Aluminum is the most abundant metal on earth and a major constituent of minerals and clays. Iron, $\mathrm{Cr}$, and $\mathrm{V}$ also occur naturally in these materials, and therefore their concentrations are often correlated with those of Al (FOREGS 2011). For this reason, disturbed clays and soils that enter the water column may have a high Al content (Dahlgren and Driscoll 1994). It was not clear from the results that fly ash was a source of $\mathrm{Al}$ to invertebrate tissue concentrations at any site. However, a peak in $\mathrm{Al}$ concentrations occurred in non-depurated snails and mayfly nymphs at ERM 2.5 in 2010. Collection of samples in 2010 occurred while fly ash dredging operations were in progress or soon after dredging ceased. Dredging likely disturbed native clays in the river channel, causing suspension of lighter particles that could have been carried downstream by river current and deposited on surface sediments. Because snails and Hexagenia nymphs gather their food from the surface of the substrate, these fresh deposits of clay could have been consumed incidentally while feeding, and thus, contributed to higher concentrations of $\mathrm{Al}$ in the invertebrates. If disturbed clays were a significant source of $\mathrm{Al}$ in 2010, then concentrations should decline as the clay particles are flushed downriver during high discharge events or covered by natural sedimentation processes.

Antimony - Antimony concentrations were typically low in all groups, and it was not detected in a large proportion of snail and adult mayfly samples. However, spatial trends in concentrations in both depurated and non-depurated nymphs suggest that the fly ash may have been the primary cause of the higher $\mathrm{Sb}$ concentrations in mayfly nymphs downstream of the spill site.

Arsenic - Trends in As for all three groups of invertebrates downstream of the spill site showed strong evidence of an association with fly ash in the Emory and Clinch Rivers downstream of the spill site. However, concentrations of As in both depurated and non-depurated snails from CRM 6.0 were higher than those from all Emory River sites. In an assessment of contaminants in invertebrates and fish in water bodies located on and downstream of the Department of Energy's Oak Ridge Reservation, one of the highest concentrations of As found $(\sim 8.2 \mu \mathrm{g} / \mathrm{g}$ dry mass converted from wet mass assuming $80 \%$ moisture content) was in snails (P. canaliculatum) from CRM 20 (Mathews et al. 2011). Thus, anthropogenic inputs of As into the Clinch River upstream of CRM 6.0 probably also contribute to As burdens further downstream, including possibly ERM 1.0 where water from the Clinch River often flows as result of the operations from Melton Hill Dam, Fort Loudon Dam, and Watts Bar Dam.

Barium - Spatial trends in Ba concentrations appear to suggest that fly ash is a possible source of $\mathrm{Ba}$ in nymphs and adult mayflies, but it's less clear if the ash is contributing to burdens in snails.

Boron - Spatial trends in B in nymphs suggest that the fly ash may be contributing to the higher concentrations found downstream of the spill. Results for snails and adult mayflies on the other hand, are more ambiguous and showed no clear association with ash. Other potential sources of B in snails may be anthropogenic sources of unknown origin or from the upper Emory River watershed, as well as, increased clay deposition associated with dredging activities in 2010. 
Cadmium - While there was some indication that $\mathrm{Cd}$ concentrations may have been elevated at some locations in the Clinch River, this study produced no clear evidence that fly ash was contributing significantly to the $\mathrm{Cd}$ burdens in the invertebrate groups evaluated. Even though it cannot be definitively concluded that there has been no increase in exposures to $\mathrm{Cd}$ since the spill, this study suggests that any contributions to $\mathrm{Cd}$ burdens have been too low to produce increases above background that can be reliably be detected.

Chromium - Spatial trends for $\mathrm{Cr}$ in nymphs suggested that fly ash has likely contributed to higher body burden. Results for snails were more ambiguous, although higher concentrations appeared to be present at ERM 1.0 and locations further downstream that could be associated with the ash or an unidentified source to the Clinch River upstream of CRM 6.0. Concentrations of $\mathrm{Cr}$ in adult mayflies showed no clear association with fly ash.

Cobalt - Results for nymphs suggests that the fly ash has likely contributed to an increase in Co concentrations downstream of the spill site, but relatively high concentrations in nymphs from LERM 1.0 suggests the possibility of other sources as well. Maximum concentrations of Co in adult mayflies at LERM 1.0 support this supposition. As with several of the other elements, results for snails suggest that the ash may be contributing to increased concentrations of Co, but similar concentrations at ERM 1.0 and ERM 6.0 in 2010 suggest that a source exists in Emory River upstream of the spill site.

Copper - Copper is an essential trace element that serves a functional role in respiration in many species of invertebrates (Rainbow 2002). Concentrations of $\mathrm{Cu}$ were higher in the depurated than nondepurated snails and mayfly nymphs, and concentrations in depurated mayfly nymphs and adult mayflies were relatively similar. This suggests that any potential increases in $\mathrm{Cu}$ to the environment associated with the fly ash have probably not been significant enough to exceed physiological requirements of the invertebrates included in this study.

Iron - With relatively high concentrations of $\mathrm{Fe}$ at most reference sites, it was not clear if fly ash had contributed to higher Fe body burdens in any group of invertebrates. However, there appeared to be a spike in the concentrations of Fe in non-depurated snails and nymphs at ERM 2.5 in 2010, and as hypothesized for $\mathrm{Al}$, this may reflect a temporary increase in the consumption of clay particles originating from native channel clays that were disturbed in the river channel during dredging activities in the Emory River. There also was some indication that higher background concentrations in the Clinch River drainage may have contributed to higher concentrations of Fe at all sites in the Clinch River and possibly the lower Emory River as well.

Lead - With higher concentrations of Pb in nymphs at ERM 2.5 and ERM 1.0, there was some evidence that the ash spill may have been a contributing factor. However, concentrations of $\mathrm{Pb}$ in nondepurated nymphs at all sites in the Clinch River were similar to those found at ERM 1.0 and ERM 2.5. Thus, it unclear if the higher concentrations of $\mathrm{Pb}$ in the Emory River were associated with the fly ash, an anthropogenic source in the Clinch River, or even possibly naturally higher concentrations in the Clinch River upstream of the Emory River.

Manganese - Trends in Mn in all three groups of invertebrates appeared to primarily be associated with natural geochemical factors in each watershed. 
Mercury - Results for $\mathrm{Hg}$ were perhaps some of the most unambiguous, showing that the main source of this metal is from inputs to the Clinch River upstream of CRM 6.0. There was no clear evidence that fly ash has contributed to increased concentrations of $\mathrm{Hg}$ downstream of the spill site.

Molybdenum - Results for nymphs and adult mayflies provided strong evidence that fly ash was likely contributing to higher Mo concentrations downstream of the spill site. While fly ash appeared to be the significant source of higher Mo concentrations in mayfly nymphs, results appeared to suggest that there also may be a source to the Clinch River. The results for snails were more ambiguous, although they also seemed to suggest that there was a potential source of Mo to the Clinch River.

Nickel - Nickel, like Al, Sb, and Pb, showed little bioaccumulation in adult mayflies. Results for the nymphs, on the other hand, suggested that the fly ash most likely was a source of higher concentrations of this metal downstream of the spill site. As was the case for several other elements, because there were similar concentrations between some sites downstream of the spill with one or more reference site, the results for the snails were sufficiently ambiguous that no clear association could be established with fly ash.

Selenium - Results for Se in all three groups of invertebrates appeared to provide the strongest association with fly ash. Concentrations of Se at ERM 1.0 in both depurated and non-depurated nymphs exceeded EPA's proposed whole body fish criterion of $7.9 \mu \mathrm{g} / \mathrm{g}$ dry weight, while the concentration of Se in depurated nymphs from CRM 3.5 were right at the proposed limit. Similarly, concentrations of Se in female mayflies exceeded the EPA proposed criterion at ERM2 and ERM 0.6.

Silver - There appeared to be no link between fly ash and elevated concentrations in Ag. Highest concentrations of Ag in all three groups were found at LERM 1.0.

Strontium - Fly ash appeared to be a likely source of higher Sr concentrations in all three groups of invertebrates. However, there also appeared to be a possible source of $\mathrm{Sr}$ to snails from the Clinch River that also may have affected snails at ERM 1.0. Results for the nymph and adult mayflies suggest that higher concentrations of $\mathrm{Sr}$ at some sites downstream of the ash spill also could be associated with anthropogenic inputs into the Clinch River.

Thallium - Higher concentrations of $\mathrm{Tl}$ in all three groups of invertebrates appeared to be associated with fly ash, although results for snails suggest a possible source to the Clinch River as well.

Vanadium - Like As, Se, and Tl, spatial trends in V concentrations provided some of the strongest evidence of an association with the fly ash spill. Additionally, there was a spike in concentration of V in non-depurated snails at ERM 2.5 in 2010. As indicated in the discussion on Al, V concentrations are often correlated with those of $\mathrm{Al}$ and $\mathrm{Fe}$. Thus, this gives additional evidence for a possible association between increases in the concentrations of some element and the disturbance of clays during fly ash dredging operations. The effects of dredging on concentrations of elements such as $\mathrm{V}$ should be short lived.

Zinc - Zinc showed little difference among sites except for higher concentrations in snails at ERM 2.5 and ERM 4.0. Differences in snails and nymphs among other sites appeared to be related more too a natural factors, such as geochemical conditions in each watershed. Furthermore, $\mathrm{Zn}$ is an essential trace element in many invertebrate species that is a key component in many metabolic enzymes (Rainbow 
2002). Therefore, these results suggest the possibility of some $\mathrm{Zn}$ enrichment immediately downstream of the spill site, but tissue concentrations at most sites probably reflect natural geologic sources, concentrations within the normal physiological range, and/or detoxified metal in tissues. 
Table 10. Summary of invertebrate groups with the maximum concentration for each element.

\begin{tabular}{|c|c|c|c|c|c|c|}
\hline \multirow{2}{*}{ Element } & \multicolumn{3}{|c|}{ Invertebrate group $^{1}$} & \multirow{2}{*}{$\begin{array}{c}\text { Magnitude of difference } \\
\text { between lowest and highest } \\
\text { mean concentrations }\end{array}$} & \multirow{2}{*}{$\begin{array}{c}\text { Magnitude of difference between } \\
\text { non-depurated nymphs and adult } \\
\text { mayflies }\end{array}$} & \multirow{2}{*}{$\begin{array}{l}\text { Magnitude of difference between } \\
\text { depurated nymphs and adult mayflies }\end{array}$} \\
\hline & Snails & Nymphs & Adults & & & \\
\hline Aluminum & & $\mathrm{X}$ & - & $\sim 3 \mathrm{x}-9 \mathrm{x}$ & - & - \\
\hline Antimony & & $\mathrm{X}$ & & insufficient data & - & - \\
\hline Arsenic & $\mathrm{X}$ & $\mathrm{X}$ & & $\mathrm{ERMs}=\mathrm{N}^{3} ; \mathrm{CRMs}=\mathrm{S}^{3}$ & $15-150 x$ & $15-100 x$ \\
\hline Barium & & $X$ & & $\sim 2 \mathrm{x}$ & $40-190 x$ & $10-45 x$ \\
\hline Boron & & $\mathrm{X}$ & - & $\begin{array}{l}\text { ERMs = site dependent; } \\
\text { CRMs }=\text { Ns } \sim 3 \mathrm{x}\end{array}$ & - & - \\
\hline Cadmium & $\mathrm{X}$ & & & $\sim 2 \mathrm{x}$ & $2-7 x$ & $2-4 x$ \\
\hline Chromium & & $\mathrm{X}$ & - & $\sim 2-3 x$ & - & - \\
\hline Cobalt & $\mathrm{X}$ & & - & $\sim 1.5-2 \mathrm{x}$ & - & - \\
\hline Copper & $\mathrm{X}$ & & & $6 x-10 x$ & $\sim 1.2-1.7 \mathrm{x}$ greater in adults & $\sim 1.3-3 \mathrm{x}$ \\
\hline Iron & & $\mathrm{X}$ & & $\sim 3.5-5 x$ & $\sim 50-80 \mathrm{x}$ & $\sim 7-15 x$ \\
\hline Lead & & $\mathrm{X}$ & - & $\sim 1.5-5 \mathrm{x}$ & - & - \\
\hline Manganese & $\mathrm{X}$ & $\mathrm{X}$ & & $\sim 1.5-3 \mathrm{x}$ & $>100 x$ & $\sim 35-60 \mathrm{x}$ \\
\hline Mercury & $\mathrm{X}$ & $\mathrm{X}$ & & ERMs $\sim$ same; CRMs $=1.5-3 \mathrm{X}$ & $\sim 1.2-10 \mathrm{x}$ & $\sim 1.2-2 \mathrm{x}$ \\
\hline Molybdenum & $X$ & $X$ & & $\mathrm{ERMs} \approx$ to $4 \mathrm{x} ; \mathrm{CRMs} \approx$ to $2 \mathrm{x}$ & $1.5-6 \mathrm{x}$ & $\sim 2.5-7 \mathrm{x}$ \\
\hline Nickel & $X$ & & - & $\sim 1.5-5 \mathrm{x}$ & - & - \\
\hline Selenium & $\mathrm{X}$ & $X$ & $\mathrm{X}$ & site dependent & Groups approximately equal & Groups approximately equal \\
\hline Silver & $\mathrm{X}$ & & & $\sim 25 \mathrm{x}$ & $\sim 3-4 \mathrm{x}$ & $\sim 3-4 \mathrm{x}$ \\
\hline Strontium & $\mathrm{X}$ & & & $\sim 1.5-5 \mathrm{x}$ & $\sim 20-50 x$ & $7-24 x$ \\
\hline Thallium & $\mathrm{X}$ & & & $\approx$ to $2 x$ & - & - \\
\hline Vanadium & & $\mathrm{X}$ & & $\sim 3-5 \mathrm{x}$ & $\sim 75-150 \mathrm{x}$ & $\sim 6-17 x$ \\
\hline Zinc & $\mathrm{X}$ & $\mathrm{X}$ & $\mathrm{X}$ & $\begin{array}{l}\approx \text { equal with female } \\
\text { subimagos; male } \\
\text { concentrations lower }\end{array}$ & $\sim 1.1-2.5 \mathrm{x}$ & Sex dependent $=<0-2 \mathrm{x}$ \\
\hline
\end{tabular}

${ }^{\mathrm{T}}$ Elements with multiple groups marked indicate little to no difference in concentrations.

${ }^{2}$ Unless noted otherwise, concentrations were higher in nymphs.

${ }^{3,} \mathrm{~N} "=$ nymph; "S" = snail 
Table 11. Sites and invertebrate groups where maximum mean concentrations of elements were found in 2009 and 2010.

\begin{tabular}{|c|c|c|c|c|c|}
\hline \multirow{2}{*}{ Element } & \multicolumn{2}{|c|}{ Snails } & \multicolumn{2}{|c|}{ Mayfly nymphs } & \multirow{2}{*}{ Adult mayflies } \\
\hline & Non-depurated & Depurated & Non-depurated & Depurated & \\
\hline Aluminum & ERM2.5 & ERM4.0 & TRM566.3 & ERM1.0 & ERM4.5 \\
\hline Antimony & ERM6.0 & ERM1.0 & ERM1.0 & ERM1.0 & - \\
\hline Arsenic & CRM1.5 & CRM6.0 & ERM1.0 & ERM1.0 & ERM2 \\
\hline Barium & ERM2.5 & ERM4.0 & ERM1.0 & ERM1.0 & ERM2.8 \\
\hline Beryllium & ERM2.5 & ERM2.5 & ERM1.0 & ERM1.0 & - \\
\hline Boron & ERM2.5 & LERM1.0 & ERM1.0 & ERM1.0 & ERM1 \\
\hline Cadmium & CRM1.5 & CRM1.5 & LERM1.0 & CRM1.5 & CRM1.5 \\
\hline Calcium & CRM1.5 & CRM6.0 & CRM6.0 & ERM1.0 & TRM572 \\
\hline Chromium & ERM2.5 & CRM1.5 & ERM1.0 & ERM1.0 & CRM6 \\
\hline Cobalt & ERM1.0 & ERM1.0 & ERM2.5 & ERM1.0 & LERM1.0 \\
\hline Copper & CRM3.5 & CRM6.0 & CRM1.5 & CRM1.5 & ERM1 \\
\hline Iron & ERM2.5 & ERM4.0 & ERM2.5 & ERM1.0 & ERM4.5 \\
\hline Lead & ERM6.0 & CRM1.5 & TRM572.5 & ERM1.0 & - \\
\hline Magnesium & CRM1.5 & CRM6.0 & CRM6.0 & CRM6.0 & ERM2.8 \\
\hline Manganese & CRM1.5 & CRM1.5 & TRM560.8 & CRM1.5 & ERM4.5 \\
\hline Mercury & CRM6.0 & CRM6.0 & CRM6.0 & CRM6.0 & TRM567 \\
\hline Molybdenum & CRM3.5 & CRM6.0 & ERM1.0 & ERM1.0 & ERM2 \\
\hline Nickel & CRM1.5 & ERM6.0 & ERM2.5 & ERM1.0 & - \\
\hline Potassium & ERM2.5 & ERM4.0 & ERM2.5 & ERM4.0 & ERM1 \\
\hline Selenium & CRM1.5 & CRM1.5 & ERM1.0 & ERM1.0 & ERM2 \\
\hline Silver & ERM6.0 & LERM1.0 & LERM1.0 & ERM6.0 & LERM1.0 \\
\hline Sodium & CRM1.5 & LERM1.0 & ERM2.5 & ERM2.5 & TRM572 \\
\hline Strontium & CRM1.5 & CRM6.0 & ERM1.0 & ERM1.0 & ERM2.8 \\
\hline Thallium & ERM1.0 & ERM1.0 & ERM1.0 & ERM1.0 & ERM1 \\
\hline Vanadium & ERM2.5 & CRM3.5 & ERM1.0 & ERM1.0 & CRM1.5 \\
\hline Zinc & CRM1.5 & ERM1.0 & TRM572.5 & LERM1.0 & ERM2.8 \\
\hline
\end{tabular}


Table 12. Site frequencies for maximum concentrations for each invertebrate group in 2009 and 2010. Macro-elements (calcium, magnesium, potassium, and sodium) were excluded from counts. Numbers for each group represents the number of times maximum mean element concentrations were found at a site.

\begin{tabular}{|c|c|c|c|c|c|c|c|}
\hline \multirow{2}{*}{ Site } & \multicolumn{2}{|c|}{$\begin{array}{l}\text { Snails } \\
\end{array}$} & \multicolumn{2}{|c|}{ Mayfly nymphs } & \multirow{2}{*}{$\begin{array}{l}\text { Mayfly } \\
\text { adults }^{1}\end{array}$} & \multirow{2}{*}{$\begin{array}{l}\text { Site } \\
\text { totals }\end{array}$} & \multirow{2}{*}{$\%$ of tota } \\
\hline & Non-depurated & Depurated & Non-depurated & Depurated & & & \\
\hline ERM1.0 & 2 & 4 & 11 & 16 & 4 & 37 & 34.9 \\
\hline ERM2.5 & 7 & 1 & 3 & 0 & 5 & 16 & 15.1 \\
\hline ERM4.0 & 0 & 3 & 0 & 0 & 3 & 6 & 5.7 \\
\hline ERM6.0 & 3 & 1 & 0 & 1 & - & 5 & 4.7 \\
\hline CRM1.5 & 7 & 5 & 1 & 3 & 2 & 18 & 17.0 \\
\hline CRM3.5 & 2 & 1 & 0 & 0 & 0 & 3 & 2.8 \\
\hline CRM6.0 & 1 & 5 & 1 & 1 & 1 & 9 & 8.5 \\
\hline LERM1.0 & 0 & 2 & 2 & 1 & 2 & 7 & 6.6 \\
\hline TRM560.8 & 0 & 0 & 1 & 0 & - & 1 & 0.9 \\
\hline TRM566.3 & 0 & 0 & 1 & 0 & 1 & 2 & 1.9 \\
\hline TRM571.9 & 0 & 0 & 2 & 0 & 0 & 2 & 1.9 \\
\hline Group totals & 22 & 22 & 22 & 22 & 18 & 106 & 100.0 \\
\hline
\end{tabular}

Results from ERM 2.8 and ERM 2 in Table 11 were grouped into "ERM 2.5" for this analysis. 
[THIS PAGE LEFT BLANK INTENTIONALLY] 


\section{INTEGRATION AND CONCLUSIONS}

Based on spatial and temporal trends identified from invertebrate bioaccumulation results in 2009 and 2010, summary information given in Tables 11 and 12, and element-specific details presented in the previous section, a matrix summarizing potential sources of elements is given in Table 13. Based on this summary, the following conclusions are offered:

\section{General conclusions and effects of depuration, sex and adult life stage}

- Copper was the only element that clearly had higher concentrations in depurated snails and mayfly nymphs then in non-depurated specimens. This may reflect a physiological importance for $\mathrm{Cu}$ and not any bioaccumulation concern.

- $\quad$ Aluminum and Fe generally showed the largest decreases in snails and nymphs that were depurated, suggesting a high association of unavailable metal with undigested food particles.

- Elements showing little or no difference between depurated and non-depurated snails included $\underline{\mathrm{As}}, \underline{\mathrm{Cd}}, \underline{\mathrm{Co}}, \underline{\mathrm{Hg}}, \underline{\mathrm{Mo}}, \underline{\mathrm{Ni}}, \underline{\mathrm{Se}}$, and $\underline{\mathrm{Ag}}$.

- $\quad$ Strontium concentrations were higher in depurated than non-depurated snails at some locations (CRM sites and ERM 6.0) but lower at other locations (ERMs 1.0 and 2.5).

- Concentrations of elements not already mentioned were lower in depurated than nondepurated snails.

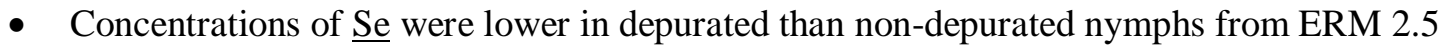
and ERM 1.0, but higher in the depurated nymphs from CRM 1.5 and CRM 3.5.

- Except for $\underline{\mathrm{Cu}}$ and $\underline{\mathrm{Se}}$, concentrations of all elements were lower in depurated mayfly nymphs.

- Concentrations of many elements were found to be different between adult male and female mayflies.

- Concentrations of $\underline{\mathrm{As}}, \underline{\mathrm{Mn}}, \underline{\mathrm{Mo}}, \underline{\mathrm{Se}}$, and $\underline{\mathrm{Zn}}$ were higher in female than male adult mayflies.

- Concentrations of $\underline{\mathrm{Ba}}, \underline{\mathrm{Cd}}, \underline{\mathrm{Cu}}, \underline{\mathrm{Hg}}, \underline{\mathrm{Ag}}, \underline{\mathrm{Sr}}$, and $\underline{\mathrm{V}}$ were higher in male than female adult mayflies.

- Concentrations of $\underline{\text { Co }}$ were higher in male than female imagos, but there was no such difference in the subimagos.

- In addition to sex differences in concentrations of many elements, differences were also found between adult life stages (within sex) for several elements.

- Concentration differences between the subimagos and imagos of females were generally not as great as those for males.

- Concentrations of $\underline{\mathrm{As}}, \underline{\mathrm{Ba}}$, and $\underline{\mathrm{Mo}}$ were higher in the subimagos of females than the imagos, while $\underline{\mathrm{Co}}, \underline{\mathrm{Cu}}, \underline{\mathrm{Ag}}$, and $\underline{\mathrm{Cd}}$ concentrations were higher in the imagos. There were no apparent adult life stage differences in the females for $\underline{\mathrm{Hg}}, \underline{\mathrm{Se}}, \underline{\mathrm{Sr}}, \underline{\mathrm{V}}$, or $\underline{\mathrm{Zn}}$.

- Only the elements $\underline{\mathrm{Hg}}$ and $\underline{\mathrm{V}}$ showed no differences in concentrations between the adult life stages of the males. 
- $\quad \underline{\text { Arsenic }}, \underline{\mathrm{Ba}}, \underline{\mathrm{Co}}, \underline{\mathrm{Mo}}, \underline{\mathrm{Sr}}$, and $\underline{\mathrm{Zn}}$ were higher in the subimagos of the males, while $\underline{\mathrm{Se}}$, $\underline{\mathrm{Cd}}, \underline{\mathrm{Cu}}$, and $\mathrm{Ag}$ were higher in the imagos.

\section{Source and concentration trends}

- The highest concentrations of most elements for all groups of invertebrates occurred downstream of the spill site.

- The highest concentrations of most elements in snails were generally found at ERM 2.5 and CRM 1.5, followed by ERM 1.0.

- The highest concentrations of several elements in depurated snails, including $\underline{\mathrm{As}}, \underline{\mathrm{Hg}}, \underline{\mathrm{Mo}}$, and $\underline{\mathrm{Sr}}$ were found at CRM 6.0, a trend that was not present in non-depurated snails.

- The highest concentrations of most elements in depurated and non-depurated mayfly nymphs were found at ERM 1.0.

- The highest concentrations of many elements (50\%) in adult mayflies were found at ERM 2.5 and ERM 1.0.

- The only element showing an apparent association with only fly ash across all three groups of organisms was $\underline{\mathrm{Se}}$. Concentrations of $\underline{\mathrm{Sb}}$ were often below analytical detection in snails and adult mayflies, but in nymphs, this element appeared to also be associated with fly ash.

- $\quad \underline{\text { Arsenic, }} \underline{\mathrm{Ba}}, \underline{\mathrm{Tl}}$, and $\underline{\mathrm{V}}$ appeared to be primarily associated with fly ash, but results for snails indicated that there was a possible source of $\underline{\mathrm{As}}, \underline{\mathrm{Ba}}$, and $\underline{\mathrm{Tl}}$ coming from the Clinch River upstream of CRM 6.0.

- Fly ash appeared to be one of the main sources of Mo in invertebrates, but results for snails and mayfly nymphs suggest that there may be an additional source in the Clinch River upstream of CRM 6.0.

- Fly ash appeared to be a source of $\underline{\mathrm{Sr}}$ in all three groups of invertebrates, but there appeared to be an additional source in the Clinch River upstream of CRM 6.0. Results for snails showed the greatest association with a source from the Clinch River.

- The elements $\underline{\mathrm{B}}, \underline{\mathrm{Cr}}, \underline{\mathrm{Co}}$, and $\underline{\mathrm{Ni}}$ appeared to have a possible association between the fly ash and elevated concentrations in mayfly nymphs. However, there also appeared to be additional sources potentially contributing to the body burdens of these elements in snails and nymphs, and in some cases, the adult mayflies. There was some indication that some of the $\underline{B}$ may have come from an anthropogenic source in the Emory River upstream of the spill site, an unidentified source of unknown origin, and/or natural geochemical sources.

- The primary source of Ag appeared to be the Little Emory River, although there some indication of a source upstream of ERM 6.0.

- The primary source of $\underline{\mathrm{Hg}}$ was clearly the Clinch River upstream of CRM 6.0.

- The primary source of $\underline{\mathrm{Cd}}$ appears to either be the Clinch River upstream of CRM 6.0 or the upper Emory River drainage.

- While there is some evidence that some $\underline{\mathrm{Cu}}$ and $\underline{\mathrm{Pb}}$ from the fly ash may be accumulating in mayfly nymphs, there appear to be other possible anthropogenic sources from the Clinch River or upper Emory River, possible natural geological deposits, or in the case of $\mathrm{Cu}$, natural concentrations of this essential trace element. 
- While fly ash cannot be total eliminated as a possible source of burdens of $\underline{\mathrm{Al}}, \underline{\mathrm{Fe}}, \underline{\mathrm{Mn}}$, and $\underline{\mathrm{Zn}}$ in the invertebrates, these elements appear to primarily reflect natural background conditions or potentially even natural physiological needs.

- "Spikes" in the concentrations of $\underline{\mathrm{Al}}$ and $\underline{\mathrm{Fe}}$ in 2010 in non-depurated nymphs and snails may be associated with an increase in deposits of native clays that was were most likely disturbed during fly ash dredging operations in the Emory River between the 2009 and 2010 sampling seasons. Boron also showed a similar spike in 2010 and thus, may also reflect an association with fresh clay deposits.

- Vanadium also showed a "spike" in 2010. This element is often associated with Fe and Al (FOREGS 2011), and as such, this spike also may have been associated with fresh clay deposits following disturbance of clays during ash-dredging operations. 
Table 13. Summary matrix of potential sources of elements found to be elevated or potentially elevated in aquatic invertebrates. ${ }^{1}$

\begin{tabular}{|c|c|c|c|c|c|c|c|}
\hline Element $^{2}$ & $\begin{array}{c}\text { Target } \\
\text { invertebrate }^{3}\end{array}$ & Fly ash & $\begin{array}{l}\text { Anthropogenic } \\
\text { source/Clinch } \\
\text { River }\end{array}$ & $\begin{array}{l}\text { Response to } \\
2010 \text { channel } \\
\text { dredging }\end{array}$ & $\begin{array}{c}\text { Natural } \\
\text { background / } \\
\text { geochemical }\end{array}$ & $\begin{array}{l}\text { Anthropogenic } \\
\text { source/Little } \\
\text { Emory River }\end{array}$ & $\begin{array}{l}\text { Unidentified } \\
\text { anthropogenic } \\
\text { sources }\end{array}$ \\
\hline \multirow{3}{*}{ Aluminum } & Snails & & & + & ++ & & \\
\hline & Nymphs & $+1-$ & & + & ++ & & \\
\hline & Adults** & & & & & & \\
\hline \multirow{3}{*}{ Antimony } & Snails** & & & & & & \\
\hline & Nymphs & ++ & & & & & \\
\hline & Adults** & & & & & & \\
\hline \multirow{3}{*}{ Arsenic } & Snails & + & + & & & & \\
\hline & Nymphs & ++ & & & & & \\
\hline & Adults & ++ & & & & & \\
\hline \multirow{3}{*}{ Barium } & Snails & $+1-$ & $+1-$ & & & & \\
\hline & Nymphs & ++ & & & & & \\
\hline & Adults & + & & & & $+1-$ & \\
\hline \multirow{3}{*}{ Boron } & Snails & $+1-$ & & $+1-$ & $+1-$ & $+1-$ & $+1-$ \\
\hline & Nymphs & ++ & $+1-$ & & $+1-$ & & \\
\hline & Adults* & $+1-$ & & & & & \\
\hline \multirow{3}{*}{ Cadmium } & Snails & & $+1-$ & & & & $+1-$ \\
\hline & Nymphs & & $+1-$ & & & $+1-$ & $+1-$ \\
\hline & Adults & & $+1-$ & & & & $+1-$ \\
\hline \multirow{3}{*}{ Chromium } & Snails & $+1-$ & $+1-$ & & & & \\
\hline & Nymphs & + & $+1-$ & & & & \\
\hline & Adults* & & $+1-$ & & & & \\
\hline \multirow{3}{*}{ Cobalt } & Snails & $+1-$ & & & & $+1-$ & \\
\hline & Nymphs & + & $+1-$ & & & $+1-$ & \\
\hline & Adults* & & & & & $+1-$ & \\
\hline \multirow{3}{*}{ Copper } & Snails & & $+1-$ & & $+1-$ & & \\
\hline & Nymphs & + & $+1-$ & & $+1-$ & & $+1-$ \\
\hline & Adults & & $+1-$ & & $+1-$ & & $+1-$ \\
\hline \multirow{3}{*}{ Iron } & Snails & & & + & + & & \\
\hline & Nymphs & $+1-$ & + & + & + & + & \\
\hline & Adults* & $+1-$ & & & + & $+1-$ & \\
\hline \multirow{3}{*}{ Lead } & Snails & & & & $+1-$ & $+1-$ & $+1-$ \\
\hline & Nymphs & $+1-$ & + & & & $+1-$ & $+1-$ \\
\hline & Adults** & & & & & & $+1-$ \\
\hline \multirow{3}{*}{ Manganese } & Snails & & & & + & & \\
\hline & Nymphs*** & & & & + & & \\
\hline & Adults* & & & & + & & \\
\hline \multirow{3}{*}{ Mercury } & Snails & & ++ & & & & \\
\hline & Nymphs & & ++ & & & & \\
\hline & Adults & & ++ & & & & \\
\hline \multirow{3}{*}{ Molybdenum } & Snails & $+1-$ & + & & & & \\
\hline & Nymphs & + & $+1-$ & & & & \\
\hline & Adults & + & & & & & \\
\hline Nickel & Snails & $+1-$ & & & $+1-$ & $+1-$ & \\
\hline
\end{tabular}




\begin{tabular}{|c|c|c|c|c|c|c|c|}
\hline \multirow[t]{3}{*}{ Element $^{2}$} & $\begin{array}{c}\text { Target } \\
\text { invertebrate }^{3}\end{array}$ & Fly ash & $\begin{array}{l}\text { Anthropogenic } \\
\text { source/Clinch } \\
\text { River }\end{array}$ & $\begin{array}{l}\text { Response to } \\
2010 \text { channel } \\
\text { dredging }\end{array}$ & $\begin{array}{c}\text { Natural } \\
\text { background / } \\
\text { geochemical }\end{array}$ & $\begin{array}{l}\text { Anthropogenic } \\
\text { source/Little } \\
\text { Emory River }\end{array}$ & $\begin{array}{l}\text { Unidentified } \\
\text { anthropogenic } \\
\text { sources }\end{array}$ \\
\hline & Nymphs & + & & & \multicolumn{3}{|c|}{$+1-$} \\
\hline & Adults** & & & & & & \\
\hline \multirow{3}{*}{ Selenium } & Snails & ++ & & & & & \\
\hline & Nymphs & ++ & & & & & \\
\hline & Adults & ++ & & & & & \\
\hline \multirow{3}{*}{ Silver } & Snails & & & & & ++ & \\
\hline & Nymphs & & & & & ++ & \\
\hline & Adults & & & & & ++ & \\
\hline \multirow{3}{*}{ Strontium } & Snails & + & + & & & & \\
\hline & Nymphs & + & $+1-$ & & & & \\
\hline & Adults & + & $+1-$ & & & & \\
\hline \multirow{3}{*}{ Thallium } & Snails & ++ & $+1-$ & & & & \\
\hline & Nymphs & ++ & & & & & \\
\hline & Adults $^{4}$ & + & & & & & \\
\hline \multirow{3}{*}{ Vanadium } & Snails & ++ & & $+1-$ & & & \\
\hline & Nymphs & ++ & & & & & \\
\hline & Adults & ++ & & & & & \\
\hline \multirow{3}{*}{ Zinc } & Snails & $+1-$ & $+1-$ & & + & & \\
\hline & Nymphs & & & & + & & $+1-$ \\
\hline & Adults*** & & & & & & \\
\hline \multicolumn{8}{|c|}{$\begin{array}{l}\text { '"++" = highly likely source of element; " }+"=\text { likely source of element; "+/-" = possible source but } \\
\text { uncertain; blank cell = not likely a source. } \\
{ }^{2} \text { Macroelements calcium, magnesium, potassium, and sodium excluded from this analysis; beryllium } \\
\text { excluded due to the large number of samples with concentrations below the method detection limits. } \\
3 " * "=\text { Element not identified as a good candidate for further evaluation; "**" = large number of samples } \\
\text { with concentrations below the method detection limits; "***" = concentrations comparable at all } \\
\text { locations. } \\
{ }^{4} \text { While thallium was not assessed in detail for adult mayflies since several samples had concentrations } \\
\text { below the method detection limit, those sites where thallium was detected were generally those } \\
\text { downstream of the fly ash spill (see Table C.2). }\end{array}$} \\
\hline
\end{tabular}


[THIS PAGE LEFT BLANK INTENTIONALLY] 


\section{UNCERTAINTIES}

Most of the uncertainties associated with the results included in this report have already been addressed. These issues are mainly statistical, such as those associated with the sometimes small sample sizes, especially for analyses of adult mayflies where the number of comparison groups for some analyses were very limited (e.g., comparisons between the subimagos and imagos of females). Small sample sizes and high variation was the primary reason results from 2009 on depurated nymphs were not included in statistical comparisons of spatial or temporal trends.

An additional uncertainty pertains to the quality of some of the results from 2009. The necessity to reanalyze some of the samples due to an analytical error resulted in higher detection limits for some elements. However, those elements most affected were those that were frequently at concentrations that were near or below the method detection limits at several locations, thus, the consequences were negligible.

Most of the elements considered as potential contaminants in fly ash also exist naturally in various natural mineral deposits. Because many invertebrates incidentally ingest inorganic particles while they feed, to better understand the potential contribution of fly ash to body burdens of these elements, a good characterization is needed of the natural geological formations and predominant mineral deposits in the vicinity of the spill site and in the affected watershed upstream of the potential influence of the fly ash spill. 
[THIS PAGE LEFT BLANK INTENTIONALLY] 


\section{REFERENCES}

Dahlgren R. A., and C. T. Driscol. 1994. The effects of whole-tree clear-cutting on soil processes at the Hubbard Brook Experimental Forest, New Hampshire, USA. Plant and Soil 158:239-262.

FOREGS (Forum of European Geological Survey). 2011. Geochemical Baseline Mapping programme. http://www.gsf.fi/publ/foregsatlas/part2.php. Accessed August 1, 2011.

Gensemer, R. W., and R. C. Playle. 1999. The bioavailability and toxicity of aluminum in aquatic environments. Critical Reviews in Environmental Science and Technology 29:315-450.

Mathews, T. J., J. G. Smith, M. J. Peterson, and W. K. Roy. 2011. Assessment of contaminant exposures in invertebrates and fish in waters on and adjacent to the Oak Ridge Reservation - 2010. ORNL/TM2011/108. Oak Ridge National Laboratory, Oak Ridge, TN.

McCune, B., and J. B. Grace. 2002. Analysis of ecological communities. MJM Software Design, Gleneden Beach, OR.

Quinn G. P., and M. J. Keough. 2002. Experimental design and data analysis for biologists. Cambridge University Press, NY.

Rainbow, P.S. 2002. Trace metal concentrations in aquatic invertebrates: why and so what?

Environmental Pollution 120:497-507.

USEPA (US Environmental Protection Agency). 2000. Guidance for Assessing Chemical Contaminant Data for Use in Fish Advisories Volume 1: Fish Sampling and Analysis. Third Edition. EPA 821/B-95001. U. S. Environmental Protection Agency, Office of Water, Washington, DC. 
[THIS PAGE LEFT BLANK INTENTIONALLY] 


\section{APPENDIX A}

MEAN CONCENTRATIONS OF ELEMENTS IN SNAILS 
Table A.1. Mean, standard error of the mean (SE), and maximum (Max) concentrations ( $\mu \mathrm{g} / \mathrm{g}$ dry weight) of bioaccumulative elements (total) of potential ecological concern in snails (Pleurocera canaliculatum) from the Emory River, Clinch River, and Tennessee River, 2009 and 2010. $\mathrm{N}=$ Number of replicate samples.

\begin{tabular}{|c|c|c|c|c|c|c|c|c|c|c|c|c|}
\hline River/site & Year & Depurated $^{1}$ & $\mathrm{~N}$ & Statistic & As & $\mathrm{Cr}$ & $\mathrm{Cu}$ & $\mathrm{Pb}$ & $\mathrm{Hg}$ & $\mathrm{Ni}$ & $\mathrm{Se}$ & $\mathrm{Zn}$ \\
\hline \multicolumn{13}{|c|}{ Emory River } \\
\hline & & & & Mean & 6.73 & 0.50 & 105.9 & 0.47 & 0.058 & 14.3 & 3.00 & 106.1 \\
\hline \multirow[t]{3}{*}{ ERM6.0 } & 2009 & Y & 4 & SE & 0.34 & 0.04 & 5.6 & 0.08 & 0.007 & 1.6 & 0.11 & 4.2 \\
\hline & & & & Max & 7.60 & 0.59 & 121.0 & 0.67 & 0.075 & 18.8 & 3.30 & 115.0 \\
\hline & & & & Mean & 7.73 & 4.90 & 108.8 & 4.67 & 0.134 & 26.0 & 3.23 & 151.7 \\
\hline \multirow[t]{3}{*}{ ERM6.0 } & 2010 & $\mathrm{~N}$ & 3 & SE & 0.82 & 2.60 & 9.4 & 3.32 & 0.022 & 4.0 & 0.38 & 7.2 \\
\hline & & & & $\operatorname{Max}$ & 8.60 & 10.10 & 127.0 & 11.30 & 0.160 & 32.7 & 3.80 & 166.0 \\
\hline & & & & Mean & 9.00 & 0.99 & 143.7 & 0.51 & 0.163 & 43.0 & 3.43 & 142.0 \\
\hline \multirow[t]{3}{*}{ ERM6.0 } & 2010 & Y & 3 & SE & 0.15 & 0.21 & 12.0 & 0.24 & 0.015 & 14.1 & 0.23 & 14.5 \\
\hline & & & & Max & 9.20 & 1.40 & 167.0 & 0.99 & 0.190 & 71.1 & 3.90 & 171.0 \\
\hline & & & & Mean & 10.57 & 0.72 & 125.7 & 0.37 & 0.085 & 31.4 & 3.83 & 205.3 \\
\hline \multirow[t]{3}{*}{ ERM4.0 } & 2010 & Y & 3 & SE & 0.15 & 0.19 & 4.1 & 0.01 & 0.008 & 4.0 & 0.09 & 17.1 \\
\hline & & & & Max & 10.80 & 1.10 & 132.0 & 0.38 & 0.100 & 38.8 & 4.00 & 236.0 \\
\hline & & & & Mean & 8.43 & 0.68 & 86.5 & 0.44 & 0.053 & 23.8 & 3.78 & 104.8 \\
\hline \multirow[t]{3}{*}{ ERM2.5 } & 2009 & $\mathrm{Y}$ & 4 & SE & 0.23 & 0.11 & 5.2 & 0.03 & 0.002 & 0.8 & 0.05 & 5.5 \\
\hline & & & & Max & 9.00 & 1.00 & 94.2 & 0.51 & 0.059 & 25.7 & 3.90 & 113.0 \\
\hline & & & & Mean & 11.93 & 5.53 & 113.0 & 3.30 & 0.098 & 26.1 & 3.73 & 116.8 \\
\hline \multirow[t]{3}{*}{ ERM2.5 } & 2010 & $\mathrm{~N}$ & 3 & SE & 0.90 & 0.71 & 5.7 & 0.53 & 0.013 & 6.3 & 0.26 & 15.1 \\
\hline & & & & Max & 13.60 & 6.90 & 121.0 & 4.10 & 0.120 & 35.9 & 4.20 & 140.0 \\
\hline & & & & Mean & 11.57 & 0.72 & 145.0 & 0.38 & 0.084 & 22.2 & 4.10 & 125.3 \\
\hline \multirow[t]{2}{*}{ ERM2.5 } & 2010 & Y & 3 & SE & 0.76 & 0.01 & 21.2 & 0.01 & 0.001 & 0.2 & 0.20 & 0.3 \\
\hline & & & & Max & 13.00 & 0.74 & 184.0 & 0.40 & 0.085 & 22.5 & 4.50 & 126.0 \\
\hline \multirow{3}{*}{ ERM1.0 } & & & & Mean & 10.20 & 1.19 & 107.6 & 0.35 & 0.061 & 24.6 & 5.45 & 179.0 \\
\hline & 2009 & Y & 4 & SE & 0.89 & 0.26 & 8.0 & 0.05 & 0.010 & 5.7 & 0.33 & 28.1 \\
\hline & & & & $\operatorname{Max}$ & 12.00 & 1.80 & 118.0 & 0.48 & 0.081 & 37.4 & 6.10 & 246.0 \\
\hline & & & & Mean & 12.70 & 3.83 & 134.7 & 1.77 & 0.112 & 26.2 & 5.27 & 158.7 \\
\hline \multirow[t]{3}{*}{ ERM1.0 } & 2010 & $\mathrm{~N}$ & 3 & SE & 0.61 & 0.39 & 21.4 & 0.15 & 0.010 & 2.3 & 0.30 & 23.7 \\
\hline & & & & $\operatorname{Max}$ & 13.90 & 4.60 & 175.0 & 2.00 & 0.130 & 30.7 & 5.70 & 204.0 \\
\hline & & & & Mean & 13.23 & 2.01 & 135.3 & 0.28 & 0.087 & 36.6 & 5.53 & 226.7 \\
\hline \multirow[t]{2}{*}{ ERM1.0 } & 2010 & Y & 3 & SE & 0.90 & 0.60 & 16.2 & 0.02 & 0.012 & 8.7 & 0.52 & 36.2 \\
\hline & & & & Max & 14.70 & 3.00 & 152.0 & 0.32 & 0.100 & 52.0 & 6.10 & 292.0 \\
\hline \multicolumn{13}{|c|}{ Clinch River } \\
\hline & & & & Mean & 10.78 & 1.78 & 118.6 & 0.47 & 0.130 & 16.9 & 4.33 & 142.0 \\
\hline \multirow[t]{2}{*}{ CRM6.0 } & 2009 & Y & 4 & SE & 0.55 & 0.40 & 13.6 & 0.04 & 0.010 & 0.5 & 0.17 & 4.4 \\
\hline & & & & Max & 11.60 & 2.80 & 149.0 & 0.57 & 0.160 & 18.3 & 4.70 & 152.0 \\
\hline & & & & Mean & 13.53 & 3.13 & 155.0 & 1.56 & 0.273 & 17.0 & 4.53 & 136.3 \\
\hline \multirow[t]{2}{*}{ CRM6.0 } & 2010 & $\mathrm{~N}$ & 3 & SE & 0.47 & 0.35 & 5.3 & 0.88 & 0.012 & 1.1 & 0.15 & 1.9 \\
\hline & & & & Max & 14.10 & 3.70 & 165.0 & 3.30 & 0.290 & 18.8 & 4.80 & 140.0 \\
\hline & & & & Mean & 16.73 & 3.17 & 201.3 & 0.58 & 0.280 & 25.1 & 4.73 & 174.0 \\
\hline \multirow[t]{3}{*}{ CRM6.0 } & 2010 & Y & 3 & SE & 0.80 & 0.22 & 14.7 & 0.15 & 0.026 & 1.8 & 0.09 & 19.8 \\
\hline & & & & Max & 17.90 & 3.60 & 226.0 & 0.87 & 0.330 & 28.2 & 4.90 & 213.0 \\
\hline & & & & Mean & 14.23 & 3.77 & 155.0 & 1.44 & 0.130 & 17.1 & 5.60 & 160.7 \\
\hline \multirow[t]{2}{*}{ CRM3.5 } & 2010 & $\mathrm{~N}$ & 3 & SE & 0.48 & 0.29 & 10.8 & 0.63 & 0.015 & 1.4 & 0.62 & 7.5 \\
\hline & & & & $\operatorname{Max}$ & 15.20 & 4.30 & 170.0 & 2.60 & 0.150 & 19.0 & 6.80 & 171.0 \\
\hline
\end{tabular}




\begin{tabular}{|c|c|c|c|c|c|c|c|c|c|c|c|c|}
\hline River/site & Year & epurated ${ }^{1}$ & $\mathrm{~N}$ & Statistic & As & $\mathrm{Cr}$ & $\mathrm{Cu}$ & $\mathrm{Pb}$ & $\mathrm{Hg}$ & $\mathrm{Ni}$ & Se & $\mathrm{Zn}$ \\
\hline & & & & Mean & 14.47 & 3.07 & 172.0 & 0.34 & 0.143 & 28.1 & 6.07 & 208.3 \\
\hline \multirow[t]{2}{*}{ CRM3.5 } & 2010 & Y & 3 & SE & 2.32 & 0.90 & 16.7 & 0.02 & 0.023 & 3.6 & 0.80 & 11.3 \\
\hline & & & & $\operatorname{Max}$ & 17.80 & 4.70 & 196.0 & 0.37 & 0.180 & 35.1 & 7.10 & 227.0 \\
\hline \multirow{3}{*}{ CRM1.5 } & & & & Mean & 10.55 & 1.22 & 97.6 & 0.29 & 0.068 & 17.8 & 4.95 & 145.5 \\
\hline & 2009 & $\mathrm{Y}$ & 4 & SE & 0.39 & 0.43 & 7.7 & 0.03 & 0.008 & 3.2 & 0.50 & 5.5 \\
\hline & & & & Max & 11.70 & 2.50 & 110.0 & 0.36 & 0.082 & 27.4 & 6.30 & 160.0 \\
\hline & & & & Mean & 16.60 & 5.30 & 138.7 & 2.73 & 0.220 & 35.5 & 6.63 & 192.0 \\
\hline \multirow[t]{2}{*}{ CRM1.5 } & 2010 & $\mathrm{~N}$ & 3 & SE & 2.57 & 1.14 & 19.1 & 2.04 & 0.015 & 6.0 & 1.17 & 33.2 \\
\hline & & & & $\operatorname{Max}$ & 20.10 & 7.10 & 166.0 & 6.80 & 0.240 & 44.1 & 7.90 & 236.0 \\
\hline \multirow{3}{*}{ CRM1.5 } & & & & Mean & 16.23 & 3.57 & 189.7 & 0.67 & 0.177 & 36.9 & 6.77 & 191.7 \\
\hline & 2010 & Y & 3 & SE & 2.51 & 1.18 & 23.0 & 0.16 & 0.024 & 9.3 & 1.62 & 35.1 \\
\hline & & & & $\operatorname{Max}$ & 19.80 & 4.80 & 217.0 & 0.90 & 0.210 & 49.4 & 9.20 & 246.0 \\
\hline \multicolumn{13}{|c|}{ Little Emory River } \\
\hline & & & & Mean & 10.87 & 1.11 & 127.3 & 0.21 & 0.186 & 15.6 & 5.27 & 148.7 \\
\hline \multirow[t]{2}{*}{ LERM1.0 } & 2010 & Y & 3 & SE & 1.89 & 0.56 & 17.4 & 0.02 & 0.045 & 3.9 & 0.81 & 17.0 \\
\hline & & & & $\operatorname{Max}$ & 13.50 & 2.20 & 157.0 & 0.24 & 0.250 & 19.9 & 6.40 & 170.0 \\
\hline \multicolumn{13}{|c|}{ Tennessee River } \\
\hline \multirow{3}{*}{ TRM572.5 } & & & & Mean & 5.33 & 0.41 & 110.3 & 0.27 & 0.043 & 5.7 & 2.23 & 118.3 \\
\hline & 2010 & Y & 3 & SE & 0.27 & 0.06 & 3.3 & 0.03 & 0.002 & 0.5 & 0.07 & 1.2 \\
\hline & & & & Max & 5.70 & 0.52 & 117.0 & 0.33 & 0.046 & 6.5 & 2.30 & 120.0 \\
\hline \multirow{3}{*}{ TRM566.3 } & & & & Mean & 9.50 & 1.27 & 107.2 & 0.26 & 0.125 & 10.1 & 3.43 & 144.0 \\
\hline & 2010 & Y & 3 & SE & 0.90 & 0.23 & 6.0 & 0.01 & 0.016 & 0.8 & 0.12 & 1.2 \\
\hline & & & & $\operatorname{Max}$ & 11.30 & 1.70 & 119.0 & 0.29 & 0.150 & 11.3 & 3.60 & 146.0 \\
\hline
\end{tabular}

analysis. 
Table A.2. Mean, standard error of the mean (SE), and maximum (Max) concentrations ( $\mu \mathrm{g} / \mathrm{g}$ dry weight) of elements (total) of potential ecological concern (excluding those of bioaccumulative concern) in snails (Pleurocera canaliculatum) from the Emory River, Clinch River,

and Tennessee River, 2009 and 2010. $\mathrm{N}=$ Number of replicate samples. Values for means proceeded by a " $<$ " symbol indicate that concentrations for all replicates were below the method detection limit (MDL); the numeral after the "<" symbol is the highest MDL reported among all replicates from a sample. Observations with mean and maximum concentrations but no SE indicate that the concentration was below

\begin{tabular}{|c|c|c|c|c|c|c|c|c|c|c|c|c|c|c|c|c|c|}
\hline River/site & ear & Depurated $^{1}$ & $\mathrm{~N}$ & Statistic & $\mathrm{Al}$ & $\mathrm{Sb}$ & $\mathrm{Ba}$ & $\mathrm{Be}$ & $B$ & $\mathrm{Cd}$ & Co & $\mathrm{Mn}$ & Mo & $\mathrm{Ag}$ & $\mathrm{Sr}$ & TI & $V$ \\
\hline \multicolumn{18}{|c|}{ Emory River } \\
\hline & & & & Mean & 15.6 & $<0.019$ & 18.0 & 0.0072 & 1.05 & 0.53 & 5.00 & 195.0 & 0.43 & 0.743 & 26.0 & 0.024 & 0.14 \\
\hline \multirow[t]{3}{*}{ ERM6.0 } & 2009 & $\mathrm{Y}$ & 4 & SE & 4.2 & & 1.9 & 0.0009 & 0.22 & 0.04 & 0.38 & 21.3 & 0.04 & 0.092 & 2.7 & 0.007 & 0.03 \\
\hline & & & & $\operatorname{Max}$ & 24.3 & & 23.1 & 0.0095 & 1.60 & 0.63 & 6.10 & 249.0 & 0.49 & 0.940 & 33.5 & 0.037 & 0.22 \\
\hline & & & & Mean & 1466.7 & 0.104 & 47.4 & 0.1013 & 3.73 & 0.87 & 10.80 & 572.7 & 0.60 & 1.050 & 38.6 & 0.119 & 2.93 \\
\hline \multirow[t]{3}{*}{ ERM6.0 } & 2010 & $\mathrm{~N}$ & 3 & SE & 78.4 & 0.078 & 3.9 & 0.0045 & 0.55 & 0.07 & 1.21 & 27.2 & 0.05 & 0.075 & 2.3 & 0.013 & 0.44 \\
\hline & & & & Max & 1550.0 & 0.260 & 52.0 & 0.1100 & 4.70 & 1.00 & 12.30 & 627.0 & 0.69 & 1.200 & 43.1 & 0.140 & 3.80 \\
\hline & & & & Mean & 8.8 & 0.028 & 26.8 & $<0.038$ & 2.03 & 1.17 & 14.87 & 496.0 & 0.59 & 1.253 & 35.3 & 0.037 & 0.28 \\
\hline \multirow[t]{3}{*}{ ERM6.0 } & 2010 & $Y$ & 3 & SE & 1.1 & 0.011 & 1.7 & . & 0.38 & 0.26 & 3.77 & 46.7 & 0.06 & 0.187 & 2.2 & 0.002 & 0.02 \\
\hline & & & & Max & 10.9 & 0.038 & 29.9 & . & 2.70 & 1.70 & 22.40 & 585.0 & 0.69 & 1.600 & 39.7 & 0.041 & 0.31 \\
\hline & & & & Mean & 121.2 & $<0.019$ & 29.3 & 0.0345 & 2.50 & 1.27 & 10.13 & 332.3 & 0.55 & 0.817 & 49.6 & 0.133 & 0.47 \\
\hline \multirow[t]{3}{*}{ ERM4.0 } & 2010 & $Y$ & 3 & SE & 47.5 & & 1.5 & 0.0035 & 0.17 & 0.12 & 1.39 & 23.0 & 0.02 & 0.097 & 1.0 & 0.012 & 0.06 \\
\hline & & & & Max & 182.0 & . & 32.1 & 0.0380 & 2.80 & 1.50 & 12.80 & 365.0 & 0.58 & 1.000 & 51.1 & 0.150 & 0.57 \\
\hline & & & & Mean & 11.4 & $<0.019$ & 19.6 & 0.0064 & 1.48 & 0.77 & 10.88 & 188.8 & 0.51 & 0.140 & 35.9 & 15 & 0.15 \\
\hline \multirow[t]{3}{*}{ ERM2.5 } & 2009 & $\mathrm{Y}$ & 4 & SE & 1.5 & . & 3.3 & 0.0007 & 0.17 & 0.02 & 0.61 & 11.0 & 0.01 & 0.018 & 5.6 & 0.008 & 0.02 \\
\hline & & & & $\operatorname{Max}$ & 14.2 & . & 26.0 & 0.0074 & 1.90 & 0.80 & 12.20 & 221.0 & 0.53 & 0.170 & 47.9 & 0.130 & 0.20 \\
\hline & & & & Mean & 3690.0 & $0.087^{2}$ & 50.2 & 0.2233 & 8.13 & 1.08 & 11.77 & 530.3 & 0.60 & 0.253 & 45.2 & 0.390 & 6.43 \\
\hline \multirow[t]{3}{*}{ ERM2.5 } & 2010 & $\mathrm{~N}$ & 3 & SE & 560.8 & 0.014 & 8.9 & 0.0437 & 0.91 & 0.25 & 3.37 & 145.4 & 0.07 & 0.030 & 1.9 & 0.006 & 1.00 \\
\hline & & & & Max & 4630.0 & 0.100 & 66.7 & 0.3100 & 9.50 & 1.50 & 18.10 & 817.0 & 0.74 & 0.310 & 47.8 & 0.400 & 8.40 \\
\hline & & & & Mean & 42.2 & 0.019 & 24.1 & 0.0350 & 1.83 & 1.47 & 8.30 & 253.0 & 0.67 & 0.387 & 40.9 & 0.260 & 0.40 \\
\hline \multirow[t]{3}{*}{ ERM2.5 } & 2010 & Y & 3 & SE & 23.1 & 0.001 & 2.0 & . & 0.13 & 0.23 & 0.30 & 20.6 & 0.10 & 0.041 & 3.5 & 0.010 & 0.05 \\
\hline & & & & $\operatorname{Max}$ & 87.5 & 0.021 & 26.1 & 0.0350 & 2.10 & 1.90 & 8.90 & 291.0 & 0.84 & 0.450 & 45.9 & 0.280 & 0.46 \\
\hline & & & & Mean & 56.8 & $0.021^{2}$ & 18.6 & 0.0190 & 1.28 & 1.14 & 11.15 & 246.3 & 0.60 & 0.062 & 41.9 & 0.345 & 0.84 \\
\hline \multirow[t]{3}{*}{ ERM1.0 } & 2009 & Y & 4 & SE & 12.7 & 0.003 & 2.1 & 0.0051 & 0.19 & 0.07 & 2.42 & 84.9 & 0.10 & 0.020 & 4.9 & 0.021 & 0.30 \\
\hline & & & & $\operatorname{Max}$ & 92.2 & & 24.1 & & 1.80 & 1.30 & 16.00 & 449.0 & 0.80 & 0.099 & 52.7 & 390 & 1.50 \\
\hline & & & & Mean & 2123.3 & & 39.8 & & 3.13 & 1.53 & 13.17 & 409.3 & 0.56 & 0.079 & 49.4 & 0.543 & 4.87 \\
\hline \multirow[t]{2}{*}{ ERM1.0 } & 2010 & $\mathrm{~N}$ & 3 & SE & 84.1 & 0.007 & 1.7 & 0.0088 & 0.22 & 0.15 & 2.15 & 86.3 & 0.09 & 0.011 & 3.1 & 0.017 & 0.55 \\
\hline & & & & $\operatorname{Max}$ & 2240.0 & 0.091 & 42.4 & 0.1600 & 3.40 & 1.80 & 17.30 & 505.0 & 0.73 & 0.100 & 55.6 & 0.560 & 5.80 \\
\hline \multirow{3}{*}{ ERM1.0 } & & & & Mean & 27.8 & 0.029 & 16.9 & $<0.03$ & 1.17 & 1.40 & 16.63 & 379.0 & 0.59 & 0.061 & 29.9 & 0.370 & 1.23 \\
\hline & 2010 & $Y$ & 3 & SE & 4.5 & 0.004 & 2.2 & . & 0.29 & 0.12 & 4.10 & 112.3 & 0.11 & 0.003 & 2.6 & 0.036 & 0.32 \\
\hline & & & & Max & 35.0 & 0.034 & 21.1 & . & 1.70 & 1.60 & 24.50 & 543.0 & 0.75 & 0.067 & 34.6 & 0.440 & 1.60 \\
\hline
\end{tabular}




\begin{tabular}{|c|c|c|c|c|c|c|c|c|c|c|c|c|c|c|c|c|c|}
\hline River/site & Year & Depurated $^{1}$ & $\mathrm{~N}$ & Statistic & $\mathrm{Al}$ & $\mathrm{Sb}$ & $\mathrm{Ba}$ & $\mathrm{Be}$ & B & $\mathrm{Cd}$ & Co & Mn & Mo & $\mathrm{Ag}$ & $\mathrm{Sr}$ & $\mathrm{Tl}$ & V \\
\hline \multicolumn{18}{|l|}{ Clinch River } \\
\hline & & & & Mean & 20.9 & $<0.019$ & 14.7 & $0.0047^{2}$ & 0.98 & 1.08 & 6.13 & 120.1 & 0.64 & 0.168 & 34.4 & 0.173 & 0.26 \\
\hline \multirow[t]{3}{*}{ CRM6.0 } & 2009 & $\mathrm{Y}$ & 4 & SE & 6.6 & . & 1.8 & 0.0006 & 0.26 & 0.13 & 0.51 & 11.9 & 0.02 & 0.013 & 2.6 & 0.003 & 0.02 \\
\hline & & & & Max & 39.9 & . & 19.3 & 0.0056 & 1.60 & 1.30 & 7.10 & 150.0 & 0.68 & 0.200 & 40.0 & 0.180 & 0.31 \\
\hline & & & & Mean & 579.3 & 0.027 & 31.9 & 0.0560 & 1.87 & 1.42 & 7.13 & 248.3 & 0.83 & 0.170 & 55.6 & 0.297 & 1.81 \\
\hline \multirow[t]{3}{*}{ CRM6.0 } & 2010 & $\mathrm{~N}$ & 3 & SE & 250.0 & 0.005 & 6.4 & . & 0.03 & 0.30 & 0.85 & 52.0 & 0.01 & 0.015 & 3.8 & 0.046 & 0.71 \\
\hline & & & & Max & 1060.0 & 0.037 & 44.7 & 0.0560 & 1.90 & 2.00 & 8.80 & 322.0 & 0.85 & 0.190 & 63.0 & 0.380 & 3.20 \\
\hline & & & & Mean & 8.6 & 0.020 & 27.1 & $<0.031$ & 1.15 & 3.10 & 9.33 & 215.0 & 0.98 & 0.250 & 58.3 & 0.253 & 0.75 \\
\hline \multirow[t]{3}{*}{ CRM6.0 } & 2010 & $Y$ & 3 & SE & 1.8 & 0.001 & 4.2 & . & 0.16 & 1.52 & 1.27 & 51.5 & 0.06 & 0.056 & 6.1 & 0.018 & 0.05 \\
\hline & & & & Max & 12.0 & 0.021 & 35.0 & . & 1.40 & 6.10 & 11.60 & 318.0 & 1.10 & 0.360 & 68.2 & 0.280 & 0.82 \\
\hline & & & & Mean & 1185.0 & $0.064^{2}$ & 28.2 & $0.1175^{2}$ & 2.60 & 1.73 & 6.77 & 359.7 & 0.91 & 0.110 & 45.0 & 0.460 & 3.47 \\
\hline \multirow[t]{3}{*}{ CRM3.5 } & 2010 & $\mathrm{~N}$ & 3 & SE & 525.7 & 0.016 & 5.9 & 0.0425 & 0.36 & 0.18 & 0.88 & 71.3 & 0.10 & 0.010 & 1.6 & 0.035 & 1.05 \\
\hline & & & & Max & 2050.0 & 0.080 & 37.8 & 0.1600 & 3.30 & 2.00 & 8.10 & 450.0 & 1.10 & 0.130 & 47.7 & 0.520 & 5.40 \\
\hline & & & & Mean & 12.4 & 0.022 & 24.5 & $<0.03$ & 1.20 & 2.03 & 11.47 & 355.0 & 0.86 & 0.110 & 55.3 & 0.360 & 1.25 \\
\hline \multirow[t]{3}{*}{ CRM3.5 } & 2010 & $\mathrm{Y}$ & 3 & SE & 1.8 & 0.002 & 1.6 & . & 0.00 & 0.32 & 0.87 & 27.5 & 0.16 & 0.025 & 3.8 & 0.049 & 0.21 \\
\hline & & & & Max & 15.3 & 0.027 & 27.5 & . & 1.20 & 2.40 & 13.20 & 409.0 & 1.10 & 0.140 & 60.7 & 0.440 & 1.60 \\
\hline & & & & Mean & 17.4 & $<0.019$ & 11.0 & 0.0059 & 1.00 & 1.19 & 7.35 & 252.0 & 0.74 & 0.072 & 28.5 & 0.215 & 0.74 \\
\hline \multirow[t]{3}{*}{ CRM1.5 } & 2009 & $\mathrm{Y}$ & 4 & SE & 6.8 & . & 0.9 & 0.0010 & 0.24 & 0.17 & 0.63 & 39.9 & 0.06 & 0.019 & 1.2 & 0.023 & 0.21 \\
\hline & & & & Max & 37.2 & . & 12.7 & 0.0081 & 1.60 & 1.70 & 8.30 & 348.0 & 0.92 & 0.130 & 31.6 & 0.270 & 1.10 \\
\hline & & & & Mean & 438.7 & 0.040 & 32.1 & $0.0500^{2}$ & 2.37 & 3.83 & 13.00 & 579.0 & 0.82 & 0.242 & 57.3 & 0.500 & 2.27 \\
\hline \multirow[t]{3}{*}{ CRM1.5 } & 2010 & $\mathrm{~N}$ & 3 & SE & 127.6 & 0.005 & 4.7 & 0.0030 & 0.45 & 1.07 & 1.57 & 136.8 & 0.09 & 0.079 & 4.4 & 0.044 & 0.37 \\
\hline & & & & Max & 590.0 & 0.048 & 40.6 & 0.0530 & 3.00 & 5.00 & 16.10 & 814.0 & 0.98 & 0.370 & 65.2 & 0.570 & 3.00 \\
\hline & & & & Mean & 17.9 & 0.022 & 23.6 & $<0.038$ & 1.60 & 3.53 & 13.03 & 526.0 & 0.85 & 0.228 & 53.6 & 0.360 & 1.22 \\
\hline \multirow[t]{2}{*}{ CRM1.5 } & 2010 & $\mathrm{Y}$ & 3 & SE & 8.8 & 0.004 & 3.0 & . & 0.32 & 1.13 & 2.82 & 78.9 & 0.08 & 0.087 & 2.0 & 0.035 & 0.33 \\
\hline & & & & Max & 35.4 & 0.026 & 28.8 & . & 2.20 & 5.40 & 16.20 & 636.0 & 0.98 & 0.330 & 57.1 & 0.400 & 1.60 \\
\hline \multicolumn{18}{|c|}{ Little Emory River } \\
\hline & & & & Mean & 8.6 & $<0.018$ & 28.9 & $<0.036$ & 2.60 & 1.04 & 3.93 & 247.0 & 0.56 & 4.033 & 39.8 & 0.049 & 0.28 \\
\hline \multirow[t]{2}{*}{ LERM1.0 } & 2010 & $\mathrm{Y}$ & 3 & SE & 1.2 & . & 6.3 & . & 0.56 & 0.22 & 1.12 & 65.7 & 0.09 & 1.313 & 5.7 & 0.005 & 0.08 \\
\hline & & & & Max & 10.3 & . & 35.9 & . & 3.30 & 1.30 & 5.20 & 337.0 & 0.70 & 5.900 & 49.3 & 0.057 & 0.44 \\
\hline \multicolumn{18}{|c|}{ Tennessee River } \\
\hline \multirow{4}{*}{ TRM572.5 } & & & & Mean & 9.8 & 0.014 & 11.2 & $<0.03$ & 1.60 & 0.58 & 6.20 & 214.0 & 0.59 & 0.553 & 37.7 & 0.030 & 0.28 \\
\hline & 2010 & $\mathrm{Y}$ & 3 & SE & 4.3 & . & 0.8 & . & 0.06 & 0.03 & 0.56 & 37.9 & 0.06 & 0.090 & 5.5 & 0.002 & 0.03 \\
\hline & & & & Max & 18.3 & 0.014 & 12.4 & . & 1.70 & 0.64 & 7.30 & 288.0 & 0.65 & 0.680 & 45.2 & 0.035 & 0.32 \\
\hline & & & & Mean & 8.9 & 0.022 & 21.0 & $<0.031$ & 1.60 & 1.16 & 6.17 & 258.0 & 0.97 & 0.193 & 44.9 & 0.147 & 0.49 \\
\hline \multirow[t]{2}{*}{ TRM566.3 } & 2010 & $\mathrm{Y}$ & 3 & SE & 0.6 & . & 0.3 & . & 0.23 & 0.15 & 0.50 & 18.0 & 0.14 & 0.029 & 3.3 & 0.013 & 0.04 \\
\hline & & & & Max & 9.8 & 0.022 & 21.7 & . & 2.00 & 1.40 & 6.90 & 294.0 & 1.20 & 0.240 & 48.3 & 0.160 & 0.54 \\
\hline
\end{tabular}

" "N" = snails were not depurated prior to analysis; "Y" = snails were depurated for $72 \mathrm{hr}$ prior to analysis.

${ }^{2}$ Only 2 replicates had concentrations above the method detection limit; descriptive statistics based on only those 2 replicates. 
Table A.3. Mean, standard error of the mean (SE), and maximum (Max) concentrations ( $\mu \mathrm{g} / \mathrm{g}$ dry weight) of major cations and iron (total) in snails (Pleurocera canaliculatum) from the Emory River,

Clinch River, and Tennessee River, 2009 and 2010. $\mathrm{N}=$ Number of replicate samples. Values for means proceeded by a "<" symbol indicate that concentrations for all replicates were below the method detection limit (MDL); the numeral after the "<" symbol is the highest MDL report among all replicates 


\begin{tabular}{|c|c|c|c|c|c|c|c|c|c|}
\hline River/site & Year & Depurated $^{1}$ & $\mathrm{~N}$ & Statistic & $\mathrm{Ca}$ & $\mathrm{Fe}$ & $\mathrm{Mg}$ & $\mathrm{K}$ & $\mathrm{Na}$ \\
\hline & & & & Mean & 36666.7 & 1274.3 & 12433.3 & 4653.3 & 2506.7 \\
\hline \multirow[t]{2}{*}{ CRM3.5 } & 2010 & $\mathrm{~N}$ & 3 & SE & 788.1 & 439.1 & 1266.7 & 80.1 & 74.2 \\
\hline & & & & Max & 37900.0 & 2000.0 & 14900.0 & 4770.0 & 2600.0 \\
\hline & & & & Mean & 45766.7 & 581.7 & 12766.7 & 3826.7 & 1080.3 \\
\hline \multirow[t]{2}{*}{ CRM3.5 } & 2010 & $Y$ & 3 & SE & 3146.6 & 64.2 & 1128.9 & 269.6 & 233.6 \\
\hline & & & & Max & 49400.0 & 680.0 & 14400.0 & 4190.0 & 1490.0 \\
\hline & & & & Mean & 24150.0 & 346.8 & 9280.0 & 3540.0 & 702.3 \\
\hline \multirow[t]{2}{*}{ CRM1.5 } & 2009 & $Y$ & 4 & SE & 1103.4 & 19.2 & 620.4 & 67.8 & 57.6 \\
\hline & & & & Max & 27400.0 & 376.0 & 10500.0 & 3740.0 & 856.0 \\
\hline & & & & Mean & 46400.0 & 1084.0 & 14700.0 & 4503.3 & 3150.0 \\
\hline \multirow[t]{2}{*}{ CRM1.5 } & 2010 & $\mathrm{~N}$ & 3 & SE & 1835.8 & 189.3 & 702.4 & 237.0 & 431.0 \\
\hline & & & & $\operatorname{Max}$ & 49300.0 & 1460.0 & 15500.0 & 4850.0 & 3790.0 \\
\hline \multirow{3}{*}{ CRM1.5 } & & & & Mean & 43566.7 & 629.7 & 14666.7 & 4053.3 & 1350.0 \\
\hline & 2010 & $Y$ & 3 & SE & 1146.5 & 121.2 & 1083.7 & 491.7 & 272.1 \\
\hline & & & & Max & 45800.0 & 790.0 & 15800.0 & 4560.0 & 1800.0 \\
\hline \multicolumn{10}{|c|}{ Little Emory River } \\
\hline \multirow{3}{*}{ LERM1.0 } & & & & Mean & 34400.0 & 560.7 & 11733.3 & 3996.7 & 2820.0 \\
\hline & 2010 & Y & 3 & SE & 4772.1 & 157.6 & 717.2 & 37.6 & 567.0 \\
\hline & & & & Max & 42000.0 & 774.0 & 12500.0 & 4060.0 & 3680.0 \\
\hline \multicolumn{10}{|c|}{ Tennessee River } \\
\hline \multirow{3}{*}{ TRM572.5 } & & & & Mean & 29966.7 & 295.0 & 10110.0 & 3626.7 & 1065.3 \\
\hline & 2010 & Y & 3 & SE & 3502.5 & 30.3 & 844.5 & 33.8 & 107.9 \\
\hline & & & & Max & 34600.0 & 355.0 & 11100.0 & 3670.0 & 1280.0 \\
\hline \multirow{3}{*}{ TRM566.3 } & & & & Mean & 36300.0 & 408.0 & 13433.3 & 3746.7 & 1736.7 \\
\hline & 2010 & Y & 3 & SE & 3153.3 & 16.8 & 1126.0 & 48.1 & 136.4 \\
\hline & & & & Max & 40400.0 & 436.0 & 14800.0 & 3840.0 & 1920.0 \\
\hline
\end{tabular}
analysis. 


\section{APPENDIX B}

\section{MEAN CONCENTRATIONS OF ELEMENTS IN MAYFLY NYMPHS}


Table B.1. Mean, standard error of the mean (SE), and maximum (Max) concentrations ( $\mu \mathrm{g} / \mathrm{g}$ dry weight) of bioaccumulative elements (total) of potential ecological concern in mayfly nymphs

(Hexagenia bilineata) from the Emory River, Clinch River, and Tennessee River, 2009 and 2010. N

$=$ Number of replicate samples. Values for means proceeded by a "<" symbol indicate that concentrations for all replicates were below the method detection limit (MDL); the numeral after the "<" symbol is the

highest MDL report among all replicates from a sample.

\begin{tabular}{|c|c|c|c|c|c|c|c|c|c|c|c|c|}
\hline River/site & Year & Depurated $^{1}$ & $\mathrm{~N}$ & Statistic & As & $\mathrm{Cr}$ & $\mathrm{Cu}$ & $\mathrm{Pb}$ & $\mathrm{Hg}$ & $\mathrm{Ni}$ & $\mathrm{Se}$ & $\mathrm{Zn}$ \\
\hline \multicolumn{13}{|c|}{ Emory River } \\
\hline \multirow{3}{*}{ ERM6.0 } & \multirow{3}{*}{2009} & \multirow{3}{*}{$\mathrm{N}$} & \multirow{3}{*}{4} & Mean & 2.93 & 4.85 & 10.25 & 0.057 & 5.5 & 4.60 & 1.98 & 184.3 \\
\hline & & & & SE & 0.18 & 0.38 & 0.32 & 0.003 & 0.57 & 0.37 & 0.05 & 6.7 \\
\hline & & & & Max & 3.30 & 5.50 & 11.10 & 0.062 & 6.9 & 5.10 & 2.10 & 199.0 \\
\hline & & & & Mean & 3.00 & 5.87 & 10.13 & 0.059 & 6.3 & 6.03 & 2.83 & 177.0 \\
\hline \multirow[t]{2}{*}{ ERM6.0 } & \multirow[t]{2}{*}{2010} & \multirow[t]{2}{*}{$\mathrm{N}$} & \multirow[t]{2}{*}{3} & SE & 0.12 & 0.66 & 0.33 & 0.002 & 0.52 & 0.46 & 0.19 & 7.2 \\
\hline & & & & Max & 3.20 & 6.80 & 10.60 & 0.061 & 7.0 & 6.80 & 3.20 & 191.0 \\
\hline \multirow{3}{*}{ ERM6.0 } & \multirow{3}{*}{2010} & \multirow{3}{*}{$Y$} & \multirow{3}{*}{3} & Mean & 0.95 & 1.00 & 31.67 & 0.043 & 1.5 & 2.37 & 2.40 & 250.7 \\
\hline & & & & SE & 0.08 & 0.25 & 0.87 & 0.003 & 0.32 & 0.23 & 0.15 & 3.8 \\
\hline & & & & Max & 1.10 & 1.50 & 33.10 & 0.048 & 2.1 & 2.80 & 2.70 & 255.0 \\
\hline \multirow{3}{*}{ ERM4.0 } & \multirow{3}{*}{2010} & \multirow{3}{*}{$\mathrm{N}$} & \multirow{3}{*}{3} & Mean & 7.37 & 6.53 & 12.07 & 0.068 & 8.8 & 6.10 & 4.57 & 187.7 \\
\hline & & & & SE & 0.38 & 0.33 & 0.52 & 0.002 & 0.42 & 0.12 & 0.38 & 18.7 \\
\hline & & & & $\operatorname{Max}$ & 8.10 & 7.20 & 13.10 & 0.071 & 9.6 & 6.30 & 5.00 & 217.0 \\
\hline \multirow{3}{*}{ ERM4.0 } & \multirow{3}{*}{2010} & & & Mean & 3.10 & 1.31 & 35.77 & 0.058 & 1.9 & 3.07 & 3.73 & 237.3 \\
\hline & & $Y$ & 3 & SE & 0.29 & 0.26 & 1.64 & 0.002 & 0.33 & 0.24 & 0.23 & 2.9 \\
\hline & & & & Max & 3.60 & 1.70 & 37.60 & 0.063 & 2.4 & 3.40 & 4.10 & 242.0 \\
\hline & & & & Mean & 14.30 & 8.78 & 17.76 & 0.073 & 11.6 & 7.50 & 4.58 & 193.2 \\
\hline ERM2.5 & 2009 & $\mathrm{~N}$ & 5 & SE & 1.31 & 0.79 & 0.62 & 0.008 & 0.97 & 0.84 & 0.34 & 18.7 \\
\hline & & & & Max & 16.90 & 11.20 & 20.20 & 0.088 & 14.9 & 10.40 & 5.40 & 249.0 \\
\hline & & & & Mean & 14.87 & 11.63 & 18.83 & 0.077 & 14.8 & 9.13 & 7.00 & 180.0 \\
\hline ERM2.5 & 2010 & $\mathrm{~N}$ & 3 & SE & 1.39 & 0.43 & 0.52 & 0.001 & 0.44 & 0.28 & 0.20 & 3.8 \\
\hline & & & & Max & 17.60 & 12.40 & 19.40 & 0.078 & 15.6 & 9.70 & 7.20 & 187.0 \\
\hline & & & & Mean & 2.93 & 0.79 & 25.97 & 0.050 & 1.1 & 1.77 & 5.50 & 225.0 \\
\hline ERM2.5 & 2010 & Y & 3 & SE & 0.42 & 0.05 & 1.66 & 0.002 & 0.07 & 0.09 & 0.35 & 3.5 \\
\hline & & & & Max & 3.40 & 0.86 & 29.00 & 0.053 & 1.2 & 1.90 & 5.90 & 229.0 \\
\hline & & & & Mean & 39.53 & $11.75^{2}$ & 24.03 & 0.128 & 12.9 & 8.95 & 6.40 & 157.3 \\
\hline ERM1.0 & 2009 & $\mathrm{~N}$ & 4 & SE & 3.91 & 1.35 & 0.88 & 0.006 & 0.65 & 0.54 & 0.04 & 7.7 \\
\hline & & & & Max & 48.20 & 13.10 & 25.20 & 0.140 & 13.9 & 10.10 & 6.50 & 179.0 \\
\hline & & & & Mean & 46.20 & 11.10 & 20.37 & 0.112 & 12.8 & 9.60 & 9.67 & 146.0 \\
\hline ERM1.0 & 2010 & $\mathrm{~N}$ & 3 & SE & 6.45 & 0.21 & 0.49 & 0.014 & 0.26 & 0.51 & 1.71 & 5.2 \\
\hline & & & & $\operatorname{Max}$ & 54.50 & 11.50 & 21.20 & 0.140 & 13.3 & 10.30 & 11.90 & 155.0 \\
\hline & & & & Mean & 21.25 & 6.75 & 28.10 & 0.090 & 7.3 & 6.55 & 5.90 & 209.5 \\
\hline ERM1.0 & 2009 & $Y$ & 2 & SE & 7.65 & 3.85 & 4.90 & 0.030 & 3.90 & 3.45 & 0.00 & 2.5 \\
\hline & & & & $\operatorname{Max}$ & 28.90 & 10.60 & 33.00 & 0.120 & 11.2 & 10.00 & 5.90 & 212.0 \\
\hline & & & & Mean & 31.47 & 2.53 & 36.63 & 0.045 & 2.9 & 5.83 & 8.00 & 183.7 \\
\hline ERM1.0 & 2010 & $Y$ & 3 & SE & 6.93 & 0.43 & 2.74 & 0.002 & 0.38 & 0.95 & 0.56 & 2.9 \\
\hline & & & & Max & 41.60 & 3.30 & 41.30 & 0.049 & 3.6 & 7.20 & 8.70 & 189.0 \\
\hline Clinch Riv & & & & & & & & & & & & \\
\hline & & & & Mean & 4.80 & 8.6 & 17.18 & 0.753 & 9.2 & 8.6 & 3.95 & 189.5 \\
\hline CRM6.0 & 2009 & $\mathrm{~N}$ & 4 & SE & 0.25 & 0.39 & 0.47 & 0.069 & 0.39 & 0.32 & 0.10 & 9.7 \\
\hline & & & & $\operatorname{Max}$ & 5.40 & 9.50 & 18.30 & 0.920 & 10.1 & 9.50 & 4.20 & 212.0 \\
\hline & & & & Mean & 4.97 & 9.37 & 18.93 & 1.037 & 9.9 & 9.50 & 4.47 & 184.0 \\
\hline CRM6.0 & 2010 & $\mathrm{~N}$ & 3 & SE & 0.15 & 0.27 & 0.32 & 0.117 & 0.25 & 0.17 & 0.13 & 8.5 \\
\hline & & & & Max & 5.20 & 9.90 & 19.30 & 1.200 & 10.4 & 9.80 & 4.60 & 197.0 \\
\hline & & Y & & Mean & 1.93 & 0.63 & 37.77 & 0.150 & 1.1 & 3.00 & 4.20 & 276.3 \\
\hline CRMI6.0 & 2010 & $Y$ & 3 & SE & 0.22 & 0.05 & 1.37 & 0.010 & 0.03 & 0.12 & 0.15 & 24.2 \\
\hline
\end{tabular}




\begin{tabular}{|c|c|c|c|c|c|c|c|c|c|c|c|c|}
\hline River/site & Year & Depurated $^{\top}$ & $\mathrm{N}$ & Statistic & As & $\mathrm{Cr}$ & $\mathrm{Cu}$ & $\mathrm{Pb}$ & $\mathrm{Hg}$ & $\mathrm{Ni}$ & Se & $\mathrm{Zn}$ \\
\hline & & & & Max & 2.20 & 0.70 & 40.40 & 0.160 & 1.2 & 3.20 & 4.50 & 324.0 \\
\hline & & & & Mean & 14.57 & 11.30 & 20.30 & 0.273 & 12.1 & 8.57 & 7.03 & 177.0 \\
\hline \multirow[t]{2}{*}{ CRM3.5 } & 2010 & $\mathrm{~N}$ & 3 & SE & 0.92 & 0.31 & 0.51 & 0.013 & 0.27 & 0.24 & 0.23 & 2.9 \\
\hline & & & & Max & 16.40 & 11.70 & 21.00 & 0.300 & 12.4 & 8.90 & 7.40 & 182.0 \\
\hline & & & & Mean & 4.50 & 1.77 & 31.80 & 0.090 & 2.1 & 2.97 & 7.90 & 201.3 \\
\hline \multirow[t]{2}{*}{ CRM3.5 } & 2010 & $Y$ & 3 & SE & 0.46 & 0.30 & 1.65 & 0.004 & 0.27 & 0.24 & 0.21 & 2.3 \\
\hline & & & & $\operatorname{Max}$ & 5.30 & 2.20 & 35.10 & 0.099 & 2.5 & 3.30 & 8.30 & 205.0 \\
\hline \multirow{3}{*}{ CRM1.5 } & & & & Mean & 13.83 & 10.38 & 30.10 & 0.368 & 11.8 & 9.05 & 5.38 & 218.5 \\
\hline & 2009 & $\mathrm{~N}$ & 4 & SE & 0.72 & 0.38 & 1.44 & 0.010 & 0.41 & 0.37 & 0.03 & 11.8 \\
\hline & & & & Max & 15.20 & 11.50 & 33.00 & 0.390 & 12.9 & 10.10 & 5.40 & 249.0 \\
\hline \multirow{3}{*}{ CRM1.5 } & & & & Mean & 12.73 & 9.90 & 21.00 & 0.273 & 10.9 & 7.83 & 6.43 & 185.7 \\
\hline & 2010 & $\mathrm{~N}$ & 3 & SE & 1.04 & 0.96 & 1.39 & 0.009 & 0.94 & 0.73 & 0.17 & 5.6 \\
\hline & & & & $\operatorname{Max}$ & 14.60 & 11.80 & 23.40 & 0.290 & 12.7 & 9.20 & 6.60 & 194.0 \\
\hline \multirow{3}{*}{ CRM1.5 } & & & & Mean & 4.50 & 2.35 & 39.20 & $<0.086$ & 3.0 & 3.85 & 4.75 & 319.0 \\
\hline & 2009 & $Y$ & 2 & SE & 0.60 & 0.25 & 0.10 & . & 0.10 & 0.05 & 0.35 & 60.0 \\
\hline & & & & Max & 5.10 & 2.60 & 39. & . & 3.1 & 3.90 & 5.10 & 379.0 \\
\hline \multirow{3}{*}{ CRM1.5 } & & & & Mean & 3.73 & 1.08 & 33.03 & 0.081 & 1.5 & 2.67 & 7.13 & 201.3 \\
\hline & 2010 & $Y$ & 3 & SE & 0.87 & 0.16 & 0.5 & 0.006 & 0.17 & 0.23 & 0.15 & 11.9 \\
\hline & & & & Max & 4.70 & 1.40 & & 0.087 & 1.8 & 3.10 & 7.40 & 224.0 \\
\hline \multicolumn{13}{|c|}{ Little Emory River } \\
\hline \multirow{3}{*}{ LERM1.0 } & & & & Mean & 4.30 & 8.63 & 13.33 & 0.084 & 11.1 & 6.73 & 3.30 & 231.0 \\
\hline & 2009 & $\mathrm{~N}$ & 3 & SE & 0.17 & 0.34 & 0.19 & 0.003 & 0.23 & 0.09 & 0.06 & 5.0 \\
\hline & & & & Max & 4.60 & 9.30 & 13.70 & 0.089 & 11.5 & 6.90 & 3.40 & 241.0 \\
\hline \multirow{3}{*}{ LERM1.0 } & & & & Mean & 3.90 & 4.90 & 11.60 & 0.059 & 7.1 & 4.77 & 3.93 & 279.0 \\
\hline & 2010 & $\mathrm{~N}$ & 3 & SE & 0.30 & 0.21 & 0.61 & 0.004 & 0.20 & 0.15 & 0.15 & 30.7 \\
\hline & & & & Max & & 5.20 & & 0.066 & 7.4 & 5.00 & 4.20 & 316.0 \\
\hline \multicolumn{13}{|c|}{ Tennessee River } \\
\hline \multirow{3}{*}{ TRM571.9 } & & & & Mean & 5.30 & 8.57 & 12.87 & 0.055 & 6.6 & 9.77 & 4.40 & 206.3 \\
\hline & 2010 & $\mathrm{~N}$ & 3 & SE & 0.45 & 0.54 & 0.52 & 0.002 & 0.44 & 0.73 & 0.21 & 5.2 \\
\hline & & & & Max & 5.80 & 9.20 & 13.80 & 0.057 & 7.1 & 10.50 & 4.70 & 212.0 \\
\hline \multirow{3}{*}{ TRM571.9 } & & & & Mean & 1.43 & 1.53 & 26.80 & 0.037 & 1.4 & 4.30 & 2.20 & 322.7 \\
\hline & 2010 & $\mathrm{Y}$ & 3 & SE & 0.20 & 0.30 & 0.98 & 0.003 & 0.21 & 0.3 & 0.10 & 15.7 \\
\hline & & & & Max & 1.80 & 2.10 & 28.20 & 0.040 & 1.8 & 4.70 & 2.30 & 354.0 \\
\hline \multirow{3}{*}{ TRM566.3 } & & & & Mean & 9.63 & 11.17 & 20.77 & 0.123 & 9.8 & 9.33 & 5.80 & 220.7 \\
\hline & 2010 & $\mathrm{~N}$ & 3 & SE & 0.39 & 0.47 & 0.35 & 0.007 & 0.42 & 0.38 & 0.12 & 14.2 \\
\hline & & & & Max & 10.40 & 12.10 & 21.40 & 0.130 & 10.6 & 10.10 & 6.00 & 240.0 \\
\hline \multirow{3}{*}{ TRM566.3 } & & & & Mean & 1.83 & 0.98 & 29.90 & 0.041 & 1.1 & 2.70 & 3.63 & 315.0 \\
\hline & 2010 & Y & 3 & SE & 0.19 & 0.17 & 1.47 & 0.003 & 0.14 & 0.2 & 0.18 & 22.5 \\
\hline & & & & $\operatorname{Max}$ & 2.20 & 1.20 & 32.70 & 0.045 & 1.3 & 2.90 & 3.90 & 353.0 \\
\hline \multirow{3}{*}{ TRM560.8 } & & & & Mean & 10.30 & 11.07 & 20.90 & 0.160 & 9.9 & 9.50 & 5.47 & 251.0 \\
\hline & 2010 & $\mathrm{~N}$ & 3 & SE & 0.51 & 0.90 & 0.61 & 0.010 & 0.75 & 0.75 & 0.30 & 21.7 \\
\hline & & & & Max & 11.00 & 12.20 & 21.70 & 0.170 & 10.8 & 10.40 & 5.90 & 292.0 \\
\hline
\end{tabular}

1" $\mathrm{N}$ " = Nymphs were not depurated prior to analysis; "Y" = nymphs were depurated for $48 \mathrm{hr}$ prior to analysis.

${ }^{2}$ Only 2 replicates had concentrations above the method detection limit; descriptive statistics based on only those 2 replicates. 
Table B.2. Mean, standard error of the mean (SE), and maximum (Max) concentrations ( $\mu \mathrm{g} / \mathrm{g}$ dry weight) of elements (total) of potential ecological concern (excluding those of bioaccumulative concern in Table 4) in mayfly nymphs (Hexagenia bilineata) from the Emory

River, Clinch River, and Tennessee River, 2009 and 2010. $\mathrm{N}=$ Number of replicate samples. Values for means proceeded by a " $<$ " symbol indicate that concentrations for all replicates were below the method detection limit (MDL); the numeral after the "<" symbol is the highest MDL report among all replicates from a sample. Observations with mean and maximum concentrations but no SE indicate that the concentration was

\begin{tabular}{|c|c|c|c|c|c|c|c|c|c|c|c|c|c|c|c|c|c|}
\hline River/site & Year & Depurated $^{1}$ & $\mathrm{~N}$ & Statistic & $\mathrm{Al}$ & $\mathrm{Sb}$ & $\mathrm{Ba}$ & $\mathrm{Be}$ & $\mathrm{B}$ & $\mathrm{Cd}$ & Co & $\mathrm{Mn}$ & Mo & $\mathrm{Ag}$ & $\mathrm{Sr}$ & $\mathrm{TI}$ & $\mathrm{V}$ \\
\hline \multicolumn{18}{|c|}{ Emory River } \\
\hline & & & & Mean & 4285.0 & 0.043 & 40.2 & 0.220 & 3.78 & 0.61 & 4.53 & 449.3 & 0.558 & $<0.048$ & 5.23 & 0.051 & 7.60 \\
\hline \multirow[t]{3}{*}{ ERM6.0 } & 2009 & $\mathrm{~N}$ & 4 & SE & 400.5 & 0.002 & 2.7 & 0.027 & 0.68 & 0.13 & 0.19 & 10.6 & 0.017 & . & 0.38 & 0.005 & 0.85 \\
\hline & & & & Max & 4960.0 & 0.046 & 43.7 & 0.280 & 5.80 & 1.00 & 4.90 & 464.0 & 0.590 & & 5.70 & 0.064 & 9.10 \\
\hline & & & & Mean & 5546.7 & 0.067 & 49.5 & 0.263 & 3.07 & 0.47 & 4.70 & 416.3 & 0.510 & 0.033 & 6.30 & 0.068 & 8.23 \\
\hline \multirow[t]{3}{*}{ ERM6.0 } & 2010 & $\mathrm{~N}$ & 3 & SE & 613.5 & 0.005 & 3.5 & 0.022 & 0.47 & 0.08 & 0.31 & 19.4 & 0.010 & 0.002 & 0.26 & 0.005 & 0.80 \\
\hline & & & & Max & 6380.0 & 0.073 & 55.1 & 0.290 & 4.00 & 0.61 & 5.10 & 441.0 & 0.530 & 0.038 & 6.70 & 0.073 & 9.40 \\
\hline & & & & Mean & 857.0 & 0.024 & 11.8 & 0.072 & 2.03 & 0.75 & 1.80 & 146.0 & 0.537 & 0.048 & 3.40 & $<0.021$ & 1.35 \\
\hline \multirow[t]{2}{*}{ ERM6.0 } & 2010 & $\mathrm{Y}$ & 3 & SE & 267.0 & & 2.3 & & 0.09 & 0.14 & 0.23 & 34.5 & 0.009 & 0.003 & 0.35 & . & 0.38 \\
\hline & & & & Max & 1380.0 & 0.024 & 16.4 & 0.072 & 2.20 & 0.91 & 2.20 & 214.0 & 0.550 & 0.051 & 3.80 & . & 2.10 \\
\hline \multirow{3}{*}{ ERM4.0 } & & & & Mean & 5666.7 & 0.117 & 57.2 & 0.433 & 3.00 & 0.20 & 5.47 & 301.7 & 0.743 & 0.040 & 12.17 & 0.113 & 9.97 \\
\hline & 2010 & $\mathrm{~N}$ & 3 & $\begin{array}{l}\text { SE } \\
\text { Max }\end{array}$ & $\begin{array}{c}336.7 \\
6340.0\end{array}$ & $\begin{array}{l}0.003 \\
0.120\end{array}$ & $\begin{array}{c}2.9 \\
63.0\end{array}$ & $\begin{array}{l}0.033 \\
0.500\end{array}$ & $\begin{array}{l}0.15 \\
3.30\end{array}$ & $\begin{array}{l}0.02 \\
0.25\end{array}$ & $\begin{array}{l}0.32 \\
6.10\end{array}$ & $\begin{array}{c}52.7 \\
407.0\end{array}$ & $\begin{array}{l}0.017 \\
0.760\end{array}$ & $\begin{array}{l}0.004 \\
0.047\end{array}$ & $\begin{array}{c}0.27 \\
12.70\end{array}$ & $\begin{array}{l}0.003 \\
0.120\end{array}$ & $\begin{array}{c}0.37 \\
10.70 \\
\end{array}$ \\
\hline & & & & Mean & 1061.7 & 0.036 & 20.3 & 0.049 & 1.90 & 0.10 & 1.53 & 157.5 & 0.870 & 0.038 & 7.27 & $<0.028$ & 2.30 \\
\hline \multirow[t]{3}{*}{ ERM4.0 } & 2010 & $\mathrm{Y}$ & 3 & SE & 210.7 & 0.004 & 1.7 & & & 0.02 & 0.07 & 44.1 & 0.118 & 0.002 & 0.92 & . & 0.31 \\
\hline & & & & Max & 1400.0 & 0.040 & 23.4 & 0.049 & 1.90 & 0.14 & 1.60 & 244.0 & 1.100 & 0.041 & 8.60 & . & 2.70 \\
\hline & & & & Mean & 7210.0 & 0.212 & 71.6 & 0.650 & 6.48 & 0.57 & 7.34 & 466.0 & 1.398 & 0.044 & 22.78 & 0.200 & 16.40 \\
\hline \multirow[t]{2}{*}{ ERM2.5 } & 2009 & $\mathrm{~N}$ & 5 & SE & 643.7 & 0.018 & 6.2 & 0.073 & 1.18 & 0.19 & 0.38 & 64.9 & 0.124 & 0.002 & 2.03 & 0.021 & 1.58 \\
\hline & & & & Max & 9180.0 & 0.280 & 91.5 & 0.870 & 11.10 & 1.20 & 8.70 & 710.0 & 1.700 & 0.047 & 28.40 & 0.260 & 21.70 \\
\hline \multirow{4}{*}{ ERM2.5 } & & & & Mean & 9693.3 & 0.213 & 89.6 & 0.797 & 5.20 & 0.58 & 9.23 & 490.7 & 1.267 & 0.043 & 23.63 & 0.237 & 18.57 \\
\hline & 2010 & $\mathrm{~N}$ & 3 & SE & 361.3 & 0.007 & 2.4 & 0.043 & 0.20 & 0.07 & 0.28 & 19.4 & 0.067 & 0.006 & 0.84 & 0.015 & 0.70 \\
\hline & & & & $\operatorname{Max}$ & 10300.0 & 0.220 & 93.0 & 0.880 & 5.40 & 0.68 & 9.80 & 520.0 & 1.400 & 0.048 & 25.00 & 0.260 & 19.70 \\
\hline & & & & Mean & 480.0 & 0.037 & 20.8 & 0.048 & 1.75 & 0.69 & 1.27 & 120.7 & 1.133 & 0.035 & 10.00 & 0.032 & 1.40 \\
\hline \multirow[t]{3}{*}{ ERM2.5 } & 2010 & $\mathrm{Y}$ & 3 & SE & 29.7 & 0.002 & 0.5 & & 0.51 & 0.13 & 0.22 & 6.9 & 0.033 & 0.001 & 0.20 & 0.007 & 0.06 \\
\hline & & & & Max & 525.0 & 0.040 & 21.7 & 0.048 & 2.70 & 0.96 & 1.70 & 129.0 & 1.200 & 0.037 & 10.40 & 0.043 & 1.50 \\
\hline & & & & Mean & 8635.0 & 0.470 & 125.8 & 1.083 & 11.78 & 0.69 & 7.23 & 410.8 & 3.725 & 0.052 & 53.95 & 0.530 & 25.90 \\
\hline \multirow[t]{3}{*}{ ERM1.0 } & 2009 & $\mathrm{~N}$ & 4 & SE & 394.9 & 0.038 & 9.3 & 0.087 & 1.48 & 0.15 & 0.28 & 15.0 & 0.193 & 0.006 & 5.26 & 0.066 & 1.90 \\
\hline & & & & Max & 9380.0 & 0.580 & 144.0 & 1.200 & 14.30 & 0.96 & 7.60 & 445.0 & 4.100 & 0.062 & 63.20 & 0.660 & 28.80 \\
\hline & & & & Mean & 7976.7 & 0.380 & 121.1 & 0.877 & 7.03 & 0.63 & 7.67 & 507.0 & 2.200 & 0.044 & 45.07 & 0.433 & 21.53 \\
\hline \multirow[t]{3}{*}{ ERM1.0 } & 2010 & $\mathrm{~N}$ & 3 & SE & 295.5 & 0.060 & 14.9 & 0.056 & 0.90 & 0.25 & 0.22 & 15.4 & 0.379 & 0.004 & 8.83 & 0.103 & 1.22 \\
\hline & & & & Max & 8540.0 & 0.450 & 138.0 & 0.960 & 8.50 & 1.10 & 8.10 & 535.0 & 2.900 & 0.047 & 55.40 & 0.560 & 22.80 \\
\hline & & & & Mean & 4610.0 & 0.390 & 79.5 & 0.610 & 7.65 & 0.87 & 4.45 & 269.5 & 4.300 & 0.031 & 36.10 & 0.310 & 15.55 \\
\hline \multirow[t]{2}{*}{ ERM1.0 } & 2009 & $\mathrm{Y}$ & 2 & SE & 2860.0 & 0.180 & 44.6 & 0.390 & 2.75 & 0.08 & 1.95 & 85.5 & 0.400 & 0.018 & 19.10 & 0.170 & 9.15 \\
\hline & & & & Max & 7470.0 & 0.570 & 124.0 & 1.000 & 10.40 & 0.94 & 6.40 & 355.0 & 4.700 & 0.048 & 55.20 & 0.480 & 24.70 \\
\hline
\end{tabular}




\begin{tabular}{|c|c|c|c|c|c|c|c|c|c|c|c|c|c|c|c|c|c|}
\hline River/site & Year & Depurated $^{1}$ & $\mathrm{~N}$ & Statistic & $\mathrm{Al}$ & $\mathrm{Sb}$ & $\mathrm{Ba}$ & $\mathrm{Be}$ & $\mathrm{B}$ & $\mathrm{Cd}$ & Co & $\mathrm{Mn}$ & Mo & $\mathrm{Ag}$ & $\mathrm{Sr}$ & $\mathrm{TI}$ & $\mathrm{V}$ \\
\hline & & & & Mean & 1660.0 & 0.190 & 39.1 & 0.193 & 3.37 & 0.49 & 1.90 & 193.0 & 2.867 & 0.031 & 17.70 & 0.101 & 5.93 \\
\hline \multirow[t]{2}{*}{ ERM1.0 } & 2010 & $\mathrm{Y}$ & 3 & SE & 266.3 & 0.031 & 2.6 & 0.032 & 0.49 & 0.14 & 0.26 & 11.8 & 0.240 & 0.005 & 0.64 & 0.027 & 1.05 \\
\hline & & & & Max & 2140.0 & 0.230 & 42.7 & 0.250 & 4.00 & 0.73 & 2.40 & 216.0 & 3.200 & 0.039 & 18.70 & 0.150 & 7.40 \\
\hline \multicolumn{18}{|c|}{$\underline{\text { Clinch River }}$} \\
\hline \multirow{4}{*}{ CRM6.0 } & & & & Mean & 6747.5 & 0.068 & 51.3 & 0.330 & 5.98 & 1.02 & 5.15 & 932.8 & 0.758 & 0.053 & 9.65 & 0.108 & 11.50 \\
\hline & 2009 & $\mathrm{~N}$ & 4 & SE & 211.8 & 0.002 & 2.4 & 0.025 & 0.44 & 0.08 & 0.17 & 24.8 & 0.038 & 0.004 & 0.53 & 0.007 & 0.51 \\
\hline & & & & Max & 7290.0 & 0.074 & 57.5 & 0.380 & 7.30 & 1.20 & 5.50 & 1000.0 & 0.860 & 0.062 & 11.00 & 0.120 & 12.50 \\
\hline & & & & Mean & 7150.0 & 0.094 & 57.7 & 0.343 & 6.70 & 0.87 & 5.97 & 969.3 & 0.747 & 0.071 & 9.17 & 0.105 & 11.33 \\
\hline \multirow[t]{3}{*}{ CRM6.0 } & 2010 & $\mathrm{~N}$ & 3 & SE & 293.7 & 0.002 & 1.1 & 0.009 & 0.64 & 0.07 & 0.15 & 39.1 & 0.038 & 0.012 & 0.15 & 0.005 & 0.30 \\
\hline & & & & Max & 7620.0 & 0.098 & 59.8 & 0.360 & 7.90 & 0.95 & 6.20 & 1040.0 & 0.790 & 0.095 & 9.40 & 0.110 & 11.90 \\
\hline & & & & Mean & 316.0 & $<0.021$ & 6.4 & $<0.043$ & 4.83 & 1.39 & 1.19 & 113.3 & 0.907 & 0.031 & 4.77 & $<0.02$ & 0.70 \\
\hline \multirow[t]{3}{*}{ CRM6.0 } & 2010 & $Y$ & 3 & SE & 33.5 & . & 0.2 & . & 1.20 & 0.36 & 0.26 & 13.4 & 0.009 & 0.003 & 0.39 & . & 0.07 \\
\hline & & & & Max & 374.0 & . & 6.8 & . & 6.70 & 2.10 & 1.70 & 138.0 & 0.920 & 0.037 & 5.30 & . & 0.82 \\
\hline & & & & Mean & 8870.0 & 0.240 & 94.4 & 0.740 & 6.80 & 0.95 & 7.33 & 762.0 & 1.567 & 0.062 & 28.57 & 0.300 & 18.17 \\
\hline \multirow[t]{3}{*}{ CRM3.5 } & 2010 & $\mathrm{~N}$ & 3 & SE & 215.9 & 0.006 & 1.6 & 0.015 & 0.31 & 0.10 & 0.20 & 10.8 & 0.033 & 0.001 & 1.50 & 0.006 & 0.55 \\
\hline & & & & Max & 9120.0 & 0.250 & 96.9 & 0.770 & 7.20 & 1.10 & 7.70 & 782.0 & 1.600 & 0.064 & 31.10 & 0.310 & 18.90 \\
\hline & & & & Mean & 1132.3 & 0.064 & 22.3 & 0.103 & 3.33 & 1.23 & 1.60 & 200.7 & 1.533 & 0.034 & 11.10 & 0.052 & 2.90 \\
\hline \multirow[t]{3}{*}{ CRM3.5 } & 2010 & $Y$ & 3 & SE & 209.5 & 0.009 & 1.8 & 0.023 & 0.58 & 0.09 & 0.12 & 8.4 & 0.067 & 0.008 & 1.05 & 0.009 & 0.47 \\
\hline & & & & Max & 1450.0 & 0.075 & 24.5 & 0.130 & 4.10 & 1.40 & 1.80 & 215.0 & 1.600 & 0.050 & 12.30 & 0.061 & 3.60 \\
\hline & & & & Mean & 7920.0 & 0.225 & 83.3 & 0.740 & 7.45 & 1.85 & 7.00 & 1092.5 & 1.725 & 0.048 & 33.08 & 0.308 & 19.43 \\
\hline \multirow[t]{3}{*}{ CRM1.5 } & 2009 & $\mathrm{~N}$ & 4 & SE & 297.2 & 0.006 & 2.9 & 0.045 & 0.36 & 0.31 & 0.20 & 37.1 & 0.095 & 0.001 & 1.42 & 0.022 & 0.75 \\
\hline & & & & Max & 8790.0 & 0.240 & 91.5 & 0.870 & 8.40 & 2.60 & 7.60 & 1160.0 & 2.000 & 0.050 & 36.90 & 0.370 & 21.60 \\
\hline & & & & Mean & 7720.0 & 0.220 & 84.7 & 0.647 & 7.67 & 1.53 & 6.67 & 861.0 & 1.467 & 0.059 & 25.53 & 0.257 & 15.93 \\
\hline \multirow[t]{3}{*}{ CRM1.5 } & 2010 & $\mathrm{~N}$ & 3 & SE & 683.0 & 0.025 & 7.6 & 0.073 & 0.71 & 0.30 & 0.58 & 66.9 & 0.133 & 0.004 & 2.73 & 0.038 & 1.72 \\
\hline & & & & Max & 9080.0 & 0.270 & 99.8 & 0.790 & 9.00 & 2.10 & 7.70 & 959.0 & 1.600 & 0.067 & 31.00 & 0.330 & 19.30 \\
\hline & & & & Mean & 1550.0 & 0.105 & 22.7 & 0.140 & 3.30 & 2.50 & 2.50 & 362.5 & 2.250 & 0.022 & 10.00 & 0.111 & 4.45 \\
\hline \multirow[t]{3}{*}{ CRM1.5 } & 2009 & $Y$ & 2 & SE & 30.0 & 0.005 & 0.9 & 0.010 & 0.10 & 1.20 & 0.10 & 89.5 & 0.650 & 0.000 & 0.30 & 0.020 & 0.15 \\
\hline & & & & Max & 1580.0 & 0.110 & 23.5 & 0.150 & 3.40 & 3.70 & 2.60 & 452.0 & 2.900 & 0.022 & 10.30 & 0.130 & 4.60 \\
\hline & & & & Mean & 663.3 & $0.047^{2}$ & 16.6 & 0.067 & 4.00 & 1.09 & 1.23 & 174.3 & 1.700 & 0.032 & 8.67 & 0.036 & 1.77 \\
\hline \multirow[t]{2}{*}{ CRM1.5 } & 2010 & Y & 3 & SE & 134.6 & 0.005 & 2.5 & 0.016 & 0.78 & 0.36 & 0.09 & 22.2 & 0.200 & 0.002 & 0.71 & 0.003 & 0.29 \\
\hline & & & & Max & 914.0 & 0.052 & 20.7 & 0.082 & 5.40 & 1.80 & 1.40 & 213.0 & 1.900 & 0.036 & 9.70 & 0.039 & 2.30 \\
\hline \multicolumn{18}{|c|}{ Little Emory River } \\
\hline & & & & Mean & 7776.7 & 0.140 & 71.1 & 0.347 & $4.70^{2}$ & 1.97 & 7.70 & 1256.7 & 0.710 & 0.157 & 7.60 & $<0.014$ & 12.20 \\
\hline \multirow[t]{3}{*}{ LERM1.0 } & 2009 & $\mathrm{~N}$ & 3 & SE & 143.3 & 0.010 & 0.8 & 0.009 & 0.70 & 0.07 & 0.06 & 23.3 & 0.012 & 0.003 & 0.23 & . & 0.21 \\
\hline & & & & Max & 7980.0 & 0.150 & 72.4 & 0.360 & 5.40 & 2.10 & 7.80 & 1300.0 & 0.730 & 0.160 & 8.00 & . & 12.50 \\
\hline & & & & Mean & 4336.7 & 0.080 & 52.0 & 0.207 & 3.27 & 1.77 & 6.50 & 1306.7 & 0.717 & 0.147 & 4.97 & 0.053 & 7.10 \\
\hline \multirow[t]{2}{*}{ LERM1.0 } & 2010 & $\mathrm{~N}$ & 3 & SE & 133.8 & 0.003 & 3.3 & 0.012 & 0.12 & 0.44 & 0.35 & 68.4 & 0.003 & 0.007 & 0.29 & 0.000 & 0.21 \\
\hline & & & & Max & 4550.0 & 0.085 & 58.6 & 0.230 & 3.50 & 2.40 & 7.20 & 1380.0 & 0.720 & 0.160 & 5.50 & 0.053 & 7.40 \\
\hline
\end{tabular}




\begin{tabular}{|c|c|c|c|c|c|c|c|c|c|c|c|c|c|c|c|c|c|}
\hline River/site & Year & Depurated $^{1}$ & $\mathrm{~N}$ & Statistic & $\mathrm{Al}$ & $\mathrm{Sb}$ & $\mathrm{Ba}$ & $\mathrm{Be}$ & $\mathrm{B}$ & $\mathrm{Cd}$ & Co & $\mathrm{Mn}$ & Mo & $\mathrm{Ag}$ & $\mathrm{Sr}$ & $\mathrm{TI}$ & $\mathrm{V}$ \\
\hline \multicolumn{18}{|c|}{ Tennessee River } \\
\hline & & & & Mean & 7676.7 & 0.088 & 68.1 & 0.327 & 2.83 & 1.17 & 4.93 & 1147.0 & 0.527 & 0.062 & 8.23 & 0.098 & 12.33 \\
\hline \multirow[t]{3}{*}{ TRM571.9 } & 2010 & $\mathrm{~N}$ & 3 & SE & 495.6 & 0.005 & 5.0 & 0.019 & 0.33 & 0.07 & 0.29 & 203.2 & 0.017 & 0.004 & 0.52 & 0.008 & 0.82 \\
\hline & & & & Max & 8350.0 & 0.094 & 73.7 & 0.350 & 3.30 & 1.30 & 5.40 & 1540.0 & 0.560 & 0.069 & 8.80 & 0.110 & 13.30 \\
\hline & & & & Mean & 1169.0 & 0.030 & 12.0 & 0.069 & 1.93 & 1.77 & 1.57 & 218.3 & 0.523 & 0.047 & 4.37 & 0.027 & 1.90 \\
\hline \multirow[t]{3}{*}{ TRM571.9 } & 2010 & $Y$ & 3 & SE & 289.1 & 0.003 & 1.8 & . & 0.24 & 0.18 & 0.13 & 52.0 & 0.019 & 0.002 & 0.24 & . & 0.42 \\
\hline & & & & Max & 1730.0 & 0.036 & 15.6 & 0.069 & 2.40 & 2.10 & 1.70 & 321.0 & 0.560 & 0.051 & 4.70 & 0.027 & 2.70 \\
\hline & & & & Mean & 9810.0 & 0.170 & 81.2 & 0.510 & 6.97 & 1.39 & 6.63 & 1276.3 & 1.093 & 0.039 & 20.70 & 0.167 & 16.97 \\
\hline \multirow[t]{3}{*}{ TRM566.3 } & 2010 & $\mathrm{~N}$ & 3 & SE & 449.9 & 0.006 & 4.3 & 0.059 & 0.23 & 0.22 & 0.28 & 150.0 & 0.121 & . & 0.87 & 0.012 & 0.72 \\
\hline & & & & Max & 10700.0 & 0.180 & 87.6 & 0.620 & 7.40 & 1.70 & 7.20 & 1460.0 & 1.300 & 0.039 & 22.40 & 0.190 & 18.40 \\
\hline & & & & Mean & 560.7 & 0.024 & 8.6 & $<0.047$ & 3.33 & 2.33 & 1.50 & 106.1 & 0.740 & 0.027 & 4.90 & $0.026^{2}$ & 1.14 \\
\hline \multirow[t]{3}{*}{ TRM566.3 } & 2010 & $Y$ & 3 & SE & 135.6 & 0.002 & 1.0 & . & 0.68 & 0.44 & 0.06 & 23.8 & 0.066 & 0.002 & 0.21 & 0.007 & 0.23 \\
\hline & & & & Max & 780.0 & 0.029 & 10.4 & . & 4.70 & 3.00 & 1.60 & 153.0 & 0.820 & 0.030 & 5.20 & 0.032 & 1.50 \\
\hline & & & & Mean & 9786.7 & 0.157 & 79.0 & $0.553^{2}$ & 5.45 & 1.10 & 7.43 & 1373.3 & 0.943 & 0.061 & 19.53 & 0.147 & 16.60 \\
\hline \multirow[t]{2}{*}{ TRM560.8 } & 2010 & $\mathrm{~N}$ & 3 & SE & 875.3 & 0.003 & 6.5 & 0.064 & 0.15 & 0.26 & 0.37 & 93.9 & 0.013 & 0.010 & 1.13 & 0.009 & 1.32 \\
\hline & & & & Max & 10900.0 & 0.160 & 86.2 & 0.660 & 5.60 & 1.60 & 7.80 & 1500.0 & 0.970 & 0.077 & 20.90 & 0.160 & 18.30 \\
\hline
\end{tabular}

1"N" = Nymphs were not depurated prior to analysis; "Y" = nymphs were depurated for $48 \mathrm{hr}$ prior to analysis.

${ }^{2}$ Only 2 replicates had concentrations above the method detection limit; descriptive statistics based on only those 2 replicates. 
Table B.3. Mean, standard error of the mean (SE), and maximum (Max) concentrations ( $\mu \mathrm{g} / \mathrm{g}$ dry weight) of major cations and iron (total) in mayfly nymphs (Hexagenia bilineata) from the Emory River, Clinch River, and Tennessee River, 2009 and 2010. $\mathrm{N}=$ Number of replicate samples. Values for means proceeded by a " $<$ " symbol indicate that concentrations for all replicates were below the method detection limit (MDL); the numeral after the "<" symbol is the highest MDL report among all replicates from a sample. Observations with mean and maximum concentrations but no SE indicate that the concentration was below the MDL in all but one replicate.

\begin{tabular}{|c|c|c|c|c|c|c|c|c|c|}
\hline River/site & Year & Depurated $^{1}$ & $\mathrm{~N}$ & Statistic & $\mathrm{Ca}$ & $\mathrm{Fe}$ & $\mathrm{Mg}$ & $\mathrm{K}$ & $\mathrm{Na}$ \\
\hline \multicolumn{10}{|l|}{ Emory River } \\
\hline & & & & Mean & 1695.0 & 6112.5 & 1257.5 & 7115.0 & 5987.5 \\
\hline \multirow[t]{3}{*}{ ERM6.0 } & 2009 & $\mathrm{~N}$ & 4 & SE & 56.9 & 397.5 & 25.3 & 128.9 & 205.4 \\
\hline & & & & Max & 1830.0 & 6890.0 & 1320.0 & 7430.0 & 6410.0 \\
\hline & & & & Mean & 1630.0 & 7410.0 & 1160.0 & 5730.0 & 4476.7 \\
\hline \multirow[t]{3}{*}{ ERM6.0 } & 2010 & $\mathrm{~N}$ & 3 & SE & 46.2 & 692.0 & 72.3 & 116.8 & 222.6 \\
\hline & & & & Max & 1710.0 & 8430.0 & 1280.0 & 5960.0 & 4770.0 \\
\hline & & & & Mean & 1600.0 & 1296.7 & 1100.0 & 8583.3 & 4126.7 \\
\hline \multirow[t]{3}{*}{ ERM6.0 } & 2010 & $\mathrm{Y}$ & 3 & SE & 89.6 & 364.5 & 20.0 & 177.4 & 162.7 \\
\hline & & & & Max & 1750.0 & 2010.0 & 1140.0 & 8910.0 & 4350.0 \\
\hline & & & & Mean & 1890.0 & 7670.0 & 1306.7 & 6640.0 & 5120.0 \\
\hline \multirow[t]{3}{*}{ ERM4.0 } & 2010 & $\mathrm{~N}$ & 3 & SE & 20.8 & 775.4 & 20.3 & 282.9 & 437.1 \\
\hline & & & & Max & 1930.0 & 9220.0 & 1340.0 & 7190.0 & 5960.0 \\
\hline & & & & Mean & 1893.3 & 2296.7 & 1250.0 & 9446.7 & 6043.3 \\
\hline \multirow[t]{3}{*}{ ERM4.0 } & 2010 & Y & 3 & SE & 97.0 & 154.3 & 66.6 & 251.0 & 66.7 \\
\hline & & & & $\operatorname{Max}$ & 2040.0 & 2480.0 & 1340.0 & 9840.0 & 6110.0 \\
\hline & & & & Mean & 2276.0 & 8266.0 & 1478.0 & 7196.0 & 5288.0 \\
\hline \multirow[t]{3}{*}{ ERM2.5 } & 2009 & $\mathrm{~N}$ & 5 & SE & 101.8 & 720.7 & 39.9 & 320.6 & 426.5 \\
\hline & & & & Max & 2600.0 & 10300.0 & 1590.0 & 8120.0 & 6730.0 \\
\hline & & & & Mean & 2216.7 & 10966.7 & 1553.3 & $<10200$ & 6210.0 \\
\hline \multirow[t]{3}{*}{ ERM2.5 } & 2010 & $\mathrm{~N}$ & 3 & SE & 12.0 & 384.4 & 32.8 & & 372.2 \\
\hline & & & & Max & 2240.0 & 11400.0 & 1600.0 & & 6950.0 \\
\hline & & & & Mean & 2126.7 & 868.3 & 1196.7 & 9333.3 & 6446.7 \\
\hline \multirow[t]{3}{*}{ ERM2.5 } & 2010 & Y & 3 & SE & 48.4 & 72.2 & 14.5 & 154.5 & 206.3 \\
\hline & & & & Max & 2180.0 & 968.0 & 1220.0 & 9630.0 & 6850.0 \\
\hline & & & & Mean & 3070.0 & 8575.0 & 1510.0 & 6610.0 & 4537.5 \\
\hline \multirow[t]{3}{*}{ ERM1.0 } & 2009 & $\mathrm{~N}$ & 4 & SE & 121.7 & 412.6 & 24.5 & 241.2 & 245.5 \\
\hline & & & & $\operatorname{Max}$ & 3290.0 & 9460.0 & 1570.0 & 6990.0 & 4930.0 \\
\hline & & & & Mean & 2470.0 & 9710.0 & 1276.7 & 6325.0 & 4516.7 \\
\hline \multirow[t]{2}{*}{ ERM1.0 } & 2010 & $\mathrm{~N}$ & 3 & SE & 91.7 & 945.0 & 52.1 & 105.0 & 148.4 \\
\hline & & & & Max & 2650.0 & 11600.0 & 1370.0 & 6430.0 & 4670.0 \\
\hline \multirow{3}{*}{ ERM1.0 } & & & & Mean & 2550.0 & 4740.0 & 1250.0 & 6220.0 & 3960.0 \\
\hline & 2009 & Y & 2 & SE & 520.0 & 2760.0 & 140.0 & 480.0 & 750.0 \\
\hline & & & & Max & 3070.0 & 7500.0 & 1390.0 & 6700.0 & 4710.0 \\
\hline & & & & Mean & 2153.3 & 2893.3 & 1156.7 & 8816.7 & 5946.7 \\
\hline \multirow[t]{2}{*}{ ERM1.0 } & 2010 & $Y$ & 3 & SE & 87.6 & 477.9 & 23.3 & 197.4 & 161.9 \\
\hline & & & & Max & 2290.0 & 3430.0 & 1180.0 & 9210.0 & 6270.0 \\
\hline \multicolumn{10}{|l|}{ Clinch River } \\
\hline \multirow{3}{*}{ CRM6.0 } & & & & Mean & 2892.5 & 8200.0 & 1777.5 & 6927.5 & 4782.5 \\
\hline & 2009 & $\mathrm{~N}$ & 4 & SE & 75.4 & 390.3 & 33.8 & 216.7 & 185.2 \\
\hline & & & & Max & 3060.0 & 9250.0 & 1840.0 & 7290.0 & 5300.0 \\
\hline \multirow{3}{*}{ CRM6.0 } & & & & Mean & 3113.3 & 8930.0 & 1926.7 & 7456.7 & 5466.7 \\
\hline & 2010 & $\mathrm{~N}$ & 3 & SE & 64.4 & 170.4 & 33.8 & 302.5 & 224.8 \\
\hline & & & & Max & 3240.0 & 9230.0 & 1970.0 & 7940.0 & 5910.0 \\
\hline
\end{tabular}

B-7 


\begin{tabular}{|c|c|c|c|c|c|c|c|c|c|}
\hline River/site & Year & Depurated $^{1}$ & $\mathrm{~N}$ & Statistic & $\mathrm{Ca}$ & $\mathrm{Fe}$ & $\mathrm{Mg}$ & $\mathrm{K}$ & $\mathrm{Na}$ \\
\hline & & & & Mean & 2333.3 & 522.0 & 1286.7 & 9290.0 & 4626.7 \\
\hline \multirow[t]{3}{*}{ CRM6.0 } & 2010 & $Y$ & 3 & SE & 24.0 & 55.8 & 14.5 & 352.8 & 627.8 \\
\hline & & & & Max & 2380.0 & 593.0 & 1310.0 & 9920.0 & 5380.0 \\
\hline & & & & Mean & 2823.3 & 9253.3 & 1636.7 & 6110.0 & 4170.0 \\
\hline \multirow[t]{3}{*}{ CRM3.5 } & 2010 & $\mathrm{~N}$ & 3 & SE & 63.3 & 170.7 & 20.3 & & 143.6 \\
\hline & & & & Max & 2950.0 & 9560.0 & 1670.0 & 6110.0 & 4390.0 \\
\hline & & & & Mean & 2480.0 & 1236.0 & 1230.0 & 9013.3 & 4670.0 \\
\hline \multirow[t]{3}{*}{ CRM3.5 } & 2010 & $Y$ & 3 & SE & 40.4 & 178.0 & 51.3 & 20.3 & 316.4 \\
\hline & & & & Max & 2530.0 & 1520.0 & 1300.0 & 9050.0 & 5290.0 \\
\hline & & & & Mean & 3012.5 & 8625.0 & 1760.0 & 7115.0 & 5315.0 \\
\hline \multirow[t]{3}{*}{ CRM1.5 } & 2009 & $\mathrm{~N}$ & 4 & SE & 46.4 & 294.2 & 39.4 & 139.4 & 182.1 \\
\hline & & & & Max & 3140.0 & 9410.0 & 1850.0 & 7370.0 & 5700.0 \\
\hline & & & & Mean & 2790.0 & 8316.7 & 1556.7 & 5993.3 & 4090.0 \\
\hline \multirow[t]{3}{*}{ CRM1.5 } & 2010 & $\mathrm{~N}$ & 3 & SE & 142.9 & 682.7 & 63.9 & 386.3 & 311.8 \\
\hline & & & & $\operatorname{Max}$ & 2980.0 & 9540.0 & 1660.0 & 6750.0 & 4680.0 \\
\hline & & & & Mean & 1925.0 & 1785.0 & 1115.0 & 6225.0 & 2860.0 \\
\hline \multirow[t]{3}{*}{ CRM1.5 } & 2009 & $Y$ & 2 & SE & 55.0 & 35.0 & 15.0 & 95.0 & 190.0 \\
\hline & & & & Max & 1980.0 & 1820.0 & 1130.0 & 6320.0 & 3050.0 \\
\hline & & & & Mean & 2226.7 & 810.3 & 1200.0 & 9336.7 & 5213.3 \\
\hline \multirow[t]{2}{*}{ CRM1.5 } & 2010 & Y & 3 & SE & 128.1 & 163.0 & 15.3 & 68.4 & 158.1 \\
\hline & & & & Max & 2410.0 & 1100.0 & 1220.0 & 9410.0 & 5510.0 \\
\hline \multicolumn{10}{|c|}{ Little Emory River } \\
\hline \multirow{3}{*}{ LERM1.0 } & & & & Mean & 1623.3 & 9943.3 & 1380.0 & 6336.7 & 4296.7 \\
\hline & 2009 & $\mathrm{~N}$ & 3 & SE & 80.1 & 263.1 & 28.9 & 105.9 & 291.7 \\
\hline & & & & Max & 1740.0 & 10300.0 & 1430.0 & 6480.0 & 4810.0 \\
\hline \multirow{3}{*}{ LERM1.0 } & & & & Mean & 1643.3 & 6526.7 & 1226.7 & 5933.3 & 4216.7 \\
\hline & 2010 & $\mathrm{~N}$ & 3 & SE & 31.8 & 368.6 & 42.6 & 150.3 & 67.4 \\
\hline & & & & Max & 1700.0 & 7200.0 & 1310.0 & 6200.0 & 4320.0 \\
\hline \multicolumn{10}{|c|}{ Tennessee River } \\
\hline \multirow{3}{*}{ TRM571.9 } & & & & Mean & 2103.3 & 9696.7 & 1540.0 & 5986.7 & 3403.3 \\
\hline & 2010 & $\mathrm{~N}$ & 3 & SE & 86.9 & 703.3 & 50.3 & 97.0 & 114.6 \\
\hline & & & & $\operatorname{Max}$ & 2200.0 & 10400.0 & 1600.0 & 6170.0 & 3620.0 \\
\hline \multirow{3}{*}{ TRM571.9 } & & & & Mean & 2226.7 & 1531.7 & 1130.0 & 8383.3 & 3896.7 \\
\hline & 2010 & Y & 3 & SE & 78.0 & 386.4 & 11.5 & 403.4 & 138.6 \\
\hline & & & & Max & 2360.0 & 2270.0 & 1150.0 & 9190.0 & 4170.0 \\
\hline \multirow{3}{*}{ TRM566.3 } & & & & Mean & 2583.3 & 10700.0 & 1810.0 & $<10200$ & 5620.0 \\
\hline & 2010 & $\mathrm{~N}$ & 3 & SE & 69.6 & 351.2 & 52.0 & & 276.8 \\
\hline & & & & Max & 2710.0 & 11400.0 & 1900.0 & & 6170.0 \\
\hline \multirow{3}{*}{ TRM566.3 } & & & & Mean & 2006.7 & 681.7 & 1180.0 & 8926.7 & 4046.7 \\
\hline & 2010 & $Y$ & 3 & SE & 84.5 & 150.6 & 5.8 & 100.4 & 402.9 \\
\hline & & & & Max & 2140.0 & 913.0 & 1190.0 & 9060.0 & 4850.0 \\
\hline \multirow{3}{*}{ TRM560.8 } & & & & Mean & 2560.0 & 10780.0 & 1896.7 & 7040.0 & 5356.7 \\
\hline & 2010 & $\mathrm{~N}$ & 3 & SE & 100.2 & 870.5 & 28.5 & & 233.8 \\
\hline & & & & Max & 2710.0 & 11700.0 & 1930.0 & 7040.0 & 5720.0 \\
\hline
\end{tabular}
prior to analysis. 


\section{APPENDIX C}

\section{MEAN CONCENTRATIONS OF ELEMENTS IN ADULT MAYFLIES}


Table C.1. Mean, standard error of the mean (SE), and maximum (Max) concentrations ( $\mu \mathrm{g} / \mathrm{g}$ dry weight) of bioaccumulative elements (total) of potential ecological concern in adult mayflies (Hexagenia bilineata) from the Emory River, Clinch River, and Tennessee River, 2009 and 2010. N $=$ Number of replicate samples. Values for means proceeded by a "<" symbol indicate that concentrations for all replicates were below the method detection limit (MDL); the numeral after the " $<$ " symbol is the highest MDL report among all replicates from a sample. Observations with mean and maximum concentrations but no SE indicate that the concentration was below the MDL in all but one replicate.

\begin{tabular}{|c|c|c|c|c|c|c|c|c|c|c|c|c|}
\hline River/site & Year & $\begin{array}{l}\text { Sex / adult } \\
\text { life stage }\end{array}$ & $\mathrm{N}$ & Statistic & As & $\mathrm{Cr}$ & $\mathrm{Cu}$ & $\mathrm{Pb}$ & $\mathrm{Hg}$ & $\mathrm{Ni}$ & $\mathrm{Se}$ & $\mathrm{Zn}$ \\
\hline \multicolumn{13}{|c|}{ Emory River } \\
\hline & & & & Mean & 0.148 & 0.298 & 27.88 & 0.153 & 0.073 & 0.175 & 4.83 & 87.3 \\
\hline \multirow[t]{3}{*}{ ERM4.5 } & 2009 & Ml & 4 & SE & 0.003 & 0.020 & 0.16 & 0.015 & 0.001 & 0.013 & 0.06 & 0.7 \\
\hline & & & & $\operatorname{Max}$ & 0.150 & 0.340 & 28.10 & 0.190 & 0.074 & 0.210 & 5.00 & 88.8 \\
\hline & & & & Mean & 0.523 & 0.163 & 14.03 & $<0.028$ & 0.031 & $<0.098$ & 7.00 & 241.3 \\
\hline \multirow[t]{3}{*}{ ERM2.8 } & 2010 & $\mathrm{FI}$ & 3 & SE & 0.003 & 0.012 & 0.27 & . & 0.001 & . & 0.25 & 2.3 \\
\hline & & & & $\operatorname{Max}$ & 0.530 & 0.180 & 14.40 & . & 0.032 & . & 7.50 & 246.0 \\
\hline & & & & Mean & 0.380 & 0.163 & 26.83 & $<0.029$ & 0.037 & $<0.097$ & 6.73 & 85.7 \\
\hline \multirow[t]{3}{*}{ ERM2.8 } & 2010 & Ml & 3 & SE & 0.015 & 0.007 & 0.72 & . & 0.000 & . & 0.15 & 1.6 \\
\hline & & & & Max & 0.400 & 0.170 & 27.70 & . & 0.037 & . & 7.00 & 87.8 \\
\hline & & & & Mean & 0.220 & 0.375 & 27.65 & 0.087 & 0.052 & 0.101 & 4.20 & 92.3 \\
\hline \multirow[t]{3}{*}{ ERM2 } & 2009 & MI & 2 & SE & 0.010 & 0.015 & 0.95 & 0.043 & 0.002 & 0.019 & 0.00 & 0.0 \\
\hline & & & & Max & 0.230 & 0.390 & 28.60 & 0.130 & 0.053 & 0.120 & 4.20 & 92.3 \\
\hline & & & & Mean & 0.500 & 0.170 & 14.47 & $<0.029$ & 0.028 & $<0.1$ & 8.17 & 198.0 \\
\hline \multirow[t]{3}{*}{ ERM2 } & 2010 & $\mathrm{FI}$ & 3 & SE & 0.000 & 0.012 & 0.32 & . & 0.001 & . & 0.23 & 4.4 \\
\hline & & & & Max & 0.500 & 0.190 & 15.00 & . & 0.029 & . & 8.40 & 205.0 \\
\hline & & & & Mean & 0.590 & 0.177 & 13.23 & $<0.028$ & 0.027 & $<0.1$ & 8.27 & 206.7 \\
\hline \multirow[t]{3}{*}{ ERM2 } & 2010 & FS & 3 & SE & 0.021 & 0.027 & 0.50 & . & 0.001 & . & 0.09 & 7.4 \\
\hline & & & & Max & 0.620 & 0.230 & 14.00 & . & 0.030 & . & 8.40 & 215.0 \\
\hline & & & & Mean & 0.363 & 0.200 & 22.90 & $<0.028$ & 0.031 & $<0.1$ & 7.63 & 91.9 \\
\hline \multirow[t]{3}{*}{ ERM2 } & 2010 & MI & 3 & SE & 0.003 & 0.006 & 0.15 & . & 0.002 & . & 0.12 & 0.7 \\
\hline & & & & Max & 0.370 & 0.210 & 23.10 & . & 0.034 & . & 7.80 & 92.9 \\
\hline & & & & Mean & 0.430 & 0.190 & 20.90 & $<0.029$ & 0.029 & $<0.1$ & 7.57 & 93.6 \\
\hline \multirow[t]{3}{*}{ ERM2 } & 2010 & MS & 3 & SE & 0.020 & 0.006 & 0.26 & . & 0.001 & . & 0.35 & 3.1 \\
\hline & & & & Max & 0.450 & 0.200 & 21.30 & . & 0.031 & . & 8.10 & 98.8 \\
\hline & & & & Mean & 0.345 & 0.445 & 30.35 & 0.156 & 0.058 & 0.083 & 6.50 & 82.7 \\
\hline \multirow[t]{3}{*}{ ERM1 } & 2009 & MI & 2 & SE & 0.035 & 0.005 & 0.95 & 0.074 & 0.003 & 0.003 & 0.00 & 5.6 \\
\hline & & & & Max & 0.380 & 0.450 & 31.30 & 0.230 & 0.060 & 0.086 & 6.50 & 88.2 \\
\hline & & & & Mean & 0.307 & 0.147 & 12.07 & $<0.027$ & 0.038 & $<0.096$ & 7.37 & 216.3 \\
\hline \multirow[t]{3}{*}{ ERM1 } & 2010 & FS & 3 & SE & 0.007 & 0.009 & 0.79 & . & 0.000 & . & 0.03 & 3.2 \\
\hline & & & & Max & 0.320 & 0.160 & 13.30 & . & 0.039 & . & 7.40 & 220.0 \\
\hline & & & & Mean & 0.320 & 0.240 & 24.90 & $<0.029$ & 0.048 & 0.100 & 6.47 & 96.8 \\
\hline \multirow[t]{3}{*}{ ERM1 } & 2010 & MI & 3 & SE & 0.046 & 0.025 & 0.92 & . & 0.002 & . & 0.43 & 1.5 \\
\hline & & & & Max & 0.410 & 0.290 & 26.70 & . & 0.050 & 0.100 & 6.90 & 98.5 \\
\hline & & & & Mean & 0.317 & 0.177 & 20.93 & $<0.029$ & 0.042 & $<0.1$ & 6.77 & 102.0 \\
\hline \multirow[t]{3}{*}{ ERM1 } & 2010 & MS & 3 & SE & 0.012 & 0.009 & 0.30 & . & 0.001 & . & 0.15 & 1.5 \\
\hline & & & & Max & 0.340 & 0.190 & 21.50 & . & 0.043 & . & 7.00 & 105.0 \\
\hline & & & & Mean & 0.283 & $<0.59$ & 12.63 & $<0.028$ & 0.050 & $<0.099$ & 7.97 & 208.3 \\
\hline \multirow[t]{2}{*}{ ERM0.6 } & 2010 & FS & 3 & SE & 0.007 & . & 0.28 & . & 0.002 & . & 0.19 & 8.0 \\
\hline & & & & Max & 0.290 & 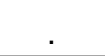 & 13.20 & . & 0.053 & . & 8.20 & 220.0 \\
\hline \multirow[t]{2}{*}{ ERM0.6 } & 2010 & $\mathrm{Ml}$ & 3 & Mean & 0.233 & $<0.76$ & 24.70 & $<0.027$ & 0.048 & $<0.095$ & 6.87 & 89.1 \\
\hline & & & & & & C-2 & & & & & & \\
\hline
\end{tabular}




\begin{tabular}{|c|c|c|c|c|c|c|c|c|c|c|c|c|}
\hline River/site & Year & $\begin{array}{l}\text { Sex / adult } \\
\text { life stage }{ }^{1}\end{array}$ & $\mathrm{~N}$ & Statistic & As & $\mathrm{Cr}$ & $\mathrm{Cu}$ & $\mathrm{Pb}$ & $\mathrm{Hg}$ & $\mathrm{Ni}$ & $\mathrm{Se}$ & $\mathrm{Zn}$ \\
\hline & & & & SE & 0.003 & & 0.15 & $\cdot$ & 0.001 & . & 0.15 & 0.8 \\
\hline & & & & Max & 0.240 & & 24.90 & . & 0.050 & . & 7.10 & 90.0 \\
\hline & & & & Mean & 0.230 & $<1.8$ & 21.40 & $<0.029$ & 0.065 & $<0.1$ & 7.20 & 103.7 \\
\hline \multirow[t]{2}{*}{ ERM0.6 } & 2010 & MS & 3 & SE & 0.000 & & 0.15 & . & 0.002 & . & 0.17 & 1.2 \\
\hline & & & & Max & 0.230 & & 21.70 & . & 0.069 & . & 7.50 & 106.0 \\
\hline \multicolumn{13}{|c|}{ Clinch River } \\
\hline & & & & Mean & 0.327 & 0.237 & 16.87 & 0.050 & 0.088 & 0.052 & 3.33 & 175.7 \\
\hline \multirow[t]{3}{*}{ CRM6 } & 2009 & FS & 3 & SE & 0.019 & 0.018 & 0.23 & 0.008 & 0.002 & 0.007 & 0.18 & 2.7 \\
\hline & & & & $\operatorname{Max}$ & 0.350 & 0.270 & 17.30 & 0.060 & 0.091 & 0.065 & 3.60 & 181.0 \\
\hline & & & & Mean & 0.360 & 0.277 & 24.47 & 0.065 & 0.095 & 0.060 & 3.10 & 100.0 \\
\hline \multirow[t]{2}{*}{ CRM6 } & 2009 & MS & 3 & SE & 0.040 & 0.028 & 0.69 & 0.002 & 0.008 & 0.007 & 0.06 & 6.0 \\
\hline & & & & $\operatorname{Max}$ & 0.430 & 0.310 & 25.30 & 0.069 & 0.110 & 0.072 & 3.20 & 112.0 \\
\hline \multirow{3}{*}{ CRM6 } & & & & Mean & 0.123 & 12.700 & 27.30 & $<0.029$ & 0.113 & $<0.1$ & 3.88 & 93.8 \\
\hline & 2010 & $\mathrm{Ml}$ & 6 & SE & 0.005 & & 0.24 & . & 0.004 & . & 0.06 & 1.5 \\
\hline & & & & $\operatorname{Max}$ & 0.140 & 12.700 & 27.90 & & 0.130 & . & 4.10 & 98.7 \\
\hline \multirow{3}{*}{ CRM3.5 } & & & & Mean & 0.240 & 0.240 & 15.27 & $<0.028$ & 0.059 & $<0.098$ & 6.20 & 203.3 \\
\hline & 2010 & $\mathrm{FI}$ & 3 & SE & 0.012 & 0.025 & 0.38 & . & 0.001 & . & 0.15 & 3.7 \\
\hline & & & & $\operatorname{Max}$ & 0.260 & 0.290 & 15.70 & & 0.061 & & 6.40 & 208.0 \\
\hline \multirow{3}{*}{ CRM3.5 } & & & & Mean & 0.240 & 0.230 & 13.17 & $<0.035$ & 0.058 & 0.330 & 6.50 & 197.0 \\
\hline & 2010 & FS & 3 & SE & 0.021 & & 0.73 & & 0.002 & & 0.06 & 9.6 \\
\hline & & & & Max & 0.280 & 0.230 & 14.30 & & 0.061 & 0.330 & 6.60 & 212.0 \\
\hline \multirow{3}{*}{ CRM3.5 } & & & & Mean & 0.217 & 0.253 & 27.20 & $<0.029$ & 0.078 & $<0.1$ & 5.97 & 94.2 \\
\hline & 2010 & MI & 3 & SE & 0.015 & 0.007 & 0.67 & . & 0.001 & . & 0.12 & 1.5 \\
\hline & & & & $\operatorname{Max}$ & 0.240 & 0.260 & 28.50 & . & 0.080 & . & 6.20 & 96.4 \\
\hline \multirow{3}{*}{ CRM1.5 } & & & & Mean & 0.170 & 0.230 & 13.80 & 0.062 & 0.019 & 0.110 & 3.40 & 217.0 \\
\hline & 2009 & $\mathrm{FI}$ & 1 & SE & . & & . & . & & . & & \\
\hline & & & & Max & 0.170 & 0.230 & 13.80 & 0.062 & 0.019 & 0.110 & 3.40 & 217.0 \\
\hline \multirow{3}{*}{ CRM1.5 } & & & & Mean & 0.290 & 0.517 & 30.30 & 0.085 & 0.036 & 0.105 & 4.83 & 87.7 \\
\hline & 2009 & MI & 3 & SE & 0.020 & 0.122 & 2.40 & 0.004 & 0.001 & 0.022 & 0.27 & 4.7 \\
\hline & & & & Max & 0.310 & 0.750 & 32.80 & 0.089 & 0.038 & 0.150 & 5.20 & 92.7 \\
\hline \multirow{3}{*}{ CRM1.5 } & & & & Mean & 0.200 & 0.233 & 17.83 & $<0.027$ & 0.043 & $<0.094$ & 6.27 & 186.3 \\
\hline & 2010 & $\mathrm{FI}$ & 3 & SE & 0.031 & 0.003 & 0.64 & . & 0.002 & . & 0.22 & 10.4 \\
\hline & & & & Max & 0.260 & 0.240 & 19.10 & . & 0.046 & . & 6.70 & 205.0 \\
\hline \multirow{3}{*}{ CRM1.5 } & & & & Mean & 0.163 & 0.283 & 26.37 & $<0.027$ & 0.052 & $<0.096$ & 5.33 & 85.7 \\
\hline & 2010 & Ml & 3 & SE & 0.007 & 0.020 & 0.18 & . & 0.002 & . & 0.07 & 3.0 \\
\hline & & & & Max & 0.170 & 0.320 & 26.70 & . & 0.055 & . & 5.40 & 90.4 \\
\hline \multicolumn{13}{|c|}{ Little Emory River } \\
\hline \multirow{3}{*}{ LERM1.0 } & & & & Mean & 0.153 & 0.210 & 14.90 & 0.026 & 0.058 & 0.081 & 3.58 & 197.0 \\
\hline & 2009 & $\mathrm{FI}$ & 4 & SE & 0.019 & 0.007 & 0.46 & . & 0.001 & 0.012 & 0.06 & 10.1 \\
\hline & & & & Max & 0.200 & 0.220 & 16.20 & 0.026 & 0.061 & 0.110 & 3.70 & 217.0 \\
\hline \multirow{3}{*}{ LERM1.0 } & & & & Mean & 0.173 & 0.275 & 22.25 & $0.023^{2}$ & 0.068 & 0.092 & 3.35 & 88.9 \\
\hline & 2009 & Ml & 4 & SE & 0.017 & 0.046 & 0.10 & 0.009 & 0.002 & 0.003 & 0.03 & 2.3 \\
\hline & & & & Max & 0.220 & 0.410 & 22.50 & 0.040 & 0.070 & 0.099 & 3.40 & 94.1 \\
\hline \multicolumn{13}{|c|}{ Tennessee River } \\
\hline \multirow{3}{*}{ TRM572 } & & & & Mean & 0.203 & 0.223 & 15.47 & $0.069^{3}$ & 0.021 & 0.150 & 2.00 & 200.3 \\
\hline & 2010 & FS & 3 & SE & 0.032 & 0.003 & 1.29 & 0.042 & 0.002 & & 0.00 & 14.2 \\
\hline & & & & $\operatorname{Max}$ & 0.260 & 0.230 & 18.00 & 0.110 & 0.024 & 0.150 & 2.00 & 216.0 \\
\hline & & & & Mean & 0.110 & 0.253 & 25.30 & $<0.028$ & 0.037 & $<0.099$ & 1.50 & 97.0 \\
\hline TRM572 & 2010 & Ml & 3 & SE & 0.015 & 0.015 & 0.92 & . & 0.002 & . & 0.00 & 2.5 \\
\hline & & & & Max & 0.140 & 0.280 & 27.10 & . & 0.040 & . & 1.50 & 102.0 \\
\hline TRM572 & 2010 & MS & 3 & Mean & 0.207 & 0.240 & 25.20 & $<0.029$ & 0.029 & $<0.1$ & 1.80 & 102.5 \\
\hline
\end{tabular}




\begin{tabular}{|c|c|c|c|c|c|c|c|c|c|c|c|c|}
\hline River/site & Year & $\begin{array}{l}\text { Sex / adult } \\
\text { life stage }\end{array}$ & $\mathrm{N}$ & Statistic & As & $\mathrm{Cr}$ & $\mathrm{Cu}$ & $\mathrm{Pb}$ & $\mathrm{Hg}$ & $\mathrm{Ni}$ & Se & $\mathrm{Zn}$ \\
\hline & & & & SE & 0.007 & 0.015 & 0.35 & & 0.001 & . & 0.06 & 2.3 \\
\hline & & & & Max & 0.220 & 0.270 & 25.60 & & 0.031 & & 1.90 & 107.0 \\
\hline & & & & Mean & 0.190 & 0.505 & 13.85 & $<0.013$ & $<0.05$ & 0.059 & 3.80 & 223.5 \\
\hline \multirow[t]{3}{*}{ TRM567 } & 2009 & $\mathrm{FI}$ & 2 & SE & 0.020 & 0.025 & 0.25 & & & 0.016 & 0.10 & 5.5 \\
\hline & & & & Max & 0.210 & 0.530 & 14.10 & . & . & 0.075 & 3.90 & 229.0 \\
\hline & & & & Mean & 0.225 & 0.465 & 16.23 & 0.019 & 0.130 & 0.068 & 3.20 & 173.0 \\
\hline \multirow[t]{2}{*}{ TRM567 } & 2009 & FS & 4 & $\mathrm{SE}$ & 0.009 & 0.018 & 0.38 & 0.000 & & 0.010 & 0.06 & 5.2 \\
\hline & & & & $\operatorname{Max}$ & 0.240 & 0.510 & 17.20 & 0.020 & 0.130 & 0.092 & 3.30 & 182.0 \\
\hline & & & & Mean & 0.165 & 0.555 & 24.55 & 0.017 & $<0.063$ & 0.086 & 2.88 & 87.5 \\
\hline \multirow[t]{2}{*}{ TRM567 } & 2009 & $\mathrm{Ml}$ & 4 & SE & 0.009 & 0.023 & 0.23 & 0.003 & & 0.019 & 0.11 & 2.9 \\
\hline & & & & Max & 0.190 & 0.600 & 25.00 & 0.026 & & 0.140 & 3.20 & 92.5 \\
\hline \multirow{3}{*}{ TRM567 } & & & & Mean & 0.195 & 0.565 & 22.15 & 0.025 & $<0.056$ & 0.081 & 2.80 & 92.9 \\
\hline & 2009 & MS & 4 & SE & 0.012 & 0.016 & 0.29 & 0.004 & & 0.005 & 0.10 & 5.0 \\
\hline & & & & Max & 0.220 & 0.600 & 22.90 & 0.035 & & 0.090 & 3.10 & 107.0 \\
\hline & & & & Mean & 0.173 & 0.155 & 12.22 & $<0.029$ & 0.031 & $<0.1$ & 4.47 & 204.3 \\
\hline \multirow[t]{2}{*}{ TRM567 } & 2010 & FS & 6 & SE & 0.013 & 0.004 & 0.27 & . & 0.002 & . & 0.19 & 3.0 \\
\hline & & & & Max & 0.230 & 0.170 & 13.20 & . & 0.039 & . & 5.30 & 213.0 \\
\hline & & & & Mean & 0.128 & 0.237 & 26.43 & $<0.029$ & 0.052 & $<0.1$ & 3.55 & 91.7 \\
\hline \multirow[t]{2}{*}{ TRM567 } & 2010 & MI & 6 & SE & 0.005 & 0.010 & 0.37 & & 0.002 & . & 0.07 & 1.0 \\
\hline & & & & Max & 0.140 & 0.280 & 28.20 & & 0.057 & . & 3.80 & 94.8 \\
\hline \multirow{3}{*}{ TRM567 } & & & & Mean & 0.145 & 0.210 & 22.20 & $<0.03$ & 0.045 & $<0.1$ & 3.68 & 99.7 \\
\hline & 2010 & MS & 6 & SE & 0.004 & 0.004 & 0.22 & & 0.002 & . & 0.06 & 1.1 \\
\hline & & & & Max & 0.160 & 0.220 & 22.90 & . & 0.053 & . & 3.90 & 104.0 \\
\hline & & & & Mean & 0.143 & 0.200 & 29.30 & 0.043 & 0.029 & 0.067 & 3.05 & 78.8 \\
\hline \multirow[t]{2}{*}{ TRM563 } & 2009 & Ml & 4 & SE & 0.006 & 0.025 & 0.36 & 0.007 & 0.001 & 0.004 & 0.06 & 2.8 \\
\hline & & & & Max & 0.160 & 0.270 & 30.10 & 0.054 & 0.032 & 0.076 & 3.20 & 84.0 \\
\hline \multirow{3}{*}{ TRM563 } & & & & Mean & 0.137 & 0.207 & 11.40 & $<0.026$ & 0.029 & $<0.092$ & 3.87 & 208.7 \\
\hline & 2010 & FS & 3 & SE & 0.009 & 0.003 & 0.56 & 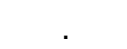 & 0.001 & . & 0.15 & 8.0 \\
\hline & & & & Max & 0.150 & 0.210 & 12.10 & & 0.031 & . & 4.10 & 224.0 \\
\hline \multirow{3}{*}{ TRM563 } & & & & Mean & 0.093 & 0.387 & 27.37 & $<0.028$ & 0.049 & $<0.099$ & 3.13 & 93.6 \\
\hline & 2010 & MI & 3 & SE & 0.003 & 0.015 & 0.73 & . & 0.002 & . & 0.03 & 1.0 \\
\hline & & & & Max & 0.099 & 0.410 & 28.80 & . & 0.053 & . & 3.20 & 95.1 \\
\hline \multirow{3}{*}{ TRM563 } & & & & Mean & 0.180 & 0.267 & 22.87 & $<0.029$ & 0.045 & $<0.1$ & 3.10 & 95.7 \\
\hline & 2010 & MS & 3 & SE & 0.017 & 0.007 & 0.44 & & 0.002 & . & 0.12 & 2.2 \\
\hline & & & & Max & 0.210 & 0.280 & 23.40 & & 0.048 & . & 3.30 & 100.0 \\
\hline
\end{tabular}

\footnotetext{
1"FS" = Female subimago; "FI" = female imago; "MS" = male subimago; "MI" = male imago

${ }^{2}$ Only 3 replicates had concentrations above the method detection limit; descriptive statistics based on only those 3 replicates.

${ }^{3}$ Only 2 replicates had concentrations above the method detection limit; descriptive statistics based on only those 2 replicates.
} 
Table C.2. Mean, standard error of the mean (SE), and maximum (Max) concentrations ( $\mu \mathrm{g} / \mathrm{g}$ dry weight) of elements (total) of potential ecological concern (excluding those of bioaccumulative concern) in adult mayflies (Hexagenia bilineata) from the Emory River, Clinch

River, and Tennessee River, 2009 and 2010. $\mathrm{N}=$ Number of replicate samples. Values for means proceeded by a "<" symbol indicate that concentrations for all replicates were below the method detection limit (MDL); the numeral after the "<" symbol is the highest MDL report among all replicates from a sample. Observations with mean and maximum concentrations but no SE indicate that the concentration was below the MDL

\begin{tabular}{|c|c|c|c|c|c|c|c|c|c|c|c|c|c|c|c|c|c|}
\hline River/site & Year & $\begin{array}{l}\text { Sex / adult } \\
\text { life stage }{ }^{1}\end{array}$ & $\mathrm{~N}$ & Statistic & Al & $\mathrm{Sb}$ & $\mathrm{Ba}$ & $\mathrm{Be}$ & B & $\mathrm{Cd}$ & Co & $\mathrm{Mn}$ & Mo & $\mathrm{Ag}$ & $\mathrm{Sr}$ & $\mathrm{TI}$ & V \\
\hline \multicolumn{18}{|c|}{ Emory River } \\
\hline & & & & Mean & 52.75 & $<0.019$ & 1.43 & $<0.033$ & 0.84 & 0.130 & 0.650 & 8.03 & 0.385 & 0.0545 & 0.803 & $<0.015$ & 0.113 \\
\hline \multirow[t]{3}{*}{ ERM4.5 } & 2009 & $\mathrm{Ml}$ & 4 & SE & 4.14 & . & 0.06 & . & 0.07 & 0.007 & 0.009 & 0.67 & 0.006 & 0.0006 & 0.028 & . & 0.006 \\
\hline & & & & Max & 63.40 & . & 1.60 & . & 0.98 & 0.150 & 0.670 & 9.30 & 0.400 & 0.0560 & 0.880 & . & 0.130 \\
\hline & & & & Mean & 27.10 & $<0.015$ & 0.93 & $<0.03$ & 0.67 & 0.021 & 0.400 & 4.73 & 0.567 & 0.0110 & 0.643 & $<0.014$ & 0.127 \\
\hline \multirow[t]{3}{*}{ ERM2.8 } & 2010 & $\mathrm{FI}$ & 3 & SE & & & 0.01 & & 0.10 & 0.003 & 0.006 & 0.03 & 0.018 & 0.0006 & 0.038 & & 0.003 \\
\hline & & & & Max & 27.10 & & 0.94 & . & 0.87 & 0.026 & 0.410 & 4.80 & 0.600 & 0.0120 & 0.700 & & 0.130 \\
\hline & & & & Mean & $<4.1$ & $<0.015$ & 1.73 & $<0.03$ & 0.76 & 0.049 & 0.387 & 2.10 & 0.353 & 0.0173 & 1.400 & 0.0193 & 0.163 \\
\hline \multirow[t]{3}{*}{ ERM2.8 } & 2010 & $\mathrm{Ml}$ & 3 & SE & . & . & 0.03 & . & 0.22 & 0.005 & 0.012 & 0.06 & 0.009 & 0.0003 & 0.000 & 0.0035 & 0.003 \\
\hline & & & & Max & . & . & 1.80 & . & 1.20 & 0.055 & 0.410 & 2.20 & 0.370 & 0.0180 & 1.400 & 0.0260 & 0.170 \\
\hline & & & & Mean & 11.05 & $<0.019$ & 1.25 & $<0.033$ & 0.59 & 0.300 & 0.970 & 2.30 & 0.410 & 0.0370 & 0.830 & 0.0335 & 0.150 \\
\hline \multirow[t]{3}{*}{ ERM2 } & 2009 & $\mathrm{Ml}$ & 2 & SE & 4.55 & . & 0.05 & . & 0.04 & 0.040 & 0.030 & 0.20 & 0.010 & 0.0030 & 0.010 & 0.0005 & 0.010 \\
\hline & & & & Max & 15.60 & . & 1.30 & . & 0.63 & 0.340 & 1.000 & 2.50 & 0.420 & 0.0400 & 0.840 & 0.0340 & 0.160 \\
\hline & & & & Mean & $5.05^{2}$ & $<0.015$ & 1.03 & $<0.03$ & 0.82 & 0.087 & 0.710 & 3.83 & 0.717 & 0.0064 & 0.733 & 0.0267 & 0.170 \\
\hline \multirow[t]{3}{*}{ ERM2 } & 2010 & $\mathrm{FI}$ & 3 & SE & 0.55 & . & 0.03 & . & 0.02 & 0.005 & 0.017 & 0.03 & 0.028 & 0.0000 & 0.009 & 0.0015 & 0.006 \\
\hline & & & & Max & 5.60 & . & 1.10 & . & 0.86 & 0.094 & 0.740 & 3.90 & 0.750 & 0.0064 & 0.750 & 0.0290 & 0.180 \\
\hline & & & & Mean & $6.65^{2}$ & $<0.015$ & 1.20 & $<0.03$ & 1.83 & 0.071 & 0.697 & 4.00 & 1.333 & 0.0060 & 0.730 & 0.0223 & 0.153 \\
\hline \multirow[t]{3}{*}{ ERM2 } & 2010 & FS & 3 & SE & 1.65 & . & 0.06 & . & 0.20 & 0.013 & 0.048 & 0.15 & 0.033 & 0.0006 & 0.040 & 0.0034 & 0.022 \\
\hline & & & & Max & 8.30 & . & 1.30 & . & 2.20 & 0.088 & 0.790 & 4.30 & 1.400 & 0.0069 & 0.800 & 0.0290 & 0.180 \\
\hline & & & & Mean & 5.40 & $0.0295^{2}$ & 1.67 & $<0.033$ & 1.40 & 0.127 & 0.687 & 2.10 & 0.393 & 0.0110 & 1.200 & 0.0317 & 0.230 \\
\hline \multirow[t]{3}{*}{ ERM2 } & 2010 & $\mathrm{MI}$ & 3 & SE & 0.70 & 0.0145 & 0.03 & . & 0.15 & 0.012 & 0.009 & 0.06 & 0.007 & 0.0006 & 0.000 & 0.0032 & 0.010 \\
\hline & & & & Max & 6.70 & 0.044 & 1.70 & . & 1.70 & 0.150 & 0.700 & 2.20 & 0.400 & 0.0120 & 1.200 & 0.0380 & 0.240 \\
\hline & & & & Mean & 7.03 & 0.017 & 1.70 & $<0.03$ & 1.97 & 0.095 & 0.693 & 2.37 & 0.933 & 0.0093 & 1.100 & 0.0260 & 0.233 \\
\hline \multirow[t]{3}{*}{ ERM2 } & 2010 & MS & 3 & SE & 0.03 & & 0.00 & . & 0.20 & 0.003 & 0.055 & 0.09 & 0.030 & 0.0004 & 0.000 & 0.0042 & 0.009 \\
\hline & & & & Max & 7.10 & 0.017 & 1.70 & . & 2.30 & 0.099 & 0.780 & 2.50 & 0.990 & 0.0100 & 1.100 & 0.0340 & 0.250 \\
\hline & & & & Mean & 8.00 & 0.032 & 1.20 & $<0.031$ & 0.65 & 0.345 & 0.685 & 2.30 & 0.645 & 0.0125 & 0.965 & 0.0470 & 0.355 \\
\hline \multirow[t]{3}{*}{ ERM1 } & 2009 & $\mathrm{Ml}$ & 2 & SE & 1.60 & . & 0.10 & . & 0.06 & 0.025 & 0.035 & 0.10 & 0.135 & 0.0005 & 0.135 & 0.0010 & 0.015 \\
\hline & & & & Max & 9.60 & 0.032 & 1.30 & . & 0.70 & 0.370 & 0.720 & 2.40 & 0.780 & 0.0130 & 1.100 & 0.0480 & 0.370 \\
\hline & & & & Mean & 8.50 & $<0.015$ & 1.01 & $<0.031$ & 0.75 & 0.053 & 0.677 & 4.57 & 0.777 & 0.0073 & 0.693 & 0.0180 & 0.086 \\
\hline \multirow[t]{2}{*}{ ERM1 } & 2010 & FS & 3 & SE & . & . & 0.10 & . & 0.04 & 0.010 & 0.084 & 0.92 & 0.003 & 0.0002 & 0.032 & . & 0.008 \\
\hline & & & & Max & 8.50 & . & 1.20 & . & 0.82 & 0.064 & 0.830 & 6.40 & 0.780 & 0.0076 & 0.730 & 0.0180 & 0.095 \\
\hline
\end{tabular}




\begin{tabular}{|c|c|c|c|c|c|c|c|c|c|c|c|c|c|c|c|c|c|}
\hline River/site & Year & $\begin{array}{l}\text { Sex / adult } \\
\text { life stage }\end{array}$ & $\mathrm{N}$ & Statistic & $\mathrm{Al}$ & $\mathrm{Sb}$ & $\mathrm{Ba}$ & $\mathrm{Be}$ & B & $\mathrm{Cd}$ & Co & $\mathrm{Mn}$ & Mo & $\mathrm{Ag}$ & $\mathrm{Sr}$ & $\mathrm{TI}$ & V \\
\hline & & & & Mean & $<4.2$ & 0.014 & 1.40 & $<0.031$ & 2.23 & 0.133 & 0.807 & 2.00 & 0.383 & 0.0157 & 0.900 & 0.0227 & 0.177 \\
\hline \multirow[t]{3}{*}{ ERM1 } & 2010 & MI & 3 & SE & . & . & 0.00 & . & 0.56 & 0.007 & 0.026 & 0.00 & 0.003 & 0.0007 & 0.030 & 0.0009 & 0.012 \\
\hline & & & & Max & . & 0.014 & 1.40 & . & 3.30 & 0.140 & 0.850 & 2.00 & 0.390 & 0.0170 & 0.930 & 0.0240 & 0.200 \\
\hline & & & & Mean & 6.00 & $<0.015$ & 1.63 & $<0.031$ & 1.47 & 0.087 & 0.680 & 2.93 & 0.677 & 0.0120 & 1.200 & $0.0195^{2}$ & 0.147 \\
\hline \multirow[t]{3}{*}{ ERM1 } & 2010 & MS & 3 & SE & . & . & 0.03 & . & 0.15 & 0.006 & 0.029 & 0.69 & 0.009 & 0.0006 & 0.000 & 0.0025 & 0.003 \\
\hline & & & & Max & 6.00 & . & 1.70 & . & 1.70 & 0.100 & 0.730 & 4.30 & 0.690 & 0.0130 & 1.200 & 0.0220 & 0.150 \\
\hline & & & & Mean & $<4.0$ & $<0.015$ & 0.76 & $<0.03$ & 0.58 & 0.157 & 0.867 & 3.73 & 0.760 & 0.0073 & 0.723 & 0.0250 & 0.147 \\
\hline \multirow[t]{3}{*}{ ERM0.6 } & 2010 & FS & 3 & SE & . & . & 0.02 & . & 0.08 & 0.022 & 0.024 & 0.30 & 0.015 & 0.0006 & 0.012 & 0.0066 & 0.009 \\
\hline & & & & Max & . & & 0.78 & . & 0.70 & 0.200 & 0.900 & 4.30 & 0.790 & 0.0084 & 0.740 & 0.0380 & 0.160 \\
\hline & & & & Mean & 4.40 & 0.017 & 1.27 & $<0.029$ & 0.84 & 0.082 & 0.603 & 2.27 & 0.333 & 0.0153 & 0.763 & 0.0163 & 0.163 \\
\hline \multirow[t]{3}{*}{ ERM0.6 } & 2010 & MI & 3 & SE & 0.25 & . & 0.03 & . & 0.06 & 0.008 & 0.032 & 0.03 & 0.003 & 0.0003 & 0.023 & 0.0013 & 0.003 \\
\hline & & & & Max & 4.70 & 0.017 & 1.30 & . & 0.95 & 0.094 & 0.660 & 2.30 & 0.340 & 0.0160 & 0.810 & 0.0190 & 0.170 \\
\hline & & & & Mean & $<4.2$ & $<0.015$ & 1.30 & $<0.03$ & 0.56 & 0.213 & 0.877 & 1.97 & 0.640 & 0.0130 & 1.033 & 0.0353 & 0.193 \\
\hline \multirow[t]{2}{*}{ ERM0.6 } & 2010 & MS & 3 & SE & . & & 0.20 & . & 0.05 & 0.015 & 0.012 & 0.03 & 0.006 & 0.0000 & 0.033 & 0.0034 & 0.003 \\
\hline & & & & Max & . & . & 1.70 & . & 0.66 & 0.240 & 0.900 & 2.00 & 0.650 & 0.0130 & 1.100 & 0.0420 & 0.200 \\
\hline \multicolumn{18}{|c|}{$\underline{\text { Clinch River }}$} \\
\hline & & & & Mean & 5.60 & $<0.019$ & 0.87 & $<0.033$ & 0.80 & 0.140 & 0.447 & 3.53 & 0.507 & 0.0133 & 0.743 & $<0.015$ & 0.074 \\
\hline \multirow[t]{3}{*}{ CRM6 } & 2009 & FS & 3 & SE & 2.12 & . & 0.12 & . & 0.30 & 0.006 & 0.009 & 0.41 & 0.007 & 0.0009 & 0.019 & . & \\
\hline & & & & Max & 9.70 & . & 1.10 & . & 1.40 & 0.150 & 0.460 & 4.30 & 0.520 & 0.0150 & 0.780 & . & 0.074 \\
\hline & & & & Mean & 6.07 & $<0.019$ & 1.30 & $<0.033$ & 1.40 & 0.200 & 0.463 & 2.27 & 0.477 & 0.0190 & 1.200 & $<0.015$ & 0.074 \\
\hline \multirow[t]{3}{*}{ CRM6 } & 2009 & MS & 3 & SE & 1.51 & . & 0.12 & . & 0.10 & 0.012 & 0.034 & 0.07 & 0.035 & 0.0015 & 0.058 & . & 0.007 \\
\hline & & & & Max & 9.00 & & 1.50 & . & 1.50 & 0.220 & 0.530 & 2.40 & 0.540 & 0.0220 & 1.300 & . & 0.087 \\
\hline & & & & Mean & 5.20 & $<0.015$ & 0.63 & $<0.031$ & 0.53 & 0.353 & 0.792 & 2.28 & 0.352 & 0.0263 & 0.698 & $<0.014$ & 0.128 \\
\hline \multirow[t]{3}{*}{ CRM6 } & 2010 & MI & 6 & SE & . & . & 0.02 & . & 0.05 & 0.018 & 0.009 & 0.14 & 0.005 & 0.0006 & 0.024 & . & 0.003 \\
\hline & & & & Max & 5.20 & . & 0.68 & . & 0.77 & 0.400 & 0.820 & 2.90 & 0.370 & 0.0280 & 0.740 & . & 0.140 \\
\hline & & & & Mean & $<4.0$ & $<0.014$ & 0.58 & $<0.029$ & 0.83 & 0.293 & 0.833 & 3.17 & 0.487 & 0.0102 & 0.630 & 0.0190 & 0.183 \\
\hline \multirow[t]{3}{*}{ CRM3.5 } & 2010 & $\mathrm{FI}$ & 3 & SE & . & . & 0.01 & . & 0.03 & 0.018 & 0.030 & 0.03 & 0.003 & 0.0004 & 0.006 & 0.0015 & 0.003 \\
\hline & & & & Max & . & . & 0.60 & . & 0.89 & 0.320 & 0.890 & 3.20 & 0.490 & 0.0110 & 0.640 & 0.0220 & 0.190 \\
\hline & & & & Mean & $<5.0$ & $<0.018$ & 0.74 & $<0.03$ & $0.57^{2}$ & 0.220 & 0.693 & 3.13 & 0.650 & 0.0085 & 0.647 & 0.0197 & 0.193 \\
\hline \multirow[t]{3}{*}{ CRM3.5 } & 2010 & FS & 3 & SE & . & . & 0.09 & . & 0.11 & 0.012 & 0.012 & 0.13 & 0.026 & 0.0008 & 0.020 & 0.0022 & 0.019 \\
\hline & & & & Max & . & . & 0.92 & . & 0.67 & 0.240 & 0.710 & 3.40 & 0.690 & 0.0097 & 0.680 & 0.0240 & 0.230 \\
\hline & & & & Mean & $<4.1$ & $<0.015$ & 0.83 & $<0.03$ & 1.08 & 0.357 & 0.787 & 2.07 & 0.427 & 0.0157 & 0.850 & 0.0310 & 0.243 \\
\hline \multirow[t]{3}{*}{ CRM3.5 } & 2010 & $\mathrm{MI}$ & 3 & SE & . & . & 0.04 & . & 0.17 & 0.007 & 0.003 & 0.03 & 0.009 & 0.0003 & 0.046 & 0.0050 & 0.007 \\
\hline & & & & Max & . & . & 0.90 & . & 1.40 & 0.370 & 0.790 & 2.10 & 0.440 & 0.0160 & 0.940 & 0.0410 & 0.250 \\
\hline & & & & Mean & 1.10 & $<0.018$ & 0.50 & $<0.031$ & 0.14 & 0.220 & 0.720 & 4.90 & 0.390 & 0.0110 & 0.620 & $<0.014$ & 0.100 \\
\hline \multirow[t]{2}{*}{ CRM1.5 } & 2009 & $\mathrm{FI}$ & 1 & SE & . & . & . & . & . & . & . & . & & . & . & . & . \\
\hline & & & & Max & 1.10 & . & 0.50 & $<0.0048$ & 0.14 & 0.220 & 0.720 & 4.90 & 0.390 & 0.0110 & 0.620 & . & 0.100 \\
\hline
\end{tabular}




\begin{tabular}{|c|c|c|c|c|c|c|c|c|c|c|c|c|c|c|c|c|c|}
\hline River/site & Year & $\begin{array}{l}\text { Sex / adult } \\
\text { life stage }\end{array}$ & $\mathrm{N}$ & Statistic & $\mathrm{Al}$ & $\mathrm{Sb}$ & $\mathrm{Ba}$ & $\mathrm{Be}$ & B & $\mathrm{Cd}$ & Co & $\mathrm{Mn}$ & Mo & $\mathrm{Ag}$ & $\mathrm{Sr}$ & $\mathrm{TI}$ & $\mathrm{V}$ \\
\hline & & & & Mean & 5.37 & $<0.028$ & 0.91 & $<0.049$ & 1.07 & 0.737 & 0.853 & 2.20 & 0.443 & 0.0106 & 0.880 & $0.0235^{2}$ & 0.357 \\
\hline \multirow[t]{3}{*}{ CRM1.5 } & 2009 & MI & 3 & SE & 1.88 & . & 0.09 & . & 0.22 & 0.166 & 0.077 & 0.15 & 0.020 & 0.0007 & 0.046 & 0.0035 & 0.046 \\
\hline & & & & Max & 8.90 & . & 1.10 & . & 1.50 & 1.000 & 1.000 & 2.50 & 0.480 & 0.0120 & 0.970 & 0.0270 & 0.440 \\
\hline & & & & Mean & $<3.9$ & $<0.014$ & 0.45 & $<0.029$ & $0.61^{2}$ & 0.563 & 0.917 & 3.23 & 0.437 & 0.0065 & 0.500 & 0.0190 & 0.170 \\
\hline \multirow[t]{3}{*}{ CRM1.5 } & 2010 & $\mathrm{FI}$ & 3 & SE & . & . & 0.03 & . & 0.13 & 0.042 & 0.026 & 0.12 & 0.009 & 0.0003 & 0.031 & . & 0.006 \\
\hline & & & & Max & . & & 0.50 & . & 0.74 & 0.610 & 0.960 & 3.40 & 0.450 & 0.0068 & 0.540 & 0.0190 & 0.180 \\
\hline & & & & Mean & $<3.9$ & $<0.014$ & 0.68 & $<0.029$ & 0.60 & 0.623 & 0.880 & 2.10 & 0.353 & 0.0092 & 0.763 & 0.0270 & 0.223 \\
\hline \multirow[t]{2}{*}{ CRM1.5 } & 2010 & MI & 3 & SE & . & . & 0.02 & . & 0.11 & 0.022 & 0.032 & 0.21 & 0.018 & 0.0003 & 0.035 & 0.0021 & 0.015 \\
\hline & & & & Max & . & . & 0.72 & . & 0.77 & 0.650 & 0.930 & 2.50 & 0.380 & 0.0098 & 0.830 & 0.0310 & 0.250 \\
\hline \multicolumn{18}{|c|}{ Little Emory River } \\
\hline & & & & Mean & $1.83^{3}$ & $<0.019$ & 0.87 & $<0.0032$ & 0.72 & 0.648 & 1.775 & 3.45 & 0.365 & 0.1725 & 0.518 & $<0.015$ & $0.071^{3}$ \\
\hline \multirow[t]{3}{*}{ LERM1.0 } & 2009 & $\mathrm{FI}$ & 4 & SE & 0.39 & . & 0.01 & . & 0.20 & 0.041 & 0.063 & 0.13 & 0.003 & 0.0025 & 0.014 & . & 0.003 \\
\hline & & & & Max & 2.60 & . & 0.89 & . & 1.30 & 0.750 & 1.900 & 3.70 & 0.370 & 0.1800 & 0.540 & . & 0.075 \\
\hline & & & & Mean & 2.08 & $<0.019$ & 1.43 & $<0.0032$ & 0.82 & 0.723 & 1.750 & 2.00 & 0.358 & 0.2325 & 0.920 & $<0.015$ & 0.067 \\
\hline \multirow[t]{2}{*}{ LERM1.0 } & 2009 & MI & 4 & SE & 0.53 & & 0.09 & . & 0.22 & 0.021 & 0.029 & 0.04 & 0.017 & 0.0048 & 0.048 & 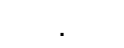 & 0.005 \\
\hline & & & & Max & 3.60 & & 1.60 & . & 1.40 & 0.760 & 1.800 & 2.10 & 0.390 & 0.2400 & 1.000 & . & 0.077 \\
\hline \multicolumn{18}{|c|}{ Tennessee River } \\
\hline & & & & Mean & 6.20 & $<0.014$ & 0.91 & $<0.029$ & 1.04 & 0.303 & 1.133 & 5.90 & 0.450 & 0.0333 & 0.603 & $<0.014$ & 0.107 \\
\hline \multirow[t]{3}{*}{ TRM572 } & 2010 & FS & 3 & SE & . & . & 0.05 & . & 0.24 & 0.027 & 0.067 & 0.57 & 0.010 & 0.0023 & 0.012 & . & 0.003 \\
\hline & & & & Max & 6.20 & . & 1.00 & . & 1.50 & 0.340 & 1.200 & 6.70 & 0.470 & 0.0370 & 0.620 & . & 0.110 \\
\hline & & & & Mean & $<4.1$ & 0.025 & 0.83 & $<0.03$ & $0.77^{2}$ & 0.313 & 0.807 & 2.07 & 0.353 & 0.0677 & 0.877 & $<0.014$ & 0.102 \\
\hline \multirow[t]{3}{*}{ TRM572 } & 2010 & MI & 3 & SE & . & . & 0.03 & . & 0.02 & 0.012 & 0.019 & 0.03 & 0.015 & 0.0009 & 0.012 & . & 0.004 \\
\hline & & & & Max & . & 0.025 & 0.89 & . & 0.79 & 0.330 & 0.830 & 2.10 & 0.380 & 0.0690 & 0.900 & . & 0.110 \\
\hline & & & & Mean & $7.10^{2}$ & $<0.015$ & 1.30 & $<0.03$ & 1.13 & 0.383 & 1.000 & 2.50 & 0.413 & 0.0540 & 1.167 & $<0.014$ & 0.120 \\
\hline \multirow[t]{3}{*}{ TRM572 } & 2010 & MS & 3 & SE & 0.60 & . & 0.06 & . & 0.09 & 0.019 & 0.055 & 0.20 & 0.019 & 0.0015 & 0.067 & . & 0.010 \\
\hline & & & & Max & 7.70 & . & 1.40 & . & 1.30 & 0.420 & 1.100 & 2.90 & 0.450 & 0.0570 & 1.300 & . & 0.140 \\
\hline & & & & Mean & 2.05 & $<0.024$ & 0.57 & $<0.0041$ & 0.37 & 0.465 & 0.655 & 3.45 & 0.450 & 0.0125 & 0.655 & 0.0275 & 0.205 \\
\hline \multirow[t]{3}{*}{ TRM567 } & 2009 & $\mathrm{FI}$ & 2 & SE & 0.55 & . & 0.03 & . & 0.12 & 0.055 & 0.015 & 0.35 & 0.020 & 0.0005 & 0.005 & 0.0065 & 0.015 \\
\hline & & & & Max & 2.60 & . & 0.60 & . & 0.48 & 0.520 & 0.670 & 3.80 & 0.470 & 0.0130 & 0.660 & 0.0340 & 0.220 \\
\hline & & & & Mean & 5.08 & $<0.019$ & 0.72 & $<0.0033$ & 0.58 & 0.568 & 0.798 & 2.88 & 0.593 & 0.0140 & 0.633 & 0.0325 & 0.170 \\
\hline \multirow[t]{3}{*}{ TRM567 } & 2009 & FS & 4 & SE & 0.70 & . & 0.03 & . & 0.07 & 0.032 & 0.030 & 0.13 & 0.013 & 0.0004 & 0.009 & 0.0031 & 0.017 \\
\hline & & & & Max & 6.10 & . & 0.81 & . & 0.72 & 0.630 & 0.850 & 3.10 & 0.630 & 0.0150 & 0.650 & 0.0410 & 0.220 \\
\hline & & & & Mean & 4.48 & $<0.019$ & 1.09 & $<0.0033$ & 0.56 & 0.685 & 0.653 & 3.08 & 0.395 & 0.0198 & 1.225 & 0.0368 & 0.210 \\
\hline \multirow[t]{2}{*}{ TRM567 } & 2009 & $\mathrm{MI}$ & 4 & SE & 1.10 & . & 0.05 & . & 0.09 & 0.037 & 0.037 & 0.53 & 0.019 & 0.0006 & 0.085 & 0.0009 & 0.031 \\
\hline & & & & Max & 7.60 & . & 1.20 & . & 0.79 & 0.780 & 0.710 & 4.60 & 0.440 & 0.0210 & 1.400 & 0.0380 & 0.280 \\
\hline
\end{tabular}




\begin{tabular}{|c|c|c|c|c|c|c|c|c|c|c|c|c|c|c|c|c|c|}
\hline River/site & Year & $\begin{array}{l}\text { Sex / adult } \\
\text { life stage }\end{array}$ & $\mathrm{N}$ & Statistic & $\mathrm{Al}$ & $\mathrm{Sb}$ & $\mathrm{Ba}$ & $\mathrm{Be}$ & B & $\mathrm{Cd}$ & Co & $\mathrm{Mn}$ & Mo & $\mathrm{Ag}$ & $\mathrm{Sr}$ & $\mathrm{TI}$ & V \\
\hline & & & & Mean & 5.78 & $<0.019$ & 1.21 & $<0.0033$ & 0.81 & 0.595 & 0.803 & 3.28 & 0.560 & 0.0208 & 1.250 & 0.0370 & 0.255 \\
\hline \multirow[t]{3}{*}{ TRM567 } & 2009 & MS & 4 & SE & 0.69 & . & 0.14 & . & 0.14 & 0.032 & 0.024 & 0.65 & 0.006 & 0.0012 & 0.087 & 0.0025 & 0.022 \\
\hline & & & & Max & 7.70 & . & 1.60 & . & 1.20 & 0.680 & 0.870 & 5.20 & 0.570 & 0.0240 & 1.500 & 0.0440 & 0.280 \\
\hline & & & & Mean & $<4.1$ & $<0.019$ & 0.48 & $<0.031$ & $<0.43$ & 0.160 & 0.805 & 4.58 & 0.590 & 0.0076 & 0.583 & $0.0215^{2}$ & 0.092 \\
\hline \multirow[t]{3}{*}{ TRM567 } & 2010 & FS & 6 & SE & . & & 0.03 & . & & 0.012 & 0.023 & 0.24 & 0.018 & 0.0007 & 0.015 & 0.0015 & 0.003 \\
\hline & & & & Max & . & . & 0.56 & . & . & 0.190 & 0.910 & 5.30 & 0.660 & 0.0097 & 0.640 & 0.0230 & 0.098 \\
\hline & & & & Mean & $<4.2$ & $<0.015$ & 0.74 & $<0.031$ & $0.55^{4}$ & 0.330 & 1.008 & 2.12 & 0.367 & 0.0205 & 0.783 & 0.0213 & 0.193 \\
\hline \multirow[t]{3}{*}{ TRM567 } & 2010 & MI & 6 & SE & . & . & 0.02 & . & 0.04 & 0.016 & 0.019 & 0.06 & 0.009 & 0.0009 & 0.019 & 0.0017 & 0.006 \\
\hline & & & & Max & . & . & 0.79 & . & 0.66 & 0.380 & 1.100 & 2.40 & 0.400 & 0.0230 & 0.830 & 0.0290 & 0.210 \\
\hline & & & & Mean & $<0.43$ & $<0.015$ & 0.79 & $<0.036$ & $<0.044$ & 0.243 & 0.955 & 2.00 & 0.548 & 0.0158 & 0.992 & 0.0222 & 0.163 \\
\hline \multirow[t]{3}{*}{ TRM567 } & 2010 & MS & 6 & SE & . & . & 0.02 & . & . & 0.020 & 0.013 & 0.04 & 0.011 & 0.0007 & 0.024 & 0.0023 & 0.004 \\
\hline & & & & Max & . & . & 0.83 & . & . & 0.320 & 0.990 & 2.10 & 0.570 & 0.0180 & 1.100 & 0.0330 & 0.180 \\
\hline & & & & Mean & 3.53 & $<0.019$ & 0.63 & $<0.0033$ & 0.50 & 0.353 & 0.880 & 2.73 & 0.303 & 0.0183 & 0.628 & $<0.015$ & 0.145 \\
\hline \multirow[t]{3}{*}{ TRM563 } & 2009 & MI & 4 & SE & 0.61 & . & 0.07 & . & 0.16 & 0.014 & 0.044 & 0.73 & 0.012 & 0.0005 & 0.051 & . & 0.021 \\
\hline & & & & Max & 5.20 & . & 0.81 & . & 0.97 & 0.380 & 1.000 & 4.90 & 0.320 & 0.0190 & 0.720 & . & 0.180 \\
\hline & & & & Mean & $<3.8$ & $<0.014$ & 0.45 & $<0.028$ & $<0.039$ & 0.230 & 0.817 & 5.27 & 0.490 & 0.0137 & 0.557 & $<0.014$ & 0.113 \\
\hline \multirow[t]{3}{*}{ TRM563 } & 2010 & FS & 3 & SE & . & . & 0.02 & . & . & 0.006 & 0.015 & 0.17 & 0.000 & 0.0009 & 0.009 & . & 0.003 \\
\hline & & & & Max & . & . & 0.49 & . & . & 0.240 & 0.840 & 5.60 & 0.490 & 0.0150 & 0.570 & . & 0.120 \\
\hline & & & & Mean & $<4.0$ & $<0.015$ & 0.73 & $<0.03$ & $<0.42$ & 0.650 & 0.950 & 2.30 & 0.397 & 0.0363 & 0.913 & 0.0173 & 0.203 \\
\hline \multirow[t]{3}{*}{ TRM563 } & 2010 & MI & 3 & SE & . & . & 0.01 & . & . & 0.006 & 0.006 & 0.06 & 0.003 & 0.0003 & 0.038 & 0.0009 & 0.003 \\
\hline & & & & Max & . & . & 0.75 & . & . & 0.660 & 0.960 & 2.40 & 0.400 & 0.0370 & 0.980 & 0.0190 & 0.210 \\
\hline & & & & Mean & $<4.2$ & $<0.015$ & 0.96 & $<0.031$ & 1.08 & 0.390 & 0.930 & 2.23 & 0.520 & 0.0260 & 0.983 & 0.0193 & 0.153 \\
\hline \multirow[t]{2}{*}{ TRM563 } & 2010 & MS & 3 & SE & . & . & 0.01 & . & 0.11 & 0.010 & 0.025 & 0.07 & 0.010 & 0.0006 & 0.012 & 0.0017 & 0.013 \\
\hline & & & & Max & . & . & 0.97 & . & 1.30 & 0.400 & 0.960 & 2.30 & 0.540 & 0.0270 & 1.000 & 0.0210 & 0.180 \\
\hline
\end{tabular}

I "FS" = Female subimago; "FI" = female imago; "MS" = male subimago; "MI" = male imago.

${ }^{2}$ Only 2 replicates had concentrations above the method detection limit; descriptive statistics based on only those 2 replicates.

${ }^{3}$ Only 3 replicates had concentrations above the method detection limit; descriptive statistics based on only those 3 replicates.

${ }^{4}$ Only 4 replicates had concentrations above the method detection limit; descriptive statistics based on only those 4 replicates. 
Table C.3. Mean, standard error of the mean (SE), and maximum (Max) concentrations ( $\mu \mathrm{g} / \mathrm{g}$ dry weight) of major cations and iron (total) in adult mayflies (Hexagenia bilineata) from the Emory

River, Clinch River, and Tennessee River, 2009 and 2010. $\mathrm{N}=$ Number of replicate samples.

Observations with mean and maximum concentrations but no SE indicate that the concentration was below the MDL in all but one replicate.

\begin{tabular}{|c|c|c|c|c|c|c|c|c|c|}
\hline River/site & Year & $\begin{array}{l}\text { Sex / adult } \\
\text { life stage }\end{array}$ & $\mathrm{N}$ & Statistic & $\mathrm{Ca}$ & $\mathrm{Fe}$ & $\mathrm{Mg}$ & $\mathrm{K}$ & $\mathrm{Na}$ \\
\hline \multicolumn{10}{|c|}{ Emory River } \\
\hline & & & & Mean & 816.5 & 258.3 & 805.3 & 12625.0 & 3932.5 \\
\hline \multirow[t]{2}{*}{ ERM4.5 } & 2009 & $\mathrm{MI}$ & 4 & SE & 15.7 & 3.8 & 5.8 & 110.9 & 49.1 \\
\hline & & & & Max & 858.0 & 269.0 & 813.0 & 12900.0 & 4010.0 \\
\hline & & & & Mean & 1700.0 & 115.3 & 2373.3 & 10500.0 & 4090.0 \\
\hline \multirow[t]{3}{*}{ ERM2.8 } & 2010 & $\mathrm{FI}$ & 3 & SE & 41.6 & 0.7 & 52.1 & 208.2 & 5.8 \\
\hline & & & & Max & 1780.0 & 116.0 & 2460.0 & 10800.0 & 4100.0 \\
\hline & & & & Mean & 994.3 & 200.0 & 1170.0 & 13600.0 & 4636.7 \\
\hline \multirow[t]{3}{*}{ ERM2.8 } & 2010 & $\mathrm{MI}$ & 3 & SE & 20.9 & 3.2 & 20.8 & 709.5 & 133.0 \\
\hline & & & & Max & 1020.0 & 205.0 & 1200.0 & 14500.0 & 4890.0 \\
\hline & & & & Mean & 754.0 & 211.0 & 967.5 & 12300.0 & 3860.0 \\
\hline \multirow[t]{3}{*}{ ERM2 } & 2009 & MI & 2 & SE & & 1.0 & 3.5 & 100.0 & 150.0 \\
\hline & & & & Max & 754.0 & 212.0 & 971.0 & 12400.0 & 4010.0 \\
\hline & & & & Mean & 1143.3 & 118.3 & 1906.7 & 9946.7 & 3530.0 \\
\hline \multirow[t]{3}{*}{ ERM2 } & 2010 & $\mathrm{FI}$ & 3 & SE & 27.3 & 2.3 & 20.3 & 103.3 & 5.8 \\
\hline & & & & Max & 1180.0 & 122.0 & 1940.0 & 10100.0 & 3540.0 \\
\hline & & & & Mean & 1190.0 & 110.7 & 1860.0 & 9193.3 & 3676.7 \\
\hline \multirow[t]{3}{*}{ ERM2 } & 2010 & FS & 3 & SE & 30.0 & 5.2 & 50.3 & 299.4 & 33.8 \\
\hline & & & & Max & 1220.0 & 119.0 & 1920.0 & 9560.0 & 3720.0 \\
\hline & & & & Mean & 741.7 & 200.7 & 1005.0 & 11933.3 & 3643.3 \\
\hline \multirow[t]{3}{*}{ ERM2 } & 2010 & MI & 3 & SE & 9.6 & 16.2 & 7.6 & 290.6 & 57.0 \\
\hline & & & & Max & 757.0 & 233.0 & 1020.0 & 12400.0 & 3710.0 \\
\hline & & & & Mean & 882.3 & 171.0 & 1003.7 & 11133.3 & 4596.7 \\
\hline \multirow[t]{3}{*}{ ERM2 } & 2010 & MS & 3 & SE & 18.6 & 3.8 & 28.8 & 66.7 & 61.7 \\
\hline & & & & Max & 919.0 & 178.0 & 1050.0 & 11200.0 & 4720.0 \\
\hline & & & & Mean & 698.0 & 218.0 & 880.0 & 13600.0 & 3795.0 \\
\hline \multirow[t]{3}{*}{ ERM1 } & 2009 & MI & 2 & SE & 33.0 & 1.0 & 5.0 & 0.0 & 25.0 \\
\hline & & & & Max & 731.0 & 219.0 & 885.0 & 13600.0 & 3820.0 \\
\hline & & & & Mean & 1216.7 & 103.3 & 1930.0 & 9353.3 & 3563.3 \\
\hline \multirow[t]{3}{*}{ ERM1 } & 2010 & FS & 3 & SE & 16.7 & 0.7 & 40.4 & 63.9 & 8.8 \\
\hline & & & & Max & 1250.0 & 104.0 & 2010.0 & 9470.0 & 3580.0 \\
\hline & & & & Mean & 710.3 & 194.3 & 941.3 & 12266.7 & 3816.7 \\
\hline \multirow[t]{3}{*}{ ERM1 } & 2010 & $\mathrm{MI}$ & 3 & SE & 20.1 & 0.9 & 8.8 & 120.2 & 37.1 \\
\hline & & & & Max & 742.0 & 196.0 & 959.0 & 12500.0 & 3890.0 \\
\hline & & & & Mean & 955.0 & 160.3 & 1000.3 & 11400.0 & 4640.0 \\
\hline \multirow[t]{3}{*}{ ERM1 } & 2010 & MS & 3 & SE & 20.6 & 0.7 & 11.0 & 57.7 & 85.4 \\
\hline & & & & Max & 996.0 & 161.0 & 1020.0 & 11500.0 & 4740.0 \\
\hline & & & & Mean & 1353.3 & 96.2 & 1786.7 & 9200.0 & 3983.3 \\
\hline \multirow[t]{2}{*}{ ERM0.6 } & 2010 & FS & 3 & SE & 17.6 & 1.4 & 14.5 & 10.0 & 18.6 \\
\hline & & & & Max & 1380.0 & 98.2 & 1810.0 & 9220.0 & 4020.0 \\
\hline ERM0.6 & 2010 & $\mathrm{MI}$ & 3 & Mean & 653.7 & 188.7 & 929.7 & 12300.0 & 3806.7 \\
\hline
\end{tabular}




\begin{tabular}{|c|c|c|c|c|c|c|c|c|c|}
\hline River/site & Year & $\begin{array}{l}\text { Sex / adult } \\
\text { life stage }\end{array}$ & $\mathrm{N}$ & Statistic & $\mathrm{Ca}$ & $\mathrm{Fe}$ & $\mathrm{Mg}$ & $\mathrm{K}$ & $\mathrm{Na}$ \\
\hline & & & & SE & 13.2 & 1.3 & 9.7 & 115.5 & 17.6 \\
\hline & & & & Max & 680.0 & 190.0 & 949.0 & 12500.0 & 3840.0 \\
\hline \multirow{3}{*}{ ERM0.6 } & & & & Mean & 1050.0 & 151.0 & 976.0 & 10966.7 & 4793.3 \\
\hline & 2010 & MS & 3 & SE & 15.3 & 1.0 & 6.1 & 33.3 & 26.7 \\
\hline & & & & Max & 1070.0 & 152.0 & 986.0 & 11000.0 & 4820.0 \\
\hline \multicolumn{10}{|c|}{ Clinch River } \\
\hline \multirow{3}{*}{ CRM6 } & & & & Mean & 1133.3 & 124.0 & 1593.3 & 9620.0 & 4073.3 \\
\hline & 2009 & FS & 3 & SE & 48.4 & 2.5 & 17.6 & 148.0 & 48.4 \\
\hline & & & & Max & 1230.0 & 127.0 & 1620.0 & 9890.0 & 4170.0 \\
\hline \multirow{3}{*}{ CRM6 } & & & & Mean & 951.3 & 170.7 & 1000.7 & 11033.3 & 4610.0 \\
\hline & 2009 & MS & 3 & SE & 60.0 & 3.8 & 14.6 & 33.3 & 79.4 \\
\hline & & & & Max & 1070.0 & 175.0 & 1020.0 & 11100.0 & 4730.0 \\
\hline \multirow{3}{*}{ CRM6 } & & & & Mean & 979.7 & 180.2 & 936.5 & 12216.7 & 4036.7 \\
\hline & 2010 & MI & 6 & SE & 33.9 & 1.1 & 4.5 & 47.7 & 29.1 \\
\hline & & & & Max & 1090.0 & 185.0 & 946.0 & 12400.0 & 4090.0 \\
\hline \multirow{3}{*}{ CRM3.5 } & & & & Mean & 1420.0 & 110.7 & 1916.7 & 10433.3 & 3786.7 \\
\hline & 2010 & $\mathrm{FI}$ & 3 & SE & 37.9 & 2.2 & 18.6 & 145.3 & 38.4 \\
\hline & & & & Max & 1490.0 & 115.0 & 1940.0 & 10700.0 & 3830.0 \\
\hline \multirow{3}{*}{ CRM3.5 } & & & & Mean & 1460.0 & 96.2 & 1783.3 & 9050.0 & 4220.0 \\
\hline & 2010 & FS & 3 & SE & 11.5 & 1.1 & 53.3 & 5.8 & 97.1 \\
\hline & & & & Max & 1480.0 & 98.4 & 1890.0 & 9060.0 & 4350.0 \\
\hline \multirow{3}{*}{ CRM3.5 } & & & & Mean & 1016.7 & 188.0 & 1020.0 & 12900.0 & 4173.3 \\
\hline & 2010 & MI & 3 & SE & 49.1 & 0.6 & 11.5 & 57.7 & 49.8 \\
\hline & & & & Max & 1080.0 & 189.0 & 1040.0 & 13000.0 & 4250.0 \\
\hline \multirow{3}{*}{ CRM1.5 } & & & & Mean & 1270.0 & 83.0 & 1930.0 & 9190.0 & 3420.0 \\
\hline & 2009 & $\mathrm{FI}$ & 1 & SE & & & & & \\
\hline & & & & Max & 1270.0 & 83.0 & 1930.0 & 9190.0 & 3420.0 \\
\hline \multirow{3}{*}{ CRM1.5 } & & & & Mean & 947.0 & 205.7 & 934.7 & 12700.0 & 4186.7 \\
\hline & 2009 & MI & 3 & SE & 75.4 & 13.9 & 20.3 & 251.7 & 94.0 \\
\hline & & & & Max & 1060.0 & 233.0 & 971.0 & 13000.0 & 4300.0 \\
\hline \multirow{3}{*}{ CRM1.5 } & & & & Mean & 1226.7 & 108.3 & 1803.3 & 10233.3 & 3666.7 \\
\hline & 2010 & $\mathrm{FI}$ & 3 & SE & 46.3 & 2.6 & 59.3 & 88.2 & 56.7 \\
\hline & & & & Max & 1310.0 & 113.0 & 1890.0 & 10400.0 & 3780.0 \\
\hline \multirow{3}{*}{ CRM1.5 } & & & & Mean & 905.0 & 172.3 & 1027.7 & 12466.7 & 3906.7 \\
\hline & 2010 & MI & 3 & SE & 77.2 & 3.7 & 17.6 & 185.6 & 88.4 \\
\hline & & & & Max & 1030.0 & 177.0 & 1050.0 & 12700.0 & 4000.0 \\
\hline \multicolumn{10}{|c|}{ Little Emory River } \\
\hline \multirow{3}{*}{ LERM1.0 } & & & & Mean & 1402.5 & 107.3 & 1690.0 & 9825.0 & 4277.5 \\
\hline & 2009 & $\mathrm{FI}$ & 4 & SE & 49.1 & 3.4 & 57.0 & 207.8 & 67.1 \\
\hline & & & & Max & 1480.0 & 116.0 & 1800.0 & 10300.0 & 4400.0 \\
\hline \multirow{3}{*}{ LERM1.0 } & & & & Mean & 1036.5 & 158.3 & 990.8 & 11525.0 & 4375.0 \\
\hline & 2009 & MI & 4 & SE & 64.6 & 1.4 & 13.9 & 154.8 & 56.3 \\
\hline & & & & Max & 1200.0 & 162.0 & 1020.0 & 11800.0 & 4480.0 \\
\hline \multicolumn{10}{|c|}{ Tennessee River } \\
\hline \multirow{3}{*}{ TRM572 } & & & & Mean & 1760.0 & 102.9 & 2216.7 & 10766.7 & 4623.3 \\
\hline & 2010 & FS & 3 & SE & 110.0 & 8.2 & 113.3 & 348.0 & 141.0 \\
\hline & & & & Max & 1870.0 & 119.0 & 2330.0 & 11400.0 & 4820.0 \\
\hline \multirow{2}{*}{ TRM572 } & & & & Mean & 1009.3 & 175.7 & 928.3 & 11833.3 & 4053.3 \\
\hline & 2010 & MI & 3 & SE & 21.3 & 3.3 & 6.6 & 88.2 & 41.8 \\
\hline
\end{tabular}




\begin{tabular}{|c|c|c|c|c|c|c|c|c|c|}
\hline River/site & Year & $\begin{array}{l}\text { Sex / adult } \\
\text { life stage }\end{array}$ & $\mathrm{N}$ & Statistic & $\mathrm{Ca}$ & $\mathrm{Fe}$ & $\mathrm{Mg}$ & $\mathrm{K}$ & $\mathrm{Na}$ \\
\hline & & & & Max & 1050.0 & 182.0 & 941.0 & 12000.0 & 4100.0 \\
\hline & & & & Mean & 1320.0 & 163.3 & 1256.7 & 12600.0 & 5566.7 \\
\hline \multirow[t]{3}{*}{ TRM572 } & 2010 & MS & 3 & $\mathrm{SE}$ & 110.6 & 1.2 & 23.3 & 404.1 & 113.2 \\
\hline & & & & Max & 1540.0 & 165.0 & 1280.0 & 13300.0 & 5750.0 \\
\hline & & & & Mean & 1550.0 & 107.5 & 1980.0 & 8890.0 & 3515.0 \\
\hline \multirow[t]{3}{*}{ TRM567 } & 2009 & $\mathrm{FI}$ & 2 & SE & 60.0 & 0.5 & 10.0 & 20.0 & 35.0 \\
\hline & & & & Max & 1610.0 & 108.0 & 1990.0 & 8910.0 & 3550.0 \\
\hline & & & & Mean & 1232.5 & 123.5 & 1660.0 & 8982.5 & 4247.5 \\
\hline \multirow[t]{3}{*}{ TRM567 } & 2009 & FS & 4 & SE & 43.3 & 2.1 & 43.0 & 56.5 & 44.6 \\
\hline & & & & Max & 1330.0 & 129.0 & 1750.0 & 9120.0 & 4380.0 \\
\hline & & & & Mean & 1033.8 & 174.5 & 1022.5 & 11050.0 & 3567.5 \\
\hline \multirow[t]{3}{*}{ TRM567 } & 2009 & MI & 4 & SE & 71.0 & 2.5 & 10.3 & 64.5 & 63.4 \\
\hline & & & & Max & 1200.0 & 182.0 & 1050.0 & 11200.0 & 3730.0 \\
\hline & & & & Mean & 1150.0 & 171.5 & 1028.8 & 10055.0 & 4815.0 \\
\hline \multirow[t]{2}{*}{ TRM567 } & 2009 & MS & 4 & SE & 7.1 & 1.3 & 39.0 & 59.8 & 20.2 \\
\hline & & & & Max & 1170.0 & 175.0 & 1130.0 & 10200.0 & 4870.0 \\
\hline & & & & Mean & 1376.7 & 81.5 & 1856.7 & 8165.0 & 3418.3 \\
\hline \multirow[t]{2}{*}{ TRM567 } & 2010 & FS & 6 & SE & 23.5 & 1.7 & 22.0 & 58.7 & 57.4 \\
\hline & & & & Max & 1450.0 & 87.6 & 1950.0 & 8320.0 & 3590.0 \\
\hline \multirow{4}{*}{ TRM567 } & & & & Mean & 941.2 & 176.8 & 948.5 & 12233.3 & 3948.3 \\
\hline & 2010 & MI & 6 & SE & 30.8 & 2.0 & 4.6 & 158.5 & 26.6 \\
\hline & & & & Max & 1060.0 & 184.0 & 960.0 & 12800.0 & 4030.0 \\
\hline & & & & Mean & 1081.8 & 146.3 & 987.5 & 10600.0 & 4758.3 \\
\hline \multirow[t]{2}{*}{ TRM567 } & 2010 & MS & 6 & SE & 31.2 & 1.4 & 7.3 & 96.6 & 59.1 \\
\hline & & & & Max & 1200.0 & 150.0 & 1020.0 & 10900.0 & 4950.0 \\
\hline & & & & Mean & 737.3 & 161.5 & 958.3 & 12000.0 & 3350.0 \\
\hline \multirow[t]{3}{*}{ TRM563 } & 2009 & MI & 4 & SE & 40.8 & 2.0 & 9.9 & 81.6 & 39.4 \\
\hline & & & & Max & 807.0 & 167.0 & 982.0 & 12200.0 & 3440.0 \\
\hline & & & & Mean & 1450.0 & 78.2 & 1960.0 & 8383.3 & 3496.7 \\
\hline \multirow[t]{2}{*}{ TRM563 } & 2010 & FS & 3 & SE & 47.3 & 4.5 & 73.7 & 86.5 & 23.3 \\
\hline & & & & Max & 1540.0 & 83.9 & 2100.0 & 8550.0 & 3520.0 \\
\hline \multirow{3}{*}{ TRM563 } & & & & Mean & 1096.7 & 175.7 & 928.0 & 11966.7 & 3800.0 \\
\hline & 2010 & MI & 3 & $\mathrm{SE}$ & 20.3 & 0.7 & 0.6 & 218.6 & 32.1 \\
\hline & & & & Max & 1130.0 & 177.0 & 929.0 & 12400.0 & 3850.0 \\
\hline \multirow{3}{*}{ TRM563 } & & & & Mean & 1160.0 & 146.3 & 943.7 & 10433.3 & 4793.3 \\
\hline & 2010 & MS & 3 & SE & 45.8 & 2.2 & 3.0 & 417.7 & 29.1 \\
\hline & & & & Max & 1250.0 & 149.0 & 948.0 & 10900.0 & 4840.0 \\
\hline
\end{tabular}

I "FS" = Female subimago; "FI" = female imago; "MS" = male subimago; "MI" = male imago. 